\title{
UMA ANÁLISE DE INSUMO-PRODUTO DA ECONOMIA BRASILEIRA NO PERÍODO DE TRANSIÇÃO(1990-1994) PARA A FORMAÇÃO DO MERCOSUL
}

\section{REGINA CELIA FARIA SIMÕES}

Economista

Orientador: Prof. Dr. JOAQUIM JOSÉ MARTINS GUILHOTO

Tese apresentada à Escola Superior de Agricultura "Luiz de Queiroz", Universidade de São Paulo, para obtenção do Título de Doutor em Ciências, Área de Concentração: Economia Aplicada.

PIRACICABA

Estado de São Paulo - Brasil

Janeiro - 1998 


\section{Dados Internacionais de Catalogaçāo na Publicaçāo (CIP) DIVISĀO DE BIBLIOTECA E DOCUMENTAÇĀO - Campus "Luiz de Queiroz"/USP}

Simōes, Regina Celia Faria

Uma análise de insumo-produto da economia brasileira no periodo de transição (1990-1994) para a formação do MERCOSUL / Regina Celia Faria Simōes. - Piracicaba, 1998.

$198 \mathrm{p}$.

Tese (doutorado) - - Escola Superior de Agricultura Luiz de Queiroz, 1998.

Bibliografia.

1. Economia aplicada 2. Integração econômica 3. MERCOSUL 4. Relaçāo insumo-produto I. Título 


\section{UMA ANÁLISE DE INSUMO-PRODUTO DA ECONOMIA BRASILEIRA NO PERÍODO DE TRANSIÇÃO (1990-1994) PARA A FORMAÇÃO DO MERCOSUL}

REGINA CELIA FARIA SIMÕES

Aprovada em: 30.04 .1998

Comissão julgadora:

Prof. Dr. Joaquim Bento de Souza Ferreira Filho

ESALQ/USP

Profa. Dra. Heloísa Lee Burquist ESALQ/USP

Prof. Dr. Pedro Ramos UNICAMP

Profa. Dra . Angela Maria Cassavia Jorge Corrêa UNIMEP

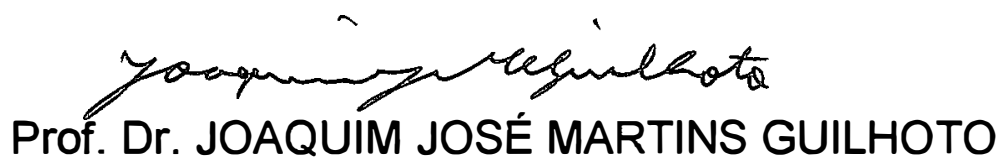

Orientador 
Aos meus pais, Manoel e Cely, aos meus filhos Thiago, Rafael e Leandro, ao Fábio, uma pessoa especial, dedico. 


\section{AGRADECIMENTOS}

Gostaria de deixar aqui minha gratidão pelas contribuições que recebi.

Ao Departamento de Economia da ESALQ/USP, por tudo que aprendi.

À CAPES, pelo apoio financeiro.

Ao Professor Joaquim José Martins Guilhoto, pela inteligente orientação e pelo apoio dado nas horas mais difíceis que enfrentei.

Aos membros da banca examinadora, Professor Joaquim Bento de Souza Ferreira Filho, Professora Heloísa Lee Burnquist, Professora Angela Corrêa e Professor Pedro Ramos.

Aos amigos, Júnior, Claudinei, Maura, Cristina, Flávia, Sebastião, Ricardo, Patrícia, Cecília, Matilde, Valdir, Valéria e Solange pela ajuda valiosa.

Aos meus colegas de curso pelas interessantes discussões e pelos bons momentos que passamos.

À minha família, aos meus filhos Thiago (em especial), Rafael e Leandro e ao Fábio Chagas Orsi pela compreensão.

A Deus pela oportunidade que me deu de chegar até aqui, pois sem Ele não conseguiria nada. 


\section{SUMÁRIO}

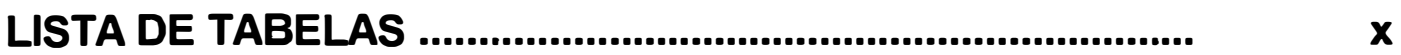

LISTA DE FIGURAS ........................................................... xi

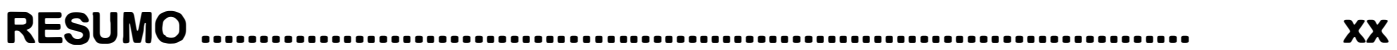

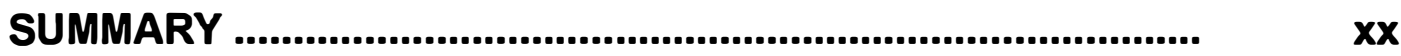

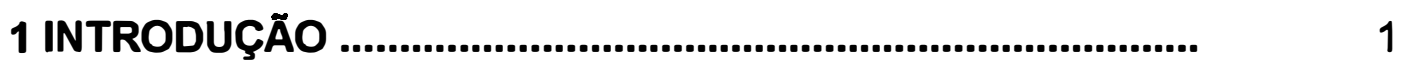

1.1 Considerações Iniciais ......................................................

1.2 O Problema e sua Importância .......................................... 2

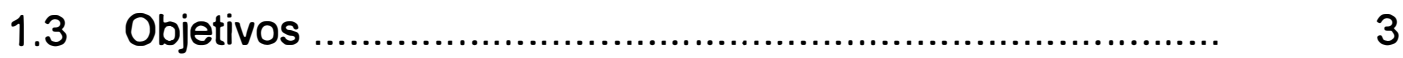

1.4 Integração: Conceitos e Definições ..................................

1.5 Teorias da Integração ...................................................... 8

2 A INTEGRAÇÃO ECONÔMICA NA AMÉRICA LATINA ............ 18

2.1 A CEPAL e a Integração Econômica ................................ 19

2.2 Movimentos de Integração na América Latina ...................... 23

2.3 A ALALC e a ALADI ....................................................... 25

2.4 A Integração Econômica nos anos oitenta e noventa .......... 34

2.5 MERCOSUL - Mercado Comum do Sul ............................ 37 
2.5.1 O Periodo de Transição ..................................................... 41

2.5.2 A Estrutura do MERCOSUL ......................................... 41

2.5.3 Regime Geral de Origem ..............................................

2.5.4 Soluçāo de Controvérsias ................................................ 45

2.5.5 Cláusula de Salvaguarda .............................................. 46

2.5.6 A Tarifa Externa Comum - TEC ....................................... 46

2.6 O MERCOSUL e as Novas Parcerias ................................ 47

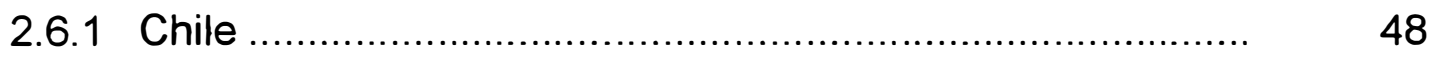

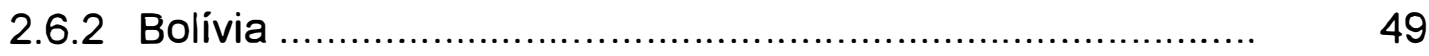

2.6.3 Reflexos da Entrada do Chile e Bolivia no MERCOSUL ...... 50

2.6.4 Área de Livre Comércio das Américas - ALCA ................... 50

3 CARACTERISTICAS DOS PAÍSES DO MERCOSUL ................. 52

3.1 Perfil dos Paises do MERCOSUL ..................................... 52

3.2 Desempenho do Brasil no Comércio Internacional .............. 54

3.3 A Economia dos paises do MERCOSUL ............................ 63

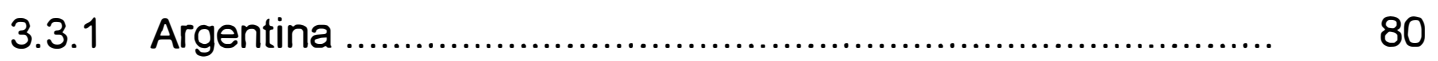

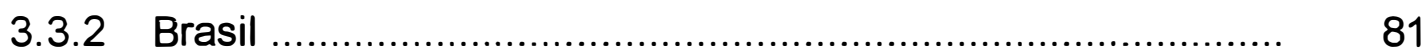

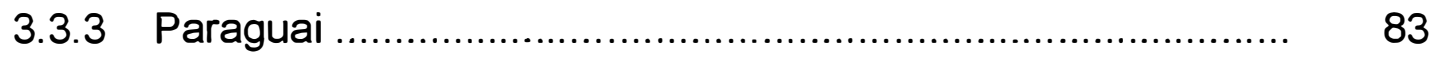

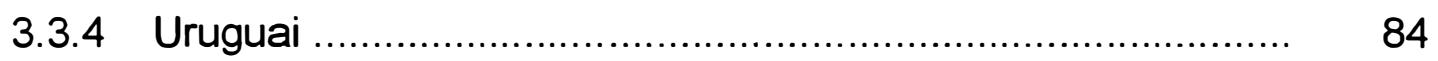

4 REFERENCIAL TEÓRICO E FONTE DOS DADOS ....................... 86

4.1 Introdução …........................................................... 86

$4.2 \quad$ Referencial Teórico .......................................................... 92

4.2.1 Representação Algébrica do Miodelo .................................. 92

4.2.2 Representação Matricial do Modelo .................................... 93

4.2.3 Multiplicadores............................................................... 95 
4.3 Índices de Ligação para frente e para trás ............................ 95

4.4 İndice Puro de Ligações Interindustriais ............................ 98

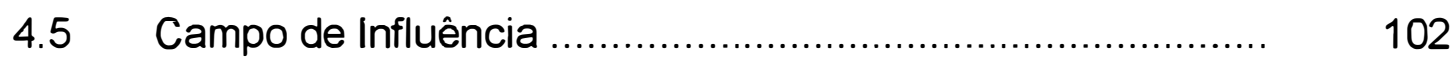

4.6 Apresentação das Fontes e Tratamento dos Dados ........... 104

5 RESULTADOS E DISCUSSÕES ............................................. 110

5.1 Mudanças Estruturais .................................................. 110

5.1.1 Estrutura Produtiva......................................................... 110

5.1.2 Estrutura da Demanda Final ........................................ 114

5.1.3 Tecnologia da Produção . . ................................................ 117

5.2 Multiplicadores Setoriais de Produto.................................. 119

5.3 Índices de Ligações Interindustriais .................................. 135

5.3.1 İndices de ligações para trás ............................................. 135

5.3.2 Índices de ligações para frente ........................................ 139

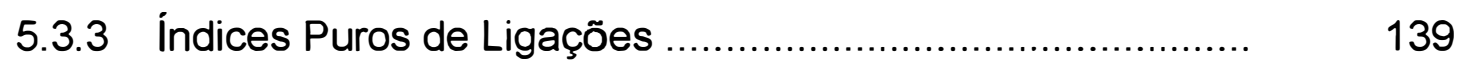

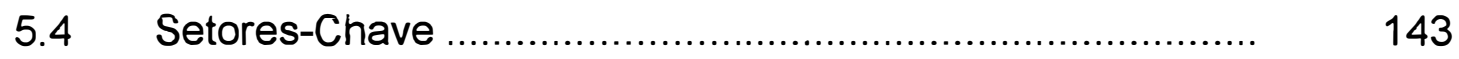

5.5 Campo de Influência ....................................................... 145

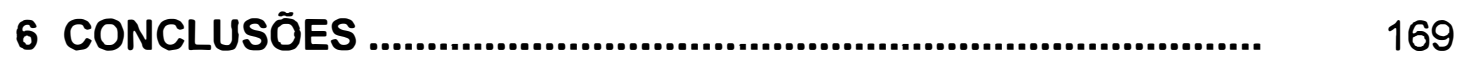

REFERÊNCIAS BIBLIOGRÁFICAS .......................................... 173

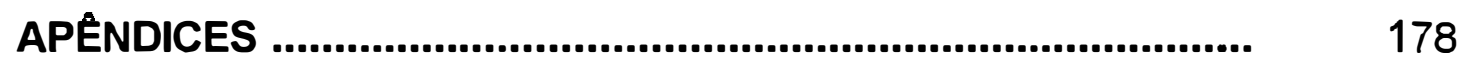




\section{LISTA DE TABELAS}

Tabelas $n .^{\circ}$

Página

3.1

MERCOSUL - Dados Gerais - 1995

52

3.2 Brasil - Intercâmbio Comercial - Totais Gerais (US\$ Milhões) FOB.

55

3.3 Brasil - Exportações Totais por Blocos - US\$ milhões/FOB

3.4 Brasil - Importações do Brasil por Blocos de Origem (US\$/FOB)

3.5 Brasil: Exportação por Fator Agregado US\$ milhões/FOB

3.6 Brasil: Exportações e Importações - Bloco Europeu

3.7 Brasil: Exportações e Importações - Bloco América do Norte.

3.8 Brasil: Exportações e Importações - Bloco Asiático

3.9 Brasil: Exportações e Importações - Bloco América do Sul....

3.10 Brasil: Exportações e Importações - Bloco MERCOSUL. 
3.12 Exportações Brasileiras para os países do MERCOSUL, Chile, Bolívia - 1990-1996 (US\$ milhões-FOB).

Importações Brasileiras para os países do MERCOSUL, Chile, Bolívia - 1990-1996 US\$ milhões-FOB).

3.14 Exportações Brasileiras para a Argentina 1990-1996 - US\$ milhões - FOB

Exportações Brasileiras para o Paraguai 1990-1996 - US\$ milhões - FOB

Exportações Brasileiras para o Uruguai 1990-1996 - US\$ milhões - FOB

3.17 Exportações Brasileiras para o Chile 1990-1996 - US\$ milhões - FOB

3.18 Exportações Brasileiras para a Bolivia 1990-1996 - US\$ milhões - FOB

3.19 Exportações Brasileiras para o Resto do Mundo - 1990-1996 - US\$ milhões - FOB .

3.20 Importações Brasileiras da Argentina 1990-1996 - US\$ milhões - FOB

3.21 Importações Brasileiras do Paraguai 1990-1996 - US\$ milhões - FOB

3.22 Importações Brasileiras do Uruguai 1990-1996 - US\$ milhões - FOB

3.23 Importações Brasileiras do Chile - 19901996 - US $\$$ milhões - FOB

3.24 Importações Brasileiras da Bolívia - 19901996 - US\$ milhões - FOB

3.25 Importações Brasileiras do Resto do Mundo 1190-1996 - US\$ milhões - FOB 
3.26 Principais Parceiros Comerciais - Argentina 80

3.27 Principais Parceiros Comerciais - Brasil ...... 82

3.28 Principais Parceiros Comerciais - Paraguai . 84

3.29 Principais Parceiros Comerciais - Uruguai ... 85

4.1 Setores do Modelo ….................................. 108

5.1 Valor Adicionado (\%) - 1990-1994 ............... 112

5.2 Estrutura Produtiva (\%) $-1990-1994 \ldots \ldots \ldots \ldots \ldots . . .113$

5.3 Participação da Demanda Final na Produção Total (\%) - 1990-1994 ............................... 115

5.4 Participação das Exportações Brasileiras na Produção Total (\%) - 1990-1994 .................... 116

5.5 Participação dos Insumos Importados do Mercosul na Produção Total (\%) - 1990-1994 . 118

5.6 Multiplicador de Produto por ramo da atividade econômica - Brasil - 1990-1994 .......

5.7 Multiplicador de Produto - Argentina 1990-1994

5.8 Multiplicador de Produto - Paraguai 1990-1994

5.9 Multiplicador de Produto - Uruguai 1990-1994

$5.10 \quad$ Multiplicador de Produto - Chile-1990-1994 ...

5.11 Multiplicador de Produto-Bolívia-1990-1994 ..

5.12 Multiplicador de Produto=Resto do Mundo 1990-1994

5.13 Impactos-Consumo das Famílias/Demanda Final - 1990-1994 
5.14 Impactos-Consumo do Governo/Demanda

Final - 1990 - 1994

5.15 Impactos-Formação Bruta de Capital/

Demanda Final - 1990-1994

Impactos-Variação de Estoque/Demanda

Final - 1990-1994

5.17 Impactos-Exportações Totais Brasileiras/

Demanda Final - 1990-1994

Impactos Exportações para a Argentina/

Exportações Totais - 1990-1994

Impactos Exportações para o Paraguai/

Expoprtações Totais - 1990-1994

5.20 Impactos Exportações para o Uruguai/

Exportações Totais - 1990-1994

5.21 Impactos Exportações para o Chile/

Exportações Totais - 1990 - 1994

Participação (\%) dos Produtos Importados em Relação ao Consumo das Famílias (F) 1990 1994

5.23 Participação (\%) dos Produtos Importados em Relação à Formação Bruta de Capital (K) 1990-1994

5.24 Índice de ligações para trás de Rasmussen/ Hirschman - Brasil - 1990--1994

5.25 Índice de ligações para frente de Rasmussen/ Hirschman - Brasil - 1990-1994

5.26 Dispersão do índice de ligações para trás de Rasmussen/Hirschman - Brasil - 1990-1994 ....

5.27 Dispersão do índice de ligações para frente de Rasmussem/Hirschman - Brasil-1990-1994 . 
5.28 Índice puro de ligações para trás - Brasil

1990-1994

5.29 Índice puro de ligações para frente-Brasil

1990-1994 


\section{LISTA DE FIGURAS}

Figura . $^{\circ}$

Página

2.1 A Estrutura do MERCOSUL ….................... 43

3.1 Exportações Brasileiras Totais, Importações Brasileiras Totais e saldo (US\$ milhões - FOB) 1980-1996

3.2 Exportações Brasileiras para os países do Mercosul, Chile e Bolivia (US \$ milhões - FOB) 1990-1996

66

3.3 Importações Brasileiras para os países do Mercosul, Chile e Bolivia (US\$ milhões - FOB) 1990-1996

3.4 Exportações Brasileiras e Importações Brasileiras no período de 1990-1996

- Argentina -

3.5 Exportações Brasileiras e Importações Brasileiras no período de 1990-1996

- Paraguai -

3.6 Exportações Brasileiras e Importações Brasileiras no período de 1990-1996 - Uruguai -

3.7 Exportações Brasileiras e Importações Brasileiras no período de 1990-1996

- Chile - 
3.8 Exportações Brasileiras e Importações

Brasileiras no período de 1990-1996

- Bolivia -

3.9 Exportações Brasileiras e Importações Brasileiras no periodo de 1990-1996

- Resto do Mundo -

4.1 Estrutura das Matrizes de Insumo-

Produto Utilizada no Modelo

109

5.1 Índice de ligação para trás-1990 ............. 146

5.2 Índice de ligação para trás-1991 ............. 146

5.3 Índice de ligação para trás-1992 ............ 147

5.4 Índice de ligação para trás $-1993 \ldots \ldots \ldots \ldots . .147$

5.5 Índice de ligação para trás - $1994 \ldots \ldots \ldots \ldots . .148$

5.6 Índice de ligação para frente $-1990 \ldots \ldots . . .148$

5.7 Índice de ligação para frente - $1991 \ldots \ldots . . .149$

5.8 Índice de ligação para frente $-1992 \ldots \ldots .$.

5.9 Índice de ligação para frente $-1993 \ldots \ldots . . .150$

5.10 Índice de ligação para frente $-1994 \ldots \ldots .$.

5.11 Dispersão Rasmussen/Hirschman-1990 . 151

5.12 Dispersão Rasmussen/Hirschman-1991 . 151

5.13 Dispersão Rasmussem/Hirschman-1992 152

5.14 Dispersão Rasmussen/Hirschman-1993 . 152

5.15 Dispersão Rasmussen/Hirschman-1994 . 153

5.16 Dispersão para frente Rasmussen/

Hirschman - 1990 
5.17 Dispersão para frente Rasmussen/ Hirschman - 1991 ...................................

5.18 Dispersão para frente Rasmussen/ Hirschman - 1992

5.19 Dispersão para frente Rasmussen/ Hirschman - 1993

5.20 Dispersão para frente Rasmussen/ Hirschman - 1994

5.21 Índice puro de ligações para trás-1990 .... 156

5.22 Índice puro de ligações para trás-1991 ....

5.23 Índice puro de ligações para trás-1992 ....

5.24 Índice puro de ligações para trás-1993 ....

5.25 Índice puro de ligações para trás-1994 ....

5.26 Índice puro de ligações para frente-1990 .

5.27 Índice puro de ligações para frente-1991.

5.28 Índice puro de ligações para frente-1992 .

5.29 Índice puro de ligações para frente-1993 .

5.30 Índice puro de ligações para frente-1994 .

5.31 Índice puro-total de ligação - 1990

161

5.32 Índice puro-total de ligação - 1991

5.33 Índice puro-total de ligação - 1992 ............ 162

5.34 Índice puro=total de ligação $-1993 \ldots \ldots \ldots \ldots . . .162$

5.35 Índice puro-total de ligação - $1994 \ldots \ldots \ldots \ldots . . .163$

5.36 Coeficientes com maior Campo de Influência - 1990 
5.37 Coeficientes com maior Campo de

Influência - 1991.

5.38 Coeficientes com maior Campo de

Influência - 1992

166

5.39 Coeficientes com maior Campo de

Influência - 1993

167

5.40 Coeficientes com maior Campo de

Influência - 1994

168 


\section{UMA ANÁLISE DE INSUMO-PRODUTO DA ECONOMIA BRASILEIRA NO PERÍODO DE TRANSIÇÃO (1990-1994) PARA A FORMAÇÃO DO MERCOSUL}

Autora: Regina Celia Faria Simões

Orientador: Joaquim José Martins Guilhoto

\section{Resumo}

Este trabalho tem por objetivo analisar os impactos da formação do Mercado Comum do Sul (MERCOSUL) sobre a economia brasileira. Mais especificamente, pretende-se verificar os efeitos da criação do MERCOSUL sobre o comércio externo brasileiro, a estrutura produtiva brasileira e sobre a demanda final, levando-se em conta seus componentes, ou seja, formação bruta de capital, gastos do governo, consumo das famílias e exportações.

Utilizou-se o modelo de insumo-produto para detectar os reflexos do MERCOSUL sobre a economia brasileira. Além disso, foram usados outros conceitos a saber: Multiplicadores Setoriais, Índices de Ligação para frente e para trás, Índices Puros, Setores-Chave e o conceito de Campo de Influência para mostrar os impactos da criação do MERCOSUL em 21 setores da economia brasileira.

Os resultados evidenciaram que o comércio externo brasileiro apresentou crescimento rigoroso no período analisado mas, a estrutura produtiva brasileira não apresentou mudanças significativas. Com relação ao comportamento da demanda final, apenas o consumo das familias apresentou pequenas modificações. 


\section{An ANALYSIS OF INPUT-OUTPUT OF THE BRAZILIAN ECONOMY IN THE PERIOD OF TRANSITION (1990-1994) FOR THE FORMATION OF MERCOSUL}

Author: Regina Celia Faria Simões

Adviser: Joaquim José Martins Guilhoto

\section{Summary}

The goal of this study is to analyze the impacts of the formation of the Common Market of South America (MERCOSUL) on the Brazilian economy. More specifically, the effects of MERCOSUL on the Brazilian external commerce, on the Brazilian productive structure, and on the final demand are verified considering their components, that is, the gross capital formation, government expenditures, family consumption, and exports.

The input-output model was used to detect the influences of MERCOSUL on the Brazilian economy. In addition, other concepts were used such as sectorial multipliers, backward and forward linkage indexes, pure indexes, key-sectors and field of influence approach to show the impacts of the creation of MERCOSUL on 21 sectors of the Brazilian economy.

The results showed evidences that the Brazilian external commerce had an extreme growth during the analyzed period, although the Brazilian productive structure failed to present significant changes. in regard to the behavior of the final demand, only the family consumption had a few modifications. 


\section{INTRODUÇÃO}

\subsection{Considerações iniciais}

As profundas transformações do cenário mundial ocorridas nos últimos 30 anos reservaram ao mundo mudanças significativas nos campos social, político e econômico. Vários acontecimentos marcaram mais profundamente este período, entre eles a formação e consolidação de blocos econômicos, cujos efeitos são enfocados por este trabalho.

Esta nova ordem mundial é um desafio que a América Latina tem que enfrentar. Já Balassa (1961) explicitava a motivação da integração econômica decorrente de intervenção estatal nas economias nacionais e da restrição ao comércio, dada a necessidade de diminuir as flutuações e promover o crescimento dos povos. "No que diz respeito aos países subdesenvolvidos, o crescimento econômico surge como consideração primordial. Os países que seguem os conselhos dos defensores da doutrina do crescimento econômico equilibrado podem procurar a integração econômica a fim de assegurar um mercado suficientemente vasto para o desenvolvimento paralelo de novas indústrias".

Dessa forma, em março de 1991 foi assinado o Tratado de Assunção pelos governos do Brasil, da Argentina, do Paraguai e do Uruguai. Neste tratado, prevê-se como objetivo final a criação do Mercado Comum do Sul (MERCOSUL) como um mercado comum integrado pelos quatro países. 
Enquanto projeto integracionista o MERCOSUL prevê a livre circulação de bens, serviços, capitais e pessoas dentro dos limites dos quatro países envolvidos no projeto e, paralelamente, o estabelecimento de barreiras comuns perante o resto do mundo no que se refere a aspectos tais como normas de controle de qualidade, certificados de origem, nível das alíquotas de importações, etc. (Hirst, 1992, Jank, 1992).

A formação do MERCOSUL é uma estratégia de desenvolvimento dos países latinos frente à nova conjuntura internacional. É sem dúvida uma tentativa ambiciosa de constituir um espaço econômico comum que permita conjugar esforços e assegurar uma inserção mais competitiva dos países membros em terceiros mercados.

\subsection{O problema e sua importância}

O processo de instabilidade e inflação vivido pela economia brasileira nas duas últimas décadas foi bastante grave no sentido de desestruturar a capacidade dos setores produtivos.

De uma das economias mais fechadas durante quatro décadas de protecionismo, a economia brasileira passa a ser uma das mais abertas do mundo, através das políticas de liberalização comercial que vêm sendo implantadas a partir de meados da década de 80 , mais notadamente nos anos 90 .

Por outro lado, a organização dos países em blocos regionais reforça a condição de hegemonia dos países desenvolvidos com maior capacidade científica e tecnológica. Esse contexto apresenta-nos o acirramento competitivo do mercado, exigindo a modernização e a reestruturação dos setores produtivos nacionais.

Além disso, a teoria da integração econômica argumenta que qualquer processo integracionista provocará mudanças na estrutura produtiva e no comércio dos paísesmembros. 
Portanto, a partir da criação do MERCOSUL, que mudanças ocorreram na estrutura produtiva da economia brasileira? Quais os impactos causados na demanda final? Como os diferentes setores estão se comportando frente ao MERCOSUL?

Parece oportuno tentar encontrar respostas, como pretende esta pesquisa, para as questões levantadas anteriormente, no periodo chamado de "periodo de transição", ou seja, no periodo 1990-94. É importante ressaltar que a partir da consolidação do MERCOSUL, ou seja, a médio e longo prazos, o processo do MERCOSUL deverá alterar essa estrutura de forma mais significativa.

As mudanças efetuadas por qualquer um dos paises-membros desse processo integracionista com relação à condução de sua política doméstica refletirá de maneira mais direta nas economias dos outros paises, tendo em vista as disparidades existentes entre os mesmos.

Face à implantação do MERCOSUL, tem-se procurado avaliar em vários aspectos as consequências que o mesmo acarretará para as economias dos paises participantes do Acordo. Vários estudos discutem as perspectivas do setor agricola, setor este considerado o mais sensivel frente a esse processo integracionista e que deverá arcar com o ônus maior da integração (Perez, 1988; Jank, 1992; Lopes, 1992; Stulp, 1992).

A validade desse estudo é indiscutivel para subsidiar estudos posteriores que permitirão avaliar os efeitos do MERCOSUL a partir da sua consolidação.

\subsection{Objetivos}

Este trabalho tem por objetivo geral apresentar uma análise de insumo-produto da economia brasileira no periodo de transição (1990-1994) para a formação do MERCOSUL. Especificamente, para atingir esse objetivo pretende-se: 
a) caracterizar o comércio brasileiro junto aos países-membros no sentido de identificar os principais setores e as possiveis mudanças na estrutura desse comércio;

b) verificar os impactos da criação do MERCOSUL sobre os componentes da demanda final setorial (consumo das famílias, gastos do governo e investimentos) que provocarão mudanças no valor da produção setorial;

c) fazer uma análise da evolução da estrutura produtiva da economia brasileira no período 1990-1994, através do uso de algumas informações básicas contidas nas tabelas de insumo-produto e através dos Multiplicadores Setoriais de Produto, Índices de ligações para trás e para frente, visando a determinação de setores-chave, dos Índices Puros e do Conceito de Campos de Influência, sobre os setores a serem definidos a partir deste trabalho;

\subsection{Integração: conceitos e definições}

Em comércio internacional, um programa de integração econômica pode ser definido como um conjunto de acordos, convênios, normas, regulamentações, entre outros, estabelecidos entre dois ou mais paises, com o intuito de promover 0 desenvolvimento conjunto de suas respectivas economias, a partir do aproveitamento das vantagens econômicas oferecidas por acordos comerciais, por acordos setoriais de produção, pela eliminação de barreiras comerciais, pelo incremento do intercâmbio de mercadorias e fatores de produção e pela harmonização de políticas econômicas nacionais e internacionais.

Várias definições têm sido formuladas sobre integração. Para Balassa (1961), integração econômica é o processo ou estado de coisas pelas quais diferentes nações decidem formar um bloco regional. Ainda, o autor considera que a integração se dá em diferentes dimensões: integração comercial, integração setorial, integração em nível 
dos fatores, integração em nível de política, integração total. As definições de integração podem ser econômicas ou podem priorizar os aspectos políticos envolvidos.

Baumann \& Lerda (1987, p.13) consideram que "o termo integração é reservado para caracterizar um processo político entre governos nacionais, visando reduzir parcial ou totalmente as barreiras (tarifárias ou não-tarifárias) que limitam o comércio recíproco. Tal processo pode ou não incluir acordos relativos às barreiras dos países signatários em relação ao resto do mundo, e o âmbito da integração pode ser bilateral ou multilateral, incluindo apenas uma parte ou a totalidade dos bens potencialmente transacionáveis entre os membros da Comunidade".

Já Cohen (1981) citado por Perez (1988) define integração como sendo um processo mediante o qual dois ou mais paises adotam, com o apoio das instituições comuns, medidas conjuntas para aprofundar a sua interdependência e obter assim benefícios mútuos.

A integração econômica pode assumir várias formas diferenciadas conforme a abrangência das normas e dos acordos entre os países. Balassa (1961), Baumann \& Lerda (1987) e Machado (1991), mostram as diferenças existentes nos vários estágios de integração, até chegar à sua plenitude.

Um processo de integração pode se iniciar com a formação de uma Zona de Livre Comércio, passando por uma União Aduaneira e Mercado Comum, até chegar ao estágio mais avançado de integração, ou seja, uma União Monetária ou Econômica.

A primeira etapa de um processo de integração seria a instalação de uma Zona de Livre Comércio, que consiste em uma celebração de acordo, onde são eliminadas todas as tarifas entre os países membros, embora cada qual mantenha suas tarifas em relação aos países não membros.

Os países interessados negociam entre si a criação de uma zona onde os bens podem circular livremente, sem a existência de barreiras tarifárias e de barreiras técnicas (padrões diferentes), de saúde (controles sanitários), fiscais (impostos ou 
taxas discriminatórios) e físicas (controle das fronteiras). Para se impedir que outros países fora da zona se beneficiem do acordo, é criado um instrumento importante de comércio chamado regras de origem, que determina a procedência dos bens que poderão se beneficiar das preferências negociadas.

A segunda etapa seria uma Zona de Livre Comércio mais uma tarifa externa comum, o que convencionamos chamar de União Aduaneira, sendo esta uma forma mais avançada de integração. Tanto as Uniões Aduaneiras como as Zonas de Livre Comércio têm uma tarifa nula entre os sócios. A diferença entre ambas está na adoção de uma estrutura uniforme de barreiras tarifárias em relação ao resto do mundo. Neste estágio de integração é indispensável um mínimo de harmonização das políticas fiscal, monetária e cambial entre os diversos membros do bloco, para que não se impeça o andamento do processo, pois essa etapa é difícil pelo fato de gerar zonas de conflito (Veiga, 1991).

$\mathrm{Na}$ terceira etapa, Mercado Comum, atinge-se uma forma mais elevada de integração econômica, em que são abolidas não só as restrições comerciais, mas, também, as restrições aos movimentos de fatores produtivos. Tal negociação exige a criação de instituições supranacionais que determinam a legislação do mercado comum, além de políticas comuns acima das políticas nacionais. Mais ainda, implica a coordenação e harmonização da legislação fiscal, trabalhista e de sociedades.

O estágio superior de um processo integracionista, a União Monetária ou Econômica, é a quarta etapa, que é definida a partir de um Mercado Comum cujos membros decidem adotar políticas uniformes com respeito à moeda, crédito, impostos, entre outros.

Na síntese de Montoya (1993, p. 136) "um esquema de integração, qualquer que seja a forma adotada, inicia-se com a implementação de mecanismos destinados a eliminar a discriminação ao comércio intra-regional, enquanto se estabelecem tarifas externas contra terceiros países. Fica definido, assim, um só espaço econômico, no 
qual se possibilita o aproveitamento das vantagens comparativas e as economias de escala que um mercado ampliado permite".

Como exemplos atuais de zona de livre comércio temos a European Free Trade Association (EFTA) entre os países nórdicos e transalpinos e o North American Free Trade Agreement (NAFTA) entre os Estados Unidos, Canadá e México. Fazem parte deste exemplo ainda a Área de Livre Comércio Sul Americana (ALCSA) cuja formação - Brasil vem liderando e o Asian Free Trade Agreement (AFTA) recém criado pelos países do sudeste asiático.

São exemplos de união aduaneira a então Comunidade Econômica Européia (CCE) na sua fase inicial e o estágio atual da integração do MERCOSUL que, apesar de imperfeita, já definiu uma Tarifa Externa Comum (TEC) para cerca de $85 \%$ do universo dos produtos classificados na nomenclatura comum do MERCOSUL.

A CEE até 1994, reforçada com a criação do programa do mercado interno que procurou destruir as barreiras físicas, técnicas e fiscais que impediam que o mercado comum pleno funcionasse entre os seus doze membros, é um exemplo de mercado comum. Outro exemplo é o MERCOSUL, que, como o próprio nome diz, tem por objetivo a formação de um mercado comum.

O Tratado de Maastrich que criou a União Européia em substituição à CEE e que deverá ser implantada até 1999 é um exemplo de processo de criação de uma união econômica. Cabe ressaltar que a integração leva cada país a renunciar, parcialmente, ao controle de sua política econômica e, consequentemente, a uma parcela de sua soberania. Com o aumento da interdependência entre países ocorre um inevitável debilitamento das soberanias nacional, econômica e política. Para recuperar graus de soberania e influência internacional é preciso avançar coletivamente na formação de mercados comuns (Ibarra, 1991). 


\subsection{Teorias da integração}

As primeiras contribuições a respeito da teoria da integração econômica encontram-se nas obras dos economistas clássicos. Adam Smith diz:

"Quando uma nação se obriga por um tratado a permitir a entrada de certos produtos de um país estrangeiro, enquanto proibe essa entrada quando os mesmos são oriundos dos demais, ou quando isenta de direitos os produtos de um país, que os demais países são obrigados a pagar, o país ou pelo menos os comerciantes e fabricantes desse país, cujo comércio é tão favorecido, devem necessariamente tirar grandes vantagens desse tratado. Esses comerciantes e fabricantes gozam de uma espécie de monopólio no país que é tão indulgente para com eles. Esse país se transforma em um mercado mais amplo e vantajoso para os seus produtos..." (Smith, 1776, citado por Ricardo, 1817, p. 230).

David Ricardo no início do século XIX já mencionava a existência de vantagens comparativas como um motivo para que o livre comércio gerasse um ganho em termos de eficiência alocativa aos países. No entanto, não é apenas uma maior eficiência alocativa que parece motivar o livre comércio, ganhos em termos de extensão de mercado, exploração de ganhos de escala, aumento da competitividade e um maior incentivo a busca do progresso tecnológico seriam também outras consequências do livre comércio.

Analisando os tratados comerciais do ponto de vista do país importador, Ricardo diz:

"O inconveniente do tratado para o país importador seria o seguinte: obrigaria a França, por exemplo, a comprar produtos na Inglaterra pelo preço natural, quando poderia talvez comprá-los por um preço natural muito mais baixo em outro país. $\mathrm{O}$ tratado provoca, portanto, uma desvantajosa distribuição do capital geral, que reflete principalmente no país que é obrigado pelo mesmo a comprar no mercado menos 
produtivo.... Em que consistem então as vantagens do estabelecimento desse tratado? Consistem no seguinte: esses produtos não poderiam ser fabricados na Inglaterra para exportação, se esse país não gozasse do privilégio de abastecer com exclusividade o mercado em questão; porque a concorrência de um país onde o preço natural fosse mais baixo eliminaria para a Inglaterra qualquer possibilidade de vender essas mercadorias". (Ricardo, 1817, p. 231).

A primeira referência explícita a um processo de integração mais ambicioso parece datar de 1840, quando o economista alemão Friedrich List argumenta, em seu tratado "Das nationale system der politischen ôkonomie", que o desenvolvimento econômico de uma nação depende da posse de um território adequado, e aponta a associação de estados baseada em acordos bilaterais voluntários - especialmente uniões alfandegárias - como a melhor forma de corrigir eventuais inadequações territoriais.

Mas é através da publicação de Viner (1950) "The customs union issue" que a teoria da integração econômica ganha consistência. Preocupado com os problemas envolvidos na criação de uniões aduaneiras, seu modelo apresenta os efeitos da formação de uma união alfandegária, através dos conceitos de "criação de comércio" e "desvio de comércio". Haverá criação de comércio quando, dada a eliminação das barreiras comerciais entre dois países, um deles deixa de produzir internamente determinado bem, passando a importá-lo do outro, em decorrência do menor custo de produção deste e, consequentemente, do seu menor preço; e haverá desvio de comércio quando um determinado membro da união alfandegária passe a importar certo bem do outro membro, deixando de comprá-lo de um terceiro país, de fora da união, que antes constituía a fonte de oferta mais barata; nesse caso, ocorre desvio de comércio, pois a oferta proveniente de um país menos eficiente na produção do bem em questão aumenta relativamente à oferta de um produtor mais eficiente.

Quando existe criação de comércio significa que o país substituiu sua oferta interna, que era cara, por importações mais baratas do parceiro comercial, o que produz um ganho de bem-estar. Quando o que ocorre é desvio de comércio significa, 
que o país substituiu importações mais baratas do resto do mundo por importações caras de seu novo parceiro comercial, o que é uma desvantagem, não havendo nenhum ganho de bem-estar. Do ponto de vista do livre comércio, a "criação de comércio" é benéfica, e o "desvio de comércio" é prejudicial.

Muitos trabalhos surgiram baseados na obra de Viner (1950) incorporando várias contribuições, uma vez que a sua análise restringia-se ao lado da produção. Mas, no final da década de 70 , surge a nova teoria do comércio internacional, caracterizada por hipóteses de mercados imperfeitamente competitivos e retornos crescentes de escala, permitindo incorporar à análise dos problemas do comércio internacional aspectos da realidade brasileira (economias de escala, diferenciação de produtos, firmas com poder de mercado, entre outros).

As primeiras tentativas de integração na América Latina a partir da década de 60 sofreram influência tanto da teoria tradicional da integração, como da teoria cepalina do desenvolvimento econômico, que propunha a integração econômica como instrumento capaz de reduzir os desequilibrios produzidos pela industrialização periférica com base na substituição de importações. A teoria tradicional do comércio, também chamada de teoria dos acordos preferenciais de comércio ou ainda, teoria da união aduaneira, sustentou vários projetos de integração e, ainda hoje, a influência dessa teoria se faz presente nas posições do GATT e do Banco Mundial.

Os efeitos positivos e negativos da integração econômica foram analisados por vários autores. Balassa (1961) considera como a integração econômica contribui para o bem-estar, utilizando o conceito de bem-estar potencial, num sentido estático, onde um aumento nesta variável seria equivalente a uma melhor distribuição dos recursos. Mas o autor não limita sua investigação a hipótese estática e analisa o efeito da integração na eficiência dinâmica. Ele define a "eficiência dinâmica como a taxa de crescimento hipotética do rendimento nacional que se pode obter com uma dada utilização dos recursos (materiais e trabalho) e um dado coeficiente de poupança" (Balassa p. 28-29). E a partir desta definição compara a taxa de crescimento hipotética que se pode atingir antes e depois da integração. Assim, um aumento da taxa de 
crescimento seria equivalente a uma maior eficiência dinâmica e representaria um acréscimo do bem-estar potencial.

Para Thorstensen et alii (1994, p.41), os ganhos estáticos surgem com a remoção de barreiras e sua consequente incrementação do comércio, ampliando o mercado para as empresas, com efeitos positivos sobre a alocação de recursos dos paises membros. As principais fontes de ganhos estáticos são: "aumento de eficiência na produção devido ao aumento na especialização e utilização de insumos e bens de capital especializados; aumento no nivel de produção devido ao aproveitamento das economias de escala com o acesso a um mercado mais amplo; melhoria no poder de barganha internacional, devido ao tamanho maior do mercado, levando a melhores termos de troca; mudanças forçadas na eficiência econômica (custos menores, maior nível de emprego, maiores salários) trazidas pela competição maior; mudanças que afetam o volume e a qualidade dos fatores de produção devido ao progresso tecnológico" (El-Agraa, 1985, p. 184-185).

Os efeitos dinâmicos de comércio derivam do aumento da taxa de crescimento da economia que o incremento de comércio com redução de barreiras traz: "economias de escala tornadas possíveis pelo acesso a mercados mais amplos; economias externas às firmas, que podem reduzir os custos específicos ou gerais; aumento na taxa de investimento devido ao aumento de fluxo de capital do exterior; efeito polarização, devido à concentração do efeito de criação de comércio ou desenvolvendo tendência a atrair fatores de produção de outras regiões; efeito da eficiência econômica e da confiança devido ao aumento de competição e redução de incerteza" (El-Agraa, 1985, p. 192).

Para Ffrench-Davis (1978, p. 265), os efeitos distributivos da integração econômica são: a integração econômica altera a estrutura do comércio exterior e da produção de todos os países-membros e condiciona a forma e o nivel de desenvolvimento que cada país pode atingir; influi no tipo de distribuição de benefícios entre a região integrada e o resto do mundo, dependendo do investimento estrangeiro e afeta de forma diferenciada as diversas regiões e os diferentes grupos sociais. 
Entre os efeitos positivos da formação das uniões aduaneiras, podemos destacar: (a) a diminuição das distorções de consumo; (b) o surgimento de economias de escala, devido à ampliação do espaço econômico e, (c) a melhora dos termos de intercâmbio. Todos esses efeitos da formação de uma união aduaneira, tanto para os países membros quanto para terceiros, são condicionados pelos níveis que venha a assumir a Tarifa Externa Comum (TEC) da região.

No caso de uma união aduaneira, quanto mais elevada a TEC, maior será o nivel de proteção à produção interna da região integrada e maior a probalidade de que, num primeiro momento, os preços domésticos sejam mais elevados que os preços internacionais e, portanto, mais elevado o preço para consumidores e produtores dentro da região.

Se a tarifa externa comum é muito baixa, não se deve esperar um crescimento acentuado do comércio intra-regional, pois a produção doméstica não estará suficientemente protegida em relação a terceiros países, e aumentarão as dificuldades para uma reestruturação da produção regional que permita aproveitar as oportunidades de um mercado ampliado.

A TEC determinará, portanto, até o ponto em que a integração econômica abrirá novos mercados para os produtores regionais dentro da própria região e em que medida melhorarão os termos de intercâmbio dos produtos regionais. Faz-se evidente, assim, a relevância do estabelecimento da TEC tanto para o relacionamento comercial intra-regional quanto para o intercâmbio com o resto do mundo. A TEC ocasiona mudanças nos padrões de comércio exterior. As mudanças nos fluxos de comércio recíproco produzem alterações na composição da demanda efetiva e tendem a afetar a estrutura produtiva.

Ainda, a teoria da integração econômica ressalta que o consumo será afetado com a consequente substituição de bens produzidos interna $e$ externamente por mercadorias dos países participantes, o que modificará a estrutura da produção e o fluxo de comércio. Estas alterações nas razões de troca 
implicarão numa redistribuição do rendimento real dos países participantes e não participantes, afetando o bem-estar mundial.

De fato, o MERCOSUL, que na realidade é um grande desafio de integração econômica assumido entre Brasil, Argentina, Paraguai e Uruguai, efetivamente implantado no dia $1^{\circ}$ de janeiro de 1995 , já produziu impactos consideráveis em relação ao padrão de comércio regional. As exportações brasileiras para os países do MERCOSUL somaram, em 1990, US\$1.330 milhões/FOB, passando, em 1996, para US $\$ 7.299$ milhões/FOB, apresentando nesse período um crescimento de $448,8 \%$, aproximadamente. Em relação às importações brasileiras dos países do MERCOSUL, verifica-se um crescimento de $254,9 \%$, ou seja, em 1990 , as importações brasileiras foram da ordem de US\$2.326 milhões/FOB, passando para US\$8.256 milhões/FOB, em 1996. (Secretaria do Comércio Exterior - SECEX).

Mas para que a integração econômica ocorra é necessário a resolução dos problemas de distribuição dos recursos, crescimento e políticas econômicas, dadas as diferentes dimensões de mercado.

A integração da economia como um todo exigiria nas palavras de Balassa ( $p$. 32), "uma atividade concentrada em todo o campo da atividade econômica, desde a abolição de barreiras à coordenação das políticas fiscais".

A formação de blocos regionais para os países em desenvolvimento, que não conseguem garantir de certa forma a estabilidade política, pode ser de grande importância na medida que romper acordos internacionais é muito mais difícil do que mudar políticas internas, tornando irreversíveis as reformas e acrescentando um elemento de estabilidade das políticas desses países.

A integração em blocos regionais, liderados por países desenvolvidos, como é o caso do NAFTA, pode promover a reestruturação econômica contornando a fragilidade do sistema político, deixando as próprias pressões do mercado mundial globalizado promoverem as reformas, removendo os obstáculos para que aquelas tendências 
transformadoras do mercado possam atuar. As resistências políticas serão menores uma vez iniciadas as transformações mais profundas na estrutura da sociedade, agora com novo paradigma tecnológico e penetradas pelas forças globalizadoras.

Balassa descreve ainda outra maneira de se chegar à integração econômica fazendo-a setor por setor, integrando várias indústrias sucessivamente. $\mathrm{O}$ argumento era que seria mais fácil um governo se comprometer limitadamente com um setor do que com todos os setores ao mesmo tempo. Esperava-se com isso que a integração em um setor encorajasse a integração em maior escala.

Enquanto a integração simultânea de todos os setores permite alterações compensatórias, num processo mais suave de ajustamento dos preços relativos e de redistribuição dos recursos, além de facilitar a manutenção do equilíbrio externo, no método setorial, como coloca Balassa (p. 32), "cada passo na integração resulta num equilíbrio novo e temporário de preços, custos e distribuição de recursos e este "equilíbrio" é perturbado em cada fase seguinte", além ainda de causar pressões na balança de pagamentos.

Para Baumann \& Lerda (1987, p.24-25), entre as condições básicas para viabilizar um processo de integração, "destaca-se a adoção de um conceito amplo de reciprocidade, envolvendo uma convergência de políticas referentes a balanço de pagamentos e estratégia de crescimento, o que implica em consequências para a definição das políticas fiscal, de investimento e de desenvolvimento regional, entre outras".

"Em segundo lugar - talvez mais importante a curto prazo - é necessário que sejam definidas as bases para um tratamento comum em relação ao capital estrangeiro. A premência desta definição se explica pelo atrativo que representa a constituição de um mercado amplo como o que resultará da integração". (Baumann \& Lerda, 1987, p. 25). 
Ibarra (1991, p. 200) coloca que "a formação das zonas de livre comércio e depois a industrialização conjunta, criariam novos focos de desenvolvimento capazes de atenuar as pressões de pagamentos por seus efeitos na criação e desvio de comércio. Isso mesmo fortaleceria o poder externo de negociação, entretanto o aproveitamento das economias de escala e das associadas à articulação interindustrial melhoraria a eficiência comparativa frente ao exterior e permitiria abordar depois os mercados de terceiros países".

No caso da América Latina, "a abertura sem integração cancelaria boa parte das potenciais economias de complementaridade e debilitaria permanentemente o poder latino-americano de negociação em um mundo transnacionalizado e dividido em grandes regiões econômicas. Em contraste, a integração permitiria aliviar em algum grau as crescentes restrições externas que afrontam os países latino-americanos e ganhar experiências incalculáveis no processo de remodelação das articulações com terceiros países". (Ibarra, p. 210).

Com a integração econômica, as uniões aduaneiras podem forçar as indústrias mais conservadoras a aperfeiçoarem suas técnicas de produção e comércio, a fim de que se mantenham no ramo. Assim haverá ganhos na poupança de recursos produtivos e na capacidade de gerenciamento empresarial.

Por outro lado, com o aumento das dimensões do mercado haverá um aumento da demanda. Considerando então que as empresas trabalham a pleno emprego ou sem "capacidade ociosa", elas podem aumentar o tamanho de suas fábricas mais rapidamente gerando economias de escala. Com a integração econômica, portanto, existirão mais ganhos acelerados na tecnologia e investimento. Para que esses ganhos se concretizem é preciso considerar a localização geográfica do mercado e seu custo de transporte o que poderá eliminar as vantagens comparativas existentes.

"Por último, qualquer que for a natureza dos efeitos estáticos e dinâmicos da integração, a concepção dos "custos e benefícios" da teoria, em seu avanço, sugerem, na realidade, uma redistribuição de recursos entre as indústrias existentes, utilizando 
os suprimentos de fatores e a tecnologia disponivel. Assim, algumas indústrias se expandem, outras se contraem, enquanto os consumidores gozam de preços mais baixos para determinados produtos; caso contrário, tudo continuaria como antes". (Montoya, p. 144).

"Países a caminho da industrialização geralmente querem estabelecer indústrias nascentes: seu objetivo ao formarem um mercado comum ou uma área de livre comércio é ter um mercado maior que lhes permita estabelecer e fazer expandir indústrias nascentes mais depressa elou de modo mais barato que o que seria possível de outra forma. Outro nome para o estabelecimento de sua própria indústria nascente seria destruição de comércio - o oposto de criação de comércio". (Willianson, 1989, p.92).

Wonnacott e Wonnacott (1981, in Dornbusch, p. 19) argumentam corretamente que "os ganhos por maior acesso aos mercados não se baseiam rigorosamente em um acesso preferencial. Eles se fundamentam no acesso, mas a proximidade geográfica, e portanto o menor custo de transporte que no resto do mundo, podem proporcionar a países associados uma renda natural derivada do acesso aos mercados".

Os países participantes de uma união aduaneira podem diminuir seus custos de produção industrial entre os membros de diferentes maneiras: vantagens comparativas regionais ou dentro da união, economias de escala na produção, aumento da diversidade para os consumidores, além de um incremento na competitividade.

Segundo Machado (1993), o êxito dos esforços de integração no MERCOSUL dependerá fundamentalmente da superação de dois obstáculos, sendo um deles "vencer as resistências nacionais ao estabelecimento de uma tarifa externa comum, criando as condições para a geração permanente de vantagens comparativas na região".

O MERCOSUL apresenta uma diferença qualitativa importante em relação aos processos anteriores de integração na América Latina. No MERCOSUL os países 
membros desejam promover, simultaneamente, a integração sub-regional e a maior inserção na economia mundial. Em primeiro lugar, porque este processo de abertura para o exterior já se havia iniciado, a nível de cada país, antes mesmo do Tratado de Assunção, ainda que com ritmos diferentes. Ademais, levou-se em conta o fracasso dos esquemas anteriores de integração.

No próximo capítulo mostram-se os antecedentes que levaram à criação do MERCOSUL onde a idéia principal é avaliar em que medida o projeto de integração contido no Tratado de Assunção representa um marco que o diferencia das tentativas anteriores de integração. 


\section{A INTEGRAÇÃO ECONÔMICA NA AMÉRICA LATINA}

A experiência de integração na América Latina possui uma tradição de mais de um século, seja como um movimento social na busca de afirmar sua cultura, seja como uma estratégia de desenvolvimento econômico, ou mais recentemente como uma exigência da globalização econômica mundial. Na América Latina, a exemplo da Europa, a idéia de integração é um velho sonho. A integração oferecia a possibilidade de ampliar o mercado.

Silva (1990, p.34) relata que as primeiras idéias integracionistas na América Latina nasceram na fase de luta pela independência política dos países da região no século XVIII. A maior expressão desse ideal foi Simon Bolivar. Assinaram o Tratado de União, Liga e Confederação Perpétua em 26 de julho de 1826 no Congresso de Panamá, as Repúblicas da Colômbia, Centro América, Peru, Estados Unidos e México, e pela Organização da Grã-Colômbia, que buscava a união em uma só república a Colômbia, Venezuela, Equador e Peru.

Simon Bolivar acreditava em uma América hispânica e portuguesa por extensão independente de qualquer domínio exterior. Afirmava constantemente sobre a unidade Latino Americana que "era uma idéia grandiosa pretender formar de todo o Novo Mundo uma só nação, com um só vínculo que ligasse suas partes entre si e com o todo. Já que tem uma origem, uma lingua, os mesmos costumes e uma região, deveria, por conseguinte, ter um só governo que confederasse os diferentes Estados que 
venham a formar-se". (Ezcurra, 1988). O mesmo anseio de unificação ou de confederação estava no espírito de San Martin.

\subsection{A CEPAL e a integração econômica}

A Comissão Econômica para a América Latina (CEPAL) foi criada em 28 de fevereiro de 1948, constituindo-se um ramo regional do Conselho Econômico e Social das Nações Unidas. Constituiu, na verdade, o primeiro esforço integrado na procura de soluções estruturais para os males econômicos e sociais que, no final da década de 50, já afligiam a América Latina.

Desde logo enfatizou-se a necessidade da integração econômica da América Latina: ela foi afirmada em nível técnico, claramente, no chamado "Manifesto" da CEPAL, elaborado em 1949 e publicado em 1950 pelas Nações Unidas com o título "El desarrollo econômico de América Latina y sus principales problemas". A CEPAL teve, de fato, atuação decisiva nas iniciativas de integração regional, como a criação da Associação Latino-Americana de Livre Comércio (ALALC) em 1960 com o Tratado de Montevidéu, o Mercado Comum Centro-Americano (MCCA) em 1961, e o Pacto Andino em 1969.

A secretaria executiva da CEPAL criou em 1957 o "Grupo de Trabalho de Mercado Regional Latino Americano" e o "Comitê de Comércio", com a finalidade de promover a integração regional bem como acelerar as primeiras definições de uma fórmula que deflagrasse esse processo. Na sua primeira reunião de consulta, em 1958, ativou estudos e propôs a criação de Mercado Comum Latino-Americano para liberalização progressiva do comércio recíproco. A secretaria executiva da CEPAL cujo presidente era Raul Prebisch, preparou o documento "O Mercado Comum Latino Americano", publicado em junho de 1959, com o objetivo de apoiar as negociações a 
criarem uma instituição que gerasse um processo de integração econômica no continente, nos moldes de um Mercado Comum.

O documento sintetiza claramente a estratégia de desenvolvimento que deveria ser implementada na região, a partir da perspectiva de um Mercado Comum Latino Americano. Defendia a tese de que o problema econômico fundamental da região residia em alcançar uma taxa satisfatória de crescimento sustentado, que the permitia diminuir progressivamente as diferenças de renda e dependência com os grandes centros industriais do mundo (CEPAL, 1990, p.142).

O funcionamento do Mercado Comum como estratégia de desenvolvimento econômico, deveria ajudar a consolidar a industrialização, além de reduzir a vulnerabilidade econômica da região com o exterior. Frente à lentidão da expansão das exportações tradicionais, a industrialização era concebida como um meio imprescindível para acelerar o desenvolvimento. A indústria deveria não só substituir importações de bens manufaturados como, também, incrementar na medida do possível as exportações não tradicionais. A integração econômica através da intensificação do comércio intra-regional permitiria uma substituição muito mais eficiente, através da especialização e economias de escala que o mercado ampliado permite (Salgado, 1990, p.117).

A escola cepalina criou o conceito de deterioração dos termos de intercâmbio dos produtos primários, defendendo modelos nacionais baseados na substituição de importações, forma obrigatória da industrialização no processo de desenvolvimento das economias periféricas, na industrialização protegida, e com ênfase na necessidade de ampliação dos mercados limitados pelo estabelecimento de mercado comum latinoamericano, trazendo essa industrialização substitutiva a tendência inerente ao desequilíbrio externo. Identificam-se, quanto à tecnologia, dois aspectos: a inadequação da densidade de capital e a inadequação da escala. É neste segundo aspecto que entra o papel da integração. Segundo a análise de Rodriguez (1981, p. 161), "a inadequação da escala em relação ao tamanho de cada um dos mercados periféricos gera um alto grau de subutilização de capital, com a industrialização sendo 
levada a cabo em compartimentos estanques. A integração e a especialização industrial das diversas economias da área representam, por outro lado, uma possibilidade concreta de reduzir de forma considerável essas grandes margens de capacidade ociosa".

Na visão da CEPAL, os benefícios da integração estão vinculados à redução dessas margens de capacidade ociosa, com pelo menos três efeitos: alívio da tensão do balanço de pagamentos, dado o melhor aproveitamento das divisas destinadas à aquisição de equipamentos importados; industrialização mais eficiente com consequente maior taxa global de crescimento e maior volume de comércio com o resto do mundo; possibilidade de exportar manufaturas para o resto do mundo, dado o aumento da eficiência industrial.

Além disso, a redução das margens de capacidade ociosa afeta a produtividade do capital e, ao elevar a taxa de acumulação, afeta favoravelmente o crescimento.

Cabe mencionar aqui que a teoria econômica tradicional enfatiza os efeitos da integração sobre o emprego dos recursos de forma estática, e a CEPAL ressalta esses efeitos sobre a dinâmica do desenvolvimento periférico, considerando a integração mais do que uma forma de melhor alocar os recursos - como um instrumento eficaz para reduzir as tensões e desequilíbrios próprios do desenvolvimento para dentro. No dizer de Rodriguez (1981, p. 162), "no pensamento da CEPAL, a integração regional é uma conclusão de política econômica coerentemente ligada ao conjunto de contribuições teóricas que constituem a interpretação da industrialização periférica".

As tentativas de integração na América Latina foram avaliadas por Thoumi (1989) através da elaboração de um estudo econométrico dos fluxos de comércio bilateral na América Latina e Caribe, para explorar a estrutura do comércio intraregional na América Latina e Caribe, identificando as características que certos tipos de integração teriam mais chance de sucesso que outros. Os sistemas de integração entre países não muito distantes, de tamanho e nível de desenvolvimento similares, e 
que perseguem políticas econômicas semelhantes, têm mais chance de sucesso que outros sistemas (Thoumi, p. 427).

Embora por vezes haja um superdimensionamento da necessidade de integração, elevada quase à categoria de única solução eficaz, o raciocínio básico é relativamente simples e poderia ser assim esquematizado: as economias de escala exigem grandes volumes de produção que por sua vez requerem uma grande demanda consumidora; dado que nos países latino-americanos a demanda é insuficiente (mercados limitados), a solução imediata é a integração dos mercados.

Resumidamente, as teses mais importantes da CEPAL, sobre a integração do mercado regional, nas décadas de 50 e 60 são apresentadas por Salgado (1979, p.8992):

a) a CEPAL reconhecia que o objetivo de longo prazo deveria ser a formação de um mercado comum latino-americano, mas que esse objetivo somente poderia ser alcançado avançando aos poucos, por etapas, levando em consideração as condições particulares dos países e a flexibilidade dos instrumentos utilizados. A proposta inicial da CEPAL apoiava, basicamente, uma área de tarifas preferenciais que, no prazo de 10 anos, conseguisse uma redução substancial do nível médio das tarifas alfandegárias. A liberalização plena do comércio e a elaboração de uma tarifa externa comum ficariam para uma segunda etapa;

b) a insistência num processo gradualista decorre da ambição de que o mercado regional deveria ter a suficiente flexibilidade para facilitar a incorporação de todos os países da América Latina;

c) desde o início, a CEPAL insistiu na incorporação de um tratamento preferencial relativo para os países de menor desenvolvimento relativo (PMDR) e para os intermediários, para evitar a concentração dos benefícios nos países mais evoluídos. Para isso, a CEPAL propunha dois tipos de medidas: o princípio da 
reciprocidade no comércio intra-regional e o tratamento diferenciado segundo o grau de desenvolvimento dos países-membros;

d) no caso da ALALC, a posição da CEPAL era a de aceitar a função do mecanismo de mercado na alocação de recursos, principalmente cedendo às pressões dos países maiores. No MCCA, as condições foram mais propícias para recomendar uma distribuição deliberada de certas indústrias, ou seja, uma espécie de programação industrial;

e) a CEPAL aceitava suas exceções importantes à cláusula de nação mais favorecida (também utilizada pelo GATT - Acordo Geral de Tarifas e Comércio, que determina uma concessão outorgada a outro país participante do mesmo acordo de integração ou a um terceiro país deve, automaticamente, ser estendida a todos os países-membros): o tratamento preferencial para os PMDR e os acordos de complementação. Estes últimos tinham como objetivo o desenvolvimento das novas indústrias de integração ou a racionalização de indústrias já existentes. A CEPAL achava que esses acordos de especialização e complementação estariam entre os instrumentos mais eficazes para o desenvolvimento da indústria integrada. É por isso que se justificava que fossem excluídos da cláusula de nação mais favorecida. Essa posição da CEPAL contrariava as concepções mais difundidas sobre a integração com base na teoria tradicional.

\subsection{Movimentos de integração na América Latina}

Ao final da década de 40 a idéia de estabelecer um mercado comum latinoamericano passa a receber apoio crescente. A CEPAL (para quem, como vimos, a integração permitiria a ampliação de mercados, com a consequente elevação de produtividade via economias de escala, o que viabilizaria assim a industrialização substitutiva de importações e a superação do subdesenvolvimento) tem influência 
marcante nos movimentos integracionistas da região, que buscavam a ampliação do comércio intra-regional.

Deste modo, já na década de 50, a integração econômica da América Latina era vista como um caminho à industrialização bem como uma forma de isolar a América Latina da instabilidade do setor externo da região, instabilidade decorrente das oscilações dos preços dos bens primários de exportação no mercado internacional.

"De acordo com a interpretação da CEPAL, o processo de desenvolvimento das economias latino-americanas havia chegado, na segunda metade dos anos 50, a um impasse, provocado pelas perspectivas de contração da capacidade de importar da região (...), extremamente dependentes da importação de máquinas, equipamentos e tecnologia dos paises industrialmente desenvolvidos: a capacidade de importar surgia então como um importante fator limitativo ao crescimento". (Versiani, 1987, p.27).

O comércio intra-regional, entretanto, sofreu um declínio na década de 50 , comenta Ffrench-Davis (1982, p. 119), de forma que o restabelecimento dos fluxos comerciais prévios, agora sobre uma base distinta e mais estável, se transformou em um dos principais objetivos dos esforços integracionistas. Em 1959, a Argentina, o Brasil, o Chile e o Uruguai pretendiam formar uma zona de livre comércio.

Assim é que surgem vários movimentos de integração na América Latina, a partir da década de 60: o Tratado Geral de Integração Centro-Americana, instrumento normativo básico do Mercado Comum Centro-Americano (MCCA), com Costa Rica, EI Salvador, Guatemala e Nicarágua, assinado em dezembro de 1960, e, entrando em vigor em junho de 1961; Associação Latino-Americana de Livre Comércio (ALALC), com Argentina, Bolívia, Brasil, Chile, Colômbia, Equador, México, Paraguai, Peru, Uruguai e Venezuela criada em 1960 pelo Tratado de Montevidéu, em junho de 1965. As nações do Caribe (Antígua, Barbados, Guiana, Jamaica, Trinidade-Tobago e sete territórios) assinaram o Tratado de Dickenson Bay, pelo qual se estabeleceu a Associação Caribenha de Livre Comércio (CARIFTA); em 1969 foi firmado o Pacto Andino (com Chile, Bolívia, Colômbia, Equador, Peru e Venezuela) visando intensificar 
a integração através de um mercado comum andino; em 1973, o Tratado de Chaguaramas substituiu a CARIFTA pela Comunidade do Caribe e pelo Mercado Comum do Caribe (CARICOM); e, em 1980, substituindo a ALALC, é criada através do Tratado de Montevidéu a Associação Latino-Americana de Integração (ALADI). Todos esses processos de integração estão em andamento, atualmente. Soma-se a esses processos a iniciativa de formar um grupo sub-regional, ou seja, o MERCOSUL constituído por Brasil, Argentina, Paraguai e Uruguai, criado em 1991.

Esses sistemas variaram substancialmente no grau de redução das barreiras comerciais internas, estabelecimento de tarifas externas e promoção da industrialização regional. Todos eles enfrentaram as expectativas que foram injustificadamente depositadas sobre eles. Particularmente a partir do segundo choque do petróleo, associado ao choque dos juros internacionais em 1979, a fragilidade externa da América Latina impõe graves restrições a esses esquemas integracionistas. De fato, com o agravante da crise da dívida externa que eclode em 1982 com a moratória mexicana, o comércio intra-regional sofre uma redução dramática na década de 80 , colocando em xeque o futuro da integração regional.

\subsection{A ALALC e a ALADI}

Dentro do contexto de formação de blocos, aumenta a necessidade dos países ditos periféricos de assumirem posições concretas, para acompanharem as tendências e não mais ficarem às margens do desenvolvimento dos países centrais. Neste sentido, já em meados da década de cinquenta, iniciou-se um concreto movimento para a criação de uma Associação de Livre Comércio na América Latina.

Em fevereiro de 1960 é assinado o Tratado de Montevidéu, dando origem à ALALC, cujo objetivo era a constituição, no prazo de doze anos de um mercado comum regional para a eliminação gradual de barreiras ao intercâmbio intrazonal, estimulando 
o fortalecimento das economias nacionais e a racionalização da produção e do comércio exterior. Concordando com as idéias da CEPAL, tem objetivo de menor alcance, dado a alta coordenação de políticas nacionais exigidas pelas propostas amplas da CEPAL e, dado aos maus olhos com que o Fundo Monetário Internacional (FMI) via o desvio de comércio para a região.

Um movimento que inicialmente (1956 a 1959) obteve um caráter sub-regional, que previa a liberalização do comércio na área do Brasil, Chile, Uruguai e Argentina, tornou-se mais amplo com a adesão, em 1959, da Bolívia, do Paraguai e do Peru. Em 1960 foi a vez do México, em 1961, do Equador, em 1966, da Venezuela e, finalmente, em 1967 foi a vez da Bolívia.

Ante os inconvenientes e as dificuldades que representaria uma liberalização imediata e automática do comércio dentro da região, o tratado previa uma fórmula moderada de atuação através de negociações periódicas de produto por produto entre as partes. A partir destas negociações seriam formadas as Listas Nacionais e as Listas Comuns, que não tiveram bons resultados, e também o Conselho de Ministros de Relações Exteriores da ALALC (Silva, 1990).

A ALALC dispunha de dois mecanismos principais para promover a integração: acordos complementares e um programa de liberalização. Os acordos complementares visavam a desenvolver diferentes sub-ramos ou estágios de produção de novas indústrias nos países que voluntariamente participassem de cada acordo. Quando a produção se iniciava, estes produtores recebiam preferências tarifárias previstas no acordo. O programa de liberalização baseava-se em negociações país a país, onde preferências tarifárias eram intercambiadas.

A mecânica da liberalização da ALALC consistia de redução das barreiras alfandegárias através de dois instrumentos básicos. O primeiro eram as Listas Nacionais, em que cada país arrolava produtos concedendo $8 \%$ anuais de redução nas importações da área, sob a forma de concessões revogáveis. O segundo instrumento eram as Listas Comuns, elaboradas a cada três anos em termos de concessões 
irrevogáveis. Uma característica importante desses mecanismos é que as concessões feitas a um país eram automaticamente estendidas a todos os demais paises da ALALC, isto é, adotava-se a cláusula de Nação Mais Favorecida incondicional a nível regional.

Os resultados da ALALC, segundo análise de Versiani (in Baumann e Lerda, 1987 , p. 26-42), indicam que o ímpeto inicial era apenas aparente. Em 1969 as concessões das Listas Nacionais tornam-se inexpressivas, e já em 1967 a segunda negociação trienal da Lista Comum não chega a um consenso. $O$ instrumento básico passa a ser os acordos de complementação, que abrangiam determinados setores industriais, proporcionando concessões tarifárias para estímulo de sua expansão, porém revogando-se o princípio de multilateralismo, isto é, de extensão automática de concessões a todos os países membros. Há de se destacar, entretanto, que estes acordos concentraram-se nos países grandes, tendo participação decisiva das multinacionais.

O prazo de eliminação total das barreiras comerciais é estendido de 1972 para 1980, através do Protocolo de Caracas de 1969, começando a reconhecer-se o limitado sucesso da ALALC.

De 1960 a 1980 há um crescimento contínuo e lento do comércio intra-regional, talvez não tanto devido aos acordos integracionistas, mas sim em função do crescimento (ao menos até 1973) dos países industrializados, que elevou o comércio internacional.

Até o final de sua primeira década de existência (1970), a ALALC funcionou com resultados positivos chegando mesmo a criar-se sistema de compensação de pagamentos entre os países-membros (1965). Mas, apresentou resultados limitados, com um problema grave de distribuição de seus benefícios e custos, dada a própria heterogeneidade dos países membros. Houve, todavia, algum grau de especialização da produção, com a expansão do comércio, além de um maior aproveitamento da capacidade instalada. 
"Muitas são as explicações para o fracasso da ALALC, mas de uma maneira geral, o fracasso pode ser diagnosticado através do fato de que "Os problemas enfrentados pela ALALC não eram superficiais e ligavam-se às suas próprias raízes. $O$ programa proposto limitou-se, mesmo assim de modo extremamente tímido, aos processos de integração que representam o lado aparente e superficial deste fenômeno: as relações comerciais entre as partes que se integram" (Silva, 1990).

Mas, podemos elencar as razões que contribuíram para que a ALALC apresentasse resultados tímidos: (a) o abandono do "princípio de reciprocidade", pelo qual o país teria garantida uma elevação das exportações correspondente ao incremento das suas importações da região. 0 cumprimento do princípio de comércio equilibrado mostrou-se extremamente difícil; (b) o "plurilateralismo", isto é, a generalização compulsória das concessões revelou muito mais problemas que a concessão bilateral de reduções alfandegárias; (c) a inexistência de uma regulamentação sobre a implantação de novas indústrias, o que fez os países menores temerem a reprodução dentro da América Latina das disparidades entre a região e os países avançados centrais; (d) a ausência de harmonização das políticas macroeconômicas em geral, e das políticas comerciais em particular, foi certamente uma das razões do insucesso da ALALC; (e) a dificuldade de estimar os ganhos da integração dadas as distorções dos preços relativos devidas ao protecionismo. Foi comum associar os resultados da integração aos saldos das balanças comerciais; ( $f$ ) o principio de manutenção da "soberania nacional" que predispunha alguns governos desfavoravelmente à integração; (g) o crescimento das próprias desigualdades econômicas intrarregionais, por exemplo a nivel dos graus de desenvolvimento industrial; e, (h) um obstáculo grave que impediu o avanço da ALALC foi a oposição de setores e interesses internos a cada país, isto é, de produtores domésticos temerosos da concorrência que as importações dos países da região poderiam significar.

Paralelamente à ALALC, surgiram vários grupos sub-regionais que se uniram em entidades várias e adequaram às suas características nacionais projetos prioritários para constituição de áreas comuns de livre-comércio. Formado pelo Tratado de 
Manágua, em dezembro de 1960, o Mercado Comum Centro-Americano (MCCA), nasceu praticamente com o Tratado de Montevidéu (ALALC), reunindo a Guatemala, El Salvador, Honduras, Nicarágua e, em 1962, a Costa Rica. O documento constitutivo estatuiu e cumpriu, no prazo de cinco anos (1966), a meta de liberação tarifária de produtos do intercâmbio sub-regional para a constituição de união aduaneira com tarifa externa comum. Com sua sede na capital guatemalteca, o MCCA possui a sua própria nomenclatura aduaneira unificada.

No decorrer dos anos 70, a situação agravou-se na América Central com a eclosão de conflitos armados, que acirrariam posições radicais de grupos armados e guerras civis. A Comunidade Européia participou ativamente e com êxito na manutenção de ajuda econômica à América Central, reservando-Ihe (1985) cerca de $60 \%$ da assistência externa comunitária dada à América Latina, com prioridade para o desenvolvimento das estruturas rurais. Constituído pela Colômbia, México, Panamá e Venezuela, o Grupo Contadora recebeu apoio da CE na procura de solução pacífica para os conflitos (1984-1987). O Brasil uniu-se ao Grupo de Apoio a Contadora (1985) que, posteriormente, viria a constituir o Grupo do Rio (1988).

Os Acordos de Esquipulas (1986) reativaram as atividades do MCCA, dando início à série de reuniões presidenciais e redigindo Plano de Ação (1988) para expansão do movimento de integração, inclusive com substancial ajuda externa. Entendimentos com o México e a Venezuela levaram o acordo-macro para o estabelecimento de zona de livre comércio (1991) que foi considerado o primeiro passo para sua ampliação, com a participação do Grupo dos Três de dois países do Caribe. Mas assim como a primeira associação, "o descontentamento de alguns países com a marcha da integração e com vários aspectos institucionais e comerciais do programa vigente, advindos do conflito entre El Salvador e Honduras, agravaram mais esta situação de crise. Esta crise tem razões muito mais profundas ligadas à própria situação de dependência latino-americana" (Silva, 1990). 
Complementadas as atividades da ALALC, surgiram em 1963 e 1964 a Comissão Especial de Coordenação Latino-Americana (CECLA) e o Instituto para Integração da América Latina (INTAL). A CECLA, em 1970, tomou a iniciativa de estabelecer sistema permanente de cooperação com a Comunidade Européia, através do grupo de embaixadores latino-americanos em Bruxelas, o GRULA. O Sistema Econômico Latino-Americano (SELA) foi instituído em 1975, para promover a cooperação e integração regionais, bem como a coordenação dos países-membros da América Latina e do Caribe, no plano internacional.

Vários foram os movimentos para acelerar a "integração" durante os anos sessenta. A Caribbean Free Trade Association (CARIFTA) foi formada em abril de 1968, em Antígua, com a participação de quatro países (Barbados, Guiana, Jamaica e Trinidade-Tobago) e mais sete territórios (Antígua, Dominica, Granada, Montserrat, San Kitts-Nevis, Anguila, Santa Lúcia e São Vicente), aos quais Belisa aderiu em 1971. Os objetivos da associação eram a expansão, diversificação e eliminação de barreiras ao intercâmbio comercial, assegurando o crescimento econômico da região. Em 1973, os quatro países mencionados firmaram o tratado constitutivo do Mercado Comum do Caribe (CARICOM), ao qual aderiram, em 1974, os demais oito territórios integrantes da CARIFTA. Os gravames sobre importações procedentes da área foram reduzidos para $90 \%$, estabelecendo-se tarifa aduaneira e regras comuns de comércio extrazonal.

O CARICOM beneficiou-se, sobretudo, da Iniciativa do Caribe que the permite livre acesso, por duração indefinida, aos mercados dos Estados Unidos e do Canadá.

O Pacto Andino foi um dos exemplos mais representativos de um acordo subregional, proveniente da não concretização do mercado comum sob as perspectivas citadas anteriormente, mas que, por possuir muitos indícios de influências estrangeiras ligadas ao capital internacional, além do atraso de implantação dos programas, acabou por enfraquecer esta "nova" tentativa de integração entre alguns países latinoamericanos. Ainda, os países localizados no Cone Sul, por falta de efetividade dos outros programas, adotaram medidas que os aproximassem. 
agilizar o processo de liberalização do intercâmbio, intensificar a programação industrial, canalizar recursos públicos e investimentos estrangeiros para a área e harmonizar as políticas econômicas e sociais peculiares àquela sub-região. Nestes aspectos, o Grupo Andino evoluía de zona de livre comércio para a constituição de união aduaneira. Ou seja, a elaboração conjunta de esquema progressivo de liberação de impostos sobre comércio intrazonal, concomitantemente ao estabelecimento de tarifa externa comum.

O Acordo de Integração Andina registrou progressos sobre a ALALC pela criação de órgãos permanentes, bem como moeda escritural de caráter regional (peso andino), visivelmente inspirados nos mecanismos similares da Comunidade Européia. Dois membros, Equador e Bolívia, gozam de regimes especiais para Ihes favorecerem o crescimento econômico mais rápido. Por ocasião da assinatura do Acordo de Integração Sub-regional, a ALALC confirmou a compatibilidade do Grupo Andino com o I Tratado de Montevidéu, reconhecendo inclusive às nações de menor desenvolvimento relativo, ao aderirem ao Pacto Andino, tratamento similar ao concedido à Bolívia e ao Equador.

Constatados progressos iniciais, o novo esquema da costa do Pacifico passou a enfrentar crises institucionais. Em 1976, o Chile sob a ditadura Pinochet retirou-se do Grupo, alegando prejuízos decorrentes de normas concernentes aos investimentos estrangeiros e à tarifa externa comum. Neste último aspecto, alguns países relutaram em aceitar o regime tarifário e as limitações ao influxo de capitais estabelecidos para implementação do Programa Setorial de Desenvolvimento Industrial. Com a instalação do regime-forte Fujimori, no Peru, este país foi boicotado no Grupo Andino.

A partir da década de 70 , as relações comerciais entre Argentina, Brasil e Uruguai caracterizam-se pela utilização de vários convênios bilaterais de complementação econômica. 
A partir da década de 70 , as relações comerciais entre Argentina, Brasil e Uruguai caracterizam-se pela utilização de vários convênios bilaterais de complementação econômica.

Foi desta maneira que, em 1973, através da Ata das Cataratas, ocorreu a assinatura de um tratado entre o Brasil e o Paraguai, com vistas à construção da usina de Itaipu, em trecho contíguo a ambos países, no rio Paraguai.

A seguir surgiu o Acordo de Cooperação Econômica (CAUCE), em 1975, entre a Argentina e o Uruguai e o Protocolo de Expansão Comercial (PEC), em 1976, entre o Uruguai e o Brasil, medidas essas que foram fontes importantes para a dinamização do comércio exterior do Uruguai (Quijano, 1991).

Em 1979, através de um acordo tripartite - Brasil, Paraguai e Argentina - chegase a um denominador comum: a Argentina aceita o complexo de Itaipu como sendo uma obra irreversivel e o Brasil permite que Buenos Aires e Assunção construam, conjuntamente, a usina de Corpus.

Em 1980, reconhecendo o fracasso da ALALC, surge em seu lugar, através da assinatura do Tratado de Montevidéu, a ALADI (Associação Latino-Americana de Integração), impulsionada pelo aumento da retórica integracionista em face da crise do petróleo dos anos 70 , o que estimulou a princípio o comércio intra-regional, mas que, devido ao contexto recessivo internacional, foi bastante limitado.

A ALADI previa novos mecanismos, com objetivos mais limitados e caracterizados por maiores realismo e flexibilidade. Buscava-se compatibilizar acordos bilaterais ou sub-regionais ao aparelho institucional pré-existente, visando agora à integração econômica por convergência, a partir de acordos mais limitados do ponto de vista setorial ou geográfico.

Entre os instrumentos multilaterais, a Preferência Alfandegária Regional (PAR) tem especial importância como antecedente do MERCOSUL. Ela entrou em vigor em 
1984 e determinou a redução percentual das tarifas alfandegárias para importação de produtos regionais entre os países membros da ALADI.

As preferências negociadas foram estabelecidas segundo três tipos de países: (a) os de menor desenvolvimento relativo (Equador, Bolívia e Paraguai); (b) os países de desenvolvimento intermediário (Chile, Colômbia, Peru, Uruguai e Venezuela); (c) os demais países definidos como os de maior desenvolvimento relativo (Argentina, Brasil e México).

A PAR aplica-se a todo o universo alfandegário, exceto por uma lista de produtos que cada país considera "sensíveis", porém dentro de uma quantidade limitada de acordo com os diferentes tipos de países: quanto menor é o grau de desenvolvimento do país, maior a lista de produtos "sensíveis". Cabe destacar que a extensão dessas listas de exceções tem limitado seriamente o êxito do mecanismo, a ponto de somente canalizar $20 \%$ do comércio regional. Em paralelo à PAR negociaram-se nada menos que 130 acordos de alcance parcial. Os convênios bilaterais que triangularizam as relações comerciais entre Argentina, Brasil e Uruguai denominam-se Acordos de Complementação Econômica (ACE), mas sua utilização não têm se estendido além dos países do Cone Sul.

As perspectivas da ALADI são ainda, porém, tímidas, em função da limitação das margens de preferência face à ampla heterogeneidade dos patamares de tarifação nos países da área.

Segundo Teixeira (1991) a ALADI abriu caminho para a criação do MERCOSUL, pois propunha inicialmente uma zona de preferências comerciais a ser formàda mediante a celebração de Acordos de Alcance Parcial entre dois ou mais países. Neste estágio de integração tem-se tarifas preferenciais entre os países.

Sintetizando, a experiência ALALCIALADI foi relativamente modesta, porém válida. O enfraquecimento ocorreu, porque seus membros preferiram manter 0 intercâmbio comercial, principalmente com os EUA e a Europa, em vez de elevar o 
comércio intra-regional. A viabilidade do sistema foi reduzida, devido à heterogeneidade de desenvolvimento industrial e econômico, a dificuldades de transporte e de comunicação entre o sul e o norte da América Latina e à contrastante superioridade tecnológica ou financeira de alguns paises em relação a outros. 0 México entrou na órbita de influência econômica dos EUA com adesão ao Acordo de Livre Comércio da América do Norte (NAFTA) e houve a formação de um subsistema denominado Pacto Andino. Enquanto a ALALC atuava em base de negociações multilaterais, a ALADI passou a incorporar entendimentos bilaterais, reconhecendo, como a Comunidade Européia, interesses nacionais, concedendo tratamentos especiais a países menos desenvolvidos.

\subsection{A Integração econômica nos anos oitenta e noventa}

Embora a idéia da integração econômica tenha começado a ter vigência na América Latina em inícios da década de 50, sob o impulso da CEPAL, só modernamente é que a região pode dar significativos passos em direção à uma integração mais efetiva.

Frustados frente à impossibilidade de atingir ou reformular os objetivos propostos nos modelos tradicionais de integração econômica, alguns países da América Latina procuraram novos modelos, para enfrentar os desafios da economia competitiva globalizada deste final de milênio. Enfrentaram, também, a consolidação de poderosos blocos regionais e o acirramento da concorrência internacional.

Os projetos de integração, em andamento, passaram por uma profunda reformulação, principalmente os da Comunidade do Caribe, do Mercado Comum Centro Americano e do Pacto Andino. O fortalecimento das relações bilaterais, por meio de novos acordos de complementação econômica e de livre comércio, foi a saída encontrada por diversos países. 
Os acordos entre Brasil e Argentina, incorporando lições do passado, propõem um processo mais gradual, progressivo e realista que as tentativas anteriores. Em novembro de 1985, em Foz do Iguaçu, o encontro entre os presidentes Raúl Alfonsin e José Sarney produz a Declaração de Iguaçu, em que se afirma a necessidade da união de esforços para a defesa conjunta dos interesses argentino-brasileiros no plano internacional.

Em junho de 1986, em Buenos Aires, os presidentes da Argentina e do Brasil assinam a Ata para a integração Brasileiro-Argentina e mais doze protocolos, iniciando o Programa de Integração e Cooperação Econômica entre os dois países.

Ainda, em dezembro de 1986, em Brasília, é assinada a Ata de Amizade Brasileiro-Argentina, que eleva para dezessete o número de protocolos do Programa. Em função de negociações posteriores, o Programa é ampliado, passando a abranger vinte e quatro protocolos que contemplam os mais diversos temas, com prioridade para a expansão comercial e a troca de conhecimentos técnico-científicos em áreas como energia nuclear e biotecnologia, mas incluindo também a cooperação cultural para o treinamento de recursos humanos em vários campos de atividade.

A própria Constituição da República Federativa do Brasil, promulgada em 5 de outubro de 1988, manifesta explicitamente a intenção integracionista em seu título I (dos princípios fundamentais), artigo $4^{\circ}$ (dos princípios nas relações internacionais), parágrafo único: "A República Federativa do Brasil buscará a integração econômica, política, social e cultural dos povos da América Latina, visando à formação de uma comunidade latino-americana de nações".

Em novembro de 1988, em Buenos Aires, assina-se o Tratado de Integração e Cooperação Econômica entre o Governo da República Federativa do Brasil e o Governo da República Argentina, depois aprovado pelos dois congressos nacionais em agosto de 1989, visando à formação de um Mercado Comum entre os dois países no prazo de dez anos. Ainda, em 1988, foram assinados 11 protocolos visando um maior intercâmbio comercial, criação de empresas binacionais, etc. (Catania, 1990). 
Marques (1991) cita várias tentativas de integração econômica através de relações bilaterais que contribuiram para o surgimento do MERCOSUL, ou seja, a celebração do Acordo Tripartite já mencionado neste trabalho, sobre o aproveitamento dos recursos hídricos do rio Paraná; o Convênio de Cooperação Nuclear de 1980; a Ata de Iguaçu em 1985 e o Tratado de Integração, Cooperação e Desenvolvimento de 1988.

Em virtude das necessidades do próprio processo de desenvolvimento mundial, ou seja, da formação de blocos, em julho de 1986 foi assinada a Ata para a Integração Brasileiro-Argentina, onde ficou decidido "estabelecer o Programa de Integração e Cooperação Econômica entre a República Federativa do Brasil e a República Argentina (...)" (Macadar e Bello, 1990).

Iniciou-se, já com os primeiros protocolos de integração e cooperação assinados, um processo de discussões no sentido de se efetivarem medidas para a retomada do crescimento, onde a recuperação dos investimentos e a difusão de inovações tecnológicas estivessem relacionadas com o processo de integração, proporcionando a recuperação crescente das economias destes países. Neste período, o Uruguai inseriu-se no movimento dos países vizinhos.

$\mathrm{Na}$ década de 90 inicia-se uma tendência para a segmentação da economia mundial em blocos regionais que se caracterizam por agrupamento de países menos industrializados, em torno de um ou mais países centrais, com o objetivo principal de substituir a concorrência entre nações pela concorrência entre regiões. Os processos de integração estão se efetivando como estratégia de defesa à formação de outros blocos como tentativa de aumentar o nivel de competitividade de modo a garantir sua sobrevivência e inserção no cenário internacional.

Em 1991, em documento divulgado pela CEPAL já se mencionava a aproximação entre o Brasil e a Argentina, indicando uma nova fase na integração latino-americana, dando ênfase na abertura simultânea do comércio regional e internacional, através da eliminação de todo tipo de barreiras ao intercâmbio, e da 
efetiva integração entre as economias a partir da complementação e a criação do comércio.

Em 1991, já com a inserção do Paraguai, concretizou-se o Tratado de Assunção, que colocou efetivamente em andamento o projeto de integração, através da criação do Mercado Comum do Sul - MERCOSUL.

\subsection{MERCOSUL - Mercado Comum do Sul}

Quatro países escolhem uma forma de assumir suas inter-relações, bem como de conviver com a comunidade econômica mundial.

Em meados de 1990, os presidentes do Brasil e da Argentina, Fernando Collor de Mello e Carlos Meném, respectivamente, firmaram a Ata de Buenos Aires, fixando o prazo de 31 de dezembro de 1994 para a consolidação efetiva do Mercado Comum entre o Brasil e a Argentina, estabelecendo como principal objetivo do processo de integração as reduções tarifárias lineares, generalizadas e automáticas, até atingir tarifa zero. Atribuíram, ainda, ao mercado o papel do mecanismo principal de alocação de recursos e cerceia-se a capacidade governamental de alocar diretamente recursos produtivos e localizações (CEPAL, 1992). No mesmo ano, ainda, tanto o Paraguai como o Uruguai foram convidados para fazerem parte desse processo em andamento.

O Mercado Comum do Sul (MERCOSUL) entre a Argentina, Brasil, Paraguai e Uruguai entrou em vigor em 26 de março de 1991 com a assinatura do Tratado de Assunção pelos governos destes respectivos países, baseando-se em fatos históricos de cooperação e na convergência das políticas macroeconômicas. Os presidentes ponderaram que a unificação dos mercados era requisito essencial para o desenvolvimento econômico e a melhor opção para inserir, de maneira conveniente, os países-membros no âmbito internacional. $O$ Tratado consta de seis capítulos, vinte e 
quatro artigos e cinco anexos e logo no seu preâmbulo pode-se confirmar a intenção dos Estados-Partes com relação ao processo de integração onde "a ampliação das atuais dimensões de seus mercados nacionais, através da integração, constitui condição fundamental para acelerar seus processos de desenvolvimento econômico com justiça social" (Brasil, 1991, p. 37).

Os pontos mais importantes do MERCOSUL são: a abertura comercial e integração econômica dos quatro países até dezembro de 1994; maior competitividade no comércio internacional, decorrente da complementarização das economias dos quatro países; a promoção de um meio ambiente melhor para investimentos na região e o fortalecimento de economias de escala.

Já no primeiro artigo, é estabelecido como objetivo constituir um Mercado Comum que deverá estar consolidado a 31 de dezembro de 1994 ou seja, no curto espaço de quatro anos, e que esse mercado comum implicará:

"A livre circulação de bens, serviços e fatores produtivos entre os países, através, entre outros, da eliminação dos direitos alfandegários e restrições nãotarifárias à circulação de mercadorias e de qualquer outra medida de efeito equivalente;

O estabelecimento de uma tarifa externa comum e a adoção de uma política comercial comum em relação a terceiros Estados ou agrupamentos de Estados e a coordenação de posições em foros econômico-regionais e internacionais;

A coordenação de políticas macroeconômicas e setoriais entre os Estados Partes - de comércio exterior, agrícola, industrial, fiscal, monetária, cambial e de capitais, de serviços, alfandegária, de transportes e comunicações e outras que se acordem -, a fim de assegurar condições adequadas de concorrência entre os Estados Partes, e o compromisso dos Estados Partes de harmonizar suas legislações, nas áreas pertinentes, para lograr o fortalecimento do processo de integração" (Brasil, 1991, p. 37). 
Hirst (1992), sintetiza o artigo primeiro do Tratado de Assunção reforçando que um Mercado Comum requer: a livre circulação de bens, serviços e fatores de produção entre os quatro países membros; o estabelecimento de uma tarifa externa comum e a adoção de uma política comercial comum em relação a terceiros Estados; a coordenação de políticas macroeconômicas e setoriais entre os Estados membros; e o compromisso destes Estados de harmonizarem suas legislações nas áreas correspondentes.

No Tratado, os governantes assumiram, também, o compromisso de respeitar os acordos anteriores, firmado pelas quatro nações, principalmente no âmbito da ALADI.

Entre setembro e outubro de 1991, os congressos nacionais dos países membros ratificaram os termos do Tratado de Assunção.

A semelhança das estratégias econômicas nacionais e a eficaz coordenação das políticas macroeconômicas dos quatro países, foram os requisitos fundamentais para o sucesso dessa fase de integração. Portanto, os primeiros resultados positivos dos programas de ajuste econômico demonstraram que os instrumentos utilizados foram corretos e que os objetivos do Tratado de Assunção poderão ser alcançados.

$\mathrm{Na}$ verdade, os acordos entre Brasil-Argentina, assinados em 1985 pelos presidentes dos dois paises, e, as negociações iniciadas em setembro de 1990 para a formação de um "Mercado Comum do Sul", para englobar também o Paraguai e o Uruguai, contribuíram para o surgimento do MERCOSUL.

O Tratado de Integração Brasil-Argentina norteou os termos e parâmetros do Tratado de Assunção e estabeleceu a intenção de se constituir, até dezembro de 1994, um mercado comum.

O Tratado de Assunção busca à criação de um "mercado comum" que como forma de integração prevê a livre circulação de bens, serviços e fatores de produção entre os quatro países através da eliminação dos direitos alfandegários e das 
restrições não tarifárias à circulação de mercadorias ou qualquer outra medida de efeito equivalente.

O Tratado prevê, ainda, a redução a zero das tarifas alfandegárias entre os países membros e tarifas iguais para o resto do mundo e a articulação das políticas macroeconômicas e setoriais entre os quatro países - políticas fiscal, monetária, agrícola, cambial, industrial, de transporte, entre outras que se fizerem necessários.

Segundo Branco (1991), dos pontos elencados no Tratado de Assunção, os Estados membros procuraram o desenvolvimento econômico e social como o principal objetivo deste mercado comum.

O artigo do DIEESE (1992) coloca que a idéia do MERCOSUL está vinculada à pregação de abertura dos mercados, da "modernidade", e da livre circulação de mercadorias e mão-de-obra. Como surge com a onda neoliberal que invade a América Latina, toda a ênfase é posta na questão dos ganhos de escala e no aumento de produtividade, enquanto que a questão social é ignorada.

Em seu trabalho, Hirst (1992) aponta como principal objetivo da integração entre Argentina, Brasil, Paraguai e Uruguai, a criação de um espaço econômico integrado entre o Brasil e os países do Cone Sul. Ainda segundo a autora, os principais desafios do MERCOSUL, serão o estabelecimento de uma tarifa externa comum e a harmonização das políticas macroeconômicas.

Além dos objetivos apontados anteriormente, o MERCOSUL enquanto integração regional visa ampliar o potencial produtor-consumidor de uma região ao gerar economias de escala, beneficiando tanto a produção como o consumo regional. Ainda, pode possibilitar o fortalecimento das economias através da inserção competitiva no mercado mundial, tornando os investimentos mais atrativos nas regiões participantes deste processo.

O MERCOSUL é sem dúvida uma tentativa ambiciosa de se formar uma área de mercado comum pois, segundo os países que assinaram o Tratado de Assunção, a 
integração levaria a uma ampliação dos mercados de tal sorte que todos seriam beneficiados: os consumidores teriam uma maior quantidade de bens à sua disposição a preços reduzidos e os produtores que sobrevivessem à competição teriam um mercado muito maior para os seus produtos.

\subsubsection{O periodo de transição}

No período compreendido entre a assinatura do Tratado de Assunção e a instauração do Mercado Comum, foram negociados alguns instrumentos para facilitar a constituição do Mercado Comum, entre eles:

a) um programa de liberalização gradual do comércio, que consistiu em reduções tarifárias progressivas e lineares, além do compromisso da eliminação das restrições não tarifárias de qualquer natureza;

b) a coordenação das políticas macroeconômicas, que se realizou com a desgravação tarifária e com a eliminação das restrições não tarifárias;

c) uma tarifa externa comum;

d) a adoção de acordos setoriais.

\subsubsection{A estrutura do MERCOSUL}

A execução do Tratado de Assunção está a cargo de dois órgãos distintos, sendo: 
a) Conselho do Mercado Comum - é o órgão superior que cuida da condução da política do processo de integração e da tomada de decisão para o cumprimento dos objetivos do Tratado de Assunção. É composto pelos Ministros das Relações Exteriores e da Economia dos Estados-Membros; e

b) Grupo Mercado Comum - é o órgão executivo do MERCOSUL e tem a função de coordenar os subgrupos de trabalhos técnicos, formular sugestões e propor medidas concretas para cumprimento das obrigações assumidas pelos países. 0 Grupo é integrado apenas pelos Ministros de Relações Exteriores dos Estados-Partes.

Com o objetivo de facilitar o avanço até a conformação do Mercado Comum, estabeleceu-se uma Comissão Parlamentar Conjunta como canal de representação dos parlamentos dos quatro países, de caráter consultivo e deliberativo, com suas atribuições específicas.

O artigo 18 indica que "antes do estabelecimento do Mercado Comum, a 31 de dezembro de 1994, os Estados-Partes convocarão uma reunião extraordinária com o objetivo de determinar a estrutura institucional definitiva dos órgãos de administração do Mercado Comum, assim como as atribuições específicas de cada um deles e seu sistema de tomada de decisões" (Brasil, 1991, p. 39).

Agregaram-se a essa estrutura conforme podemos ver no figura 2.1 a seguir:

a) a Comissão de Comércio do MERCOSUL que assiste o Grupo Mercado Comum, zelando pela aplicação dos principais instrumentos de política comercial comum pelos Estados-Partes para funcionamento da união aduaneira e acompanha o desenvolvimento dos temas e matérias relacionadas às políticas comerciais comuns ao comércio intra-MERCOSUL e a terceiros países;

b) A Secretaria Administrativa do MERCOSUL que presta apoio operacional e serviços aos órgãos do MERCOSUL; a sede permanente é em Montevidéu, no Uruguai, conforme decisão da reunião de presidentes, em Fortaleza, com funções e atribuições especificas; e 
c) O Foro Consultivo Econômico-Social de caráter consultivo privado, que permite aos diferentes setores da sociedade (sindicatos, consumidores, sociedade civil em geral) encaminhar seus pleitos e proposições aos órgãos de decisão.

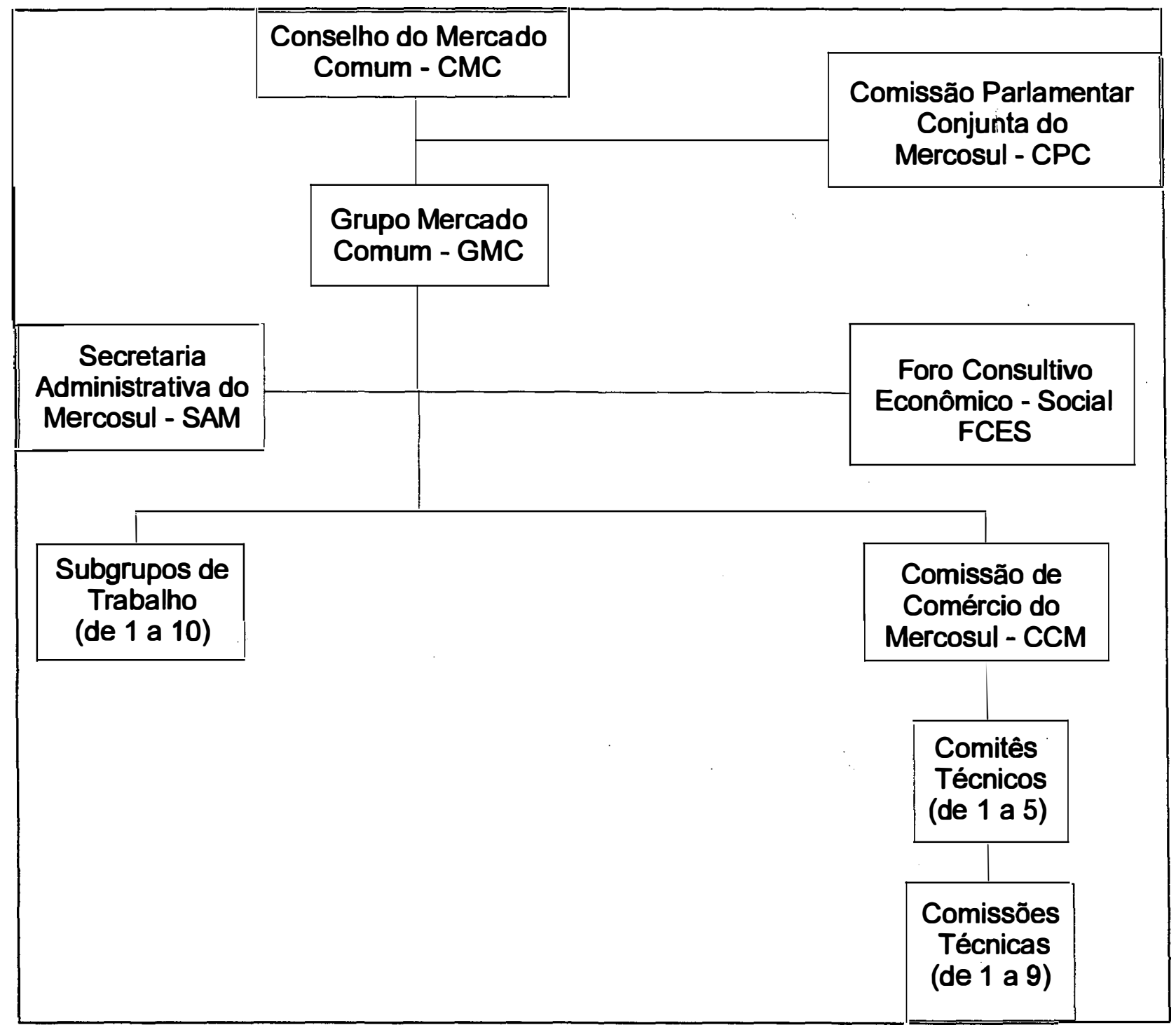

Figura 2.1 - A estrutura do MERCOSUL

O Tratado está aberto à adesão dos demais países-membros da ALADI, mas as solicitaçồes somente poderão ser encaminhadas depois de cinco anos de vigência do 
Tratado. A única exceção é para os países-membros da ALADI que não fazem parte de outros esquemas de integração sub-regional ou de associação extra-regional.

Em novembro de 1991 foi registrado na ALADI o Acordo de Complementação Econômica número 18 (ACE-18), inscrevendo o Tratado de Assunção como um Acordo de Alcance Parcial entre quatro membros dessa Associação.

O Tratado de Assunção apresenta, ainda, cinco anexos, cuja constituição segue aqui:

a) Anexo I - estabelece o sistema progressivo de redução das tarifas alfandegárias e das listas de exceções contempladas no comércio entre os quatro países:

b) Anexo II - institui o regime de qualificação de origem, isto é, são estabelecidos graus mínimos de nacionalização dos produtos para que esses bens recebam o tratamento de nacionais e se beneficiem do programa de desgravação;

c) Anexo III - trata da sistemática que será utilizada para a solução de controvérsias;

d) Anexo IV - regula a aplicabilidade de cláusulas de salvaguarda à importação;

e) Anexo V - fixa um prazo de trinta dias após a entrada em vigor do Tratado para a criação de subgrupos de trabalho necessários à coordenação das políticas macroeconômicas e setoriais. Foram previstos dez subgrupos com a finalidade de tratar assuntos específicos para a concretizacão do Mercado Comum. 


\subsubsection{Regime geral de origem}

As regras de origem são estabelecidas por um grupo de países que fazem parte de um esquema preferencial, pelas seguintes razões:

a) evitar distorções no comércio quando os países membros mantêm tarifas de importação diferenciadas em relação a terceiros países;

b) obtenção de vantagens proporcionadas pelo esquema preferencial, ao comprovar que mercadorias importadas de países membros sejam efetivamente produzidas neles ou tenham sofrido uma transformação substancial;

c) comodidade no intercâmbio de mercadorias quando estas cumprem os requisitos para seu ingresso em qualquer um dos países membros.

\subsubsection{Solução de controvérsias}

Na primeira reunião de cúpula, em 1991, denominada Protocolo de Brasília, foi estabelecido um inédito sistema de solução de controvérsias sobre a interpretação, aplicação ou descumprimento dos acordos celebrados no âmbito do MERCOSUL. $O$ sistema baseia-se em instrumento de caráter jurídico, portanto, obrigatório.

A agilidade na criação de um sistema viável para solucionar controvérsias preenche a necessidade básica de dotar o MERCOSUL de um mecanismo jurídico prático e eficaz. 


\subsubsection{Cláusula de salvaguarda}

A cláusula de Salvaguarda prevista no Tratado de Assunção foi utilizada exclusivamente no comércio entre os países do MERCOSUL, não afetando o comércio com terceiros. A medida destinava-se a corrigir eventuais distorções que o processo de desgravação pudesse provocar durante a fase de transição.

A resolução 6/93 do Grupo Mercado Comum estabelecia os procedimentos para aplicar a cláusula de salvaguarda no MERCOSUL como um recurso aplicável "às importações de determinado produto, originário ou proveniente dos países do MERCOSUL quando o sensivel aumento das mesmas produzidas por um curto período provoque ou ameace provocar dano grave a seu mercado nacional".

\subsubsection{A Tarifa externa comum - TEC}

O artigo 5 do Tratado de Assunção prevê o estabelecimento de uma Tarifa Externa Comum (TEC) e a coloca como um instrumento de incentivo à "competitividade externa dos Estados-Parte" durante o período de transição. A TEC é importante para garantir o futuro da integração. Para o Brasil, ela se torna importante, uma vez que o crescimento do comércio regional com taxas mais baixas nos demais Estados-Parte pode afetar o parque industrial brasileiro, via desvio de comércio.

Como previsto pelo Tratado de Assunção, no dia $1^{\circ}$ de janeiro de 1995 o MERCOSUL avançou para uma área de livre comércio, embora apresentando uma lista de produtos em regime de adequação, e para uma união aduaneira imperfeita, com uma Tarifa Externa Comum (TEC) entre 0 e $20 \%$ para aproximadamente $90 \%$ do universo alfandegário (Rego, 1995). 


\subsection{O MERCOSUL e as novas parcerias}

A primeira metade dos anos 90 foi marcada pelo pacto comercial celebrado entre Argentina, Brasil, Paraguai e Uruguai. Já a segunda metade tem seu início caracterizado pelas iniciativas de articulação com outros países ou grupos de países.

Os países que constituem o MERCOSUL encaram sua associação como um meio de aproximar a região dos objetivos definidos pela Associação Latino-Americana de Integração (ALADI). O Tratado de Assunção declara que o bloco deve ser considerado como uma etapa do processo de integração da América Latina. $O$ MERCOSUL é uma plataforma para a inserção dos países membros na economia internacional.

O caráter aberto do bloco evidencia-se de duas formas: por um lado, existe a possibilidade de adesão de novos membros, prevista no artigo 20 do Tratado; por outro, ocorrem as negociações com países ou esquemas regionais.

Nos últimos tempos, a agenda externa vem ampliando-se consideravelmente, tendo se revelado geograficamente diversificada, envolvendo iniciativas nos planos regional, hemisférico e extra-hemisférico. Três temas constituem os pontos principais dessa articulação:

a) a renegociação, no formato $4+1$, dos acordos firmados bilateralmente pelos parceiros do MERCOSUL com os demais países da ALADI, especificamente, Chile, Bolívia, México e o restante do Pacto Andino - Peru, Venezuela, Equador e Colômbia. É uma primeira etapa para a celebração de acordos de livre comércio, que, por sua vez, abrirá caminho para a formação da Área de Livre Comércio Americana (ALCA). Além disso, esse tipo de negociação procura evitar perfurações à Tarifa Externa Comum (TEC); 
b) as negociações relacionadas com a constituição de uma Área de Livre Comércio Americana (ALCA), previstas para se encerrarem até o ano de 2005; e

c) as negociações envolvendo o acordo UE-MERCOSUL.

\subsubsection{Chile}

O Acordo de Complementação Econômica (ACE) entre os países do MERCOSUL e o Chile foi assinado em junho de 1996, passando a vigorar em primeiro de outubro do mesmo ano. $O$ acordo permite integrar o Chile, de forma parcial, através de uma zona de livre comércio, abrangendo unicamente a eliminação das barreiras tarifárias e não-tarifárias ao comércio, num período médio de dez anos, sem que o mesmo seja obrigado a adotar as alíquotas de importação da TEC. O objetivo original chileno incluía, ainda, a liberalização nas áreas de serviços e investimentos, regras de solução de controvérsias e garantia de acesso bilateral aos mercados de bens e serviços.

Já em meados da década de 70 , o Chile iniciou um processo de liberalização comercial, com ênfase na unilateralidade e caracterizado pela existência de tarifas baixas . Enquanto a alíquota média de importação do bloco MERCOSUL, adotada a partir de primeiro de janeiro de 1995 , ainda está na faixa dos $20 \%$, o Chile, opera com tarifas médias de importação de $11 \%$.

Desde 1991, o país orienta a sua estratégia de comércio exterior para acordos bilaterais ou regionais, entre os quais se destaca a negociação com o MERCOSUL. Somente no início de julho de 1994 é que o Chile manifestou oficialmente a intenção de associar-se ao MERCOSUL, em regime de área de livre comércio. 


\subsubsection{Bolívia}

Com a finalidade de formar uma zona de livre comércio reduzindo as tarifas no prazo de dez anos, o MERCOSUL e a Bolívia definiram as bases para a entrada em vigor, a partir de 01/01/97, de um novo Acordo de Complementação Econômica.

A Bolívia não poderia ingressar como membro pleno no MERCOSUL, uma vez que, no Tratado de Assunção, há uma cláusula assinalando que, em um prazo de cinco anos de sua vigência, não poderão fazer parte do bloco os países que pertencem a outros acordos regionais. A saída então foi a negociação de um acordo de livre comércio.

Em 1994, a Bolívia começou a participar como observadora das reuniões semestrais do Conselho do Mercado Comum. Na cúpula presidencial de Fortaleza, celebrada em dezembro de 1996, o MERCOSUL e a Bolívia assinaram o ACE, do qual consta o Programa de Liberalização Comercial que, de forma paulatina e automática, liberalizará o comércio recíproco. No comunicado final, foi anunciado o desejo de concluir as negociações ainda em 1997. O Acordo teve a sua implementação adiada por quatro meses, de primeiro de janeiro (a data preliminarmente fixada pelos negociadores) para 30 de abril de 1997.

O novo Acordo substitui o ACE 34, acertado em dezembro de 1995, por intermédio do qual foram unificadas as concessões oferecidas pelos membros do MERCOSUL e pela Bolívia, um a um.

O Acordo com a Bolívia inclui aspectos normativos vinculados às restrições não tarifárias, regime geral de origem, medidas de salvaguarda e mecanismos de solução de controvérsias. O Acordo será benéfico se criar condições para melhorar a posição dos exportadores no MERCOSUL e contribuir para a atração de investimentos destinados a melhorar a limitada oferta exportável atual. 


\subsubsection{Reflexos da entrada do Chile e Bolívia no MERCOSUL}

As associações do Chile e da Bolivia ao MERCOSUL foram por razões diferentes. O Chile traz para o MERCOSUL sua reconhecida eficiência exportadora. Reconhece com sua associação à primeira etapa do MERCOSUL, isto é, na Zona de Livre Comércio, que seria imprudência ignorar o bloco regional de seus vizinhos e, especialmente para o Brasil, viabiliza o Pacífico. A associação da Bolívia, um dos componentes do Pacto Andino, tem a importância estratégica da abertura para negociações com o Bloco Andino, caminhando em direção à formação da Área de Livre Comércio Sul-Americana (ALCSA). Ela beneficia especialmente o Brasil e passa pelo imenso gasoduto que vai proporcionar uma significativa redução de custos e alavancar o desenvolvimento de regiões com deficiência de suprimento energético.

A Bolívia ganha com o MERCOSUL o acesso ao mar, em direção ao Pacífico, pelo Chile, e ao Atlântico, pelo Brasil. Para o MERCOSUL, a Bolívia não tem a mesma expressão que o Chile, comercialmente. Mas, o Acordo representa um passo importante, no sentido de constituir uma rede de acordos de livre comércio sulamericanos, vinculados à união aduaneira.

\subsection{4 Área de Livre Comércio das Américas - ALCA}

A proposta de criação da Área de Livre Comércio das Américas (ALCA), prevista para março de 1998, abrange todo o continente americano, do Alasca à Terra do Fogo, e acompanha a tendência de liberalização comercial em todo mundo. Tem como um dos objetivos eliminar as barreiras comerciais existentes entre os paises da região, para criar um mercado comum, mediante a suspensão da cobrança de tarifas aduaneiras. Envolve uma população de 800 milhões de pessoas, aproximadamente, e 
um PIB estimado em US $\$ 8,8$ trilhões. No continente existe cinco blocos econômicos, a saber: NAFTA, MERCOSUL, Pacto Andino, CARICOM e Mercado Comum CentroAmericano.

Os princípios adotados para a criação da ALCA incluem: a maximização da abertura dos mercados com base nos acordos existentes no hemisfério; a plena convergência dos dispositivos da Organização Mundial do Comércio - OMC; a abrangência de todas as áreas contempladas no Plano de Ação, o que demonstra a intenção de ampliar as áreas de que tratam os acordos negociados pelo GATT, na Rodada Uruguai. Todas as siglas utilizadas neste capítulo se encontram no Apêndice A. 


\section{CARACTERÍSTICAS DOS PAÍSES DO MERCOSUL}

\subsection{Perfil dos paises do MERCOSUL}

O programa do MERCOSUL, estabelecido pelo Tratado de Assunção, abrange uma área de 11,9 milhões de quilômetros quadrados, equivalendo aproximadamente a $9 \%$ da superfície ocupada por todos os países do mundo, onde estão cerca de 200,9 milhões de habitantes que, em 1994, correspondiam a $43 \%$ da população da América Latina e a 73\% da população dos Estados Unidos e um PIB da ordem de US\$1.011,1 bilhões (ver Tabela 3.1).

Tabela 3.1 - MERCOSUL - Dados Gerais - 1995

\begin{tabular}{lccccc}
\hline \multicolumn{1}{c}{ Indicadores } & BRASIL & ARGENTINA & PARAGUAl & URUGUAl & MERCOSUL \\
\hline & & & & & \\
População (milhões) & 159 & 33,9 & 4,8 & 3,2 & 200,9 \\
Área (milhões Km2) & 8,5 & 2,8 & 0,4 & 0,2 & 11,9 \\
Densidade Demográfica (hab/Km2) & 18,3 & 12,2 & 11,4 & 17,6 & 17 \\
Taxa de Natalidade (nasc/1000hab) & 23,3 & 20,3 & 33,1 & 17,1 & 23,4 \\
PIB (bilhões US\$) & 701,5 & 282,8 & 9 & 17,8 & 1011,1 \\
PIB per capita (US $\$$ ) & 4.411 & 8.342 & 1.875 & 5.562 & 5.033 \\
Crescimento do PIB (\%) & 4,2 & $-4,4$ & 4,7 & -2 & 1,5 \\
Exportaçöes (US $\$$ bilhões) - FOB & 46,5 & 20,9 & 1,9 & 2,1 & 71,4 \\
Importações (US $\$$ bilhöes) - FOB & 49,7 & 18,7 & 3 & 2,6 & 74,3 \\
Saldo Balança (US $\$$ milhões) & $-3,2$ & 2,2 & $-1,4$ & $-0,5$ & $-2,9$ \\
Reservas (US $\$$ bilhöes) & 49,7 & 14,3 & 1 & 1,1 & 66,1 \\
\hline
\end{tabular}

Fonte: The Economist Intelligence Unit (EUI). Londres, 1996. 


\subsection{Desempenho do Brasil no comércio internacional}

O Brasil, a partir de 1980, vinha apresentando saldos comerciais significativos, dentro de uma política de comércio exterior que incentivava as exportações e continha as importações, seguindo os imperativos das negociações da dívida externa brasileira. Assim, por 15 anos, aproximadamente, o país apresentou saldos positivos na sua balança comercial.

As exportações brasileiras evoluíram de US $\$ 20,1$ bilhões em 1980, para US $\$$ 47,7 bilhões em 1996. O crescimento global desses dezesseis anos foi de $137 \%$. Cabe ressaltar que de 1991 para 1992 o crescimento foi de 13\%, e de 1992 para 1993, de $8 \%$, contrastando com o crescimento mundial de apenas 4\%. (ver Tabela 3.2 e Gráfico $3.1)$.

O desempenho do Brasil em 1992 e 1993 reverteu um quadro de estagnação de 1990 e 1991, quando as exportações cairam de US $\$ 34,4$ bilhões em 1989 para US\$ 31,4 bilhões em 1990 e US $\$ 31,6$ bilhões em 1991, aproximadamente, voltando a evoluir a partir de 1992. (Ver Tabela 3.2). 
Tabela 3.2 - Brasil: intercâmbio comercial Totais Gerais (US\$ Milhões) FOB

\begin{tabular}{cccc}
\hline Ano & Exportações & Importações & Saldo \\
\hline 1980 & 20.132 & 22.955 & -2.804 \\
1981 & 23.293 & 22.091 & 1.202 \\
1982 & 20.175 & 19.395 & 779 \\
1983 & 21.899 & 15.429 & 6.470 \\
1984 & 27.005 & 13.916 & 13.098 \\
1985 & 25.639 & 13.153 & 12.471 \\
1986 & 22.349 & 14.044 & 6.294 \\
1987 & 26.224 & 15.051 & 11.174 \\
1988 & 33.789 & 14.605 & 19.186 \\
1989 & 34.383 & 18.263 & 16.125 \\
1990 & 31.414 & 20.661 & 10.752 \\
1991 & 31.620 & 21.041 & 10.579 \\
1992 & 35.793 & 20.554 & 15.308 \\
1993 & 38.555 & 25.256 & 13.009 \\
1994 & 43.545 & 33.079 & 10.583 \\
1995 & 46.506 & 49.858 & -3.352 \\
1996 & 47.747 & 53.286 & -5.539 \\
\hline
\end{tabular}

Fonte: Secretaria do Comércio Exterior - SECEX 


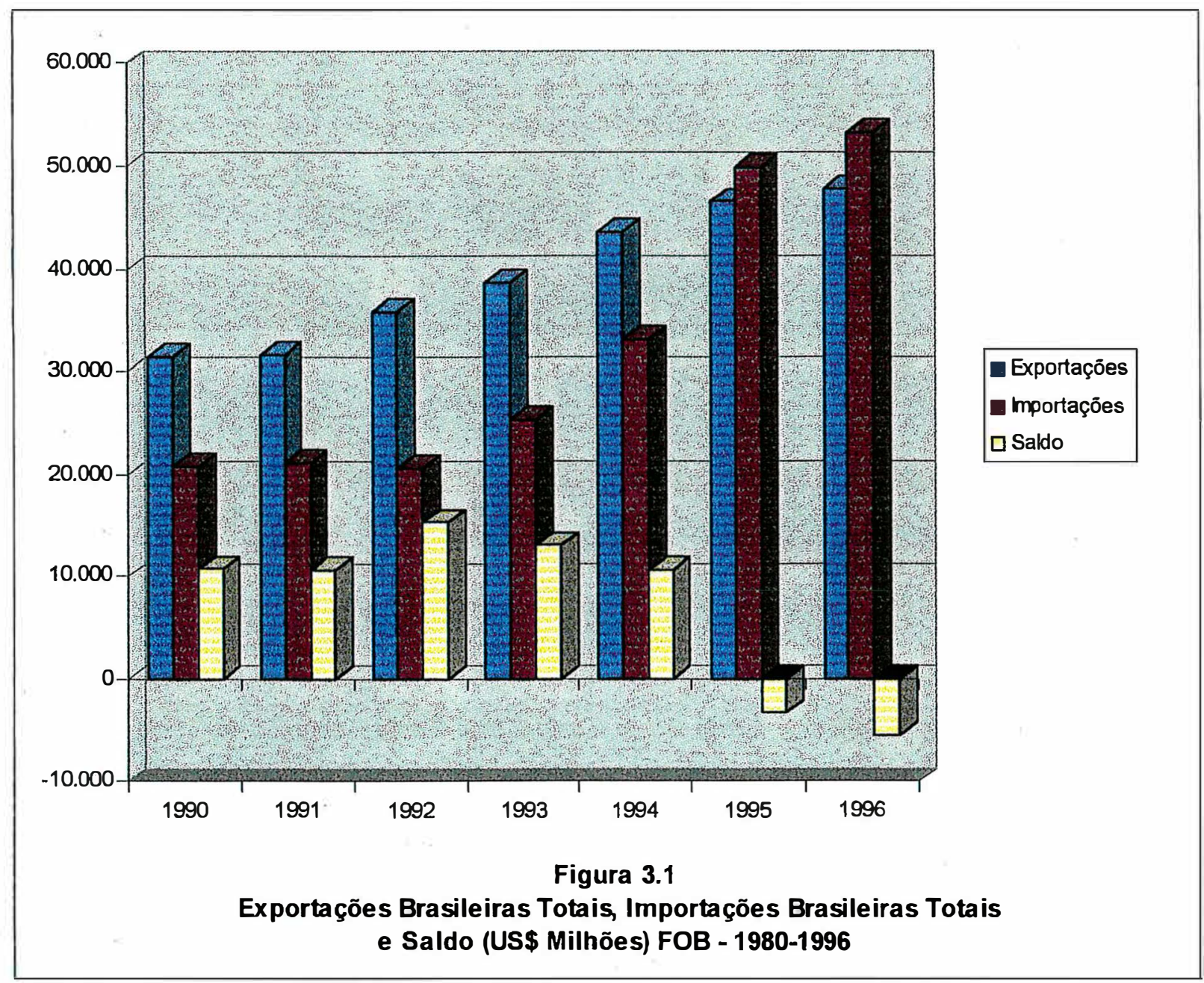

As importações brasileiras atingiram cerca de US $\$ 23$ bilhões em 1980 e US $\$ 53$ bilhões em 1996. A média de importações, que no início de 1980 girava em torno de US\$ 20 bilhões, caiu para US\$ 15 bilhões no periodo de 1983 a 1988, só se recuperando em 1989, mostrando que a economia brasileira era extremamente fechada. Em 1996, tanto em relação às exportações quanto às importações, os dados apontam recordes históricos de desempenho, com valores de US $\$ 47.747$ milhões e US\$ 53.286 milhões, respectivamente, que representam aumentos de $2,67 \%$ e $6,88 \%$ em relação ao ano de 1995, apresentando um saldo negativo de US $\$ 5.539$ milhões. Embora as importações tenham crescido $6,88 \%$ sobre o ano de 1995 , essa taxa de 
crescimento foi bastante inferior à da comparação 95/94 (50,13\%), indicando a progressiva estabilização da corrente importadora após a fase inicial de abertura.

Tabela 3.3 - Brasil: Exportações - Totais por Blocos (US\$ Bilhões) FOB

\begin{tabular}{lccccccccc}
\hline \multicolumn{1}{c}{ Blocos } & 1980 & 1989 & 1990 & 1991 & 1992 & 1993 & 1994 & 1995 & 1996 \\
\hline B. Europeu & 6,8 & 11,4 & 10,5 & 10,4 & 11,1 & 10,4 & 10,6 & 13,4 & 12,1 \\
B. América do Norte & 4,2 & 9,6 & 8,6 & 7,5 & 8,5 & 9,3 & 8,5 & 9,8 & 8,2 \\
B. Asiático & 1,6 & 5,3 & 5 & 5,4 & 5,3 & 5,8 & 5,9 & 7,5 & 5,8 \\
América do Sul & 3 & 3,1 & 2,7 & 4,2 & 6,5 & 8,2 & 7,3 & 9,5 & 9,1 \\
Mercosul & 1,8 & 1,4 & 1,3 & 2,3 & 3,9 & 5,4 & 5,9 & 6,2 & 7,3 \\
Resto do Mundo & 4,6 & 5,1 & 4,5 & 4,2 & 4,7 & 5 & 5,4 & 6,3 & 5,2 \\
Mundo & 20,1 & 34,4 & 31,4 & 31,6 & 35,9 & 38,7 & 43,6 & 46,5 & 47,7 \\
\hline
\end{tabular}

Fonte: Secretaria do Comércio Exterior - SECEX

Em termos de valores globais, o principal parceiro do Brasil continua sendo o Bloco Europeu (UE - União Européia e EFTA - Europen Free Trade Association) destino de US\$12,1 bilhões, ou seja, $26,8 \%$ das exportações totais, aproximadamente. A seguir vem o Bloco América do Norte formado pelos Estados Unidos, Canadá e México, para onde o Brasil exportou cerca de US\$ 8,2 bilhões em 1996, ou seja, 19,3\% das exportações aproximadamente. Para o MERCOSUL foram destinados, em 1996, cerca de US\$ 7,3 bilhões, ou seja $15,3 \%$ das exportações totais. (Ver Tabela 3.3). É importante observar que a participação do MERCOSUL que vinha crescendo rapidamente, não se alterou muito no ano de 1995 em relação a 1994. Em termos de crescimento, as exportações que mais cresceram foram para o Bloco Asiático com $21 \%$. As exportações para o NAFTA apresentaram decréscimo com $-7,1 \%$. As exportações do Brasil para o MERCOSUL apresentaram um crescimento inferior à média de crescimento do Brasil como um todo. 
Tabela 3.4 - Brasil: Importações do Brasil por blocos de origem (US\$ Bilhões) FOB

\begin{tabular}{lcccccccc}
\hline \multicolumn{1}{c}{ Blocos } & 1989 & 1990 & 1991 & 1992 & 1993 & 1994 & 1995 & 1996 \\
\hline B. Europeu & 4,8 & 5,3 & 5,7 & 5,5 & 6,9 & 9,6 & 12,3 & 14,2 \\
B. América do Norte & 4,5 & 5 & 5,7 & 5,7 & 6,9 & 7,9 & 10,4 & 11,3 \\
B. Asiático & 1,6 & 1,7 & 1,8 & 1,7 & 2,9 & 4,8 & 7,9 & 8,1 \\
América do Sul & 3,1 & 3,4 & 3,5 & 3,3 & 4,4 & 6 & 6,8 & 6,3 \\
Mercosul & 2,2 & 2,3 & 2,3 & 2,2 & 3,3 & 4,6 & 6,8 & 8,3 \\
Resto do Mundo & 4,2 & 5,3 & 4,5 & 4,4 & 4,6 & 4,7 & 5,5 & 5,1 \\
Mundo & 18,3 & 20,7 & 21 & 20,6 & 25,2 & 33,1 & 49,7 & 53,3 \\
\hline
\end{tabular}

Fonte SECEX

O principal parceiro comercial do Brasil em 1995, levando-se em consideração as importações continua a ser o Bloco Europeu, de onde o Brasil importou cerca de US $\$ 14,6$ bilhões. Do MERCOSUL o Brasil importou US $\$ 6,8$ bilhões, em 1995. Em termos de crescimento, as importações que mais cresceram foram as do Bloco Asiático (65\%), seguido do NAFTA (57\%) e da América do Sul e do Bloco Europeu com 52\%. (ver Tabela 3.4). A definição dos blocos encontra-se no Apêndice B.

Em 1996, o Brasil exportou US $\$ 47,7$ bilhões, sendo US $\$ 12,2$ bilhões de produtos básicos, e US $\$ 34,7$ bilhões em industrializados. Destes, US $\$ 8,3$ bilhões foram semimanufaturados e US $\$ 26,4$ bilhões manufaturados. O crescimento nos últimos dezesseis anos foi de $41,9 \%$ nos básicos, $204,4 \%$ nos industrializados, sendo $245,8 \%$ nos semimanufaturados e $193,3 \%$ nos manufaturados. (ver Tabela 3.5). 
Tabela 3.5 - Brasil: Exportação por fator agregado (US\$ Bilhões) FOB

\begin{tabular}{cccccc}
\hline Anos & $\begin{array}{c}\text { Básico } \\
\text { (a) }\end{array}$ & $\begin{array}{c}\text { Semimanu } \\
\text { faturado (b) }\end{array}$ & $\begin{array}{c}\text { Manufaturado } \\
\text { (c) }\end{array}$ & $\begin{array}{c}\text { Industrializado } \\
\text { (b+c) }\end{array}$ & Total \\
\hline 1980 & 8,6 & 2,4 & 9 & 11,4 & 20 \\
1990 & 8,7 & 5,1 & 17,2 & 22,3 & 31 \\
1992 & 8,9 & 5,8 & 21,2 & 27 & 35,9 \\
1995 & 11 & 9,1 & 25,6 & 34,7 & 45,7 \\
1996 & 12,2 & 8,3 & 26,4 & 34,7 & 46,9 \\
Taxa Crescimento & 41,9 & 245,8 & 193,3 & & \\
(80/96) & & & & & \\
\hline
\end{tabular}

Fonte: Secretaria do Comércio Exterior - SECEX

As exportações e importações brasileiras também podem ser classificadas por grandes grupos de produtos, segundo as seções da NBM - SH (Normas Brasileiras de Mercadorias - Sistema Harmonizado). As tabelas 3.6 a 3.11 a seguir mostram os grupos de produtos exportados para os diversos blocos econômicos e, também, as importações brasileiras por blocos e por grupos de produtos. Esses dados mostram de maneira mais exata a importância de cada bloco regional, tanto no destino das exportações, quanto na origem das importações do Brasil. As exportações do Brasil para o MERCOSUL se concentraram principalmente em Material de Transporte (26,1\%), Máquinas e Equipamentos (17,1\%), Metais Comuns $(12,4 \%)$ e Produtos Alimentares (10\%), em 1992. (Tabela 3.10).

Em 1995, as exportações do Brasil se concentraram principalmente em Material de Transporte (15\%), Máquinas e Equipamentos (18\%), Químicos (12,28\%), Produtos Alimentares (12,67\%) e Metais (10,35\%), mantendo-se, portanto, o mesmo perfil. As importações do Brasil provenientes do MERCOSUL também apresentaram o mesmo perfil, ou seja, se concentraram em produtos alimentícios $(50,8 \%)$ e $(41,5 \%)$, para os anos de 1991 e 1995, respectivamente. (Tabela 3.10). 
Tabeia 3.6 - Brasil: Exportaçôes (1992) e importações (1991) - Bìoco Europeu

\begin{tabular}{lcccc}
\hline \multicolumn{1}{c}{ Grupos de Produtos } & $\begin{array}{c}\text { Exportações } \\
\text { (US } \$ \text { Milhões) }\end{array}$ & $\begin{array}{c}\text { Importações } \\
\text { (US } \$ \text { Milhões) }\end{array}$ & $\begin{array}{c}\text { Exportações } \\
\text { (\%) }\end{array}$ & $\begin{array}{c}\text { Importações } \\
\text { (\%) }\end{array}$ \\
\hline Alimentos/Fumo/Bebidas & 4.821 & 612 & 43,2 & 10,8 \\
Minerais & 1.214 & 104 & 10,9 & 1,8 \\
Químicos & 484 & 1.337 & 4,3 & 23,7 \\
Plásticos/Borracha & 147 & 215 & 1,3 & 3,8 \\
Caiçados/Couro & 516 & 35 & 4,6 & 0,6 \\
Madeira & 276 & 5 & 2,5 & 0,1 \\
Papel & 576 & 145 & 5,1 & 2,6 \\
Têxtil & 435 & 110 & 3,9 & 2 \\
Minerais não-metálicos/ & 161 & 75 & 1,4 & 1,3 \\
Metais preciosos & 1.170 & 335 & 10,5 & 5,9 \\
Metais Comuns & 739 & 1.990 & 6,6 & 15,2 \\
Máquinas/Equipamentos & 503 & 359 & 4,5 & 6,4 \\
Material de Transporte & 37 & 299 & 0,3 & 5,3 \\
Ótica/Instrumentos & 90 & 31 & 0,8 & 0,5 \\
Outros & 11.162 & 5.650 & 100 & 100 \\
Total & & & & \\
\hline
\end{tabular}

Fonte: Secretaria do Comércio Exterior - SECEX 
Tabela 3.7 - Brasil: Exportações (1992) e Importações (1991) - Bloco América do Norte

\begin{tabular}{lcccc}
\hline \multicolumn{1}{c}{ Grupos de Produtos } & $\begin{array}{c}\text { Exportações } \\
\text { (US\$ Milhões) }\end{array}$ & $\begin{array}{c}\text { Importações } \\
\text { (US\$ Milhões) }\end{array}$ & $\begin{array}{c}\text { Exportações } \\
(\%)\end{array}$ & $\begin{array}{c}\text { Importações } \\
\text { (\%) }\end{array}$ \\
\hline Alimentos/Fumo/Bebidas & 1.622 & 457 & 19,1 & 8,5 \\
Minerais & 415 & 792 & 4,9 & 14 \\
Quimicos & 380 & 948 & 4,5 & 16,8 \\
Plásticos/Borracha & 210 & 306 & 2,5 & 5,4 \\
Calçados/Couro & 1.161 & 16 & 13,6 & 0,3 \\
Madeira & 134 & 1 & 1,6 & 0 \\
Papel & 229 & 206 & 2,7 & 3,7 \\
Têxtil & 426 & 81 & 5 & 1,4 \\
Minerais não-metálicos/ & 135 & 65 & 1,6 & 1,2 \\
Metais preciosos & 1.046 & 204 & 12,3 & 3,6 \\
Metais Comuns & 1.631 & 1763 & 19,2 & 3,6 \\
Máquinas/Equipamentos & 937 & 395 & 11 & 7 \\
Material de Transporte & 88 & 381 & 1 & 6,7 \\
Ótica/Instrumentos & 100 & 15 & 1,2 & 0,3 \\
Outros & 8.514 & $\mathbf{5 . 6 5 3}$ & $\mathbf{1 0 0}$ & $\mathbf{1 0 0}$ \\
Total & & & & \\
\hline
\end{tabular}

Fonte: Secretaria do Comércio Exterior - SECEX

Tabela 3.8 - Brasil: Exportações (1992) e Importações (1991) - Bloco Asiático

\begin{tabular}{|c|c|c|c|c|}
\hline Grupos de Produtos & $\begin{array}{l}\text { Exportações } \\
\text { (US\$ Milhões) }\end{array}$ & $\begin{array}{l}\text { Importações } \\
\text { (US\$ Milhões) }\end{array}$ & $\begin{array}{c}\begin{array}{c}\text { Exportações } \\
(\%)\end{array} \\
\end{array}$ & $\begin{array}{c}\text { Importações } \\
(\%)\end{array}$ \\
\hline Alimentos/Fumo/Bebidas & 871 & 69 & 16,4 & 3,8 \\
\hline Minerais & 934 & 103 & 17,6 & 5,7 \\
\hline Químicos & 268 & 122 & 5 & 6,7 \\
\hline Plásticos/Borracha & 74 & 116 & 1,4 & 6,4 \\
\hline Calçados/Couro & 97 & 29 & 1,8 & 1,6 \\
\hline Madeira & 6 & 1 & 0,1 & 0 \\
\hline Papel & 193 & 9 & 3,6 & 0,5 \\
\hline Têxtil & 140 & 56 & 2,6 & 3,1 \\
\hline $\begin{array}{l}\text { Minerais não-metálicos/ } \\
\text { Metais preciosos }\end{array}$ & 37 & 17 & 0,7 & 0,9 \\
\hline Metais Comuns & 2.347 & 83 & 44,2 & 4,6 \\
\hline Máquinas/Equipamentos & 174 & 940 & 3,3 & 51,9 \\
\hline $\begin{array}{l}\text { Material de Transporte } \\
\text { Ottegfonstrumentos } \\
\text { Total }\end{array}$ & $\begin{array}{c}164 \\
\overline{8} \\
5.314\end{array}$ & $\begin{array}{l}80 \\
1170 \\
1.812\end{array}$ & $\begin{array}{l}3,1 \\
0,2 \\
100\end{array}$ & $\begin{array}{l}4,4 \\
9,8 \\
100\end{array}$ \\
\hline
\end{tabular}

Fonte: Secretaria do Comércio Exterior - SECEX 
Tabela 3.9 - Brasil: Exportações (1992) e Importações (1991) - Bloco América do Sul

\begin{tabular}{lcccc}
\hline \multicolumn{1}{c}{ Grupos de Produtos } & $\begin{array}{c}\text { Exportações } \\
\text { (US\$ Milhões) }\end{array}$ & $\begin{array}{c}\text { Importações } \\
\text { (US\$ Milhões) }\end{array}$ & $\begin{array}{c}\text { Exportações } \\
\text { (\%) }\end{array}$ & $\begin{array}{c}\text { Importações } \\
\text { (\%) }\end{array}$ \\
\hline Alimentos/Fumo/Bebidas & 514 & 1.259 & 7,9 & 36,3 \\
Minerais & 197 & 771 & 3 & 22,3 \\
Químicos & 513 & 247 & 7,9 & 7,1 \\
Plásticos/Borracha & 451 & 98 & 6,9 & 2,8 \\
Calçados/Couro & 84 & 143 & 1,3 & 4,1 \\
Madeira & 34 & 23 & 0,5 & 0,7 \\
Papel & 264 & 73 & 4,1 & 2,1 \\
Têxtil & 397 & 278 & 6,1 & 8 \\
Minerais não-metálicosi & 122 & 35 & 1,9 & 1 \\
Metais preciosos & 999 & 240 & 15,3 & 6,9 \\
Metais Comuns & 1.184 & 168 & 18,2 & 4,8 \\
Máquinas/Equipamentos & 1.627 & 111 & 15 & 3,2 \\
Material de Transporte & 57 & 11 & 0,9 & 0,3 \\
Ótica/Instrumentos & 75 & 8 & 1,1 & 0,2 \\
Outros & $\mathbf{6 . 5 1 7}$ & $\mathbf{3 . 4 6 4}$ & $\mathbf{1 0 0}$ & $\mathbf{1 0 0}$ \\
Total & & &
\end{tabular}

Fonte: Secretaria do Comércio Exterior - SECEX

Tabela 3.10 - Brasil: Exportaçōes e Importaçōes - Bioco MERCOSUL

\begin{tabular}{|c|c|c|c|c|c|c|c|c|}
\hline \multirow[t]{2}{*}{ Grupos de Produtos } & \multicolumn{2}{|c|}{$\begin{array}{c}\text { Exportaçōes (US\$ } \\
\text { Milhōes) }\end{array}$} & \multicolumn{2}{|c|}{$\begin{array}{c}\text { Importaçōes (US } \$ \\
\text { Milhōes) }\end{array}$} & \multicolumn{2}{|c|}{ Exportaçōes (\%) } & \multicolumn{2}{|c|}{ Importaçōes (\%) } \\
\hline & 1992 & 1995 & 1991 & 1995 & 1992 & 1995 & 1991 & 1995 \\
\hline Alimentos/Fumo/Bebidas & 412 & 780 & 1.153 & 2.829 & 10 & 1,27 & 50,8 & 41,5 \\
\hline Minerais & 149 & 243 & 61 & 822 & 3,6 & 3,9 & 2,7 & 12 \\
\hline Químicos & 335 & 756 & 193 & 280 & 8,1 & 12,3 & 8,5 & 4,1 \\
\hline Plásticos/Borracha & 305 & 539 & 78 & 281 & 7,4 & 8,8 & 3,4 & 4,1 \\
\hline Calçados/Couro & 37 & 60 & 139 & 172 & 0,9 & 0,9 & 6,1 & 2,5 \\
\hline Madeira & 25 & 39 & 22 & 43 & 0,6 & 0,6 & 1 & 0,6 \\
\hline Papel & 174 & 296 & 24 & 104 & 4,2 & 4,8 & 1,1 & 1,5 \\
\hline Têxtil & 247 & 303 & 249 & 547 & 6 & 4,9 & 11 & 8 \\
\hline $\begin{array}{l}\text { Minerais não-metálicos/ } \\
\text { Metais preciosos }\end{array}$ & 68 & 122 & 17 & 41 & 1,6 & 1,9 & 0,7 & 0.6 \\
\hline Metais Comuns & 513 & 637 & 49 & 100 & 12,4 & 10,3 & 2,2 & 1,4 \\
\hline Máquinas/Equipamentos & 707 & 1108 & 156 & 471 & 17,1 & 18 & 6,9 & 6,9 \\
\hline Material de Transporte & 1.076 & 1117 & 111 & 1041 & 26,1 & 18,1 & 4,9 & 15,3 \\
\hline Ótica/Instrumentos & 28 & 41 & 9 & 11 & 0,7 & 0,7 & 0,4 & 0,2 \\
\hline Outros & 52 & 88 & 8 & 44 & 1,3 & 1,4 & 0,3 & 0,6 \\
\hline Total & 4.128 & 6154 & 2.268 & 6.821 & 100 & 100 & 100 & 100 \\
\hline
\end{tabular}

Fonte: Secretaria do Comércio Exterior - SECEX 
Tabela 3.11 - Brasil: Exportaçōes (1992) e Importações (1991) - Resto do Mundo

\begin{tabular}{lcccc}
\hline \multicolumn{1}{c}{ Grupos de Produtos } & $\begin{array}{c}\text { Exportações } \\
\text { (US\$ Milhões) }\end{array}$ & $\begin{array}{c}\text { Importações } \\
\text { (US\$ Milhões) }\end{array}$ & $\begin{array}{c}\text { Exportações } \\
\text { (\%) }\end{array}$ & $\begin{array}{c}\text { Importações } \\
\text { (\%) }\end{array}$ \\
\hline Aiimentos/Fumo/Bebidas & 1.580 & 189 & 33,6 & 4,2 \\
Minerais & 478 & 3.547 & 10,2 & 79,5 \\
Químicos & 130 & 392 & 2,8 & 8,8 \\
Plásticos/Borracha & 190 & 5 & 4 & 0,1 \\
Caiçados/Couro & 61 & 21 & 1,3 & 0,5 \\
Madeira & 128 & 1 & 2,7 & 0 \\
Papel & 242 & 13 & 5,2 & 0,3 \\
Têxtil & 93 & 45 & 2 & 1 \\
Minerais não-metálicos/ & 72 & 2 & 1,5 & 0,1 \\
Metais preciosos & 733 & 46 & 15,6 & 1 \\
Metais Comuns & 296 & 110 & 6,3 & 2,5 \\
Máquinas/Equipamentos & 225 & 50 & 4,8 & 1,1 \\
Material de Transporte & 15 & 37 & 0,3 & 0,8 \\
Ótica/Instrumentos & 458 & 3 & 9,7 & 0,1 \\
Outros & 4.700 & 4.462 & 100 & 100 \\
Total & & & & \\
\hline
\end{tabular}

Fonte: Secretaria do Comércio Exterior - SECEX

\section{3 Â Economia dos países do MERCOSUL}

Desde as negociações iniciais para estabelecer o MERCOSUL, em 1991, observou-se um crescimento vigoroso no intercâmbio regional, devido ao processo de desgravação tarifária e a reorientação do comércio entre os países participantes.

O fluxo de comércio Brasil-MERCOSUL entre 1980 e 1985 teve uma queda correspondente a $42,5 \%$, sendo que a redução das exportações brasileiras foi maior $(45,5 \%)$ do que a das importações originárias do MERCOSUL (cerca de 38\%), evidenciando que, no caso das relações do Brasil com os demais países da sub-região, a estratégia de ajustamento externo adotada na primeira metade dos anos 80 determinou uma contribuição negativa ao saldo comercial do pais. Em consequência, 
determinou uma contribuição negativa ao saldo comercial do país. Em consequência, em 1985, não mais que $3,86 \%$ das exportações e $4,96 \%$ das importações brasileiras envolviam os países do MERCOSUL. (Veiga, 1992).

O crescimento começou em 1988 com um salto espetacular em 1991, ano da assinatura do Tratado de Assunção. Em 1985 e 1988 o comércio intra-regional já havia crescido em 54\%, o que - juntamente com a consolidação no mundo, da tendência à formação de espaços regionais de livre comércio e com a percepção "doméstica" da necessidade de mudar o regime de política comercial na direção de uma maior liberalização - configura um quadro de incentivos ao aprofundamento do processo de integração entre Brasil e Argentina. Na verdade, o comércio intra-regional começa a crescer em 1986, em função do aumento do nivel de atividade e do início de processos de desgravação tarifária nesses períodos. (Veiga, 1992).

O intercâmbio em 1993 atingiu US\$ 10.027 bilhões, $142 \%$ a mais do que 1990. Este valor representou $18,5 \%$ do comércio total dos quatro países, bem acima dos 5,5\% registrados em 1985.

No período 1990-1996, as exportações brasileiras para o MERCOSUL cresceram de US $\$ 1.320$ milhões para US $\$ 7.306$ milhões, ou seja, $453,8 \%$, aproximadamente. (Tabela 3.12 e Figura 3.2). Em 1990, a participação das exportações para o MERCOSUL em relação as exportações totais era de $4,2 \%$ passando, em 1996, para 15,3\%. 
TABELA 3.12

Exportações Brasileiras para os Países do Mercosul e Exportações Totais - 1990-96

(US\$ Milhões - FOB)

\begin{tabular}{lccccccc}
\hline Países & 1990 & 1991 & 1992 & 1993 & 1994 & 1995 & 1996 \\
\hline Argentina & 646 & 1455 & 3040 & 3659 & 4136 & 4041 & 5164 \\
Paraguai & 385 & 499 & 543 & 952 & 1057 & 1301 & 1325 \\
Uruguai & 299 & 338 & 518 & 776 & 732 & 812 & 810 \\
MERCOSUL & 1330 & 2292 & 4101 & 5387 & 5925 & 6154 & 7299 \\
Chile & 370 & 674 & 923 & 1108 & 999 & 1210 & 922 \\
Bolivia & 173 & 250 & 333 & 431 & 470 & 530 & 531 \\
Total Geral & 31414 & 31620 & 35793 & 38555 & 43551 & 46506 & 47747 \\
\hline
\end{tabular}

Fonte: Secretaria do Comércio Exterior - SECEX

TABELA 3.13

Importações Brasileiras dos Países do Mercosul e Importações Totais - 1990-96

(US\$ Milhões - FOB)

\begin{tabular}{lccccccc}
\hline Países & 1990 & 1991 & 1992 & 1993 & 1994 & 1995 & 1996 \\
\hline Argentina & 1400 & 1615 & 1732 & 2717 & 3662 & 5481 & 6777 \\
Paraguai & 339 & 220 & 195 & 276 & 352 & 515 & 549 \\
Uruguai & 587 & 434 & 302 & 385 & 569 & 738 & 930 \\
MERCOSUL & 2326 & 2269 & 2229 & 3378 & 4583 & 6734 & 8256 \\
Chile & 368 & 370 & 478 & 436 & 592 & 1094 & 918 \\
Bolivia & 36 & 28 & 15 & 19 & 23 & 28 & 61 \\
Total Geral & 20661 & 21041 & 20554 & 25256 & 33079 & 49858 & 53286 \\
\hline
\end{tabular}

Fonte: Secretaria do Comércio Exterior - SECEX

As importações brasileiras provenientes do MERCOSUL cresceram de US $\$$ 2.326 milhões, em 1990, para US\$ 8.256 milhões, em 1996, ou seja 254,9\%, aproximadamente. (ver Tabela 3.13 e Figura 3.3). 
As tabelas 3.14 a 3.19 apresentam as exportações brasileiras para a Argentina, Paraguai, Uruguai, Chile, Bolívia e Resto do Mundo, respectivamente, no período 1990-1996, em milhões de dólares/FOB, por setores da economia brasileira. Já as tabelas 3.20, 3.21, 3.22, 3.23, 3.24 e 3.25 apresentam as importações brasileiras da Argentina, do Paraguai, do Uruguai, do Chile, da Bolívia e do Resto do Mundo por setores da economia, no período 1990-1996, em milhões de dólares/FOB. 
Tabela 3.14

Exportaçōes Brasileiras para a Argentina - Período 1990-96 - US\$ milhões (FOB)

\begin{tabular}{|c|c|c|c|c|c|c|c|}
\hline Setores & 1990 & 1991 & 1992 & 1993 & 1994 & 1995 & 1996 \\
\hline 1 Agropecuária & 26872 & 68903 & 158625 & 182974 & 168267 & 170307 & 220881 \\
\hline 2 Mineração & 7607 & 7975 & 20873 & 75180 & 92152 & 39002 & 35224 \\
\hline 3 Minerais não Metálicos & 111419 & 111419 & 123025 & 161306 & 164244 & 179681 & 222728 \\
\hline 4 Metalurgia & 155056 & 372973 & 791328 & 911936 & 1066756 & 1016442 & 1280804 \\
\hline 5 Mecânica e Material Elétrico & 39465 & 90776 & 166813 & 226470 & 244255 & 250086 & 295766 \\
\hline 6 Material de Transporte & 65497 & 261059 & 882995 & 910311 & 1000225 & 781094 & 1260832 \\
\hline 7 Madeira e Mobiliário & 3737 & 15043 & 40072 & 68779 & 85519 & 66136 & 80805 \\
\hline 8 Papel e Papelão & 16053 & 79619 & 125898 & 193876 & 170327 & 206848 & 240098 \\
\hline 9 Borracha & 13568 & 56584 & 84876 & 80831 & 94131 & 93231 & 128114 \\
\hline 10 Indústria Química & 134782 & 164512 & 231342 & 306094 & 383605 & 515331 & 527829 \\
\hline 11 Indústria Farmacêutica & 1765 & 3935 & 12098 & 17752 & 25596 & 46446 & 63556 \\
\hline 12 Plásticos & 25934 & 75160 & 117543 & 176814 & 205047 & 239429 & 250872 \\
\hline 13 Indústria Têxtil & 11642 & 50625 & 92497 & 110077 & 111232 & 119422 & 199450 \\
\hline 14 Vestuário & 322 & 17277 & 52004 & 48506 & 65444 & 58403 & 80240 \\
\hline 15 Calçados e Couros & 161 & 3373 & 14143 & 11900 & 18927 & 21934 & 38357 \\
\hline 16 Produtos Alimentares & 28269 & 61294 & 106679 & 144929 & 211918 & 204526 & 220807 \\
\hline 17 Diversos & 3007 & 35643 & 19167 & 31038 & 28211 & 32810 & 18188 \\
\hline 18 Serviços Industriais de U.P. & 0 & 0 & 0 & 0 & 0 & 0 & 0 \\
\hline 19 Construção Civil & 0 & 0 & 0 & 0 & 0 & 0 & 0 \\
\hline 20 Transporte e M. Comércio & 0 & 0 & 0 & 0 & 0 & 0 & 0 \\
\hline 21 Serviços & 0 & 0 & 0 & 0 & 0 & 0 & 0 \\
\hline 22 Total & 646248 & 1452779 & 3039978 & 3658773 & 4135856 & 4041128 & 5164551 \\
\hline
\end{tabular}

Fonte: Secretaria do Comércio Exterior - SECEX - MICT

Tabela 3.15

Exportaçōes Brasileiras para o Paraguai - Periodo 1990-96 - US\$ milhōes (FOB)

\begin{tabular}{|c|c|c|c|c|c|c|c|}
\hline Setores & 1990 & 1991 & 1992 & 1993 & 1994 & 1995 & 1996 \\
\hline 1 Agropecuária & 1036 & 2556 & 4301 & 5279 & 9216 & 16815 & 22991 \\
\hline 2 Mineração & 20772 & 20599 & 23387 & 31401 & 33417 & 38404 & 40599 \\
\hline 3 Minerais não Metálicos & 20731 & 20731 & 24294 & 37103 & 35141 & 46642 & 50816 \\
\hline 4 Metalurgia & 72809 & 106444 & 116990 & 199636 & 217055 & 250587 & 255655 \\
\hline 5 Mecânica e Material Elétrico & 25376 & 31645 & 30121 & 52382 & 60007 & 82199 & 109913 \\
\hline 6 Material de Transporte & 35780 & 34505 & 35355 & 66999 & 91757 & 130000 & 102351 \\
\hline 7 Madeira e Mobiliário & 1539 & 1388 & 2082 & 3778 & 4805 & 7289 & 7607 \\
\hline 8 Papel e Papelão & 11648 & 14080 & 16076 & 30966 & 28168 & 41271 & 38942 \\
\hline 9 Borracha & 33602 & 37624 & 39912 & 77710 & 97944 & 92476 & 114779 \\
\hline 10 Indústria Química & 26765 & 37908 & 44403 & 92190 & 102778 & 129195 & 151455 \\
\hline 11 Indústria Farmacêutica & 10935 & 13593 & 9124 & 15145 & 12993 & 14470 & 15813 \\
\hline 12 Plásticos & 13638 & 17323 & 18112 & 29671 & 36024 & 46522 & 44815 \\
\hline 13 Indústria Têxtil & 20903 & 20285 & 18848 & 34351 & 39139 & 41908 & 39022 \\
\hline 14 Vestuário & 28870 & 41834 & 39957 & 60135 & 41016 & 31674 & 33523 \\
\hline 15 Calçados e Couros & 9665 & 15114 & 14453 & 32812 & 28965 & 29171 & 26093 \\
\hline 16 Produtos Alimentares & 43544 & 74595 & 97627 & 167772 & 200138 & 280528 & 249489 \\
\hline 17 Diversos & 2883 & 5890 & 8267 & 14984 & 18057 & 21579 & 20363 \\
\hline 18 Serviços Industriais de U.P. & 0 & 0 & 0 & 0 & 0 & 0 & \\
\hline 19 Construção Civil & 0 & 0 & 0 & 0 & 0 & 0 & \\
\hline 20 Transporte e M. Comércio & 0 & 0 & 0 & 0 & 0 & 0 & \\
\hline 21 Serviços & 0 & 0 & 0 & 0 & 0 & 0 & . \\
\hline 22 Total & 384700 & 499256 & 543309 & 952314 & 1056620 & 1300730 & 1324226 \\
\hline
\end{tabular}

Fonte: Secretaria do Comércio Exterior - SECEX - MICT 
Tabela 3.16

Exportações Brasileiras para o Uruguai - Periodo 1990-96 - US\$ milhões (FOB)

\begin{tabular}{|c|c|c|c|c|c|c|c|}
\hline Setores & 1990 & 1991 & 1992 & 1993 & 1994 & 1995 & 1996 \\
\hline 1 Agropecuária & 24938 & 27385 & 39175 & 53486 & 54815 & 69177 & 72497 \\
\hline 2 Mineração & 3062 & 351 & 9258 & 62898 & 87190 & 30895 & 11019 \\
\hline 3 Minerais não Metálicos & 3770 & 3770 & 6923 & 12875 & 15991 & 15976 & 15181 \\
\hline 4 Metalurgia & 56178 & 65893 & 105087 & 148782 & 122104 & 142488 & 144894 \\
\hline 5 Mecãnica e Material Elétrico & 31933 & 20195 & 27333 & 43362 & 54391 & 46786 & 42090 \\
\hline 6 Material de Transporte & 62076 & 77894 & 172 & 198454 & 142184 & 205254 & 142715 \\
\hline 7 Madeira e Mobiliário & 5183 & 6479 & 11565 & 24449 & 29619 & 27705 & 24403 \\
\hline 8 Papel e Papelão & 7131 & 13949 & 19084 & 26082 & 25300 & 32274 & 32412 \\
\hline 9 Borracha & 5593 & 7899 & 10939 & 11853 & 12916 & 16204 & 15471 \\
\hline 10 Indústria Química & 30433 & 33016 & 34622 & 41292 & 37029 & 40601 & 59399 \\
\hline 11 Indústria Farmacêutica & 6792 & 9764 & 3129 & 3861 & 5355 & 9997 & 11391 \\
\hline 12 Plásticos & 31684 & 31458 & 33665 & 42681 & 50917 & 51258 & 62684 \\
\hline 13 Indústria Têxtil & 10563 & 15649 & 20794 & 30240 & 25562 & 40546 & 33931 \\
\hline 14 Vestuário & 1033 & 4254 & 10064 & 26823 & 17115 & 18289 & 22335 \\
\hline 15 Calçados e Couros & 5519 & 6707 & 6690 & 8581 & 7683 & 8087 & 11429 \\
\hline 16 Produtos Alimentares & 7075 & 11198 & 16065 & 34360 & 37292 & 49490 & 103258 \\
\hline 17 Diversos & 1673 & 1207 & 3863 & 5727 & 6309 & 5868 & 4865 \\
\hline 18 Serviços Industriais de U.P. & 0 & 0 & 0 & 0 & 0 & 0 & 0 \\
\hline 19 Construção Civil & 0 & 0 & 0 & 0 & 0 & 0 & 0 \\
\hline 20 Transporte e M. Comércio & 0 & 0 & 0 & 0 & 0 & 0 & 0 \\
\hline 21 Serviços & 0 & 0 & 0 & 0 & 0 & 0 & 0 \\
\hline 22 Total & 290094 & 338476 & 358428 & 775806 & 731772 & 811895 & 809974 \\
\hline
\end{tabular}

Fonte: Secretaria do Comércio Exterior - SECEX - MICT

Tabela 3.17

Exportações Brasileiras para o Chile - Período 1990-96 - US\$ milhões (FOB)

\begin{tabular}{|c|c|c|c|c|c|c|c|}
\hline Setores & 1990 & 1991 & 1992 & 1993 & 1994 & 1995 & 1996 \\
\hline $\begin{array}{l}1 \text { Agropecuária } \\
2 \text { Mineração }\end{array}$ & $\begin{array}{r}9494 \\
246\end{array}$ & $\begin{array}{r}14023 \\
5559\end{array}$ & $\begin{array}{r}14735 \\
1799\end{array}$ & $\begin{array}{r}17161 \\
1000\end{array}$ & $\begin{array}{r}27368 \\
1058\end{array}$ & $\begin{array}{r}28159 \\
1001\end{array}$ & $\begin{array}{r}30762 \\
1161\end{array}$ \\
\hline 3 Minerais nāo Metálicos & 9408 & 9408 & 21030 & 28325 & 21466 & 29788 & 29166 \\
\hline 4 Metalurgia & 154878 & 203587 & 275813 & 378686 & 303983 & 376322 & 166476 \\
\hline 5 Mecânica e Material Elétrico & 49766 & 39961 & 46850 & 58642 & 53823 & 74200 & 67488 \\
\hline 6 Material de Transporte & 341 & 187468 & 286242 & 312753 & 260528 & 262831 & 254805 \\
\hline 7 Madeira e Mobiliário & 1184 & 1216 & 1863 & 4457 & 3673 & 8793 & 7929 \\
\hline 8 Papel e Papelão & 21530 & 30531 & 35726 & 38011 & 44920 & 72357 & 38009 \\
\hline 9 Borracha & 15296 & 19100 & 26152 & 34817 & 25998 & 38551 & 35213 \\
\hline 10 Indústria Química & 34147 & 45108 & 57164 & 53476 & 58626 & 84950 & 68873 \\
\hline 11 Indústria Farmacêutica & 1581 & 3224 & 3419 & 5701 & 9021 & 12714 & 13072 \\
\hline 12 Plásticos & 25330 & 33009 & 43535 & 50832 & 55322 & 56292 & 58144 \\
\hline 13 Indústria Têxtil & 21086 & 35761 & 50632 & 52050 & 43786 & 43300 & 43072 \\
\hline 14 Vestuário & 4942 & 7210 & 11456 & 14024 & 12236 & 13039 & 16306 \\
\hline 15 Calçados e Couros & 513 & 2178 & 9493 & 13837 & 16253 & 20746 & 23753 \\
\hline 16 Produtos Alimentares & 14505 & 29262 & 29638 & 30514 & 50443 & 54759 & 59273 \\
\hline 17 Diversos & 5650 & 10648 & 7968 & 14045 & 10309 & 32669 & 8277 \\
\hline 18 Serviços Industriais de U.P. & 0 & 0 & 0 & 0 & 0 & 0 & 0 \\
\hline 19 Construçảo Civil & 0 & 0 & 0 & 0 & 0 & 0 & 0 \\
\hline 20 Transporte e $\mathrm{M}$. Comércio & 0 & 0 & 0 & 0 & 0 & 0 & 0 \\
\hline 21 Serviços & 0 & 0 & 0 & 0 & 0 & 0 & 0 \\
\hline 22 Total & 309568 & 674021 & 923515 & 1108331 & 998813 & 1210471 & 921779 \\
\hline
\end{tabular}

Fonte: Secretaria do Comércio Exterior - SECEX - MICT 
Tabela 3.18

Exportações Brasileiras para a Bolivia - Período 1990-96 - US\$ milhōes (FOB)

\begin{tabular}{|c|c|c|c|c|c|c|c|}
\hline Setores & 1990 & 1991 & 1992 & 1993 & 1994 & 1995 & 1996 \\
\hline 1 Agropecuária & 1012 & 1774 & 1865 & 1860 & 3536 & 5181 & 5355 \\
\hline 2 Mineração & 117 & 402 & 702 & 3221 & 1666 & 770 & 1634 \\
\hline 3 Minerais não Metálicos & 9035 & 9035 & 12666 & 17268 & 18290 & 19431 & 15513 \\
\hline 4 Metalurgia & 49447 & 81040 & 111542 & 135837 & 141668 & 150288 & 137161 \\
\hline 5 Mecânica e Material Elétrico & 19615 & 20525 & 24427 & 29942 & 29187 & 36935 & 58009 \\
\hline 6 Material de Transporte & 14799 & 23539 & 33507 & 32095 & 45577 & 42319 & 42325 \\
\hline 7 Madeira e Mobiliário & 1625 & 2000 & 2605 & 3897 & 4765 & 4218 & 3260 \\
\hline 8 Papel e Papelāo & 7672 & 11834 & 13479 & 15574 & 19026 & 28778 & 17437 \\
\hline 9 Borracha & 4743 & 6460 & 9469 & 15218 & 21823 & 27779 & 34567 \\
\hline 10 Indústria Química & 11919 & 19261 & 23625 & 29314 & 33817 & 37782 & 44850 \\
\hline 11 Indústria Farmacêutica & 491 & 866 & 6051 & 8616 & 8827 & 12983 & 12802 \\
\hline 12 Plásticos & 9283 & 9897 & 11970 & 19403 & 27036 & 24796 & 23353 \\
\hline 13 Indústria Têxtil & 9416 & 14461 & 22075 & 31796 & 32622 & 42743 & 44836 \\
\hline 14 Vestuário & 11235 & 14419 & 17975 & 30349 & 27060 & 26524 & 21720 \\
\hline 15 Calçados e Couros & 13229 & 10580 & 10354 & 14130 & 15588 & 24595 & 26879 \\
\hline 16 Produtos Alimentares & 13033 & 20035 & 26422 & 35539 & 33857 & 38573 & 35300 \\
\hline 17 Diversos & 5595 & 9758 & 3896 & 6589 & 5747 & $\mathfrak{6 3 7 8}$ & 6126 \\
\hline 18 Serviços Industriais de U.P. & 0 & 0 & 0 & 0 & 0 & 0 & 0 \\
\hline 19 Construção Civil & 0 & 0 & 0 & 0 & 0 & 0 & 0 \\
\hline 20 Transporte e $M$. Comércio & 0 & 0 & 0 & 0 & 0 & 0 & 0 \\
\hline 21 Serviços & 0 & 0 & 0 & 0 & 0 & 0 & 0 \\
\hline 22 Total & 179309 & 249870 & 332630 & 430648 & 470092 & 530073 & 531127 \\
\hline
\end{tabular}

Fonte: Secretaria do Comércio Exterior - SECEX - MICT

Tabela 3.19

Exportaçōes Brasileiras para o Resto do Mundo - Periodo 1990-96 - US\$ milhōes (FOB)

\begin{tabular}{|c|c|c|c|c|c|c|c|}
\hline Setores & 1990 & 1991 & 1992 & 1993 & 1994 & 1995 & $\overline{1996}$ \\
\hline 1 Agropecuária & 420016 & 531262 & 3076859 & 3457458 & 4953777 & 4152215 & 4423574 \\
\hline 2 Mineração & 596477 & 597514 & 471962 & 472181 & 576500 & 300744 & 331320 \\
\hline 3 Minerais nāo Metálicos & 2501847 & 2501847 & 2742948 & 2748440 & 2816534 & 3082600 & 3230579 \\
\hline 4 Metalurgia & 5743126 & 6083785 & 7820658 & 8060312 & 8582313 & 9429846 & 9468694 \\
\hline 5 Mecânica e Material Elétrico & 856832 & 811734 & $10678 @ 9$ & 1158122 & 1241263 & 1250746 & 1232105 \\
\hline 6 Material de Transporte & 1433000 & 1040505 & 2201809 & 1912079 & 2265719 & 1913673 & 1917817 \\
\hline 7 Madeira e Mobiliário & 49560 & 263561 & 1392361 & 1720864 & 2083566 & 2835457 & 2338418 \\
\hline 8 Papel e Papelāo & 549408 & 507458 & 526854 & 538586 & 686684 & 874518 & 590657 \\
\hline 9 Borracha & 233772 & $232 \approx 38$ & 300224 & 313053 & 350054 & 426613 & 396241 \\
\hline 10 Indústria Química & 769906 & 658057 & 1159827 & 1187012 & 1246296 & 1478109 & 1597125 \\
\hline 11 Indústria Farmacêutica & 543889 & 63478 & 112948 & 117393 & 129957 & 156159 & 163181 \\
\hline 12 Plásticos & 391952 & $\begin{array}{r}363952 \\
5554819\end{array}$ & 375704 & 386710 & 412210 & 391094 & 294625 \\
\hline 13 Indústria Têxtil & 5580922 & 5554819 & 687397 & 454510 & 543119 & 626611 & 456788 \\
\hline 14 Vestuário & 2766723 & 2444606 & 445671 & 497741 & 453130 & 384286 & 305076 \\
\hline 15 Calçados e Couros & 420949 & 657688 & 1857223 & 2302423 & 2045859 & 2019716 & 2263673 \\
\hline 16 Produtos Alimentares & 6576387 & 6127751 & 5824949 & 5951935 & 7187816 & 8591902 & 9223224 \\
\hline 17 Diversos & 106848 & 19599 & 529793 & 350067 & 573204 & 701693 & 124514 \\
\hline 18 Serviços Industriais de U.P. & 0 & 0 & 0 & 0 & 0 & 0 & 0 \\
\hline 19 Construçāo Civil & 0 & 0 & 0 & 0 & 0 & 0 & 0 \\
\hline 20 Transporte e $\mathrm{M}$. Comércio & 0 & 0 & 0 & 0 & 0 & 0 & 0 \\
\hline 21 Serviços & 0 & 0 & 0 & 0 & 0 & 0 & 0 \\
\hline 22 Total & 29541614 & 28405667 & 30595116 & 31628896 & 36158001 & 38615982 & 38357611 \\
\hline
\end{tabular}

Fonte: Secretaria do Comércio Exterior - SECEX - MICT 
Tabela 3.20

Importações Brasileiras da Argentina - Periodo 1990-9S - US\$ Milhões (FOB)

\begin{tabular}{|c|c|c|c|c|c|c|c|}
\hline Setores & 1990 & 1991 & 1992 & 1993 & 1994 & 1995 & 1996 \\
\hline 1 Agropecuária & 648.660 & 668.236 & 803.061 & 1.010 .877 & 1.271 .694 & 1.731 .904 & 1.968.299 \\
\hline 2 Mineração & 13.462 & 53.131 & 109.994 & 525.447 & 610.159 & 823.552 & 1.232 .513 \\
\hline 3 Minerais não Metáiicos & 111.419 & 111.419 & 9.590 & 11.716 & 16.818 & 31.609 & 24.727 \\
\hline 4 Metalurgia & 152.349 & 172.486 & 156.299 & 211.090 & 232.113 & 426.395 & 479.860 \\
\hline 5 Mecânica e Material Elétrico & 20.540 & 26.466 & 19.461 & 25.681 & 55.916 & 127.310 & 90.236 \\
\hline 6 Material de Transporte & 59.739 & 108.939 & 222.060 & 476.344 & 669.072 & 1.026 .227 & 1.364 .914 \\
\hline 7 Madeira e Mobiliário & 16.676 & 7.862 & 3.137 & 3.245 & 7.853 & 28.614 & 63.305 \\
\hline 8 Papel e Papelão & 36.198 & 15.665 & 8.386 & 7.556 & 10.511 & 81.605 & 99.637 \\
\hline 9 Borracha & 7.727 & 7.091 & 7.221 & 17.386 & 35.466 & 61.007 & 64.364 \\
\hline 10 Indústria Química & 91.916 & 126.665 & 120.665 & 110.573 & 148.136 & 199.264 & 238.223 \\
\hline 11 Indústria Farmacêutica & 2.190 & 1.462 & 3.481 & 8.095 & 18.574 & 35.514 & 74.496 \\
\hline 12 Plásticos & 28.744 & 41.440 & 50.676 & 45.585 & 65.351 & 132.408 & 165.073 \\
\hline 13 Indústria Têxtil & 48.414 & 51.897 & 60.503 & 79.617 & 192.081 & 279.017 & 404.146 \\
\hline 14 Vestuário & 2.150 & 2.061 & 1.289 & 913 & 2.460 & 15.733 & 10.191 \\
\hline 15 Calçados e Couros & 36.338 & 107.724 & 92.974 & 94.080 & 103.607 & 150.530 & 144.662 \\
\hline 16 Produtos Alimentares & 87.312 & 78.482 & 61.392 & 86.722 & 218.034 & 315.000 & 336.000 \\
\hline 17 Diversos & 35.643 & 35.643 & 1.432 & 2.330 & 4.115 & 15.699 & 16.107 \\
\hline 18 Serviços Industriais de U.P. & 0 & 0 & 0 & 0 & 0 & 0 & 0 \\
\hline 19 Construção Civil & 0 & 0 & 0 & 0 & 0 & 0 & 0 \\
\hline 20 Transporte e M. Comércio & 0 & 0 & 0 & 0 & 0 & 0 & 0 \\
\hline 21 Serviços & 0 & 0 & 0 & 0 & 0 & 0 & 0 \\
\hline 22 Total & 1.518 .171 & 1.743 .678 & 1.731 .621 & 2.717 .257 & 3.661 .960 & 5.481 .388 & 6.776 .753 \\
\hline
\end{tabular}

Fonte: Secretaria do Comércio Exterior - SECEX - MICT

Tabela 3.21

Im portações Brasileiras do Paraguai - Período 1990.96 - US\$ Milhões (FOB)

\begin{tabular}{|c|c|c|c|c|c|c|c|}
\hline Setores & 1990 & 1991 & 1992 & 1993 & 1994 & 1995 & 1996 \\
\hline 1 Agropecuária & 142.314 & 38.476 & 18.155 & 18.971 & 110.437 & 219.293 & 231.992 \\
\hline 2 Mineração & 0 & 0 & 0 & 0 & 0 & 0 & 0 \\
\hline 3 Minerais não Metálicos & 20.731 & 20.731 & 0 & 11 & 417 & 171 & 102 \\
\hline 4 Metalurgia & 480 & 207 & 271 & 788 & 8.928 & 2.804 & 6.655 \\
\hline 5 Mecânica e Material Elétrico & 182 & 127 & 29 & 1 & 69 & 386 & 483 \\
\hline 6 Material de Transporte & 642 & 207 & 8 & 31 & 0 & 49 & 27 \\
\hline 7 Madeira e Mobiliário & 30.813 & 20.143 & 23.067 & 31.456 & 29.630 & 32.314 & 29.941 \\
\hline 8 Papel e Papelão & 269 & 351 & 432 & 426 & 604 & 1.759 & 846 \\
\hline 9 Borracha & 30 & 7 & 4 & 8 & 1 & 128 & 363 \\
\hline 10 Indústria Química & 4.310 & 1.533 & 1.004 & 875 & 862 & 2.873 & 2.720 \\
\hline 11 Indústria Fammacêutica & 12 & 0 & 4.661 & 21.542 & 2.844 & 2.149 & 1.183 \\
\hline 12 Plásticos & 7 & 3 & 0 & 5 & 23 & 62 & 146 \\
\hline 13 Indústria Têxtil & 124.989 & 122.084 & 112.664 & 157.665 & 139.417 & 171.749 & 179.964 \\
\hline 14 Vestuário & 5.055 & 5.244 & 1.274 & 1.053 & 2.099 & 4.051 & 4.757 \\
\hline 15 Calçados e Couros & 1.051 & 632 & 1.769 & 11.085 & 9.897 & 4.302 & 1.119 \\
\hline 16 Produtos Alimentares & 1.891 & 9.814 & 31.639 & 31.672 & 47.221 & 72.541 & 89.107 \\
\hline 17 Diversos & 0 & 27 & 17 & 15 & 2 & 14 & 71 \\
\hline 18 Serviços Industriais de U.P. & 0 & 0 & 0 & 0 & 0 & 0 & 0 \\
\hline 19 Construção Civil & 0 & 0 & 0 & 0 & 0 & 0 & 0 \\
\hline 20 Transporte e M. Comércio & 0 & 0 & 0 & 0 & 0 & 0 & 0 \\
\hline 21 Serviços & 0 & 0 & 0 & 0 & 0 & 0 & 0 \\
\hline
\end{tabular}

22 Total

339.509

232.828

194.994

275.604

352.451

514.645

549.476

Fonte: Secretaria do Comércio Exterior - SECEX - MICT 
Tabela 3.22

Importações Brasileiras do Uruguai - Período 1990-96 - US\$ Milhões (FOB)

\begin{tabular}{|c|c|c|c|c|c|c|c|}
\hline Setores & 1990 & 1991 & 1992 & 1993 & 1994 & 1995 & 1996 \\
\hline 1 Agropecuária & 262.573 & 223.705 & 142.005 & 211.757 & 324.742 & 372.502 & 515.838 \\
\hline 2 Mineração & 0 & 12 & 110 & 30 & 0 & 2.104 & 15.106 \\
\hline 3 Minerais não Metálicos & 3.770 & 3.770 & 3.695 & 6.492 & 7.513 & 8.803 & 7.760 \\
\hline 4 Metalurgia & 12.660 & 10.463 & 6.901 & 8.400 & 11.354 & 19.188 & 24.195 \\
\hline 5 Mecânica e Material Elétrico & 5.324 & 4.748 & 2.338 & 2.117 & 5.038 & 8.339 & 6.820 \\
\hline 6 Material de Transporte & 1.219 & 1.441 & 2.856 & 7.632 & 25.984 & 21.439 & 37.133 \\
\hline 7 Madeira e Mobiliário & 1.788 & 899 & 410 & 488 & 7.167 & 15.489 & 14.268 \\
\hline 8 Papel e Papelão & 2.915 & 3.166 & 5.466 & 887 & 546 & 4.596 & 21.857 \\
\hline 9 Borracha & 24.058 & 13.027 & 13.441 & 20.501 & 27.724 & 32.133 & 32.120 \\
\hline 10 Indústria Química & 70.995 & 45.930 & 28.539 & 23.468 & 22.163 & 24.580 & 24.192 \\
\hline 11 Indústria Farmacêutica & 6.983 & 12.400 & 7.805 & 5.419 & 8.414 & 18.305 & 21.209 \\
\hline 12 Plásticos & 17.948 & 16.059 & 20.964 & 21.771 & 25.927 & 56.038 & 55.333 \\
\hline 13 Indústria Têxtil & 28.605 & 26.195 & 25.096 & 28.023 & 35.767 & 51.037 & 44.246 \\
\hline 14 Vestuário & 28.667 & 28.685 & 12.681 & 12.443 & 19.394 & 39.878 & 45.806 \\
\hline 15 Calçados e Couros & 100.445 & 30.679 & 15.990 & 22.385 & 15.851 & 17.202 & 14.105 \\
\hline 16 Produtos Alimentares & 16.944 & 11.499 & 12.115 & 11.952 & 28.809 & 43.846 & 48.186 \\
\hline 17 Diversos & 3.332 & 1.422 & 1.523 & 1.601 & 2.449 & 2.398 & 1.696 \\
\hline 18 Serviços Industriais de U.P. & 0 & 0 & 0 & 0 & 0 & 0 & 0 \\
\hline 19 Construção Civil & 0 & 0 & 0 & 0 & 0 & 0 & 0 \\
\hline 20 Transporte e M. Comércio & 0 & 0 & 0 & 0 & 0 & 0 & 0 \\
\hline 21 Serviços & 0 & 0 & 0 & 0 & 0 & 0 & 0 \\
\hline 22 Total & 592.620 & 436.797 & 301.935 & 385.386 & 568.842 & 737.877 & 929.870 \\
\hline
\end{tabular}

Fonte: Secretaria do Comércio Exterior - SECEX - MICT

Tabela 3.23

Importaçōes Brasileiras do Chile - Período 1990-96 - US\$ Milhões (FOB)

\begin{tabular}{|c|c|c|c|c|c|c|c|}
\hline Setores & 1990 & 1991 & 1992 & 1993 & 1994 & 1995 & 1996 \\
\hline 1 Agropecuária & 110.201 & 75.612 & 41.359 & 59.560 & 71.689 & 153.817 & 165.261 \\
\hline 2 Mineração & 0 & 0 & 0 & 0 & 0 & 858 & 0 \\
\hline 3 Minerais não Metálicos & 9.408 & 9.408 & 153.844 & 135.559 & 144.207 & 265.832 & 194.532 \\
\hline 4 Metalurgia & 216.815 & 211.144 & 169.304 & 120.371 & 152.888 & 318.503 & 251.198 \\
\hline 5 Mecânica e Material Elétrico & 1.548 & 940 & 105 & 489 & 551 & 1.982 & 2.180 \\
\hline 6 Material de Transporte & 3 & 77 & 115 & 912 & 447 & 1.145 & 1.197 \\
\hline 7 Madeira e Mobiliário & 19.101 & 23.975 & 14.359 & 18.762 & 24.363 & 49.110 & 29.657 \\
\hline 8 Papel e Papeläo & 28.511 & 42.558 & 12.634 & 18.849 & 25.728 & 91.610 & 91.995 \\
\hline 9 Borracha & 850 & 335 & 897 & 90 & 1.147 & 4.167 & 886 \\
\hline 10 Indústria Química & 51.867 & 47.081 & 38.474 & 37.964 & 114.692 & 117.852 & 94.587 \\
\hline 11 Indústria Farmacêutica & 16.877 & 15.867 & 1.329 & 1.732 & 1.787 & 2.386 & 1.919 \\
\hline 12 Plásticos & 144 & 224 & 300 & 1.367 & 1.091 & 1.928 & 1.832 \\
\hline 13 Indústria Têxtil & 8.537 & 4.049 & 1.637 & 3.651 & 5.324 & 13.585 & 15.374 \\
\hline 14 Vestuário & 18 & 398 & 34 & 67 & 223 & 1.771 & 3.513 \\
\hline 15 Calçados e Couros & 1.436 & 4.277 & 831 & 904 & 678 & 475 & 950 \\
\hline 16 Produtos Alimentares & 20.719 & 21.653 & 42.695 & 35.305 & 46.556 & 68.467 & 62.861 \\
\hline 17 Diversos & 10 & 39 & 0 & 14 & 265 & 362 & 429 \\
\hline 18 Serviços Industriais de U.P. & 0 & 0 & 0 & 0 & 0 & 0 & 0 \\
\hline 19 Construção Civil & 0 & 0 & 0 & 0 & 0 & 0 & 0 \\
\hline 20 Transporte e $\mathbf{M}$. Comércio & 0 & 0 & 0 & 0 & 0 & 0 & 0 \\
\hline 21 Serviços & 0 & 0 & 0 & 0 & 0 & 0 & 0 \\
\hline 22 Total & 349.298 & 370.222 & 477.917 & 435.596 & 591.636 & 1.093 .850 & 918.371 \\
\hline
\end{tabular}

Fonte: Secretaria do Comércio Exterior - SECEX - MICT 
Tabela 3.24

Importações Brasileiras da Bolivia - Periodo 1990-96 - US\$ Milhões (FOB)

\begin{tabular}{|c|c|c|c|c|c|c|c|}
\hline Setores & 1990 & 1991 & 1992 & 1993 & 1994 & 1995 & 1996 \\
\hline 1 Agropecuária & 13.469 & 4.054 & 4.583 & 805 & 3.750 & 3.750 & 29.694 \\
\hline 2 Mineração & 0 & 0 & 0 & 0 & 0 & 0 & 0 \\
\hline 3 Minerais não Metálicos & 9.035 & 7.035 & 3.080 & 7.057 & 8.874 & 8.874 & 4.907 \\
\hline 4 Metalurgia & 376 & 187 & 114 & 312 & 45 & 45 & 206 \\
\hline 5 Mecânica e Material Elétrico & 0 & 34 & 10 & 0 & 3 & 3 & 100 \\
\hline 6 Material de Transporte & 0 & 24 & 12 & 0 & 0 & 0 & 3 \\
\hline 7 Madeira e Mobiliário & 4.384 & 2.143 & 2.422 & 1.624 & 1.828 & 1.828 & 2.166 \\
\hline 8 Papel e Papelão & 0 & 2 & 98 & 102 & 70 & 70 & 40 \\
\hline 9 Borracha & 1.287 & 418 & 56 & 12 & 44 & 44 & 26 \\
\hline 10 Indústria Química & 404 & 134 & 502 & 629 & 100 & 100 & 88 \\
\hline 11 Indústria Farmacêutica & 0 & 2 & 0 & 0 & 0 & 0 & 0 \\
\hline 12 Plásticos & 0 & 0 & 25 & 0 & 0 & 0 & 0 \\
\hline 13 Indústria Têxtil & 2.732 & 5.479 & 1.387 & 824 & 1.720 & 1.720 & 14.384 \\
\hline 14 Vestuário & 314 & 0 & 192 & 815 & 956 & 956 & 4.157 \\
\hline 15 Calçados e Couros & 2.268 & 939 & 0 & 2.586 & 923 & 923 & 578 \\
\hline 16 Produtos Alimentares & 1.079 & 1.402 & 3.038 & 4.032 & 5.007 & 5.007 & 5.077 \\
\hline 17 Diversos & 0 & 0 & 0 & 4 & 8 & 8 & 18 \\
\hline 18 Serviços Industriais de U.P. & 0 & 0 & 0 & 0 & 0 & 0 & 0 \\
\hline 19 Construção Civil & 0 & 0 & 0 & 0 & 0 & 0 & 0 \\
\hline 20 Transporte e $\mathrm{M}$. Comércio & 0 & 0 & 0 & 0 & 0 & 0 & 0 \\
\hline 21 Serviços & 0 & 0 & 0 & 0 & 0 & 0 & 0 \\
\hline 22 Total & 38.173 & 28.311 & 15.519 & 18.802 & 23.328 & 23.328 & 61.444 \\
\hline
\end{tabular}

Fonte: Secretaria do Comércio Exterior - SECEX - MICT

Tabela 3.25

Importaçōes Brasileiras do Resto do Mundo - Periodo 1990-96 - US\$ Milhões (FOB)

\begin{tabular}{|c|c|c|c|c|c|c|c|}
\hline Setores & 1990 & 1991 & 1992 & 1993 & 1994 & 1995 & 1996 \\
\hline 1 Agropecuária & 521.155 & 719.514 & 662.534 & 740.791 & 1.124 .013 & 1.573 .806 & 1.524.609 \\
\hline 2 Mineração & 4.924 .626 & 4.975 .733 & 4.750 .232 & 4.546 .893 & 4.156.246 & 4.754 .926 & 5.660 .385 \\
\hline 3 Minerais não Metálicos & 289.859 & 300.025 & 267.263 & 262.783 & 353.264 & 512.829 & 593.444 \\
\hline 4 Metalurgia & 5.461 .173 & 5.474 .942 & 5.471 .882 & 4.155 .268 & 6.411 .552 & 9.498 .050 & 10.443 .706 \\
\hline 5 Mecânica e Material Elétrico & 48.853 & 45.539 & 53.402 & 3.430 .729 & 4.812.477 & 7.599.762 & 8.923.388 \\
\hline 6 Material de Transporte & 2.066 .527 & 2.056 .568 & 1.869 .851 & 1.617 .987 & 2.700 .799 & 4.991 .970 & 3.114 .095 \\
\hline 7 Madeira e Mobiliário & 9.885 & 29.143 & 37.840 & 74.424 & 97.752 & 244.189 & 267.657 \\
\hline 8 Papel e Papelão & 227.566 & 239.149 & 263.453 & 328.715 & 446.585 & 1.017.177 & 1.011 .942 \\
\hline 9 Borracha & 247.044 & 265.284 & 255.245 & 320.517 & 465.783 & 710.541 & 795.233 \\
\hline 10 Indústria Química & 2.666 .914 & 2.718.130 & 2.652 .106 & 3.213 .071 & 3.991 .390 & 5.298 .283 & 5.782 .130 \\
\hline 11 Indústria Farmacêutica & 186.751 & 186.995 & 191.656 & 261.048 & 461.269 & 602.306 & 877.920 \\
\hline 12 Plásticos & 420.106 & 417.808 & 387.973 & 584.139 & 711.433 & 1.412 .345 & 1.471.954 \\
\hline 13 Indústria Têxtil & 290.859 & 303.704 & 295.035 & 861.686 & 848.505 & 1.423 .338 & 1.318.370 \\
\hline 14 Vestuário & 7.185 & 7.799 & 28.053 & 37.417 & 90.807 & 321.740 & 320.158 \\
\hline 15 Calçados e Couros & 52.680 & 53.537 & 78.937 & 124.832 & 170.142 & 284.456 & 270.831 \\
\hline 16 Produtos Alimentares & 367.930 & 382.142 & 337.695 & 496.819 & 891.702 & 1.482 .877 & 1.328.272 \\
\hline 17 Diversos & 34.572 & 53.475 & 10.483 & 54.393 & 146.746 & 387.571 & 348.629 \\
\hline 18 Serviços Industriais de U.P. & 0 & 0 & 0 & 0 & 0 & 0 & \\
\hline rução Civil & 0 & 0 & 0 & 0 & 0 & 0 & \\
\hline 20 Transporte e $\mathbf{M}$. Comércio & 0 & 0 & 0 & 0 & 0 & 0 & \\
\hline 21 Serviços & 0 & 0 & 0 & 0 & 0 & 0 & \\
\hline 22 Total & 17.823 .685 & 18.229.487 & 17.613 .640 & 21.111 .512 & 27.880 .465 & 42.116.166 & 44.052 .723 \\
\hline
\end{tabular}

Fonte: Secretaria do Comércio Exterior - SECEX - MICT 


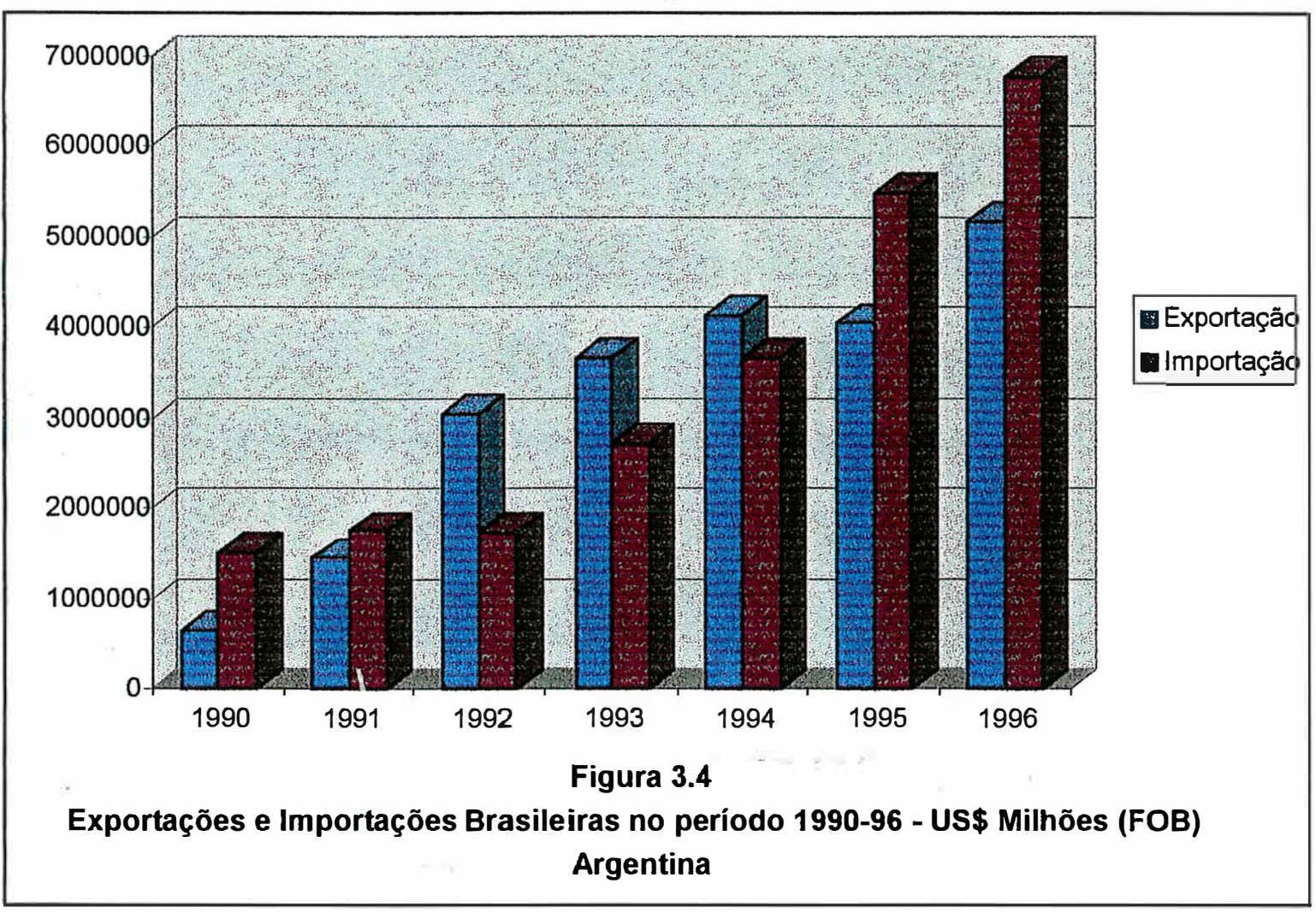



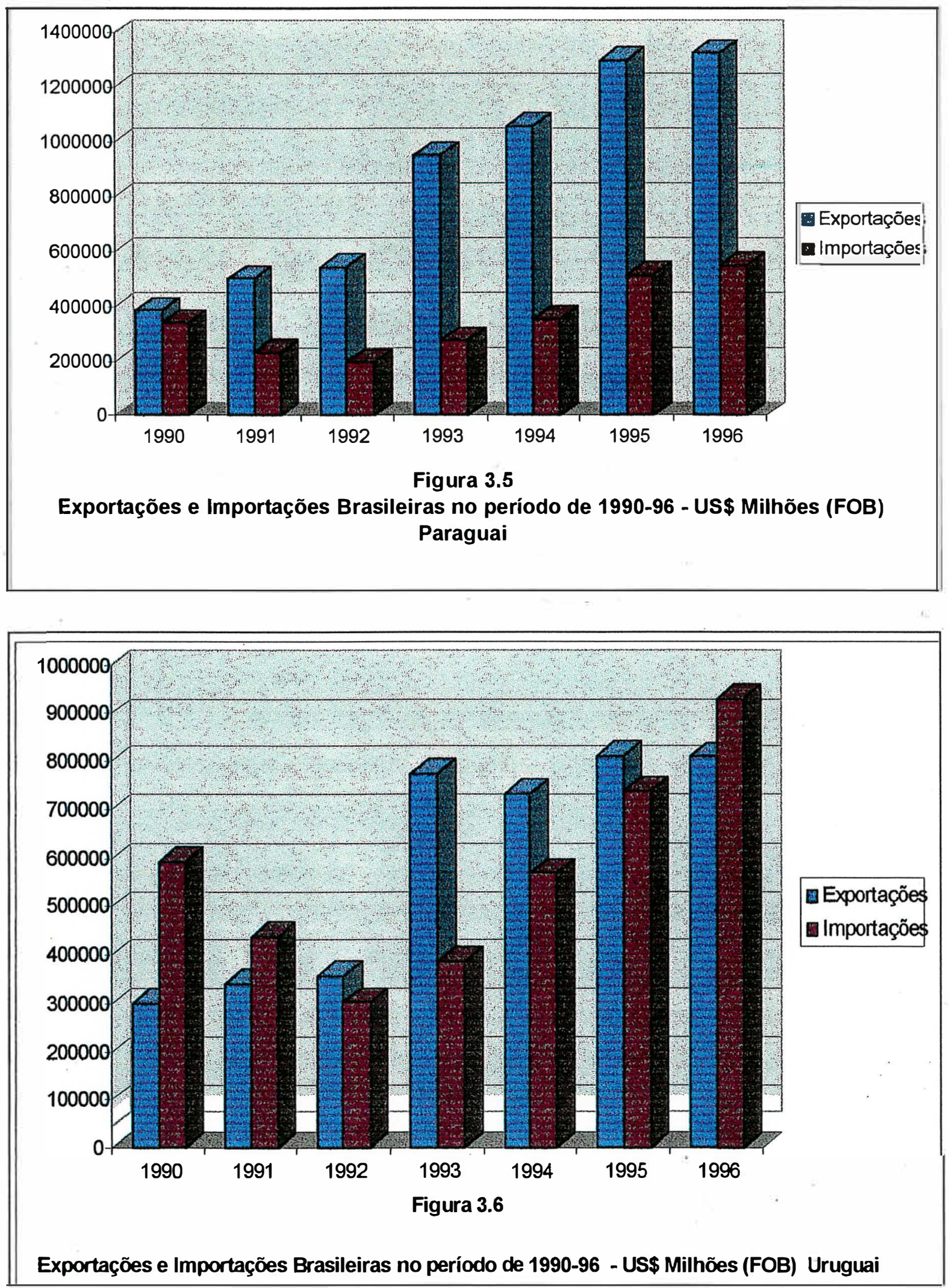

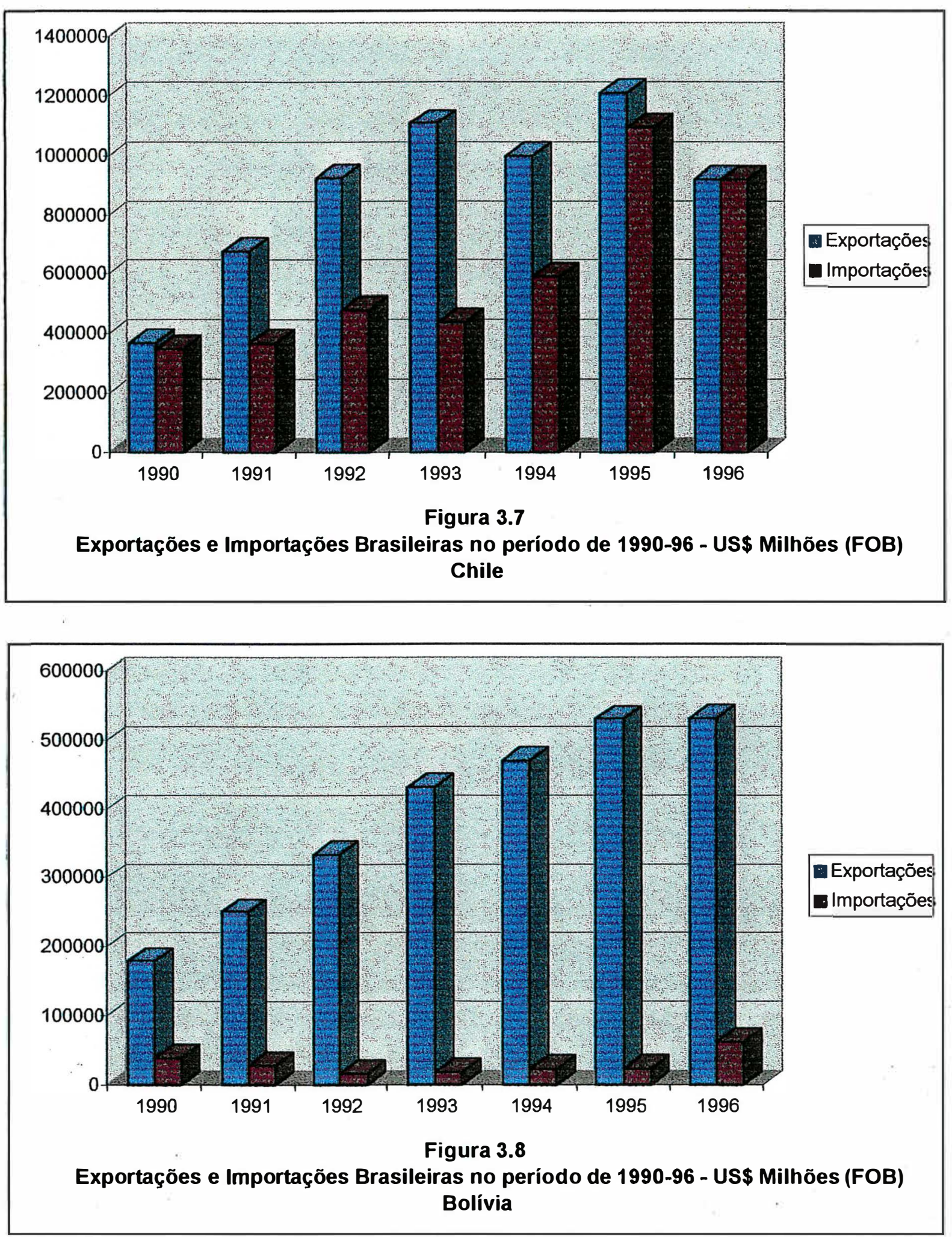


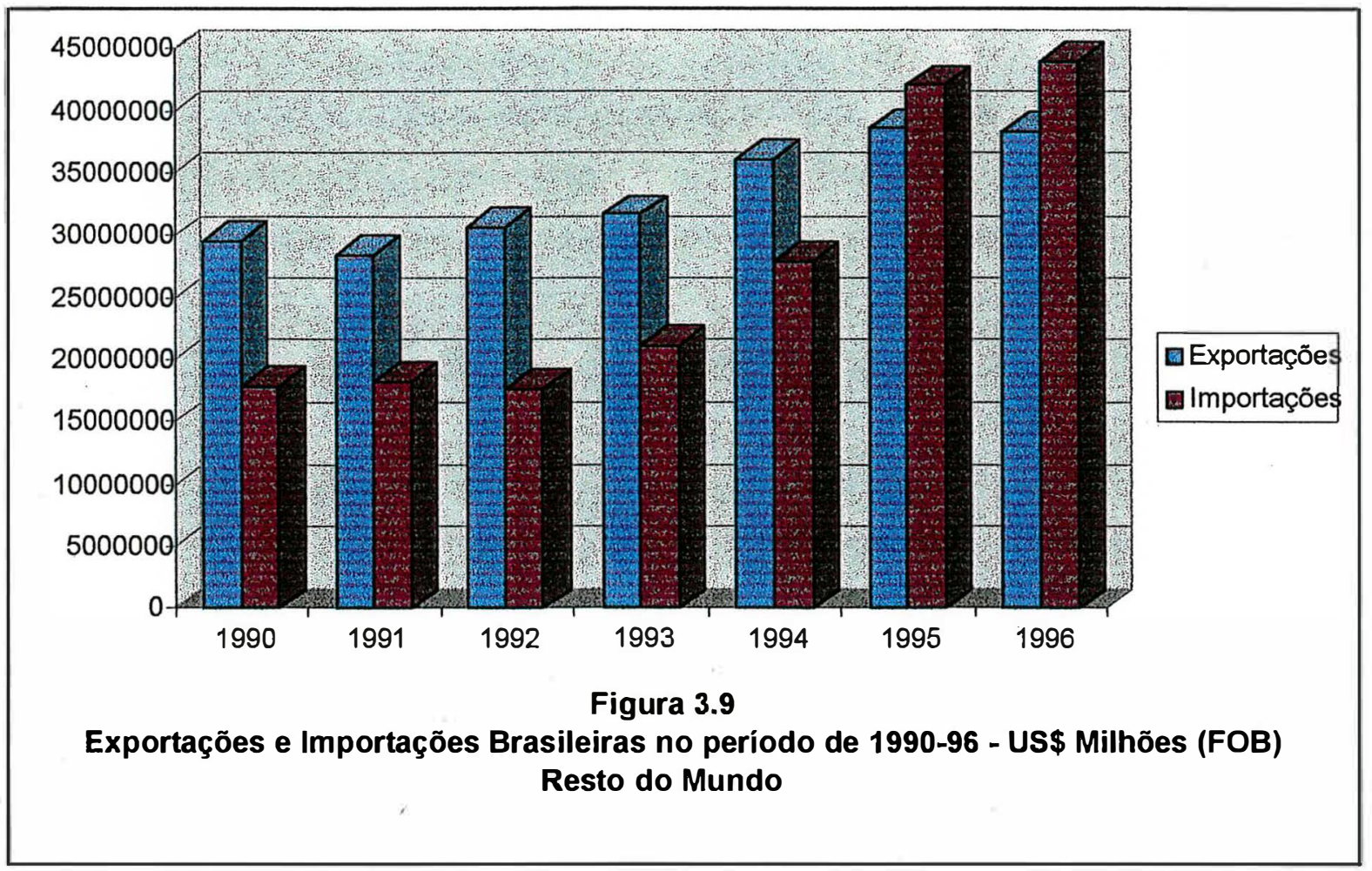

Em 1996, as exportações brasileiras para os países do MERCOSUL, totalizaram US\$ 7.298 milhões, ou seja, 18,6\% superior as exportações realizadas em 1995, quando atingiram US\$ 6.154 milhões. A taxa de expansão registrada, comparando 96/95, é a maior dos últimos três anos: 3,94\% para 95/94 e 9,91\% para 94/93. (verr Tabela 3.12).

Com relação às importações, essas experimentaram um crescimento de $20,75 \%$, ao passarem de US $\$ 6.734$ milhões, em 1995, para US $\$ 8.256$ milhões, em 1996. (ver Tabela 3.13).

Comparando as importações frente às exportações, a balança comercial apresentou saldo negativo de US\$ 958 milhões, em 1996. A corrente de comércio intraregional do Brasil com o MERCOSUL apresentou US $\$ 15.554$ milhões, ou seja, 20,69\% acima do alcançado em 1995. O aumento apresentado em 96/95 evidencia a tendência 
de expansão que o comércio do Brasil no MERCOSUL vem apresentando desde a sua criação em março de 1991, através da assinatura do Tratado de Assunção. De 1990 a 1996 , as trocas comerciais aumentaram, saindo dos US $\$ 3,78$ bilhões em 1990, para US\$15,54 bilhões, em 1996.

As exportações brasileiras para o MERCOSUL cresceram, nestes seis anos de vigência do Acordo, de US $\$ 1,33$ bilhão, em 1990, para US $\$ 7,30$ bilhões, em 1996, ou seja, $448,72 \%$, enquanto que para o resto do mundo passaram, respectivamente, de US $\$ 29,53$ bilhões para US $\$ 38,36$ bilhões.

O crescimento das importações foi fruto da abertura comercial colocada em prática pelo Brasil, a partir de 1990, através da redução das alíquotas do imposto de importação e da eliminação dos normativos administrativos que restringiram as compras externas. Com relação as tarifas, a partir de 1991 deu-se partida em um programa de ampla redução tarifária que, através de sucessivas etapas, baixaria a tarifa média brasileira de 32,3\% em 1990, para 14,2\% em 1994 (Castro \& Souza, 1993). Outro fator que contribuiu para o incremento das importações foi o aumento da demanda interna gerada pela retomada do crescimento da atividade produtiva, especialmente a partir de 1995, com a implantação do plano de estabilização econômica.

As compras brasileiras do MERCOSUL que, em 1990, alcançaram US $\$ 2,45$ bilhões, somaram US $\$ 8,26$ bilhões, em 1996. As importações oriundas do resto do mundo subiram de US $\$ 18,34$ bilhões para US $\$ 45,03$ bilhões. Dos US $\$ 32,63$ bilhões de importações a mais gerados entre 1990 e 1996, apenas 18,20\% originaram-se de compras realizadas no âmbito do MERCOSUL (US $\$ 5,94$ bilhões). As demais importações, ou seja, $81,80 \%$, representando US $\$ 26,69$ bilhões, foram adquiridas de terceiros países. Portanto, a constituição do MERCOSUL não representa fator de restrição às relações comerciais com outros países ou blocos econômicos. 
As exportações para a Argentina, em 1996, somaram US\$ 5.164 milhões correspondendo a $70,77 \%$ do total brasileiro exportado para o MERCOSUL, um crescimento de $27,94 \%$ sobre 1995 . Para o Paraguai, as exportações brasileiras totalizaram US $\$ 1.324$ milhões, em 1996, ou seja, 1,77\% acima dos US $\$ 1.301$ milhões alcançados em 1995. Para o Uruguai, o Brasil exportou, em 1996, cerca de US\$810 milhões, valor semelhante ao ano de 1995, ou seja, US $\$ 812$ milhões. (ver Tabelas $3.14,3.15,3.16$ e Gráficos 3.4, 3.5 e 3.6).

As exportações brasileiras para o Chile totalizaram, em 1996, US\$ 922 milhões contra US\$1.210 milhões, em 1995. Para a Bolívia o Brasil exportou, em 1996, cerca de US $\$ 531$ milhões, valor semelhante ao ano de 1995, ou seja, US\$530 milhões. Para o Resto do Mundo as exportações brasileiras permaneceram constantes nos anos de 1995 e 1996. (ver Tabelas 3.17, 3.18 e 3.19 e Gráficos 3.7, 3.8 e 3.9).

As importações brasileiras do MERCOSUL, em 1996, totalizaram US $\$ 8.258$ milhões, registrando um crescimento de $20,75 \%$ em relação ao ano de 1995 . As compras da Argentina representaram $82,04 \%$ desse total, enquanto Paraguai e Uruguai apresentaram 6,67\% e 11,29\%, respectivamente. (ver Tabelas 3.20, 3.21 e 3.22 e Gráficos 3.4, 3.5 e 3.6).

De 1995 para 1996 as importações brasileiras da Argentina cresceram de US\$ 5.587 milhões para US $\$ 6.775$ milhões, ou seja, $21,16 \%$. As importações brasileiras provenientes do Paraguai cresceram 6,99\%, ou seja, de US $\$ 515$ milhões apresentados em 1995 passou a US\$ 551 milhões, em 1996. Do Uruguai o Brasil importou cerca de US\$ 737 milhões, em 1995, e US\$ 932 milhões em 1996, apresentando uma taxa de crescimento de $26,46 \%$ nesse período. Do Chile o Brasil importou, em 1996, cerca de US\$ 918 milhões, da Bolívia US\$ 61 milhões e do Resto do Mundo US\$ 44.053 milhões (ver Tabelas 3.23, 3.24 e 3.25 e Gráficos 3.7, 3.8 e 3.9). 


\subsubsection{Argentina}

Em relação ao MERCOSUL, ostenta a maior renda per capita, figura no segundo lugar em extensão territorial e é o principal parceiro comercial do Brasil, posição ocupada, também, em relação à América Latina. É tradicional produtora de carne e de cereais. Possui um solo rico em minérios, com destaque para o petróleo. Seus principais parceiros comerciais, além do Brasil, são: Estados Unidos, Chile, Uruguai, Holanda, Alemanha e a Comunidade dos Estados Independentes (CEI). (ver Tabela 3.26).

Tabela 3.26 - Principais Parceiros Comerciais

- ARGENTINA -

(US\$ milhões)

\begin{tabular}{lcccc}
\hline Blocos/Países & \multicolumn{2}{c}{ Exportação } & \multicolumn{2}{c}{ Importação } \\
\cline { 2 - 5 } & 1993 & 1995 & 1993 & 1995 \\
\hline Mercosul & 3.684 & 6.769 & 4.214 & 4.512 \\
Brasil & 2.814 & 5.484 & 3.570 & 4.175 \\
Uruguai & 512 & 654 & $\left(^{*}\right)$ & $\left(^{*}\right)$ \\
Paraguai & 358 & 631 & $\left(^{*}\right)$ & $\left(^{*}\right)$ \\
União Européia & 3.646 & 4.424 & 4.140 & 6.009 \\
Nafta & 1.557 & 2.029 & 4.184 & 4.819 \\
Estados Unidos & 1.264 & 1.773 & 3.859 & 4.177 \\
Demais Países & 293 & 259 & 325 & 642 \\
Japão & $\left(^{*}\right)$ & $\left(^{*}\right)$ & 669 & 711 \\
China & $\left(^{*}\right)$ & $\left(^{*}\right)$ & 215 & 608 \\
Chile & 592 & 1.475 & 706 & 514 \\
\hline
\end{tabular}

Fonte: "The Economist Intelligence Unit (EUI)". Londres, 1996

(*) Dados não disponiveis

Muitas décadas com a economia relativamente fechada levaram o pais à redução do fluxo comercial com o Brasil, o Paraguai e o Uruguai. Com a criação do 
MERCOSUL, em 1991, alargaram-se os horizontes de integração da Argentina com os países vizinhos. A integração vem se desenvolvendo de modo contínuo e progressivo, para a consolidação do Bloco no comércio internacional. Nesta década, as exportações argentinas cresceram e foram lideradas pelos produtos manufaturados de origem agrícola e industrial, e pelos derivados de petróleo. O Brasil se tornou o maior mercado comprador dos produtos argentinos. $O$ estreitamento das relações comerciais com 0 Brasil revela uma atuação ampla das indústrias da região do MERCOSUL. Para os Estados Unidos e para a Europa, as exportações evoluiram moderadamente. As vendas para os países do NAFTA representaram, em 1994, menos da metade do total exportado para os paises do MERCOSUL. Por outro lado, houve aumento da importação de produtos dos mais variados setores industriais, dentre os quais o de bens de capital, que foram adquiridos para modernizar a indústria argentina e representaram, em 1994, cerca de $44 \%$ do total das compras externas. $O$ crescimento das importações, que tem afetado o resultado da balança comercial, decorre da liberalização comercial, da valorização da moeda argentina e do rápido crescimento da demanda interna.

\subsubsection{Brasil}

O Brasil efetua grande parte do comércio exterior do MERCOSUL. Em extensão territorial e em PIB, figura entre os maiores do mundo e ocupa o primeiro lugar em relação ao MERCOSUL e a América Latina. Seus principais parceiros comerciais são: Estados Unidos, Japão, países da União Européia e do MERCOSUL.

As exportações brasileiras são diversificadas, no tocante ao tipo de bens produzidos e de mercados consumidores. A União Européia (UE), os Estados Unidos e o MERCOSUL são os maiores compradores de produtos brasileiros. Nas vendas 
externas, cerca de um terço dos ganhos provém do comércio de produtos primários. A taxa de crescimento das exportações brasileiras é fortemente influenciada pela variação de preços internacionais, os quais, por sua vez, são afetados pela capacidade de o Brasil suprir o mercado externo com determinados produtos. No entanto, o Brasil depende, indiscutivelmente, de investimentos na infra-estrutura industrial para produzir bens mais sofisticados.

De 1980 a 1990, o Brasil obteve excelentes resultados comerciais, que mantiveram os serviços da dívida externa brasileira, haja vista que, no período, o ingresso de capital estrangeiro era reduzido. De 1990 a 1992, houve recuperação do fluxo de capital, reestruturação da dívida brasileira junto a banqueiros externos e redução das importações. (ver Tabela 3.27).

Tabela 3.27 - Principais Parceiros Comerciais

- BRASIL -

(US\$ milhões)

\begin{tabular}{lcccc}
\hline \multirow{2}{*}{ Blocos/Países } & \multicolumn{2}{c}{ Exportação } & \multicolumn{2}{c}{ Importação } \\
\cline { 2 - 5 } & $\mathbf{1 9 9 5}$ & $\mathbf{1 9 9 6}$ & $\mathbf{1 9 9 5}$ & $\mathbf{1 9 9 6}$ \\
\hline União Européia & 12.911 & 12.836 & 13.798 & 14.088 \\
Holanda & 2.917 & 3.548 & 595 & 568 \\
Alemanha & 2.158 & 2.082 & 4.766 & 4.775 \\
Itália & 1.713 & 1.530 & 2.864 & 2.910 \\
Reino Unido & 1.325 & 1.323 & 988 & 1.245 \\
França & 1.038 & 912 & 1.380 & 1.341 \\
Demais Países & 3.760 & 3.441 & 3.205 & 3.249 \\
Estados Unidos & 8.682 & 9.182 & 10.385 & 11.682 \\
Argentina & 4.041 & 5.170 & 5.587 & 6.774 \\
Japão & 3.101 & 3.047 & 3.297 & 2.756 \\
China & 1.203 & 1.113 & 1.041 & 1.128 \\
\hline
\end{tabular}

Fonte: MICT/SECEX 


\subsubsection{Paraguai}

O Paraguai é o menor país do MERCOSUL em renda per capita. Após o déficit comercial que se prolongou pela década de oitenta, a alta do preço da soja e do algodão influiu no superávit registrado em 1989. Entretanto, em decorrência da liberalização das importações, a balança comercial paraguaia voltou a registrar, a partir de 1990, déficit comercial crescente, que chegou, em 1993, a cerca de US\$1 bilhão. Nos anos 80, a soja e o algodão foram substituídos por produtos alimentícios e por madeira, que passaram a ter maior importância nos resultados das vendas externas, a ponto de ocuparem, em 1990, a terceira posição entre os produtos mais vendidos ao exterior. Em 1993, a soja suplantou o algodão e foi o principal produto de exportação paraguaia. Nas importações predominam maquinaria, veículos, peças e acessórios, combustível, bebidas alcoólicas e fumo, muitos dos quais são vendidos ao mercado externo.

Em 1994, os Estados Unidos ocuparam o quarto lugar em exportações e o terceiro em importações. A criação do MERCOSUL favoreceu o comércio do Paraguai com a Argentina e o Brasil, que são os maiores mercados supridores do país. A Associação Latino-Americana de Integração (ALADI) dispensa ao Paraguai tratamento especial, com vistas a incrementar o comércio entre ele e os países latino-americanos. Os resultados comerciais junto aos parceiros do MERCOSUL tem se apresentado negativos. Em 1994, o déficit atingiu cerca de US\$ 400 milhões. (ver Tabela 3.28). 
Tabela 3.28 - Principais Parceiros Comerciais

- PARAGUAI -

US\$ Milhões

\begin{tabular}{lcccc}
\hline \multirow{2}{*}{ Países } & \multicolumn{2}{c}{ Exportação (\%) } & \multicolumn{2}{c}{ Importação (\%) } \\
\cline { 2 - 5 } & $\mathbf{1 9 9 3}$ & $\mathbf{1 9 9 5}$ & $\mathbf{1 9 9 3}$ & $\mathbf{1 9 9 5}$ \\
\hline Brasil & 23 & 31,1 & 10,3 & 25,9 \\
Argentina & 6,6 & 9,3 & 14,2 & 11,4 \\
Estados Unidos & 3,7 & 9 & 12,4 & 9 \\
Holanda & 13,3 & 26,2 & $\left(^{*}\right)$ & $\left(^{*}\right)$ \\
Chile & 2,4 & 6,3 & $\left(^{*}\right)$ & $\left(^{*}\right)$ \\
Alemanha & $\left(^{*}\right)$ & $\left(^{*}\right)$ & 7,4 & 0,7 \\
Reino Unido & $\left(^{*}\right)$ & $\left(^{*}\right)$ & 4,6 & 3,5 \\
\hline
\end{tabular}

Fonte: "The Economist Intelligence Unit (EIU)" Londres, 1996

\subsubsection{Uruguai}

Em relação ao MERCOSUL, é a menor nação e uma das maiores rendas per capita. No período de 1987 a 1994, as vendas externas uruguaias cresceram à taxa anual média de $7,3 \%$. Contudo, os produtos tradicionais na exportação, tais como carne e lã, vêm apresentado desempenho menos expressivo do que os não tradicionais, em decorrência da variação do preço dos produtos e do volume da produção. Ainda assim, os produtos tradicionais têm participação significativa no total das vendas ao exterior. $O$ volume de importações foi aumentando gradativamente e atingiu a culminância em 1994, ano em que se registrou o dobro do valor obtido em 1990. O resultado decorreu do déficit comercial de 1991, que cresceu de modo acentuado, nos três anos seguintes. As causas principais foram o aumento do consumo de produtos uruguaios por turistas argentinos - motivados pelo fortalecimento da moeda argentina - e o consumo interno de produtos duráveis - especialmente de automóveis - e de não duráveis - cujo volume das importações, de 1992 a 1994, elevou-se a 4,8\%, aproximadamente.(ver Tabela 3.29). 
Tabela 3.29 - Principais Parceiros Comerciais

- URUGUAI -

US\$ Milhões

\begin{tabular}{ccccc}
\hline \multirow{2}{*}{ Países } & \multicolumn{2}{c}{ Exportação (\%) } & \multicolumn{2}{c}{ Importação (\%) } \\
\cline { 2 - 5 } & $\mathbf{1 9 8 9}$ & $\mathbf{1 9 9 4}$ & $\mathbf{1 9 8 9}$ & $\mathbf{1 9 9 4}$ \\
\hline Mercosul & 32,9 & $\mathbf{4 7}$ & $\mathbf{4 3 , 3}$ & $\mathbf{4 9 , 4}$ \\
Alemanha & 4,9 & 20 & 15,6 & 23,5 \\
Brasil & 27,7 & 25,7 & 26,6 & $\mathbf{2 5 , 6}$ \\
Paraguai & 93 & 1,3 & 1,1 & 0,3 \\
União Européia & 22,7 & 19,9 & 18,8 & 19,2 \\
Estados Unidos & 11,1 & 6,8 & 9,4 & 9,4 \\
\hline
\end{tabular}

Fonte: "The Economist Intelligence Unit (EIU)" Londres, 1996.

Em resumo, a análise apresentada neste capítulo permite concluir que em relação ao destino das exportações brasileiras, os principais parceiros do Brasil foram - Bloco Europeu, o Bloco América do Norte e a América do Sul, no período de 19901994. Já para as importações, os principais parceiros do Brasil foram o Bloco América do Norte e o Bloco Europeu, com participação estável, no período analisado.

A participação do MERCOSUL nas exportações brasileiras aumentou de $7,3 \%$ para 13,6\% entre 1991 e 1994. Esse resultado deve-se em grande parte ao intercâmbio comercial com a Argentina, que se tornou o segundo mercado de destino das exportações brasileiras durante a primeira metade da década de 90. As exportações brasileiras para a Argentina explicam cerca de $70 \%$ das vendas externas brasileiras para o MERCOSUL.

Cabe ressaltar que a integração econômica entre Brasil, Argentina, Paraguai e Uruguai apresentou resultados positivos de 1990 a 1996 no sentido de que expandiu o intercâmbio comercial. Em relação à Argentina, principal parceiro do Brasil no MERCOSUL, a geração de significativos déficits do Brasil nos anos de 1995 e 1996 pode levantar dúvidas quanto à distribuição dos custos e dos benefícios da integração. 


\section{REFERENCIAL TEÓRICO E FONTE DOS DADOS}

\section{1 introdução}

A análise do insumo-produto é uma técnica que quantifica a interdependência dos setores produtivos de uma economia, marcando as transferências de bens de produção de um setor a outro, e de modelos que pretendem detalhar as implicações de determinada demanda ou de determinada oferta. Tem sua origem no trabalho de Wassily W. Leontief (1951) com a construção das primeiras matrizes de insumoproduto para os Estados Unidos.

Segundo Leontief, o modelo de insumo-produto é "... uma tentativa de aplicar a teoria econômica do equilíbrio geral - ou meihor, interdependência geral - a um estudo empírico das interrelações entre as diferentes partes de uma economia...". (Leontief, 1960, p.3).

Neste modelo formulado por Leontief, chamado modelo "fechado", todas as "indústrias" eram tratadas de maneira idêntica, inclusive o setor correspondente às familias. Os itens que aparecem no vetor de demanda final eram interpretados como representando os insumos absorvidos pelas famílias, necessários para que estas fornecessem os serviços de mão-de-obra, capital, etc. Os serviços fornecidos pelo setor final eram tratados de forma equivalente aos insumos de qualquer outro setor. 
Pode ser considerado como uma simplificação do sistema Walrasiano, de maneira a tornar possivel a derivação de um conjunto de parâmetros a partir de uma única observação das transações intersetoriais ocorridas numa economia num determinado período.

As Tabelas de insumo-Produto ou Tabela de Relações Intersetoriais "... mostram o fluxo real de mercadorias e serviços que sai de uma indústria para outras, das indústrias para as familias e das famílias para as indústrias ...". (Leontief, op cit, p.4). "O princípio deste método de descrição estatística é bastante simples. Cada "indústria" (incluindo as famílias) é tratada como uma única entidade contábil - comparável a um "país" nas estatísticas oficiais de comércio exterior - com as vendas registradas em um lado desta conta de comércio e as compras no outro. Como no comércio entre países, as vendas de uma indústria são as compras no outro. Registrando a conta de vendas e compras de todas as indústrias individuais em uma grande tabela, conseguimos uma visão completa da estrutura da economia nacional como um todo". (Leontief, op cit, p.5).

Assim, a tabela de insumo-produto constitui uma descrição estatística dos usos de insumos e das produções dos diferentes setores que compõem um sistema econômico, em determinado período de tempo. Na tabela de insumo-produto, o sistema econômico aparece dividido em vários setores produtivos.

Cada linha da tabela registra as receitas (ou seja, os produtos e serviços) de uma determinada indústria (ou das famílias). Cada coluna da tabela apresenta os mesmos itens vistos como despesa, ou seja, como os insumos adquiridos são utilizados pelas diferentes indústrias (ou pelas famílias). Para cada indústria catalogada na tabela, ocorre a igualdade entre a receita obtida com as vendas e o gasto total dos bens e serviços adquiridos de outras indústrias e do setor final.

A tabela de insumo-produto apresenta um número correspondente de linhas uma para cada indústria - e de colunas, também, uma para cada indústria. Cada linha mostra para onde irá o produto de uma indústria; cada coluna mostrará a quantidade 
de insumo que cada indústria empregou. Essa tabela e suas variações são utilizadas para se analisar o impacto que a demanda de um valor extra de certo tipo de produto pode causar na economia.

Leontief elaborou um segundo modelo "aberto" onde a demanda final é considerada como autônoma e determinada fora do modelo. A Tabela de insumoProduto construída segundo as hipóteses do modelo aberto possui uma ciara distinção entre a linha e coluna correspondentes ao setor final e aquelas referentes aos demais setores: as colunas e linhas correspondentes às indústrias $1,2, \ldots, n-1$ constituem o setor "interindustrial" da Tabela e a coluna e linha restantes formam, como já vimos, o setor "demanda final". De acordo com essa classificação, os produtos são divididos, respectivamente, em "intermediários" e "finais", e os insumos em "produzidos" e "primários". No caso do modelo aberto de insumo-produto, os serviços fornecidos pelas familias, o capital e a terra agricola são considerados como insumos primários, todos os demais insumos são produzidos e suas quantidades fazem parte da solução do modelo.

Segundo FIBGE (1987), a tabela de fluxos intersetoriais detalha a composição e a origem dos fluxxos dos bens e serviços (produção e importação), seus destinos (consumo intermediário, consumo pessoal e do governo, exportação e formação de capital) e a renda gerada nesse processo (sua distribuição primária e setorial). A distinção entre o modelo de insumo-produto e a tabela de insumo-produto deve-se ao fato de o modelo de insumo-produto constituir um esquema analítico formado por um sistema de equações lineares simultâneas (Haddad, 1976).

O modelo de insumo-produto tem por base o modelo tradicional de Leontief e é composto por três componentes básicos: tabela de fluxos intersetoriais, coeficientes técnicos e efeitos diretos e indiretos. Fontenele e Silva (1990) diz que o modelo de insumo-produto constitui-se, basicamente, de dois conjuntos de relações fundamentais, isto é, de "um conjunto de identidades contábeis, indicando qual a parceia da produção de cada setor, em que se divide a economia, é destinada à utilização final" (isto é, tabela de fluxos intersetoriais); e "um conjunto de relações estruturais, indicando a 
quantidade de insumo que o setor $i$ fornece ao setor $j$, por unidade de produção do setor $j$ (coeficientes técnicos). Além disso, a análise de insumo-produto descreve a interação de três elementos do sistema econômico: demanda final, necessidades de insumos de cada setor e seu produto bruto, sendo um dos principais propósitos analíticos do modelo de insumo-produto a determinação dos efeitos que mudanças especificas na demanda final têm sobre a produção bruta, dada a matriz de coeficientes técnicos.

Os coeficientes técnicos representam as quantidades necessárias de insumos para a produção total de uma unidade de produto em cada setor. Os coeficientes de interdependência indicam a mudança total na demanda de insumos decorrente de alteração de uma unidade de vaior na demanda final.

As teorias elaboradas sobre as estatisticas de insumo-produto entre outras utilizações: a) indicam a expansão requerida em áreas de importância econômica, a longo prazo, servindo como subsidio para os órgãos governamentais orientarem seus investimentos e garantirem um crescimento econômico adequado; b) ajudam a determinar a viabilidade da obtenção de qualquer nivel de produção, comparando os custos de produção de vários niveis e dando a conhecer os insumos requeridos para se atingir determinado nivel; c) permitem prever o impacto que uma variação no padrão de exportação provocará no nivel de produção, bem como as variações nos requisitos de importação, decorrentes de alterações na estrutura da demanda; d) facilitam a investigação do resultado de politicas de desenvolvimento regional, em contraposição ao crescimento e à variação nacional; e) facilitam o acompanhamento do impacto de uma variação dos preços dos fatores sobre o nível e a estrutura do preço dos produtos finais. Também são utilizados para acompanhar o impacto das variações de produtividade sobre a estrutura da economia e o nivel de produção.

Os modelos de insumo-produto contém um número considerável de suposições simplificadoras, tais como os retornos constantes à escala de produção (independentes da escala de produção) e a ausência de substituição entre os produtos (demanda final) e entre os insumos (demanda intermediária). 
A solução do modelo de insumo-produto permite gerar os multiplicadores de produto, renda, emprego, bem como os impactos de mudanças na produção de cada setor decorrentes de uma mudança específica na demanda final. O multiplicador do produto mede a mudança total na produção de todos os setores decorrente da mudança de uma unidade no valor da demanda final de cada produto do setor em consideração. O multiplicador de produto para a indústria $i$ mede a soma das necessidades diretas e indiretas de todos os setores para fornecer uma unidade adicional do produto $i$ à demanda final.

Âs dificuldades com relação à construção da Tabela de Insumo-Produto são relacionadas a seguir:

a) o problema da agregação: em princípio, a Tabela de Insumo-Produto poderia listar individualmente todas as empresas e todas as familias existentes num determinado país; no entanto, caso uma tabela como essa pudesse ser construída seria impossivel manuseá-la. A agregação das unidades econômicas catalogadas na Tabela pode ser baseada em vários principios. As empresas poderiam ser classificadas de acordo com a região em que se localizassem. Como os modelos que utilizam as relações básicas de insumoproduto são classificados em estáticos ou dinâmicos, essa tipologia torna-se genérica quando se deseja visualizar a estrutura de construção das matrizes inter-regionais. Assim, passa-se a classificar os diferentes modelos levandose em consideração a natureza das informações estatísticas utilizadas e os métodos de estimação das matrizes. Porém, a classificação é feita de acordo com o tipo de produto. Cada indústria é associada a um produto ou um grupo de produtos considerados primários a ela. As empresas são classificadas entre as diferentes indústrias de acordo com o produto cujo valor da produção constitua a maior parte da receita da empresa;

b) o setor final: na coluna do setor final geralmente são registrados os fluxos de bens e serviços que vão não só para as famílias, mas também para o Governo, o resto do mundo, a acumulação bruta de estoques e a formação 
bruta de capital. Na linha do valor adicionado, são registrados, além dos pagamentos feitos às famílias, os gastos com impostos, a exaustão dos estoques $e$ as provisões feitas para depreciação. $\dot{E}$ importante que as variações de estoques sejam registradas no setor de demanda final da Tabela. isso acontece porque no modelo de insumo-produto devem aparecer apenas os valores de cada mercadoria efetivamente usada na produção; no entanto, as estatísticas primárias geralmente se referem aos valores das mercadorias e estes podem não ser iguais aos montantes efetivamente utilizados.

c) "indústrias" peculiares: na prática, o setor comercial recebe quase todo o produto de todas as indústrias e o repassa ao setor final ou às próprias indústrias. Porém, estas transações não correspondem a relações técnicas, Por isso, na Tabela, os fluxos de mercadorias aparecem provindos das indústrias diretamente para os setores que as absorvem. Dessa forma, a linha correspondente ao setor comercial registra apenas o pagamento que cada indústria realiza em troca dos serviços de intermediação entre o produtor e o comprador. Em contrapartida, a coluna correspondente ao setor comercial registra apenas as mercadorias que ele efetivamente absorve. 0 setor de transportes recebe um tratamento análogo àquele referente ao setor comercial.

O modelo de insumo-produto procura descrever a estrutura produtiva da economia e mais especificamente, sua estrutura tecnológica. A característica fundamental do modelo é que ele é formulado de uma maneira tal que seus parâmetros podem ser medidos estatisticamente e, dessa forma, ele pode fornecer respostas para problemas econômicos concretos. Os dados empíricos do modelo estão contidos na Tabela de Relações Intersetoriais. O modelo de insumo-produto é um sistema linear. Essa hipótese se reflete no fato de que os elementos que entram no modelo como os insumos necessários à produção de cada unidade de um determinado produto são constantes. Além disso, a linearidade é o resultado da combinação de duas hipóteses: 
a homogeneidade e a aditividade. Outra hipótese importante feita no modelo de insumo-produto é que cada mercadoria é fornecida por uma única indústria e, reciprocamente, cada indústria produz apenas uma mercadoria. Na realidade, observase que cada mercadoria é fornecida por mais de uma indústria e, também, que cada indústria produz mais do que uma mercadoria.

\subsection{Referencial teórico}

\subsubsection{Representação aigébrica do modelo}

Inicialmente, a partir da tabela de fluxos intersetoriais (identidades contábeis) e considerando a demanda final pelo produto da indústria $i\left(Y_{i}\right)$, a produção total da indústria $i\left(X_{i}\right)$ e os valores monetários do fluxo do setor $i$ para o setor $j\left(z_{i j}\right)$, pode-se definir um sistema de equações lineares simultâneas, cujos parâmetros são estimados empiricamente. Considere-se a seguinte identidade, na qual a economia é dividida em $n$ setores:

$$
X_{i}=z_{i 1}+z_{i 2}+\ldots+z_{i n}+Y_{i} \quad i=1,2, \ldots n
$$

Como os valores de insumo $i$ consumidos pelo setor $j$ são diretamente proporcionais à produção do setor $j$, obtêm-se os coeficientes técnicos de produção (ou coeficientes de efeitos diretos), como se segue:

$$
a_{i j}=z_{i j} / x_{j} \quad i=1,2, \ldots n
$$

Considerando que a equação (2) pode ser descrita da seguinte forma:

$$
z_{i j}=a_{i j} x_{j} \quad i=1,2, \ldots n
$$


então pode-se modificar a equação (1) como se segue:

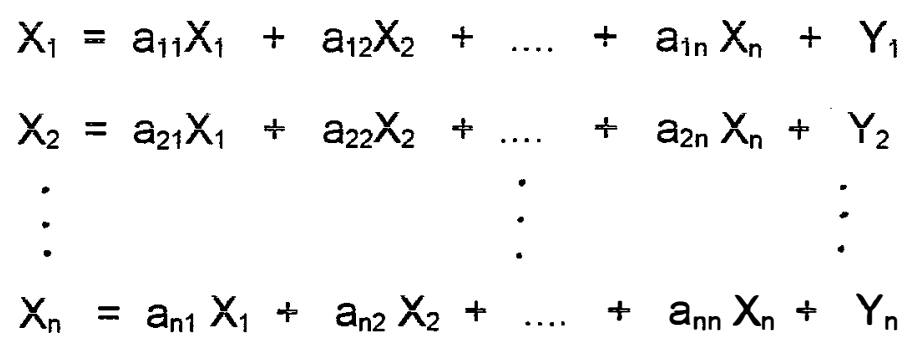

O conjunto de coeficientes técnicos $a_{i j}$ constitui a matriz $A$, de modo que os $a_{i j}$ descrevem a estrutura tecnológica utilizada em todos os setores da economia. Os coeficientes técnicos expressam não só a tecnologia adotada nas diferentes indústrias, como também os preços relativos das mercadorias produzidas nessas indústrias. Cada coeficiente $a_{\mathrm{ij}}$ mostra a quantia que deve ser gasta na mercadoria $i$, utilizada como insumo na produção de uma quantidade da mercadoria $j$ suficiente para se obter uma unidade monetária de receita, ou seja, representa quanto o setor $j$ compra do setor $i$, se o setor $j$ produzir um total $X_{j}$.

\subsubsection{Representação matricial do modelo}

Baseado em Miller e Blair (1985), Leontief (1951) e Guilhoto (1992), pode=se afirmar que os fluxos entre os setores na economia são determinados por fatores de ordem econômica e tecnológica e suas descrições são realizadas por intermédio de equações simultâneas em termos de matrizes:

$$
X=A X+Y
$$

onde $X$ é o vetor com o vaior da produção total por setor, cuja dimensão é $n \times 1$; $Y$ é o vetor com o valor da demanda final por setor e tem dimensão $n \times 1$. A matriz $A$ é constituída de coeficientes técnicos de produção, sua dimensão é $n \times n$. Para o modelo 
tradicional de Leontief, o vetor demanda final é exógeno, desta forma o vetor produção total é determinado apenas pelo vetor demanda final, em termos de matrizes temos:

$$
X=B Y
$$

onde $B$ contém a matriz inversa de Leontief e tem dimensão $n \times n$ :

$$
B=(I-A)^{-1}
$$

Os coeficientes da matriz inversa de Leontief captam os efeitos diretos e indiretos de modificações exógenas da demanda final sobre o nivel de produção dos setores, sendo que cada coeficiente desta matriz revela o aumento de produção do setor (apresentado na linha) necessário para atender a um aumento de uma unidade monetária na demanda final do setor (apresentado na coluna).

Partindo-se da expressão (7), é possivel determinar o impacto que as mudanças ocorridas nos componentes da demanda final teriam sobre a produção total por setor, sendo esse procedimento dado por:

$$
X=(I-A)^{-1} \cdot Y
$$

o vetor $Y$ engloba o consumo das familias $\left(Y_{f}\right)$, as exportações $\left(Y_{x}\right)$, os gastos do governo $\left(Y_{g}\right)$ e os investimentos $\left(Y_{k}\right)$.

O termo $(I-A)^{-1}$ é a matriz dos multiplicadores de Leontief ou dos coeficientes de efeitos diretos e indiretos e quando pré-multiplica o vetor de demanda final, produz $X$, somatório da produção total (e não apenas do valor agregado) de todas as atividades da economia, ou ainda o efeito final sobre a economia provocado pelo aumento na produção de bens finais. Esse efeito é dividido entre o efeito direto (os próprios bens finais) e os efeitos indiretos (produção de insumos necessária à produção direta), e assim por diante. Os coeficientes da matriz dos coeficientes técnicos indicam a participação de cada atividade na produção das demais atividades. 
O modeio de insumo-produto relaciona, portanto, a demanda final com a produção das " $n$ " atividades da economia.

\subsection{3 - Multiplicadores}

A partir da equação (7), pode-se obter os valores dos multiplicadores de produção que correspondem a soma das colunas da matriz de coeficientes de efeitos diretos e indiretos, (matriz B), ou seja, da matriz inversa de Leontief.

Tais multiplicadores fornecem informações a respeito do aumento, em unidades, do produto total, causado pelo aumento de uma unidade na demanda final do produto de um setor, dada as ligações intersetoriais na economia.

Partindo-se também da equação (7) pode-se obter os multiplicadores de produtos importados, obtidos a partir da soma dos elementos da matriz resultante da multiplicação da matriz inversa de Leontief pela matriz de coeficientes técnicos.

Portanto, tem=se que

$$
M S=1 . B
$$

onde $1=\left[\begin{array}{ll}1 & \ldots \\ 1\end{array}\right]$ com dimensão $1 \times \mathrm{n}$; B é a matriz inversa de Leontief e MS são os multiplicadores setoriais. Pode-se definir os multiplicadores de produtos importados (MSm) a partir de:

$$
M S m=1 . C m . B
$$

onde $\mathrm{Cm}$ é uma matriz constituída de coeficientes técnicos de importações, por país, e sua dimensão é $n \times n$.

Esses multiplicadores visam determinar o impacto de variações da demanda final sobre o nivel de produção total e de importação. Dependendo do comportamento 
da demanda final, obtêm-se diferentes resultados em termos das variáveis descritas (MicGilvray, 1977), resultados que não são captados quando se analisam apenas a estrutura produtiva.

Ainda, os multiplicadores são utilizados para determinar o impacto de diferentes políticas governamentais sobre os salários e distribuição de renda.

\section{3 Índices de ligação para frente e para trás}

A partir do modelo exposto no ítem 4.2, consegue-se determinar quais seriam os setores que teriam o maior poder de encadeamento dentro da economia. Acredita=se que "o processo de transformação econômica é frequentemente estimulado por um número relativamente pequeno de setores, mesmo se a economia como um todo acabe sofrendo mudanças" (Guilhoto, et al., 1994).

Seguindo=se o conceito de setores-chave de Rasmussen (1956) e Hirschman (1958), pode-se definir os indices de ligações para trás e para frente conforme segue:

Índice de ligações para trás - indice que mostra o quanto um setor demanda dos outros setores, ou seja, até que ponto um setor demanda insumos da economia, em comparação com os demais, sendo que valores maiores do que 1 indicam um setor altamente dependente do restante da economia.

Índice de Ligações para frente - indice que revela o quanto um setor é demandado pelos outros setores, ou seja, até que ponto um dado setor, em comparação com os demais setores, tem seus insumos demandados pela economia, sendo que valores maiores do que 1 indicam um setor cuja produção é amplamente utilizada pelos demais. 
Os setores que apresentam vaiores desses indices maiores que 1 são considerados setores-chave para o crescimento da economia, pois valores maiores que 1 indicam setores acima da média.

A partir da equação (7), define-se $b_{i j}$ como um elemento da matriz inversa de Leontief $B ; B^{*}$ como a média de todos os elementos de $B$; e $B_{{ }_{j j}}$ e $B_{i^{*}}$ como as somas de uma coluna e de uma linha tipicas de $B$, respectivamente. Os indices serão:

. Índices de ligações para trás:

$U_{j}=\left[B_{x_{j}} / n\right] / B^{*}$

. Índices de ligações para frente:

$$
U_{i}=\left[B_{i} \star n\right] / B^{*}
$$

Os indices de Rasmussen (1956) podem ser complementados com indices de dispersão segundo Bulmer=Thomas, (1982), definidos da seguinte maneira:

Dispersão dos índices de ligações para trás: indice que informa como um impacto setorial se distribui para os outros setores; valor baixo de dispersão significa que o impacto de uma variação da produção num dado setor estimula os demais, de maneira uniforme; valor elevado de dispersão significa que o estimulo se concentra em poucos setores. Tem=se:

$$
V_{j}=\frac{\sqrt{\frac{\sum_{i=1}^{n}\left(b_{i j}-\frac{B_{*_{j}}}{n}\right)^{2}}{(n-1)}}}{\frac{B_{*_{j}}}{n}}
$$


Dispersão dos índices de ligações para frente: este índice significa o quanto um dado setor é demandado peios outros: valor baixo de dispersão significa que é demandado de maneira uniforme; valor elevado de dispersão significa que a demanda por esse setor se concentra em poucos setores. Tem-se:

$$
F_{i}=\frac{\sqrt{\frac{\sum_{i=n}^{n}\left(b_{i j}=\frac{B_{i *}}{n}\right)^{2}}{(n-1)}}}{\frac{B_{i^{*}}}{n}}
$$

Há extensa literatura sobre o conceito de setores=chave (MicGilvray, 1977; Hewings, 1982). O conceito de Rasmussen e Hirschman vem recebendo grande volume de aplicação e comentários críticos. Uma das críticas sobre estes índices é a de que eles não consideram os diferentes niveis de produção em cada setor da economia (Guilhoto, et. al., 1994).

\section{4 Índice puro de ligações interindustriais}

O indice puro de ligações interindustriais é um procedimento complementar para separar os impactos de um determinado setor dos demais setores da economia, ou de uma determinada região do restante da economia, ou ainda de um determinado país de um bloco econômico no qual esteja inserido (Guilhoto, Hewings, Sonis - 1996 e Guilhoto, Hewings, Sonis = 1997). Esse índice é um aperfeiçoamento do enfoque de Cella-Clements, desenvolvido por Cella e aplicado por Clements e Rossi para o Brasil (Cella, 1984; Clements e Rossi, 1991 e 1992, Guilhoto et al., 1994). 
A idéia básica é isolar um determinado setor $j$ do restante da economia, de forma a definir o efeito das ligações totais desse setor, ou seja, a diferença entre a produção total da economia e a produção na economia se o setor $j$ não comprasse insumos do resto da economia e não vendesse sua produção para o resto da economia. Essa situação equivale ao oposto da substituição de importações, ou ainda, ao desaparecimento de todo um setor industrial.

Para isolar o setor $j$ do resto da economia considera-se um sistema de insumoproduto de dois setores, representado pela matriz de coeficientes diretos de Leontief (A) (Guilhoto, Hewings, Sonis, 1997) da seguinte forma:

$$
A=\left[\begin{array}{ll}
A_{i j} & A_{j r} \\
A_{r j} & A_{r r}
\end{array}\right]
$$

onde $A_{\mathrm{jj}}$ e $A_{r r}$ são matrizes quadradas de coeficientes diretos, dentro dos primeiro e segundo setores e $A_{j r}$ e $A_{r j}$ são matrizes retangulares mostrando os insumos diretos comprados pelo setor $r$ do setor $j$.

De (15), pode-se gerar a seguinte expressão:

$B=(i-A)^{-1}=\left[\begin{array}{cc}B_{i j} & B_{j r} \\ B_{r j} & B_{r r}\end{array}\right]=\left[\begin{array}{cc}\Delta_{j j} & 0 \\ 0 & \Delta_{r r}\end{array}\right]\left[\begin{array}{cc}\Delta_{j} & 0 \\ 0 & \Delta_{r}\end{array}\right]\left[\begin{array}{ll}1 & A_{j r} \Delta_{r} \\ A_{r j} \Delta_{j} & I\end{array}\right]$

onde:

$$
\begin{aligned}
& \Delta_{j}=\left(I-A_{i j}\right)^{-1} \\
& \Delta_{r}=\left(I-A_{r r}\right)^{-1}
\end{aligned}
$$




$$
\begin{aligned}
& \Delta_{\mathrm{jj}}=\left(I-\Delta_{\mathrm{j}} A_{\mathrm{j} r} \Delta_{\mathrm{r}} \mathrm{A}_{\mathrm{rj}}\right)^{-1} \\
& \Delta_{r r}=\left(I-\Delta_{\mathrm{r}} A_{\mathrm{rj}} \Delta_{\mathrm{j}} A_{\mathrm{jr}}\right)^{-1}
\end{aligned}
$$

Da fórmula de Leontief:

$$
X=(I-A)^{-1} Y
$$

e utilizando-se as informações contidas nas equações (16) a (20), pode-se derivar um conjunto de indices que pode ser utilizado: a) para classificar os setores quanto à sua importância na economia; b) para verificar como o processo de produção ocorre na economia.

Das equações (16) a (20) obtém-se:

$$
\left[\begin{array}{l}
X_{i} \\
X_{r}
\end{array}\right]=\left[\begin{array}{cc}
\Delta_{i j} & 0 \\
0 & \Delta_{r r}
\end{array}\right]\left[\begin{array}{ll}
\Delta_{j} & 0 \\
0 & \Delta_{r}
\end{array}\right]\left[\begin{array}{ll}
1 & A_{j r} \Delta_{r} \\
A_{r j} \Delta_{j} & l
\end{array}\right]\left[\begin{array}{l}
Y_{j} \\
Y_{r}
\end{array}\right]
$$

que pode ser escrita como:

$$
\left[\begin{array}{l}
X_{j} \\
X_{r}
\end{array}\right]=\left[\begin{array}{cc}
\Delta_{j j} & 0 \\
0 & \Delta_{\pi}
\end{array}\right]\left[\begin{array}{ll}
\Delta_{j} & 0 \\
0 & \Delta_{r}
\end{array}\right]\left[\begin{array}{l}
Y_{j}+A_{j r} \Delta_{r} Y_{r} \\
A_{r j} \Delta_{j} Y_{j}+Y_{r}
\end{array}\right]
$$

onde $A_{j r} \Delta_{r} Y_{r}$ é o impacto direto da demanda final do resto da economia sobre o setor $j$, ou seja, indica o nivel de exportação do setor $j$ que é necessário para satisfazer as necessidades de produção do resto da economia para o nível da demanda final dado por $Y_{r} ;$ e $A_{r j} \Delta_{j} Y_{j}$ é o impacto direto da demanda final do setor $j$ sobre o resto da economia, ou seja, indica o nivel das exportações do resto da economia que é 
necessário para satisfazer as necessidades de produção do setor $j$ para o nivel de demanda final dado por $Y_{j}$.

Retomando à equação (23):

$$
\left[\begin{array}{l}
X_{j} \\
X_{r}
\end{array}\right]=\left[\begin{array}{cc}
\Delta_{j j} & 0 \\
0 & \Delta_{r}
\end{array}\right]\left[\begin{array}{c}
\Delta_{j} Y_{j}+\Delta_{j} A_{j r} \Delta_{r} Y_{r} \\
\Delta_{r} A_{r j} \Delta_{j} Y_{j}+\Delta_{r} Y_{r}
\end{array}\right]
$$

Tem-se, então, as definições de Índice Puro de Ligação para Trás (PBL) e Índice Puro de Ligações para Frente (PFL), isto é,

$$
\begin{aligned}
& P B L=\Delta_{r} A_{r j} \Delta_{j} Y_{j} \\
& P F L=\Delta_{j} A_{j r} \Delta_{r} Y_{r}
\end{aligned}
$$

O İndice puro de ligação para trás $(\mathrm{PBL})$ dá o impacto na economia do valor da produção total do setor $j,\left(\Delta_{\mathrm{j}} \mathrm{Y}_{\mathrm{j}}\right)$; isto é, o impacto que é dissociado da demanda de insumos que o setor $j$ realiza do próprio setor $j$, e dos retornos da economia para $o$ setor $j$ e vice-versa.

O Índice puro de ligação para frente (PFL) fornece o impacto puro no setor $j$ da produção total no resto da economia, $\left(\Delta_{r} Y_{r}\right)$.

A soma do índice puro de ligações para trás $(P B L)$ com o índice puro de ligações para frente (PFL) resulta no índice puro do total das ligações (PTL) de cada setor na 
economia, uma vez que tais índices são expressos em valores correntes. Assim, temse que: $P T L=P B L+P F L$.

Partindo-se novamente da equação (24):

$$
\left[\begin{array}{l}
X_{j} \\
X_{r}
\end{array}\right]=\left[\begin{array}{c}
\Delta_{i j} \Delta_{j} Y_{j}+\Delta_{i j} \Delta_{j} A_{j r} \Delta_{r} Y_{r} \\
\Delta_{r r} \Delta_{r} A_{r j} \Delta_{j} Y_{j}+\Delta_{r} \Delta_{r} Y_{r}
\end{array}\right]=\left[\begin{array}{l}
X_{j}^{j}+X_{j}^{r} \\
X_{r}^{j}+X_{r}^{r}
\end{array}\right]
$$

o nivel da produção total no setor $j$ pode, então, ser dividido em dois componentes: $X_{j}^{j}=\Delta_{i j} \Delta_{j} Y_{j}$ e $X_{j}^{r}=\Delta_{j j} \Delta_{j} A_{j i} \Delta_{r} Y_{r}$ onde o primeiro componente, $X_{j}^{j}$, indica o nivel de produção total no setor $j$ que é devido ao nivel da demanda final no setor $j$, e o segundo componente, $X_{j}^{r}$, será o nivel do total da produção no setor $j$ que é devido ao nivel da demanda final do resto da economia. Da mesma forma, o nivel total de produção no resto da economia pode também ser dividido em dois componentes: $X_{r}^{j}=\Delta_{r r} \Delta_{r} A_{r j} \Delta_{j} Y_{j}$ e $X_{r}^{r}=\Delta_{r r} \Delta_{r} Y_{r}$ onde o primeiro componente $X_{r}^{j}$, é o nível de produção total no resto da economia que é devido ao nivel de demanda final no setor $j$, e o segundo componente, $X_{r}^{r}$, dará o nivel de produção total do resto da economia que é devido ao nivel de demanda final do resto da economia.

\subsection{Campo de influência}

Uma outra perspectiva utilizada por Sonis \& Hewings (1989) e utilizada por Hewings, Fonseca, Guilhoto e Sonis (1989) numa aplicação para o Brasil que contempla a definição utilizada em (16) é o enfoque do Campo de Influência. Esse conceito de Campo de Influência descreve como se distribuem as mudanças dos coeficientes diretos no sistema econômico como um todo, permitindo desta forma determinar quais as relações entre os setores que seriam mais importantes dentro do processo produtivo. 
O enfoque que se atribui ao campo de influência representa uma análise complementar ao de indice de ligações. Esse conceito permite identificar quais os coeficientes que causariam maior impacto no sistema como um todo, caso fossem alterados. São descritas as distribuições das mudanças dos coeficientes diretos no sistema econômico como um todo, permitindo determinar quais as relações entre os setores que seriam mais importantes dentro do processo produtivo. Os principais elos de ligação dentro da economia vão se encontrar nos setores que apresentam maiores indices de ligações, tanto para frente como para trás (Sonis, Hewings, 1994, Guilhoto et al., 1994).

Considerando a matriz de coeficientes diretos $A=\left[a_{i j}\right]$ e definindo-se $E=\left[e_{i j}\right]$ como a matriz de variações incrementais nos coeficientes diretos de insumo, as correspondentes matrizes inversas de Leontief são dadas por:

$$
B=[(I-A)]^{-1}=\left[b_{i j}\right]
$$

e por

$$
B(\epsilon)=[1-A-\epsilon]^{-1}=\left[b_{i j}(\epsilon)\right]
$$

De acordo com Sonis, Hewings (1994), com uma variação pequena que ocorre em apenas um coeficiente tem-se:

$$
\epsilon_{i j}=\left[\begin{array}{cc}
\in & i=i_{1}, j=j_{1} \\
0 & i \neq i_{1}, \text { ou } j \neq j_{1}
\end{array}\right.
$$

e o campo de influência desta variação pode ser aproximado pela expressão: 


$$
F\left(\epsilon_{i j}\right)=\frac{\left[B\left(\epsilon_{i j}\right)-B\right]}{\epsilon_{i j}}
$$

onde $F\left(\epsilon_{i j}\right)$ é a matriz $(n \times n)$ do campo de influência do coeficiente $a_{i j}$.

Para a determinação dos coeficientes que apresentam maior campo de influência associa-se a cada matriz $F\left(\epsilon_{\mathrm{ij}}\right)$ um valor dado por:

$$
S_{i j}=\sum_{k=1}^{n} \sum_{l=1}^{n}\left[\mathbf{f} k l\left(\epsilon_{i j}\right)\right]^{2}
$$

Os coeficientes diretos que possuirem os maiores valores de $S_{i j}$ serão aqueles com maior campo de influência dentro da economia como um todo.

Como observa Guilhoto et al. (1994), a abordagem de Rasmussen-Hirschman e a de Campo de Influência levam em conta o comportamento da estrutura interna da economia, independente do valor da produção total, enquanto o Índice Puro analisa a estrutura produtiva levando em consideração os níveis de produção setorial. Os enfoques de Rasmussen-Hirschman e de Campo de Influência mostram o potencial dos impactos de mudanças em um setor especifico, enquanto 0 índice puro avalia 0 impacto realizado através das considerações do volume de atividade.

\subsection{Apresentação das fontes e tratamento dos dados}

Para a realização deste trabalho utiliza-se duas fontes de dados. As informações provenientes das Matrizes de Insumo-Produto do IBGE elaboradas para o Brasil com base em dados censitários, que fornecem as estimativas quanto às relações intersetoriais entre as quais se destacam os coeficientes de efeitos diretos e indiretos utilizados nos cálculos dos requisitos diretos e indiretos de produção que constituíramse na primeira fonte. 
As matrizes fornecem também os dados de exportações e importações totais (ver IBGE, 1990-1994). A matriz de insumo-produto do Brasil constitui a fonte básica dos dados, embora não exclusiva.

A segunda fonte, utilizada para obter os dados quanto às exportações e importações por origem e destino, abrange o conjunto de informações da Secretaria do Comércio Exterior do Ministério da Indústria, Comércio e Turismo (SECEX-MICT) de 1990 a 1996.

Foram extraídos daí os dados quanto às exportações brasileiras, por produto, para os paises que formam o MERCOSUL, ou seja, Argentina, Paraguai e Uruguai, incluindo o Chile, a Bolívia e o "setor" Resto do Mundo e, quanto às importações brasileiras dos paises do MERCOSUL, ou seja, Argentina, Paraguai e Uruguai, adicionando o Chile, a Bolívia e o "setor" Resto do Mundo.

A classificação do SECEX-MICT segue a classificação da NBM que difere da classificação de atividades "nível 100" das matrizes do IBGE utilizadas neste trabalho. A compatibilização é possivel pelas instruções que constam na matriz de insumoproduto do próprio IBGE, para o ano de 1985. Superada esta dificuldade, apresenta-se no Apêndice $\mathrm{C}$ a compatibilização realizada.

O número de setores foi definido em 21 (Tabela 4.1), sendo que para a determinação deste número levou-se em consideração: a) a disponibilidade dos dados; e, b) a importância dos setores para a economia brasileira como um todo. (ver Sonis, Guilhoto, Hewings e Martins, 1994).

Ainda, para a agregação dos setores e produtos foi utilizada as tabelas básicas do IBGE (matriz de produção - Brasil 1990-1994 e matriz de insumo das atividades e demanda final - Brasil 1990-1994) com base na nomenclatura de Miller e Blair (1985). Procedeu-se assim, as agregações resultando em dụas matrizes denominadas de matriz de produção e matriz de uso para o período considerado no presente trabalho. 
A agregação dos setores foi resultado de duas etapas a partir das tabelas básicas do IBGE. Na primeira etapa foi realizada a agregação nas tabelas básicas das linhas e, na Segunda etapa das colunas, obtendo-se a agregação de setores e produtos.

A metodologia utilizada para a agregação dos setores e produtos para a obtenção dos 21 setores é apresentada também no Apêndice C. Além disso, a estrutura das matrizes de insumo-produto utilizada neste trabalho é apresentada na figura 4.1 .

Feito isso, procede-se ao tratamento das exportações e importações brasileiras, por etapas. A primeira etapa consiste na expansão do vetor coluna exportações brasileiras da matriz de insumo-produto do Brasil, 1990-1994, em seis vetores, a saber: vetor contendo as exportações brasileiras para a Argentina, Paraguai, Uruguai, Chile, Bolivia e Resto do Mundo.

Os dados que se apura para cada vetor seguem os seguintes passos: primeiro, a partir das tabelas que mostram as exportações brasileiras expressas em preços/ FOB, para o MERCOSUL, Chile, Bolivia e Resto do Mundo, obteve-se as participações das exportações de cada pais nas exportações totais para o periodo analisado.

Essas participações foram geradas dividindo-se o valor das exportações, por setor, de cada vetor, pelo valor obtido a partir do total do vetor das exportações. Segundo, os valores monetários das exportações brasileiras para o ano de 1990 a preço básico foi gerado através da multiplicação dos indices contidos nas tabelas de participações, por setor, pelo respectivo vetor de exportações totais, também por setor. O mesmo procedimento foi utilizado para os anos de 1991, 1992, 1993 e 1994.

A segunda etapa apresenta o tratamento das importações brasileiras onde a matriz que contém as importações é expandida em seis matrizes, a saber: matriz de produtos importados da Argentina, Paraguai, Uruguai, Chile, Bolivia e Resto do Mundo. 
A metodologia usada para a obtenção dos dados para cada matriz segue os seguintes passos: a partir das tabelas que mostram as importações brasileiras do MERCOSUL, Chile, Bolivia e Resto do Mundo, em US\$ milhões/FOB, obteve-se a participação de cada país, por setor, sobre o total das importações brasileiras, para o período analisado, sendo que essas participações foram apuradas pela divisão do valor das importações de cada país, por setor, pelo valor total das importações, por setor.

Os valores monetários das importações brasileiras para o ano de 1990, a preços CIF, foram apurados através da multiplicação das participações dos países, por setores, na importação total apresentada na matriz de produtos importados do IBGE; partindo-se da matriz de produtos importados do IBGE, procede-se ao cálculo da distribuição setorial da demanda total.

Este cálculo foi feito pela divisão do valor referente ao que foi aplicado a cada setor pelo total das importações; e, por último, as seis matrizes de importações utilizadas neste trabalho foram obtidas pela multiplicação dos valores monetários referentes à participação de cada país no total das importações pela distribuição setorial na demanda total.

Todas as tabelas utilizadas para o cálculo das participações e distribuições setoriais encontram-se no Apêndice $D$. 
Tabela 4.1 - Setores do Modelo

\begin{tabular}{cc}
\hline Setor & Nome \\
\hline 1 & Agropecuária \\
2 & Mineração \\
3 & Minerais não Metálicos \\
4 & Metalurgia \\
5 & Mecânica e Material Elétrico \\
6 & Material de Transporte \\
7 & Madeira e Mobiliário \\
8 & Papel e Papelão \\
9 & Borracha \\
10 & Indústria Química \\
11 & Indústria Farmacêutica \\
12 & Plásticos \\
13 & Indústria Têxtil \\
14 & Vestuário \\
15 & Calçados e Couros \\
16 & Produtos Alimentares \\
17 & Diversos \\
18 & Construção Civil \\
19 & Serviços Industriais de Utilidade Pública \\
20 & Transporte e Margem de Comércio \\
21 & Serviços \\
\hline
\end{tabular}




\begin{tabular}{|l|c|c|}
\cline { 2 - 3 } \multicolumn{1}{c|}{} & $\begin{array}{l}\text { Indústrias Nacionais } \\
\text { (Produção Corrente) }\end{array}$ & Demanda Final \\
\hline Indústrias Nacionais & $\mathrm{A} 1$ & $\mathrm{D} 1$ \\
\hline Importações da Argentina & $\mathrm{A} 2$ & $\mathrm{D} 2$ \\
\hline Importações do Paraguai & $\mathrm{A} 3$ & $\mathrm{D} 3$ \\
\hline Importações do Uruguai & $\mathrm{A} 4$ & $\mathrm{D} 4$ \\
\hline Importações do Chile & $\mathrm{A} 5$ & $\mathrm{D} 5$ \\
\hline Importações da Bolivia & $\mathrm{A} 6$ & $\mathrm{D} 6$ \\
\hline $\begin{array}{l}\text { Importações do Resto do } \\
\text { Mundo }\end{array}$ & $\mathrm{A} 7$ & $\mathrm{D} 7$ \\
\hline Impostos Indiretos Liquidos & $\mathrm{A} 8$ & $\mathrm{D} 8$ \\
\hline Valor Adicionado & A9 & D9 \\
\hline
\end{tabular}

Figura 4.1 - Estrutura das Matrizes de Insumo - Produto Utilizada no Modelo 


\section{RESULTADOS E DISCUSSŌES}

\subsection{Mudanças estruturais}

\subsubsection{Estrutura produtiva}

A economia brasileira teve seu crescimento econômico até a década de 80 baseado na exportação de produtos primários e no modelo de substituição de importações (Baer, 1996). A partir de 1990 busca-se novos caminhos de desenvolvimento, entre eles, a integração regional no âmbito internacional. A análise da estrutura produtiva e dos setores-chave permitirá compreender como se encontrava a economia brasileira antes da criação do MERCOSUL e após a assinatura do Tratado de Assunção.

As Tabelas 5.1 e 5.2 apresentam a distribuição do valor adicionado e a distribuição percentual da produção total da economia brasileira por setor, no periodo de 1990-1994 obtida a partir da agregação realizada neste trabalho. Pode-se notar que a estrutura industrial permaneceu mais ou menos constante no periodo analisado.

Através da distribuição da produção entre os 21 setores, nota-se que a produção brasileira está concentrada nos setores: primário e nas indústrias a ele relacionadas diretamente (1 - Agropecuária e 16 - Produtos Alimentares); no setor industrial (10 - 
Química, 4 - Metalurgia e 5 - Mecânica e Material Elétrico), e no setor terciário (19 Construção Civil, 20 - Transporte e M. Comércio e 21 - serviços).

Esta participação mostra que houve, no período 1990 -1994, uma predominância do setor terciário (setores 20 - Transporte e M. Comércio e 21 - Serviços), os quais responderam por $44,26 \%, 45,46 \%, 46,96 \%, 48,84 \%$ e $43,96 \%$ da produção nos anos de 1990, 1991, 1992, 1993 e 1994 respectivamente. O setor agropecuário (setor 1) respondeu por $6,38 \%, 6,50 \%, 6,26 \%, 5,92 \%$ e $7,70 \%$ da produção no período de 1990 1994, respectivamente. A análise da estrutura da produção da economia brasileira mostra, portanto, que a produção se encontra mais bem distribuída, onde a estrutura industrial permaneceu de certa forma constante no período 1990-94. O setor agrícola aumentou sua participação na produção passando de 6,38\% em 1990 para 7,70\% em 1994. Cabe ressaltar a crescente importância do setor de serviços dentro da economia, seguindo uma tendência deste setor dentro de economias mais desenvolvidas. 
Tabela 5.1 - Valor Adicionado (Distribuição Percentual) - 1990-1994

\begin{tabular}{|c|c|c|c|c|c|}
\hline Setores & 1990 & 1991 & 1992 & 1993 & 1994 \\
\hline 1 Agropeauzia & 6,92 & 6,90 & 6,23 & 5,78 & 8,63 \\
\hline 2 Mineração & 1,29 & 1,30 & 1,15 & 0,72 & 0,73 \\
\hline 3 Minerais não Metálicos & 1,13 & 1,22 & 1,05 & 0,94 & 1,13 \\
\hline 4 Metalurgia & 2,53 & 2,66 & 2,46 & 2,30 & $2, \infty 3$ \\
\hline 5 Mecânica e Material Elétrico & 3,79 & 3,31 & 3,34 & 3,39 & 3,79 \\
\hline 6 Material de Transporte & 1,51 & 1,45 & 1,40 & 1,51 & 1,81 \\
\hline 7 Madeira e Mobiliário & 0,85 & 0,82 & 0,63 & 0,71 & 0,83 \\
\hline 8 Papel e Papeläo & 1,03 & 1,30 & 0,94 & 0,70 & 0,79 \\
\hline 9 Borracha & 0,36 & 0,35 & 0,35 & 0,33 & 0,35 \\
\hline 10 Indústria Cuimica & 4,20 & 3,98 & 4,60 & 5,70 & 5,15 \\
\hline 11 Indústria Farmacêtutica & $0, \varpi 3$ & 0,49 & 0,68 & 0,75 & 0,74 \\
\hline 12 Plísticas & 0,6 & 0,59 & 0,50 & 0,51 & 0,49 \\
\hline 13 Indústria Téxtil & 1,34 & 1,07 & 0,88 & 0,84 & 0,82 \\
\hline 14 Vestuário & 0,92 & 0,69 & 0,59 & 0,53 & 0,57 \\
\hline 15 Caffeados e Couros & 0,38 & 0,36 & 0,41 & 0,39 & 0,35 \\
\hline 16 Produtos Alimeitares & 2,82 & 3,22 & 3,30 & 3,14 & 3,46 \\
\hline 17 Diversos & 0,60 & 0,61 & 0,56 & 0,51 & 0,56 \\
\hline 18 Serviços Industriais de U.P. & 2,28 & 2,27 & 2,45 & 2,38 & 2,66 \\
\hline 19 Construção Civil & 6,64 & 6,31 & 6,13 & 6,31 & 8,08 \\
\hline 20 Transpote e M. Comércio & 12,74 & 12,04 & 10,43 & 9,91 & 11,35 \\
\hline 21 Serviços & 47,36 & 49,06 & 51,91 & 52,66 & 45,09 \\
\hline Total & 100 & 100 & 100 & 100 & 100 \\
\hline
\end{tabular}

Fonte: IBGE - Matriz de Relaçōes Intersetoriajs - Brasil. 1990/94. 
Tabela 5.2 - Estrutura Produtiva (Distribuição Percentual)

Brasil - 1990-1994

\begin{tabular}{|c|c|c|c|c|c|c|}
\hline & Setores & 1990 & 1991 & 1992 & 1993 & 1994 \\
\hline 1 & Agropecuária & 6,38 & 6,50 & 6,26 & 5,92 & 7,70 \\
\hline 2 & Mineração & 1,36 & 1,32 & 1,27 & 0,99 & 0,97 \\
\hline 3 & Minerais não Metálicos & 1,51 & 1,52 & 1,39 & 1,28 & 1,38 \\
\hline 4 & Metalurgia & 4,88 & 4,80 & 4,77 & 4,43 & 4,74 \\
\hline 5 & Mecânica e Material Elétrico & 4,84 & 4,17 & 4,01 & 3,95 & 4,31 \\
\hline 6 & Material de Transporte & 2,80 & 2,55 & 2,49 & 2,67 & 3,01 \\
\hline 7 & Madeira e Mobiliário & 1,18 & 1,04 & 0,91 & 0,97 & 1,07 \\
\hline 8 & Papel e Papelāo & 1,81 & 1,98 & 1,72 & 1,50 & 1,57 \\
\hline 9 & Borracha & 0,60 & 0,59 & 0,59 & 0,57 & 0,60 \\
\hline 10 & Indústria Quimica & 6,93 & 6,83 & 7,09 & 7,07 & 6,84 \\
\hline 11 & Indủstria Farmacêutica & 0,85 & 0,78 & 0,88 & 0,91 & 0,88 \\
\hline 12 & Plásticos & 0,82 & 0,76 & 0,68 & 0,67 & 0,66 \\
\hline 13 & Indústria Têxtil & 2,16 & 1,95 & 1,70 & 1,56 & 1,57 \\
\hline 14 & Vestuário & 1,20 & 0,97 & 0,84 & 0,78 & 0,79 \\
\hline 15 & Calçados e Couros & 0,69 & 0,62 & 0,60 & 0,60 & 0,54 \\
\hline 16 & Produtos Alimentares & 6,93 & 7,44 & 7,37 & 7,10 & 7,94 \\
\hline 17 & Diversos & 0,66 & 0,66 & 0,63 & 0,63 & 0,65 \\
\hline 18 & Serviços Industriais de U.P. & 2,50 & 2,87 & 3,03 & 2,84 & 2,89 \\
\hline 19 & Construçāo Civil & 7,64 & 7,18 & 6,82 & 6,93 & 7,94 \\
\hline 20 & Transporte e M. Comércio & 11,52 & 10,91 & 10,45 & 10,60 & 10,87 \\
\hline 21 & Serviços & 32,74 & 34,55 & 36,51 & 38,04 & 33,09 \\
\hline & Total & 100 & 100 & 100 & 100 & 100 \\
\hline
\end{tabular}

Fonte: IBGE - Matriz de Relaçōes Intersetoriais - Brasil.

$1990 / 94$. 


\subsubsection{Estrutura da demanda final}

As tabelas 5.3 e 5.4 mostram a participação da demanda final na produção total (\%) e a participação das exportações totais na produção total (\%), no período de 1990 1994.

A participação da demanda na produção total setorial mostra que a agricultura brasileira apresenta de modo geral baixa participação da demanda final na produção total, o que indica um alto grau de interligação setorial da agricultura na economia, pois uma participação menor da produção total na demanda final implica uma utilização maior dos recursos dentro do processo produtivo.

Os setores 18 a 21 , que representam os serviços, mostram-se importante dentro da estrutura de consumo final e da economia, antes e depois da criação do MERCOSUL. Os serviços ficaram à frente à custa de todos os outros setores, o que pode ter sido causado, em grande parte, pela inflação do período.

A Tabela 5.4 mostra a participação das exportações brasileiras no produto total de cada setor. Essas proporções indicam claramente que houve uma pequena abertura da economia brasileira no periodo analisado, através do aumento progressivo nos coeficientes de exportações em todos os setores apresentados neste trabalho, principalmente para os setores 6 - Material de Transporte; 9 - Borracha; 5 - Mecânica e Material Elétrico, no período de 1990-1992. A partir de 1992, pode-se incluir o setor 8 - Papel e Papelão.

O crescimento das exportações brasileiras para o MERCOSUL resultou no acúmulo de superávits com os demais países-membros. Com a Argentina, a balança comercial, que era deficitária em 1990 e 1991, alcançou superávits da ordem de US\$ 1.030 milhões em 1993, declinando para US\$ 523 milhões em 1994. 
Além do programa de desgravação tarifária iniciado em 1991, dois outros fatores tiveram papel importante na obtenção desses resultados. A economia brasileira passava por um período recessivo no início dos anos 90, enquanto a economia argentina estava em pieno ciclo de expansão. A taxa média anual de crescimento do PIB real entre 1990 e 1993 foi de 2,45\% no Brasil e de 8,03\% na Argentina (Pereira, 1996). A adoção de uma paridade fixa entre o peso argentino e o dólar, associada ao plano de estabilização, refletiu numa expressiva valorização da moeda argentina em relação à moeda brasileira.

Tabeia 5.3 - Participação da Demanda Finai na Produção Total (\%) - 1990-1994

\begin{tabular}{lccccc}
\hline \multicolumn{1}{c}{ Setores } & 1990 & 1991 & 1992 & 1993 & 1994 \\
\hline 1 Agropecuária & 31,89 & 30,03 & 29,63 & 26,07 & 29,82 \\
2 Mineração & 22,22 & 28,13 & 27,85 & 25,02 & 24,23 \\
3 Minerais não Metálicos & 7,40 & 8,82 & 8,77 & 8,84 & 7,47 \\
4 Metalurgia & 14,46 & 18,72 & 20,00 & 18,76 & 17,58 \\
$\mathbf{5}$ Mecânica e Material Elétrico & 49,31 & 50,48 & 47,43 & 51,70 & 58,44 \\
6 Material de Transporte & 53,31 & 56,93 & 55,73 & 60,44 & 61,59 \\
7 Madeira e Mobiliário & 52,97 & 52,97 & 54,22 & 56,93 & 55,28 \\
8 Papei e Papelão & 24,45 & 23,48 & 23,72 & 26,05 & 27,23 \\
9 Borracha & 7,04 & 9,23 & 9,74 & 11,70 & 12,71 \\
10 indústria Química & 23,29 & 26,73 & 27,69 & 32,17 & 28,67 \\
11 Indústria Farmacêutica & 86,39 & 88,44 & 85,30 & 87,59 & 92,41 \\
12 Plásticos & 7,73 & 9,73 & 9,04 & 10,72 & 10,48 \\
13 Indústria Têxtil & 22,69 & 24,82 & 25,72 & 26,44 & 26,72 \\
14 Vestuário & 95,80 & 94,99 & 94,55 & 97,05 & 97,33 \\
15 Calçados e Couros & 71,84 & 74,41 & 79,04 & 81,35 & 77,96 \\
16 Produtos Alimentares & 70,82 & 70,25 & 70,22 & 70,86 & 71,76 \\
17 Diversos & 63,22 & 71,15 & 72,16 & 51,47 & 54,03 \\
18 Serviços industriais de U.P. & 30,76 & 32,55 & 32,50 & 32,22 & 31,89 \\
19 Construção Civil & 89,42 & 89,63 & 89,97 & 90,11 & 90,09 \\
20 Transporte e M. Comércio & 48,70 & 47,58 & 41,84 & 44,15 & 47,32 \\
21 Serviços & 58,93 & 66,18 & 55,34 & 49,24 & 61,21 \\
\hline
\end{tabular}

Fonte: IBGE - Matriz de Relações Intersetoriais - Brasil - 1990-1994 
Tabela 5.4

Participação das Exportações Brasileiras na Produção Total (em percentagem) 1990-1994

\begin{tabular}{lccccc}
\hline Setores & 1990 & 1991 & 1992 & 1993 & 1994 \\
\hline 1 Agropecuária & & & & & \\
2 Mineração & 2,21 & 2,42 & 2,65 & 2,69 & 2,73 \\
$\mathbf{3}$ Minerais não Metálicos & 20,54 & 27,53 & 27,40 & 28,35 & 24,99 \\
4 Metalurgia & 1,57 & 2,15 & 3,40 & 4,12 & 3,65 \\
$\mathbf{5}$ Mecânica e Material Elétrico & 12,25 & 15,21 & 16,80 & 15,48 & 13,67 \\
$\mathbf{6}$ Material de Transporte & 6,41 & 9,13 & 11,39 & 11,05 & 9,43 \\
$\mathbf{7}$ Madeira e Mobiliário & 12,71 & 16,53 & 21,98 & 19,66 & 16,30 \\
$\mathbf{8}$ Papel e Papelão & 3,82 & 5,81 & 9,23 & 12,45 & 10,77 \\
$\mathbf{9}$ Borracha & 7,05 & 7,83 & 11,22 & 10,71 & 11,68 \\
10 Indústria Quimica & 5,39 & 7,69 & 9,48 & 9,83 & 9,47 \\
11 Indústria Farmacêutica & 4,38 & 3,80 & 4,92 & 5,11 & 4,81 \\
12 Plásticos & 1,71 & 3,07 & 2,96 & 3,27 & 3,16 \\
13 Indústria Têxtil & 1,39 & 2,06 & 3,67 & 3,86 & 3,59 \\
14 Vestuário & 5,24 & 7,22 & 9,10 & 7,96 & 7,08 \\
15 Calçados e Couros & 1,21 & 1,67 & 2,66 & 2,93 & 2,74 \\
16 Produtos Alimentares & 23,24 & 30,00 & 44,85 & 43,01 & 36,66 \\
17 Diversos & 10,52 & 10,80 & 13,07 & 13,29 & 13,86 \\
18 Serviços Industriais de U.P. & 6,95 & 9,86 & 11,14 & 12,71 & 10,94 \\
19 Construção Civil & 0,00 & 0,00 & 0,00 & 0,00 & 0,00 \\
20 Transporte e M. Comércio & 5,00 & 0,00 & 0,00 & 0,00 & 0,00 \\
$\mathbf{2 1}$ Serviços & 0,59 & 5,17 & 5,74 & 4,43 & 4,99 \\
\hline
\end{tabular}

Fonte: IBGE - Matriz de Relaçōes Intersetoriais - Brasil - 1990-1994 


\subsection{3 insumos importados}

A Tabela 5.5 nos mostra a participação dos insumos importados na produção total, ou seja, os coeficientes de importação, para o periodo de 1990-1994. Tem havido um aumento constante do nivel de importação sobre o volume da produção total, o que reflete uma diminuição da "complexidade" da economia brasileira, na medida em que se passa a importar parte dos insumos necessários ao processo produtivo, a partir do estabelecimento do processo integracionista (MERCOSUL), o que tem resultado num menor nivel de ligações intersetoriais. As exceções são setores que dependem de insumos importados bastante especializados, os quais não podem ser substituidos no curto prazo. Levando-se em consideração os aumentos dos coeficientes de importação, cabe destacar os setores 6 - Material de Transporte; 13 - Indústria Têxtil, 5 - Mecânica e Material Elétrico e 15 - Calçados e Couros. Portanto, os maiores coeficientes de importação referem-se aos setores industriais. Os setores primário e de serviços apresentam baixo nivel de importação sobre o volume da produção total, com exceção do setor 18 - Serviços Industriais de Utilidade Pública e do setor 20 Transporte e Margem de Comércio. Observa-se, também, tendência de queda da participação das importações, o que provavelmente reflete uma mudança nos tipos de insumos utilizados. 
Tabela 5.5 - Participação dos insumos İmportados do MERCOSUL na Produção Total (\%) 1990-1994

\begin{tabular}{|c|c|c|c|c|c|}
\hline Setores & 1990 & 1991 & 1992 & 1993 & 1994 \\
\hline 1 Agropecuária & 0,74 & 0,81 & 0,83 & 1,24 & 0,88 \\
\hline 2 Mineração & 1,84 & 1,78 & 1,62 & 2,33 & 2,07 \\
\hline 3 Minerais não Metálicos & 1,75 & 1,47 & 1,52 & 2,01 & 1,78 \\
\hline 4 Metaiurgia & 4,21 & 5,60 & 5,22 & 4,85 & 4,61 \\
\hline 5 Mecânica e Material Elétrico & 4,60 & 6,49 & 6,20 & 6,92 & 7,55 \\
\hline 6 Material de Transporte & 3,66 & 4,24 & 4,79 & 5,66 & 5,37 \\
\hline 7 Madeira e Mobiliário & 0,98 & 1,00 & 1,15 & 1,33 & 1,08 \\
\hline 8 Papel e Papelão & 3,05 & 3,36 & 3,14 & 4,17 & 4,31 \\
\hline 9 Borracha & 5,01 & 6,28 & 5,66 & 5,99 & 6,67 \\
\hline 10 indústria Química & 12,12 & 12,11 & 11,13 & 9,13 & 9,62 \\
\hline 11 Indústria Farmacêutica & 8,90 & 11,02 & 9,29 & 9,07 & 10,73 \\
\hline 12 Plásticos & 2,01 & 2,99 & 3,10 & 3,36 & 3,95 \\
\hline 13 Indústria Têxtil & 2,84 & 4,02 & 4,56 & 7,82 & 7,38 \\
\hline 14 Vestuário & 0,80 & 1,08 & 1,09 & 1,95 & 2,56 \\
\hline 15 Calçados e Couros & 3,91 & 5,15 & 5,02 & 5,38 & 5,13 \\
\hline 16 Produtos Alimentares & 2,23 & 2,59 & 2,43 & 2,22 & 2,74 \\
\hline 17 Diversos & 1,42 & 1,67 & 1,91 & 2,55 & 2,59 \\
\hline 18 Serviços Industriais de U.P. & 5,10 & 6,92 & 5,90 & 4,15 & 3,82 \\
\hline 19 Construção Civil & 0,96 & 0,97 & 1,01 & 1,20 & 1,10 \\
\hline 20 Transporte e $M$. Comércio & 3,12 & 4,22 & 4,54 & 4,25 & 3,97 \\
\hline 21 Serviços & 0,59 & 0,73 & 0,69 & 0,81 & 1,05 \\
\hline
\end{tabular}

Fonte: IBGE - Matriz de Relações Intersetoriais - Brasil - 1990-1994. 


\subsection{Multiplicadores setoriais de produto}

Os multiplicadores setoriais fornecem informações que permitem determinar o impacto de diferentes estratégias setoriais sobre variáveis econômicas. Essas análises permitem visualizar a economia em questão e inferir como se comporta frente às políticas setoriais. Dessa forma, em 1990, os setores 6 - Material de Transporte, 4 Metalurgia, 16 - Produtos Alimentares e 15 - Calçados e Couros setores importantes que reagem com mais intensidade às variações em suas demandas finais, visto que apresentam os maiores multiplicadores de produto (Tabela 5.6). Em 1991, a partir da criação do MERCOSUL, os setores 16 - Produtos Alimentares, 6 - Material de Transporte e 4 - Metalurgia continuaram sendo os setores que apresentaram os maiores multiplicadores mudando apenas a ordem em relação ao ano de 1990 . O setor 13 - Indústria Têxtil apresenta o maior multiplicador apenas no ano de 1991. Os setores que apresentam os maiores multiplicadores em 1990 permanecem no ano de 1992 e 1994 apenas mudando a sua ordem.

Ainda, em 1993, os setores 4 - Metalurgia; 16 - Produtos Alimentares; 6 Material de Transporte apresentaram os maiores multiplicadores de produto. Estes resultados apontam para a importância destes setores na economia brasileira, sendo capazes de gerar grande impacto sobre o resto do sistema econômico. Neste ano o setor 8 - Papel e Papelão ocupou a quarta posição em relação aos cinco setores considerados neste trabalho que apresentaram os maiores multiplicadores.

Verifica-se, então, com a utilização do modelo de insumo-produto (através do multiplicador setorial do produto) os setores da economia brasileira afetados pela criação do MERCOSUL. A partir destes resultados, as estratégias que atuar sobre os setores 16 - Produtos Alimentares; 6 - Material de Transporte; 4 - Metalurgia; 13 Indústria Têxtil e 8 - Papel e Papelão pode resultar em maior impacto sobre a economia brasileira. Cabe ressaltar que o MERCOSUL é apenas um elemento que pode explicar estas mudanças. 
Como o multiplicador de produto na agricultura apresenta um indice de 1,75 , para o ano de 1990, um gasto simultâneo de uma unidade monetária no conjunto das atividades do setor agropecuário teria como resultado o aumento da produção de 1,75 unidades monetárias. Após a criação do MERCOSUL, o multiplicador de produto na agricultura apresenta um indice de 1,79, 1,75 e 1,65 para os anos de 1992, 1993 e 1994, respectivamente, ou seja, não se alterou de forma acentuada.

O mesmo pode ser observado para o setor de serviços que praticamente não se alterou, apresentando um indice de 1,37 em 1990 e, em 1994, um indice de 1,39. 
Tabela 5.6 - Multiplicador de Produto por Ramo da Atividade Econômica - Brasil - 1990-1994

\begin{tabular}{|c|c|c|c|c|c|}
\hline Setores & 1990 & 1991 & 1992 & 1993 & 1994 \\
\hline 1 Agropecuária & 1,7476 & 1,7389 & 1,7869 & 1,7509 & 1,6498 \\
\hline 2 iviineração & 1,8514 & 1,791 & 1,8449 & 1,9672 & 1,998 \\
\hline 3 Minerais não Metálicos & 2,1375 & 2,043 & 2,0866 & 2,0686 & 2,0202 \\
\hline 4 ivetaiurgia & 2,5029 & 2,3517 & 2,4292 & 2,4132 & 2,3952 \\
\hline 5 Mecânica e Material Elétrico & 2,1303 & 2,0021 & 1,9572 & 1,8822 & 1,8935 \\
\hline 6 iviateriai de Transporte & 2,5291 & 2,3914 & 2,386 & 2,3321 & 2,3266 \\
\hline 7 Madeira e Mobiliário & 2,1866 & 2,0733 & 2,1633 & 2,0756 & 2,0505 \\
\hline 8 Papel e Papelão & 2,3138 & 2,1743 & 2,3058 & 2,3453 & 2,3172 \\
\hline 9 Borracha & 2,3049 & 2,2304 & 2,2438 & 2,2141 & 2,2147 \\
\hline $10 \overline{\text { indústria Química }}$ & 2,0486 & 2,0454 & 1,9829 & 1,8036 & 1,8866 \\
\hline 11 Indústria Farmacêutica & 1,9743 & 2,0105 & 1,8763 & 1,8061 & 1,8006 \\
\hline 12 Plásticos & 2,0378 & 2,0577 & 2,0698 & 1,9639 & 2,0208 \\
\hline 13 Indústria Têxtil & 2,3661 & 2,4027 & 2,4145 & 2,2375 & 2,3121 \\
\hline 14 vestuário & 2,305 & 2,3408 & 2,3279 & 2,2531 & 2,2591 \\
\hline 15 Calçados e Couros & 2,4357 & 2,302 & 2,1562 & 2,1452 & 2,2124 \\
\hline 16 Produtos Alimentares & 2,4582 & 2,3977 & 2,4019 & 2,3852 & 2,3585 \\
\hline 17 Diversos & 1,9438 & 1,8809 & 1,892 & 1,9319 & 1,9294 \\
\hline 18 Serviços industriais de U.P. & 1,738 & 1,7629 & 1,7621 & 1,7757 & 1,7091 \\
\hline 19 Construção Civil & 1,8691 & 1,8409 & 1,8198 & 1,7618 & 1,685 \\
\hline 20 Transporte e M. Comércio & 1,6319 & 1,5745 & 1,6468 & 1,6817 & 1,6246 \\
\hline 21 Serviços & 1,3711 & 1,353 & 1,3231 & 1,323 & 1,387 \\
\hline
\end{tabular}

Fonte: Dados Elaborados pela Pesquisa

Os resultados apresentados nas tabelas 5.7 a 5.11 nos indicam que, a formação do MERCOSUL não provocou mudanças profundas na estrutura de insumos importados.

Os cinco setores que apresentaram os maiores multiplicadores de produtos importados da Argentina, em 1990, foram: 5 - Mecânica e Material Elétrico (0,0147); 15 - Calçados e Couros (0,0108); 16 - Produtos Alimentares (0,0093); 8 - Papel e Papelão $(0,0069)$ e 6 - Material de Transporte $(0,0061)$. 
A partir da criação do MERCOSUL, em 1991, os setores que apresentaram os maiores multiplicadores, foram 15 - Calçados e Couros $(0,0241) ; 5$ - Mecânica e Material Elétrico (0,0179); 16 - Produtos Alimentares $(0,0117) ; 13$ - Indústria Têxtil $(0,0094)$ e 6 - Material de Transporte $(0,0092)$. Os mesmos setores continuaram apresentando os maiores multiplicadores em 1992, apenas mudando a ordem no caso dos setores Têxtil e Material de Transporte.

Em 1993, os maiores multiplicadores, em ordem decrescente, foram os relacionados aos setores 17 - Diversos; 11 - Indústria Farmacêutica; 7 - Madeira e Mobiliário; 14 - Vestuário e 4 - Metalurgia. Já em 1994, os resultados foram, em ordem decrescente, 15 - Calçados e Couros; 13 - Indústria Têxtil; 6 - Material de Transporte; 16 - Produtos Alimentares e 14 - Vestuário.

Em relação ao Paraguai, no ano de 1990 , os setores que apresentaram os maiores multiplicadores foram: 13 - Indústria Têxtil; 14 - Vestuário; 7 - Madeira e Mobiliário; 16 - Produtos Alimentares e 9 - Borracha. Esta situação se mantém praticamente no ano de 1991, apresentando apenas uma mudança de ordem entre os setores 16 - Produtos Alimentares e 5 - Borracha.

A partir de 1992, quatro setores continuam apresentando os maiores multiplicadores, mas o setor 16 - Produtos Alimentares perde a sua posição pelo setor 3 - Indústria Farmacêutica. Em 1993 os maiores valores são apresentados nos setores: 14 - Vestuário; 12 - Plásticos; 17 - Diversos; 15 - Calçados e Couros e 8 - Papel e Papelão. Já em 1994, tem-se, em ordem decrescente, 13 - Indústria Têxtil; 14 Vestuário; 16 - Produtos Alimentares; 7 - Madeira e Mobiliário e 11 - Indústria Farmacêutica.

Os cinco maiores multiplicadores setoriais do Uruguai nos anos 1990 e 1991 foram: 15 - Calçados e Couros; 9 - Borracha; 5 - Mecânica e Material Elétrico; 11 Indústria Farmacêutica e 16 - Produtos Alimentares. Em 1992, o setor 9 - Borracha perde a sua ordem para o setor 13 - Têxtil, sendo que os outros resultados não se alteraram. Já em 1993, apenas o setor 11 - Indústria Farmacêutica continua 
apresentando um dos maiores multiplicadores e, em 1994, continua entre os cinco maiores os setores 11 - Indústria Farmacêutica e 14 - Vestuário.

Os multiplicadores setoriais de importação, no caso do Chile, não apresentaram mudanças significativas em relação à formação do MERCOSUL. Em relação à Bolívia os multiplicadores setoriais de produção apresentaram valores próximos de zero, então, para se produzir uma unidade monetária, praticamente nada se importou da Bolívia no periodo analisado.

Por último, os cinco maiores multiplicadores de produtos importados do Resto do Mundo são: 10 - Indústria Química; 11 - Indústria Farmacêutica; 9 - Borracha; 4 Metalurgia e 6 - Material de Transporte, no período 1990-1992. As mudanças começam a ocorrer a partir de 1993, onde os maiores multiplicadores estão nos setores: 11 Indústria Farmacêutica; 7 - Mecânica e Material Elétrico; 17 - Diversos; 14 - Vestuário e 9 - Borracha, em ordem decrescente. Já em 1995, os setores são: 11 - Indústria Farmacêutica; 10 - Indústria Química; 9 - Borracha; 13 - Indústria Têxtil e 5 - Madeira e Mobiliário. Observa-se tanto mudanças na ordem quanto nos setores.

Em relação à Argentina pode-se perceber que ao longo do tempo a economia brasileira diminuiu a utilização de importados em seu processo produtivo. 0 setor 5 Mecânica e Material Elétrico, de 1990 para 1991 aumentou 69,4\%, mas, de 1991 para 1992 reduziu em (-20,5\%); em 1993 para (-84,6\%) e, em 1994 (-96,2\%). O mesmo pode ser verificado para os outros quatro setores considerados nesta análise. Tendo os insumos importados uma participação relevante no custo de produção da indústria e sendo as tarifas alfandegárias para os insumos diferentes entre um pais e outro, a firma de um país que fixou taxas mais baixas para a importação de insumos tenderá a ficar com uma fatia maior do mercado regional, pois seus custos de produção são menores. O comportamento é o mesmo em relação ao Paraguai e Uruguai, apenas ressalta-se que o setor 14 - Vestuário apresentou um multiplicador da ordem de 0,0063, em 1992, passando para 0,0166 em 1993, ou seja, apresentou um crescimento de $163 \%$. 
Para efeito de análise, os resultados apresentados nas tabelas 5.12 a $5.210 u$ seja, a produção destinada ao consumo das famílias e do governo; a formação bruta de capital; as exportações totais brasileiras; e, a produção destinada as exportações para a Argentina, Paraguai, Uruguai, Chile, Bolívia e Resto do Miundo, estão em valores monetários a preços de 1994, corrigidos utilizando o IGPDI da FGV. Os deflatores utilizados foram: para o ano de 1990 (0,008899); 1991 (0,001534); $1992(0,000122)$ e $1993(0,004341)$. Cabe ressaltar que as análises realizadas a partir de valores monetários podem apresentar distorções, principalmente quando os países apresentam altas taxas de inflação, merecendo assim atenção especial.

Ao longo do periodo pode-se notar que a análise da evolução do valor da produção destinada como função dos quatro componentes da demanda final (consumo das famílias, gastos do governo, exportações e formação bruta de capital) revelou pequenas variações para a maioria dos setores apresentados neste trabalho. Em relação ao consumo das famílias o valor da produção setorial foi decrescendo gradativamente entre 1990-1993, apresentando aumentos significativos a partir de 1994. Essas reduções variam de $(-33,3 \%)$ a $(-16,4 \%)$, considerando-se as maiores variações setoriais ocorridas antes da formação do MERCOSUL (1991), a saber: 14 Vestuário (-33,3\%); 15 - Calçados e Couros (-32,4\%); 6 - Material de Transporte (27,8\%), 13 - Indústria Têxtil (-27,4\%) e 7 - Madeira e Miobiliário (-26,7\%) (Tabela 5.12).

Também decresceu a produção destinada ao governo (Tabela 5.13). Ao longo do período analisado o setor 14 - Vestuário, apresentou redução da ordem de $(-21,1 \%)$, $(-29,6 \%)$ e $(-50,4 \%)$, de 1990-1993.

A parcela da produção destinada à formação bruta de capital decresceu entre 1990-1993 em relação a todos os setores considerados nesta pesquisa, apresentando variações em média da ordem de (-35\%) (Tabela 5.14).

De 1990 para 1991 a produção exportada para a Argentina apresentou crescimento em todos os setores analisados. As maiores taxas de crescimento foram: 15 - Calçados e Couros (450,3\%); 8 - Papel e Papelão (311,2\%); 6 - Material de 
Transporte (276,2\%); 9 - Borracha (255,3\%) e 11 - Indústria Farmacêutica (237,5\%). A partir da criação do NiERCOSUL as taxas de crescimento nesses setores são menores, chegando a taxas negativas em quatro dos cinco setores analisados, voitando a apresentar taxas crescentes a partir de 1993 (Tabela 5.16).

Para o Paraguai e o Uruguai verifica-se o mesmo comportamento. Ressalta-se o crescimento observado de 1990-1991, no setor 11 - Indústria Farmacêutica de 627,4\% e em relação ao Uruguai, o crescimento do setor 6 - Material de Transporte, de 1992 a 1993, de 3 041\%. (tabelas 5.19 e 5.20). A produção destinada para exportações para o Resto do Miundo não apresentou mudanças significativas no período anaiisado. (tabelas 5.17 e 5.18$)$.

Tabeia 5.7 - Muitipiicadior Setorial de Produtos importados - Argentina - 1990-1994

\begin{tabular}{lccccc}
\hline Setores & $\mathbf{1 9 9 0}$ & $\mathbf{1 9 9 1}$ & $\mathbf{1 9 9 2}$ & $\mathbf{1 9 9 3}$ & $\mathbf{1 9 9 4}$ \\
\hline $\mathbf{1}$ Agropecuária & 0,0025 & 0,0033 & 0,0032 & 0,003 & 0,0032 \\
$\mathbf{2}$ Mineração & 0,005 & 0,006 & 0,0039 & 0,0018 & 0,0023 \\
$\mathbf{3}$ Minerais não Metálicos & 0,004 & 0,0049 & 0,0034 & 0,0023 & 0,0032 \\
$\mathbf{4}$ Metalurgia & 0,0055 & 0,0072 & 0,0056 & 0,0076 & 0,007 \\
$\mathbf{5}$ Mecânica e Material Elétrico & 0,0147 & 0,0249 & 0,0179 & 0,0024 & 0,0035 \\
$\mathbf{6}$ Materiai de Transporte & 0,0061 & 0,0084 & 0,0092 & 0,0036 & 0,0133 \\
$\mathbf{7}$ Madeira e Mobiliário & 0,0036 & 0,0037 & 0,0033 & 0,0332 & 0,0031 \\
$\mathbf{8}$ Papel e Papeläo & 0,0069 & 0,006 & 0,0043 & 0,0037 & 0,0039 \\
$\mathbf{9}$ Borracha & 0,0054 & 0,0072 & 0,0065 & 0,0046 & 0,0092 \\
$\mathbf{1 0}$ indústria Química & 0,0045 & 0,0069 & 0,0065 & 0,0013 & 0,0104 \\
$\mathbf{1 1}$ Indústria Farmacêutica & 0,0042 & 0,0056 & 0,0048 & 0,0456 & 0,0071 \\
$\mathbf{1 2}$ Plásticos & 0,0032 & 0,0051 & 0,0047 & 0,005 & 0,0057 \\
$\mathbf{1 3}$ Indústria Têxtil & 0,0055 & 0,0084 & 0,0094 & 0,0018 & 0,0164 \\
$\mathbf{1 4}$ Vestuário & 0,0039 & 0,0059 & 0,0059 & 0,0108 & 0,0114 \\
$\mathbf{1 5}$ Calçados e Couros & 0,0108 & 0,0303 & 0,0241 & 0,0037 & 0,0191 \\
$\mathbf{1 6}$ Produtos Alimentares & 0,0093 & 0,0112 & 0,0117 & 0,0035 & 0,0119 \\
$\mathbf{1 7}$ Diversos & 0,0034 & 0,0042 & 0,0032 & 0,0787 & 0,003 \\
$\mathbf{1 8}$ Serviços industriais de U.P. & 0,0033 & 0,006 & 0,0036 & 0,001 & 0,0007 \\
$\mathbf{1 9}$ Construção Civil & 0,0035 & 0,0044 & 0,0031 & 0,0022 & 0,0018 \\
$\mathbf{2 0}$ Transporte e M. Comércio & 0,0015 & 0,0023 & 0,0025 & 0,0009 & 0,003 \\
$\mathbf{2 1}$ Serviços & 0,0011 & 0,0015 & 0,0011 & 0,0011 & 0,0013 \\
\hline
\end{tabular}


Tabela 5.8 - Multiplicador Setorial de Produtos Importados - Paraguai - 1990-1994

\begin{tabular}{llllll}
\hline Setores & 1990 & 1991 & 1992 & 1993 & 1994 \\
\hline 1 Agropecuária & 0,0004 & 0,0002 & 0,0002 & 0,0001 & 0,0002 \\
$\mathbf{2}$ Mineração & 0,0001 & 0,0001 & 0,0001 & 0,0001 & 0,0001 \\
$\mathbf{3}$ Minerais não Metálicos & 0,0002 & 0,0002 & 0,0001 & 0,0001 & 0,0001 \\
$\mathbf{4}$ Metalurgia & 0,0001 & 0,0001 & 0,0001 & 0,0002 & 0,0001 \\
$\mathbf{5}$ Mecânica e Material Elétrico & 0,0002 & 0,0002 & 0,0001 & 0,0002 & 0,0001 \\
$\mathbf{6}$ Material de Transporte & 0,0002 & 0,0002 & 0,0002 & 0,0002 & 0,0002 \\
$\mathbf{7}$ Madeira e Mobiliário & 0,0019 & 0,0012 & 0,0015 & 0,0004 & 0,0008 \\
$\mathbf{8}$ Papel e Papelão & 0,0002 & 0,0002 & 0,0002 & 0,0012 & 0,0002 \\
$\mathbf{9}$ Borracha & 0,0009 & 0,001 & 0,0009 & 0,0003 & 0,001 \\
$\mathbf{1 0}$ Indústria Quimica & 0,0002 & 0,0001 & 0,0001 & 0,0001 & 0,0001 \\
$\mathbf{1 1}$ Indústria Farmacêutica & 0,0002 & 0,0002 & 0,0017 & 0,0005 & 0,0007 \\
$\mathbf{1 2}$ Plásticos & 0,0002 & 0,0003 & 0,0002 & 0,0068 & 0,0002 \\
$\mathbf{1 3}$ Indústria Têxtil & 0,0067 & 0,0097 & 0,0106 & 0,0002 & 0,0096 \\
$\mathbf{1 4}$ Vestuário & 0,0043 & 0,0062 & 0,0063 & 0,0166 & 0,0068 \\
$\mathbf{1 5}$ Calçados e Couros & 0,0008 & 0,0007 & 0,0009 & 0,0039 & 0,002 \\
$\mathbf{1 6}$ Produtos Alimentares & 0,0015 & 0,0008 & 0,0008 & 0,0004 & 0,0012 \\
$\mathbf{1 7}$ Diversos & 0,0003 & 0,0003 & 0,0003 & 0,0047 & 0,0003 \\
$\mathbf{1 8}$ Serviços Industriais de U.P. & 0,0001 & 0,0001 & 0,0001 & 0,0001 & 0 \\
$\mathbf{1 9}$ Construção Civil & 0,0002 & 0,0002 & 0,0001 & 0,0002 & 0,0001 \\
$\mathbf{2 0}$ Transporte e M. Comércio & 0,0001 & 0,0001 & 0,0001 & 0,0001 & 0,0001 \\
$\mathbf{2 1}$ Serviços & 0,0001 & 0,0001 & 0,0001 & 0,0001 & 0,0001 \\
\hline
\end{tabular}

Tabela 5.9 - Multiplicador Setorial de Produtos Importados - Uruguai - 1990-1994

\begin{tabular}{lccccc}
\hline Setores & 1990 & 1991 & 1992 & 1993 & 1994 \\
\hline 1 Agropecuária & 0,001 & 0,0009 & 0,0006 & 0,0006 & 0,0005 \\
$\mathbf{2}$ Mineração & 0,0013 & 0,0011 & 0,0007 & 0,0003 & 0,0002 \\
$\mathbf{3}$ Minerais não Metálicos & 0,0011 & 0,0009 & 0,0006 & 0,0004 & 0,0003 \\
$\mathbf{4}$ Metalurgia & 0,0014 & 0,0011 & 0,0009 & 0,0006 & 0,0003 \\
$\mathbf{5}$ Mecânica e Material Elétrico & 0,0039 & 0,0045 & 0,0023 & 0,0003 & 0,0003 \\
$\mathbf{6}$ Material de Transporte & 0,0016 & 0,0013 & 0,001 & 0,0004 & 0,0009 \\
$\mathbf{7}$ Madeira e Mobiliário & 0,0011 & 0,0008 & 0,0007 & 0,0013 & 0,0005 \\
$\mathbf{8}$ Papel e Papelão & 0,0014 & 0,0012 & 0,0013 & 0,0007 & 0,0004 \\
$\mathbf{9}$ Borracha & 0,005 & 0,0037 & 0,003 & 0,0009 & 0,003 \\
$\mathbf{1 0}$ Indústria Química & 0,0017 & 0,0015 & 0,0011 & 0,0004 & 0,0005 \\
$\mathbf{1 1}$ Indústria Farmacêutica & 0,0035 & 0,0057 & 0,0033 & 0,0033 & 0,0019 \\
$\mathbf{1 2}$ Plásticos & 0,0014 & 0,0013 & 0,001 & 0,0022 & 0,0006 \\
$\mathbf{1 3}$ Indústria Têxtil & 0,0026 & 0,0031 & 0,0031 & 0,0004 & 0,0028 \\
$\mathbf{1 4}$ Vestuário & 0,0019 & 0,002 & 0,002 & 0,0035 & 0,002 \\
$\mathbf{1 5}$ Calçados e Couros & 0,0205 & 0,0085 & 0,0045 & 0,0011 & 0,0031 \\
$\mathbf{1 6}$ Produtos Alimentares & 0,0034 & 0,0032 & 0,0022 & 0,0007 & 0,0025 \\
$\mathbf{1 7}$ Diversos & 0,001 & 0,0008 & 0,0008 & 0,0159 & 0,0005 \\
$\mathbf{1 8}$ Serviços Industriais de U.P. & 0,0009 & 0,0011 & 0,0006 & 0,0002 & 0,0001 \\
$\mathbf{1 9}$ Construção Civil & 0,0009 & 0,0008 & 0,0005 & 0,0003 & 0,0002 \\
$\mathbf{2 0}$ Transporte e M. Comércio & 0,0006 & 0,0006 & 0,0004 & 0,0002 & 0,0003 \\
$\mathbf{2 1}$ Serviços & 0,0003 & 0,0004 & 0,0003 & 0,0002 & 0,0002 \\
\hline
\end{tabular}


Tabela 5.10 - Multiplicador Setorial de Produtos Importados - Chile - 1990-1994

\begin{tabular}{lccccc}
\hline Setores & $\mathbf{1 9 9 0}$ & $\mathbf{1 9 9 1}$ & $\mathbf{1 9 9 2}$ & $\mathbf{1 9 9 3}$ & $\mathbf{1 9 9 4}$ \\
\hline $\mathbf{1}$ Agropecuária & 0,0006 & 0,0005 & 0,0004 & 0,0004 & 0,0006 \\
$\mathbf{2}$ Mineração & 0,0006 & 0,0005 & 0,0003 & 0,0004 & 0,0006 \\
$\mathbf{3}$ Minerais não Metálicos & 0,0007 & 0,0007 & 0,0015 & 0,0016 & 0,0017 \\
$\mathbf{4}$ Metalurgia & 0,0013 & 0,0016 & 0,0013 & 0,0012 & 0,0012 \\
$\mathbf{5}$ Mecânica e Material Elétrico & 0,0015 & 0,0015 & 0,0007 & 0,0005 & 0,0007 \\
$\mathbf{6}$ Material de Transporte & 0,0009 & 0,0009 & 0,0007 & 0,0008 & 0,0008 \\
$\mathbf{7}$ Madeira e Mobiliário & 0,0015 & 0,0016 & 0,0012 & 0,0009 & 0,001 \\
$\mathbf{8}$ Papel e Papelão & 0,003 & 0,0048 & 0,0015 & 0,0011 & 0,0028 \\
$\mathbf{9}$ Borracha & 0,0012 & 0,0012 & 0,0009 & 0,0054 & 0,0018 \\
$\mathbf{1 0}$ Indústria Química & 0,0011 & 0,0012 & 0,001 & 0,0002 & 0,002 \\
$\mathbf{1 1}$ Indústria Farmacêutica & 0,0062 & 0,0069 & 0,0013 & 0,005 & 0,0017 \\
$\mathbf{1 2}$ Plásticos & 0,0008 & 0,0011 & 0,0008 & 0,0014 & 0,0018 \\
$\mathbf{1 3}$ Indústria Têxtil & 0,0011 & 0,001 & 0,0007 & 0,0005 & 0,0015 \\
$\mathbf{1 4}$ Vestuário & 0,0007 & 0,0007 & 0,0004 & 0,0011 & 0,0009 \\
$\mathbf{1 5}$ Calçados e Couros & 0,001 & 0,0019 & 0,0007 & 0,0007 & 0,001 \\
$\mathbf{1 6}$ Produtos Alimentares & 0,0018 & 0,0017 & 0,0014 & 0,0004 & 0,0014 \\
$\mathbf{1 7}$ Diversos & 0,0006 & 0,0007 & 0,0005 & 0,0084 & 0,0008 \\
$\mathbf{1 8}$ Serviços Industriais de U.P. & 0,0003 & 0,0004 & 0,0002 & 0,0002 & 0,0001 \\
$\mathbf{1 9}$ Construção Civil & 0,0006 & 0,0006 & 0,0012 & 0,0004 & 0,001 \\
$\mathbf{2 0}$ Transporte e M. Comércio & 0,0004 & 0,0005 & 0,0004 & 0,0007 & 0,0007 \\
$\mathbf{2 1}$ Serviços & 0,0002 & 0,0003 & 0,0001 & 0,0002 & 0,0002 \\
\hline
\end{tabular}

Tabela 5.11 - Multiplicador Setorial de Produtos Im portados - Resto do Mundo - 1990-1994

\begin{tabular}{|c|c|c|c|c|c|}
\hline Setores & 1990 & 1991 & 1992 & 1993 & 1994 \\
\hline 1 Agropecuária & 0,0325 & 0,0344 & 0,0341 & 0,0196 & 0,0263 \\
\hline 2 Mineração & 0,0315 & 0,0311 & 0,0317 & 0,0272 & 0,043 \\
\hline 3 Minerais não Metálicos & 0,0475 & 0,0434 & 0,0452 & 0,0329 & 0,0455 \\
\hline 4 Metalurgia & 0,0859 & 0,1033 & 0,1017 & 0,0834 & 0,0904 \\
\hline 5 Mecânica e Material Elétrico & 0,0653 & 0,0774 & 0,0801 & 0,0445 & 0,107 \\
\hline 6 Material de Transporte & 0,0807 & 0,0897 & 0,093 & 0,1182 & 0,0944 \\
\hline 7 Madeira e Mobiliário & 0,036 & 0,0373 & 0,0407 & 0,1541 & 0,0347 \\
\hline 8 Papel e Papelão & 0,0609 & 0,0636 & 0,0677 & 0,0245 & 0,0813 \\
\hline 9 Borracha & 0,1015 & 0,1184 & 0,1099 & 0,1368 & 0,1164 \\
\hline 10 Indústria Química & 0,1631 & 0,1652 & 0,1489 & 0,0148 & 0,1232 \\
\hline 11 Indústria Farm acê utica & 0,113 & 0,1327 & 0,1146 & 0,6717 & 0,1235 \\
\hline 12 Plásticos & 0,0741 & 0,0877 & 0,0862 & 0,1203 & 0,0872 \\
\hline 13 Indústria Têxtil & 0,0601 & 0,0762 & 0,0822 & 0,0304 & 0,112 \\
\hline 14 Vestuário & 0,0376 & 0,0479 & 0,0499 & 0,1412 & 0,073 \\
\hline 15 Calçados e Couros & 0,0563 & 0,0619 & 0,0617 & 0,0447 & 0,0722 \\
\hline 16 Produtos Alimentares & 0,0401 & 0,0451 & 0,0423 & 0,0194 & 0,0411 \\
\hline 17 Diversos & 0,036 & 0,0389 & 0,0397 & 0,1508 & 0,0473 \\
\hline 18 Serviços Industriais de U.P. & 0,0174 & 0,0228 & 0,0216 & 0,0114 & 0,0149 \\
\hline 19 Construção Civil & 0,0304 & 0,0328 & 0,0326 & 0,0201 & 0,0298 \\
\hline 20 Transporte e $M$. Comércio & 0,035 & 0,039 & 0,0415 & 0,0156 & 0,037 \\
\hline 21 Serviços & 0,0099 & 0,0111 & 0,0101 & 0,0105 & 0,0137 \\
\hline
\end{tabular}


Tabela 5.12 - Produção Destinada ao Consumo das Familias - 1990-1994 (milhões de 1994)

\begin{tabular}{|c|c|c|c|c|c|}
\hline Setores & 1990 & 1991 & 1992 & 1993 & 1994 \\
\hline 1 Agropecuária & 25685,09 & 22317,78 & 19292.57 & 15240,45 & 36845,46 \\
\hline 2 Mineração & 3280,40 & 2452,93 & 2131.14 & 1342,73 & 2498,74 \\
\hline 3 Minerais não Metálicos & 1841,99 & 1583,72 & 1275,81 & 893,32 & 1912,37 \\
\hline 4 Metalurgia & 9014,63 & 6946,82 & 5760.37 & 4014,79 & 8827,04 \\
\hline 5 Mecânica e Materiai Elétrico & 9887,93 & 7497,29 & 6153.98 & 4426,03 & 9415,69 \\
\hline 6 Material de Transporte & 7112,08 & 5136,09 & 4180,75 & 3339,94 & 8061,97 \\
\hline 7 Madeira e Mobiliário & 3435,70 & 2517,77 & 1882,55 & 1573,19 & 3455,17 \\
\hline 8 Papel e Papelão & 5662,29 & 5340,26 & 3953,31 & 2655,51 & 5476,12 \\
\hline 9 Borracha & 1528,17 & 1255,01 & 1053,45 & 748,85 & 1587,04 \\
\hline 10 Indústria Química & 24985,11 & 20266,48 & 19030.74 & 15635,84 & 28122,34 \\
\hline 11 Indústria Farmacêutica & 4205,71 & 3274,58 & 3380.19 & 2788,22 & 5159,11 \\
\hline 12 Plásticos & 2379,42 & 1787,22 & 1402.00 & 1073,38 & 2039,79 \\
\hline 13 indústria Têxtil & 9299,43 & 6747,38 & 5116.94 & 3797,26 & 7419,69 \\
\hline 14 Vestuário & 6523,67 & 4349,37 & 3406,17 & 2605,56 & 4994,42 \\
\hline 15 Calçados e Couros & 2628,71 & 1777,36 & 1180,08 & 986,05 & 1902,29 \\
\hline 16 Produtos Alimentares & 29784,95 & 27169,98 & 23480.78 & 18589,51 & 39291,42 \\
\hline 1T Diversos & 2173,37 & 1796,14 & 1520.82 & 1091,04 & 2249,12 \\
\hline 18 Serviços Industriais de U.P. & 9323,96 & 9321,91 & 8730,81 & 6823,76 & 13313,70 \\
\hline 19 Construção Civil & 1138,99 & 1092,17 & 831,95 & 584,54 & 1445,61 \\
\hline 20 Transporte e $M$. Comércio & 43059,07 & 34672,70 & 29663,61 & 24180,01 & 47367,83 \\
\hline 21 Serviços & 65232,16 & 74732,87 & 60867.08 & 44043,65 & 87770,11 \\
\hline
\end{tabular}

Tabela 5.13 - Produção Destinada ao Consumo do Governo - 1990-1994 (milhões de 1994)

\begin{tabular}{|c|c|c|c|c|c|}
\hline Setores & 1990 & 1991 & 1992 & 1993 & 1994 \\
\hline 1 Agropecuária & 1135,31 & 949,56 & 692,58 & 578,18 & 1687,09 \\
\hline 2 Mineração & 257,32 & 186,02 & 136,75 & 87,15 & 202,64 \\
\hline 3 Minerais não Metálicos & 243,53 & 193,95 & 137,18 & 100,72 & 262,94 \\
\hline 4 Metalurgia & 784,61 & 583,58 & 439,57 & 302,43 & 749,94 \\
\hline 5 Mecânica e Material Elétrico & 708,88 & 535,67 & 414,38 & 305,70 & 668,40 \\
\hline 6 Material de Transporte & 704,24 & 460,35 & 373,40 & 256,49 & 658,37 \\
\hline 7 Madeira e Mobiliário & 107,87 & 81,35 & 54,06 & 43,44 & 118,26 \\
\hline 8 Papel e Papelão & 1124,47 & 982,14 & 667,32 & 477,42 & 1201,09 \\
\hline 9 Borracha & 343,23 & 267,03 & 210,28 & 149,18 & 360,69 \\
\hline 10 Indústria Química & 1770,68 & 1386,28 & 1095,23 & 873,85 & 1983,91 \\
\hline 11 Indústria Farmacêutica & 186,16 & 109,45 & 102,16 & 82,47 & 145,72 \\
\hline 12 Plásticos & 224,36 & 173,41 & 120,51 & 94,51 & 219,88 \\
\hline 13 Indústria Têxtil & 440,06 & 332,60 & 224,60 & 166,00 & 392,09 \\
\hline 14 Vestuário & 23,63 & 18,63 & 13,12 & 6,50 & 15,26 \\
\hline 15 Calçados e Couros & 27,34 & 20,84 & 13,14 & 7,75 & 19,95 \\
\hline 16 Produtos Alimentares & 1353,00 & 1189,80 & 871,16 & 708,47 & 1863,91 \\
\hline 17 Diversos & 243,81 & 193,64 & 142,58 & 174,13 & 426,06 \\
\hline 18 Serviços Industriais de U.P. & 1096,12 & 934,10 & 750,27 & 582,62 & 1403,76 \\
\hline 19 Construção Civil & 701,77 & 522,41 & 374,26 & 294,61 & 826,68 \\
\hline 20 Transporte e $M$. Comércio & 3076,15 & 2610,99 & 1886,57 & 1595,83 & 3875,27 \\
\hline 21 Serviços & 60370,15 & 50057,04 & 40011,04 & 32595,67 & 69716,45 \\
\hline
\end{tabular}


Tabela 5.14 - Produção Destinada a Formação Bruta de Capital - 1990-1994 (milhões de 1994)

\begin{tabular}{|c|c|c|c|c|c|}
\hline Setores & 1990 & 1991 & 1992 & 1993 & 1994 \\
\hline 1 Agropecuária & 1930,78 & 1480,03 & 1387,93 & 1132,45 & 3006,07 \\
\hline 2 Mineração & $1382,1 i$ & 954,87 & 786,21 & 552,44 & 1087,02 \\
\hline 3 Minerais não Metálicos & 5313,90 & 4499,49 & 3700,57 & 2793,01 & 5744,00 \\
\hline 4 Metalurgia & 9674,52 & 7106,75 & 5887,02 & 4602,44 & 10039,95 \\
\hline 5 Mecânica e Material Elétrico & 12743,90 & 8016,61 & 6694,76 & 5043,62 & 12132,81 \\
\hline 6 iviaterial de Transporie & 4864,89 & 3200,25 & 2478,53 & 2388,34 & 5502,30 \\
\hline 7 Madeira e Mobiliário & 2427,62 & 1771,89 & 1304,88 & 1088,47 & 2335,13 \\
\hline 8 Papel e Papelão & 883,20 & 711,65 & 506,98 & 338,88 & 710,27 \\
\hline 9 Borracha & 606,82 & 426,59 & 348,64 & 278,89 & 598,70 \\
\hline 10 Indústria Química & 5164,19 & 3751,62 & 3367,50 & 2615,12 & 5161,96 \\
\hline 11 Indústria Farmacêutica & 53,16 & 34,23 & 32,39 & 21,86 & 41,59 \\
\hline 12 Plásticos & 1396,43 & 1023,93 & 790,41 & 620,16 & 1174,52 \\
\hline 13 Indústria Têxtil & 421,01 & 285,83 & 214,69 & 140,04 & 286,45 \\
\hline 14 Vestuário & 63,08 & 42,54 & 33,60 & 14,77 & 26,03 \\
\hline 15 Calçados e Couros & 50,99 & 33,69 & 24,04 & 12,53 & 27,83 \\
\hline 16 Produtos Alimentares & 435,85 & 349,36 & 300,32 & 189,56 & 433,44 \\
\hline 17 Diversos & 640,30 & 447,51 & 363,49 & 268,28 & 558,86 \\
\hline 18 Serviços Industriais de U.P. & 1463,30 & 1338,05 & 1175,60 & 744,88 & 1578,61 \\
\hline 19 Construção Civil & 39264,54 & 31724,58 & 27333,79 & 22825,22 & 48875,69 \\
\hline 20 Transporte e M. Comércio & 8521,21 & 6249,61 & 5054,38 & 4197,11 & 8375,81 \\
\hline 21 Servicos & 4657.37 & 3502.16 & 3055.93 & 2591.46 & 5154.55 \\
\hline
\end{tabular}

Tabela 5.15 - Produção Destinada as Exportações Totais Brasileiras - 1990-1994 (milhões de 1994)

\begin{tabular}{lccccc}
\hline \multicolumn{1}{c}{ Setores } & $\mathbf{1 9 9 0}$ & $\mathbf{1 9 9 1}$ & $\mathbf{1 9 9 2}$ & $\mathbf{1 9 9 3}$ & $\mathbf{1 9 9 4}$ \\
\hline & & & & & \\
1 Agropecuária & 3359,37 & 3014,37 & 3352,87 & 2699,82 & 6391,58 \\
2 Mineração & 2166,68 & 2255,68 & 2099,47 & 1394,11 & 2331,98 \\
3 Minerais não Metálicos & 593,22 & 613,99 & 652,45 & 534,82 & 982,50 \\
4 Metalurgia & 7447,22 & 7378,31 & 7739,84 & 5623,39 & 9915,84 \\
5 Mecânica e Material Elétrico & 3280,67 & 3137,96 & 3501,12 & 2686,83 & 4488,05 \\
6 Material de Transporte & 2859,06 & 2798,76 & 3261,72 & 2560,78 & 4462,25 \\
7 Madeira e Mobiliário & 431,03 & 460,72 & 541,42 & 588,71 & 1068,71 \\
8 Papel e Papelão & 1303,26 & 1426,18 & 1507,29 & 1020,79 & 2014,99 \\
9 Borracha & 553,32 & 576,46 & 656,80 & 545,16 & 968,16 \\
10 Indústria Química & 4293,47 & 3709,13 & 4351,21 & 3586,13 & 6319,02 \\
11 Indústria Farmacêutica & 124,77 & 146,65 & 158,07 & 138,23 & 237,66 \\
12 Plásticos & 421,59 & 406,65 & 456,15 & 383,18 & 635,89 \\
13 indústria Têxtil & 1329,86 & 1359,79 & 1359,57 & 905,74 & 1544,80 \\
14 Vestuário & 122,89 & 116,93 & 137,87 & 99,32 & 170,48 \\
15 Calçados e Couros & 1120,08 & 1078,62 & 1337,28 & 1041,99 & 1549,29 \\
16 Produtos Alimentares & 4991,66 & 4925,60 & 5228,25 & 4155,45 & 8883,63 \\
17 Diversos & 468,06 & 461,61 & 474,41 & 369,86 & 623,60 \\
18 Serviços Industriais de U.P. & 900,49 & 1090,34 & 1254,02 & 806,90 & 1450,55 \\
19 Construção Civil & 94,78 & 87,46 & 91,80 & 83,47 & 168,37 \\
20 Transporte e M. Comércio & 2877,87 & 2556,14 & 3185,97 & 4222,62 & 6924,53 \\
21 Serviços & 1893,23 & 1696,87 & 2079,87 & 2633,29 & 4305,66 \\
\hline
\end{tabular}


Tabela 5.16 - Produção Destinada as Exportações para a Argentina - 1990-1994 (milhões de 1994)

\begin{tabular}{|c|c|c|c|c|c|}
\hline Setores & 1990 & 1991 & 1992 & 1993 & 1994 \\
\hline 1 Ágropecuária & 67,43 & 98,34 & 130,65 & 114,48 & 279,66 \\
\hline 2 Mineração & 55,69 & 73,60 & 127,31 & 163,13 & 279,36 \\
\hline 3 Minerais não Metálicos & 18,78 & 30,57 & 46,44 & 49,33 & 92,49 \\
\hline 4 Metalurgia & 208,94 & 496,93 & 819,38 & 659,57 & 1228,29 \\
\hline 5 Mecânica e Material Elétrico & 117,37 & 263,94 & 418,97 & 377,81 & 637,60 \\
\hline 6 Material de Transporte & 113,94 & 428,71 & 796,04 & 646,24 & 1120,35 \\
\hline 7 Madeira e Mobiliário & 21,44 & 27,96 & 26,66 & 31,57 & 59,03 \\
\hline 8 Papel e Papelão & 33,83 & 139,12 & 216,26 & 185,16 & 303,02 \\
\hline 9 Borracha & 19,04 & 67,65 & 100,19 & 76,56 & 142,55 \\
\hline 10 Indústria Química & 305,77 & 379,06 & 509,63 & 463,31 & 895,94 \\
\hline 11 Indústria Farmacêutica & 2,08 & 7,02 & 12,73 & 13,55 & 28,41 \\
\hline 12 Plásticos & 12,60 & 31,40 & 53,31 & 51,15 & 89,22 \\
\hline 13 Indústria Têxtil & 9,61 & 28,73 & 135,71 & 121,35 & 194,45 \\
\hline 14 Vestuário & 1,13 & 3,43 & 12,71 & 7,91 & 18,32 \\
\hline 15 Calçados e Couros & 1,39 & 7,65 & 12,79 & 6,96 & 17,11 \\
\hline 16 Produtos Alimentares & 31,53 & 67,17 & 117,40 & 109,99 & 275,59 \\
\hline 17 Diversos & 14,68 & 45,36 & 42,98 & 35,34 & 49,91 \\
\hline 18 Serviços Industriais de U.P. & 27,35 & 70,24 & 126,47 & 91,57 & 169,33 \\
\hline 19 Construção Civil & 2,94 & 5,76 & 10,19 & 9,50 & 20,16 \\
\hline 20 Transporte e M. Comércio & 110,46 & 179,96 & 470,52 & 428,23 & 800,22 \\
\hline 21 Serviços & 56,36 & 112,59 & 267,81 & 284.08 & 511,56 \\
\hline
\end{tabular}

Tabela 5.17 - Produção Destinada as Exportações para o Paraguai - 1990 - 1994 (milhões de 1994)

\begin{tabular}{|c|c|c|c|c|c|}
\hline Setores & 1990 & 1991 & 1992 & 1993 & 1994 \\
\hline 1 Agropecuária & 27,72 & 39,90 & 48,60 & 64,18 & 147,99 \\
\hline 2 Mineração & $61(69$ & 68,55 & 77,67 & 60,59 & 91,33 \\
\hline 3 Minerais não Metálicos & 11,20 & 12,74 & 12,85 & 13,50 & 23,66 \\
\hline 4 Metalurgia & 109,36 & 132,82 & 111,11 & 128,03 & 235,80 \\
\hline 5 Mecânica e Material Elétrico & 74,10 & 87,63 & 74,39 & 85,78 & 150,68 \\
\hline 6 Material de Transporte & 62,57 & 59,94 & 37,16 & 52,49 & 110,96 \\
\hline 7 Madeira e Mobiliário & 9,74 & 4,49 & 2,96 & 3,87 & 7,64 \\
\hline 8 Papel e Papelão & 23,57 & 30,80 & 32,25 & 34,79 & 58,99 \\
\hline 9 Borracha & 32,01 & 35,13 & 31,55 & 44,37 & 91,32 \\
\hline 10 indústria Química & 91,44 & 105,91 & 107,04 & 141.79 & 257,97 \\
\hline 11 Indústria Farmacêutica & 2,19 & 15,93 & 7,63 & 10,09 & 13,60 \\
\hline 12 Plásticos & 8,23 & 9,67 & 9,31 & 11,42 & 20,17 \\
\hline 13 Indústria Têxtil & 11,10 & 11,81 & 31,75 & 42,70 & 72,57 \\
\hline 14 Vestuário & 1,64 & 2,14 & 7,36 & 7,70 & 10,36 \\
\hline 15 Calçados e Couros & 23,95 & 23,47 & 10,64 & 14,85 & 22,06 \\
\hline 16 Produtos Alimentares & 37,22 & 63,25 & 84,54 & 109,53 & 231,06 \\
\hline 17 Diversos & 9,32 & 10,83 & 8,64 & 12,17 & 18,08 \\
\hline 18 Serviços industriais de U.P. & 15,75 & 23,03 & 25,32 & 23,89 & 43,68 \\
\hline 19 Construção Civil & 1,79 & 2,00 & 2,23 & 2,63 & 5,49 \\
\hline 20 Transporte e M. Comércio & 50,83 & 57,33 & 111,10 & 134,73 & 245,27 \\
\hline 21 Serviços & 35,22 & 39,29 & 62,45 & 84,14 & 146,59 \\
\hline
\end{tabular}


Tabela 5.18 - Produção Destinada as Exportações para o Uruguai - 1990-1994 (milhões de 1994)

\begin{tabular}{|c|c|c|c|c|c|}
\hline Setores & 1990 & 1991 & 1992 & 1993 & 1994 \\
\hline 1 Agropecuária & 45,95 & 28,11 & 21,68 & 27,11 & 55,35 \\
\hline 2 Mineração & 20,35 & 11,91 & 34,41 & 102,85 & 186,09 \\
\hline 3 Minerais não Metálicos & 6,22 & 5,37 & 5,94 & 15,83 & 29,18 \\
\hline 4 Metaiurgia & 105,34 & 104,19 & 84,74 & 129,37 & 184,83 \\
\hline 5 Mecânica e Material Elétrico & 84,41 & 59,19 & 58,71 & 83,53 & 144,55 \\
\hline 6 Material de Transporte & 104,09 & 125,84 & 4,49 & 141,03 & 16234 \\
\hline 7 Madeira e Mobiliário & 26,54 & 9,84 & 4,75 & 9,39 & 16,36 \\
\hline 8 Papel e Papelão & 16,42 & 26,61 & 31,71 & 28,63 & 49,22 \\
\hline 9 Borracha & 11,27 & 13,10 & 9,93 & 14,45 & 22,37 \\
\hline 10 Indústria Química & 93,26 & 82,11 & 72,04 & 87,64 & 136,63 \\
\hline 11 Indústria Farmacêutica & 1,62 & 11,39 & 282 & 295 & $5, \pi$ \\
\hline 12 Plásticos & 10,85 & 10,16 & 9,54 & 12,10 & 19,73 \\
\hline 13 Indústria Têxtil & 6,98 & 7,29 & 27,27 & 33,52 & 43,79 \\
\hline 14 Vestuário & 0,71 & 0,73 & 2,14 & 3,74 & 4,66 \\
\hline 15 Calçados e Couros & 13,86 & 10,56 & 4,93 & 4,10 & 6,13 \\
\hline 16 Produtos Aiimentares & 12,25 & 15,15 & 17,60 & 26,07 & 49,87 \\
\hline 17 Diversos & 7,53 & 6,32 & 5,12 & 7,14 & 9,94 \\
\hline 18 Serviços Industriais de U.P. & 13,59 & 15,76 & 15,74 & 22,59 & 36,79 \\
\hline 19 Construção Civil & 1,50 & 1,34 & 1,31 & 2,52 & 4,88 \\
\hline 20 Transporte e $\mathrm{M}$. Comércio & 48,49 & 41,90 & 66,32 & 98,95 & 165,55 \\
\hline 21 Serviços & 28,84 & 25,96 & 37,14 & 73,32 & 121,51 \\
\hline
\end{tabular}

Tabela 5.19 - Produção Destinada as Exportações para o Chile - 1990-1994 (milhões de 1994)

\begin{tabular}{|c|c|c|c|c|c|}
\hline Setores & 1990 & 1991 & 1992 & 1993 & 1994 \\
\hline 1 Agropecuária & 28,46 & 34,31 & 33,89 & 25,88 & 63,56 \\
\hline 2 Mineração & 16,36 & 35,91 & 25,79 & 16,12 & 23,93 \\
\hline 3 Minerais não Metálicos & 6,24 & 12,58 & 11,76 & 10,14 & 15,42 \\
\hline 4 Metalurgia & 171,30 & 278,85 & 271,69 & 239,71 & 324,62 \\
\hline 5 Mecânica e Material Elétrico & 118,76 & 124,91 & 122,42 & 102,70 & 142,60 \\
\hline 6 Material de Transporte & 7,89 & 302,75 & 257,56 & 220,64 & 290,62 \\
\hline 7 Madeira e Mobiliiário & 8,24 & 7,08 & 5,33 & 5,26 & 7,84 \\
\hline 8 Papel e Papelão & 35,38 & 56,46 & 62,57 & 39,35 & 78,29 \\
\hline 9 Borracha & 15,13 & 29,74 & 31,52 & 29,08 & 38,09 \\
\hline 10 Indústria Química & 100,00 & 133,07 & 144,33 & 108,18 & 175,06 \\
\hline 11 Indústria Farmacêutica & 0,99 & 4,60 & 3,64 & 4,10 & 9,19 \\
\hline 12 Plásticos & 8,55 & 15,30 & 17,93 & 15,13 & 22,98 \\
\hline 13 Indústria Têxtil & 8,26 & 15,69 & 66,23 & 53,72 & 69,76 \\
\hline 14 Vestuário & 0,85 & 1,64 & 3,31 & 2,41 & 3,74 \\
\hline 15 Calçados e Couros & 1,88 & 4,44 & 7,46 & 6,51 & 12,42 \\
\hline 16 Produtos Alimentares & 15,46 & 30,57 & 33,40 & 24,60 & 65,83 \\
\hline 17 Diversos & 11,70 & 18,78 & 13,85 & 12,96 & 14,15 \\
\hline 18 Serviços Industriais de U.P. & 15,78 & 34,90 & 39,36 & 26,39 & 39,53 \\
\hline 19 Construção Civii & 1,56 & 2,86 & 3,09 & 2,55 & 4,53 \\
\hline 20 Transporte e M. Comércio & 49,55 & 81,33 & 142,23 & 117,57 & 185,72 \\
\hline 21 Serviços & 32,01 & 54,31 & 80,66 & 75,39 & 118,25 \\
\hline
\end{tabular}


Tabela 5.20 - Produção Destinada as Exportações para a Bolivia - 1990-1994 (milhões de 1994)

\begin{tabular}{|c|c|c|c|c|c|}
\hline Setores & 1990 & 1991 & 1992 & 1993 & 1994 \\
\hline 1 Agropecuária & 13,45 & 14,99 & 17,96 & 17,44 & 36,09 \\
\hline 2 Mineração & 7,74 & 9,36 & 9,75 & 10,72 & 13,92 \\
\hline 3 Minerais não Metálicos & 3,41 & 4,13 & 4,43 & 4,47 & 7,92 \\
\hline 4 Metalurgia & 68,01 & 92,49 & 92,40 & 75,32 & 132,09 \\
\hline 5 Mecânica e Material Elétrico & 50,03 & 53,89 & 53,14 & 43,92 & 69,15 \\
\hline 6 Material de Transporte & 27,33 & 40,76 & 32,95 & 25,04 & 54,47 \\
\hline 7 Madeira e Mobiliário & 9,24 & 4,24 & 2,23 & 2,34 & 4,40 \\
\hline 8 Papel e Papelão & 15,21 & 22,04 & 23,84 & 16,44 & 34,42 \\
\hline 9 Borracha & 8,31 & 9,08 & 9,83 & 10,41 & 23.35 \\
\hline 10 Indústria Química & 45,62 & 53,10 & 56,82 & 51,56 & 94,62 \\
\hline 11 Indústria Farmacêutica & 0,49 & 1,40 & 4,86 & 5,45 & 8,45 \\
\hline 12 Plásticos & 5,99 & 5,54 & 5,81 & 5,82 & 10,93 \\
\hline 13 inciústria Têxtii & 6,03 & 6,61 & 29,56 & 33,18 & 52,63 \\
\hline 14 Vestuário & 0,91 & 1,02 & 3,44 & 3,89 & 6,67 \\
\hline 15 Calcados e Couros & 32,18 & 16,31 & 7,42 & 6,32 & 11,55 \\
\hline 16 Produtos Alimentares & 15,10 & 19.48 & 25.22 & 24.90 & 4333 \\
\hline 17 Diversos & 8,51 & 9,73 & 4,85 & 5,46 & 6,95 \\
\hline 18 Serviços Industriais de U.P. & 8,06 & 11,89 & 14,16 & 10,20 & 18,37 \\
\hline 19 Construção Civil & 0,86 & 0,94 & 1,12 & 1,04 & 2,18 \\
\hline 20 Transporte e $\mathrm{M}$. Comércio & 26,93 & 28,96 & 58,44 & 55,00 & 102,47 \\
\hline 21 Servicos & 17,38 & 18,50 & 31,36 & 34,11 & 61,42 \\
\hline
\end{tabular}

Tabeia 5.21 - Produção Destinada as Exportaçōes para o Resto do Mundo - 1990-1994 (milhōes de 1994)

\begin{tabular}{|c|c|c|c|c|c|}
\hline Setores & 1990 & 1991 & 1992 & 1993 & 1994 \\
\hline 1 Agropecuária & 3176,36 & 2798,71 & 3100,10 & 2439,81 & 5808,94 \\
\hline 2 Mineração & 2004,85 & 2056,35 & 1824,54 & 1033,93 & 1737,35 \\
\hline 3 Minerais não Metálicos & 547,35 & 548,59 & 571,03 & 439,22 & 813,82 \\
\hline 4 Ñetalungia & 6784,30 & 6273,03 & 6360,53 & 4380,14 & 7810,20 \\
\hline 5 Mecânica e Material Elétrico & 2835,99 & 2548,40 & 2773,48 & 1982,59 & 3343,48 \\
\hline 6 Material de Transporte & 2543,24 & 1840,77 & 2133,51 & 1464,11 & 2723,50 \\
\hline 7 Madeira e Mobiliário & 355,83 & 407,11 & 499,49 & 534,75 & 973,44 \\
\hline 8 Papei e Papelão & 1178,88 & 1151,16 & 1140,66 & 704,71 & 1491,05 \\
\hline 9 Borracha & 467,55 & 421,76 & 473,78 & 364,05 & 650,47 \\
\hline 10 Indústria Química & 3657,38 & 2955,88 & 3461,34 & 2640,27 & 4758,80 \\
\hline 11 Indústria Famracêutica & 117,41 & 106,30 & 126,39 & 100,85 & 172,25 \\
\hline 12 Plásticos & 375,37 & 334,59 & 360,26 & 282,19 & 472,86 \\
\hline 13 Indústria Têxtil & 1287,88 & 1289,66 & 1069,04 & 617,18 & 1111,61 \\
\hline 14 Vestuário & 117,66 & 107,98 & 108,89 & 73,51 & 126,73 \\
\hline 15 Calçados e Couros & 1046,82 & 1016,18 & 1294,06 & 1003,07 & 1480,01 \\
\hline 16 Produtos Aiimentares & 4880,09 & 4729,98 & 4950,09 & 3849,97 & 8217,95 \\
\hline 17 Diversos & 416,32 & 370,59 & 398,97 & 294,26 & 524,57 \\
\hline $\begin{array}{l}18 \text { Senviços Industriais de U.P. } \\
19 \text { Construcão Civil }\end{array}$ & $\begin{array}{c}819,97 \\
86,13\end{array}$ & $\begin{array}{l}934,52 \\
74,57\end{array}$ & $\begin{array}{c}1032,97 \\
73,86\end{array}$ & $\begin{array}{c}617,10 \\
60,92\end{array}$ & $\begin{array}{c}1142,86 \\
131,13\end{array}$ \\
\hline 20 Transporie e M. Comércio & 2591,62 & 2166,66 & 2337,35 & 2894,56 & 5425,30 \\
\hline 21 Serviços & 1723,42 & 1446,21 & 1600,46 & 1805,94 & 3346,32 \\
\hline
\end{tabular}


Os produtos importados do MERCOSUL, Chile, Bolivia e Resto do Mundo não produziram alterações no processo produtivo durante o periodo analisado. Cabe verificar a evolução do valor das importações brasileiras provenientes da Argentina, Paraguai, Uruguai, Chile, Bolivia e Resto do Mundo, como função dos seguintes componentes da demanda final, isto é, consumo das familias e investimentos. Particularmente, no que tange ao valor das importações da Ârgentina destinadas à formação bruta de capital, deve-se observar a elevação do investimento do setor 6 Material de Transporte.

Quanto ao consumo das familias, os dados revelam crescimento em relação a alguns setores: 6 - Material de Transporte, 9 - Borracha, 13 - Indústria Têxtil e 15 Calçados e Couros, apenas considerando a participação dos produtos importados da Argentina. Vale salientar a elevação apresentada no setor 6 - Material de Transporte e no setor 12 - Plásticos.

Em relação ao valor das importações provenientes dos outros paises do MERCOSUL, ou seja, Paraguai e Uruguai, Chile e Bolivia, os resultados se apresentaram relativamente constantes no periodo analisado (tabelas 5.22 e 5.23).

A importância dos fatores macroeconômicos para se explicar o intercâmbio comercial entre o Brasil e a Árgentina, principal parceiro no MERCOSUL, não pode ser ignorada. Ao final de 1993, o Brasil apresentava um superávit na balança comercial com a Ärgentina de US $\$ 941$ milhões e, em 1994, esse valor cai para US $\$ 473$ milhões. Esse declinio deveu-se à recuperação do crescimento econômico brasileiro, entre outros fatores.

O que os dados revelam é que os saldos comerciais de um pais são determinados pelo rítmo da atividade econômica, pela taxa de câmbio e pelo grau de abertura da economia. Simetrias nas taxas de crescimento e de câmbio explicam os resultados. $O$ indice da taxa de câmbio real entre a moeda do Brasil e a da Argentina atingiu 155,61 em dezembro de 1993 (Pereira, 1996). 
Tabela 5.22 - Participação (\%) dos Produtos Importados em Relação ao Consumo das Farrilias (F) 1990-1994

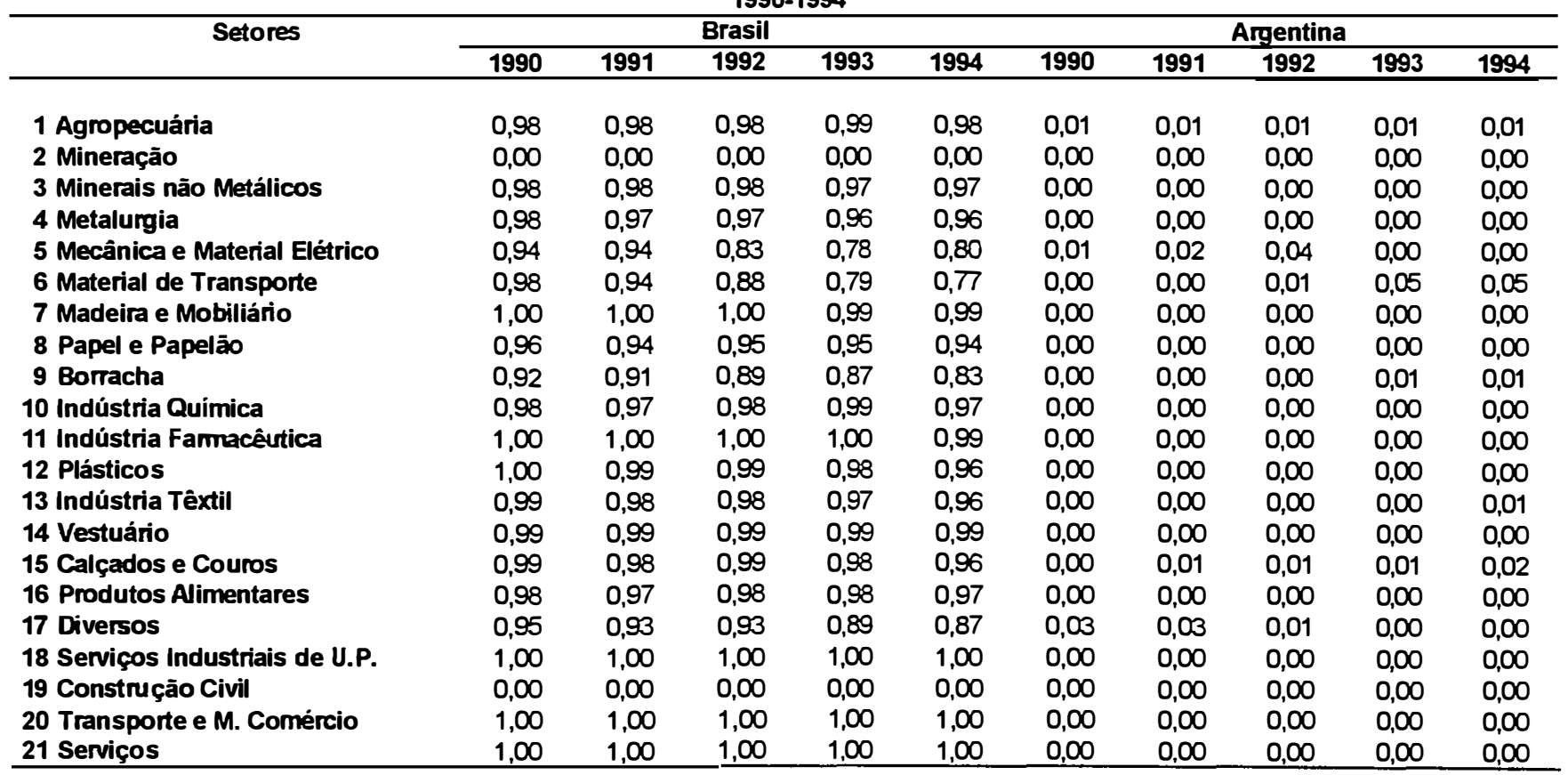

Tabela 5.23 - Participação (\%) dos Produtos Importados em Relação à Formação Bruta de Capital (K)

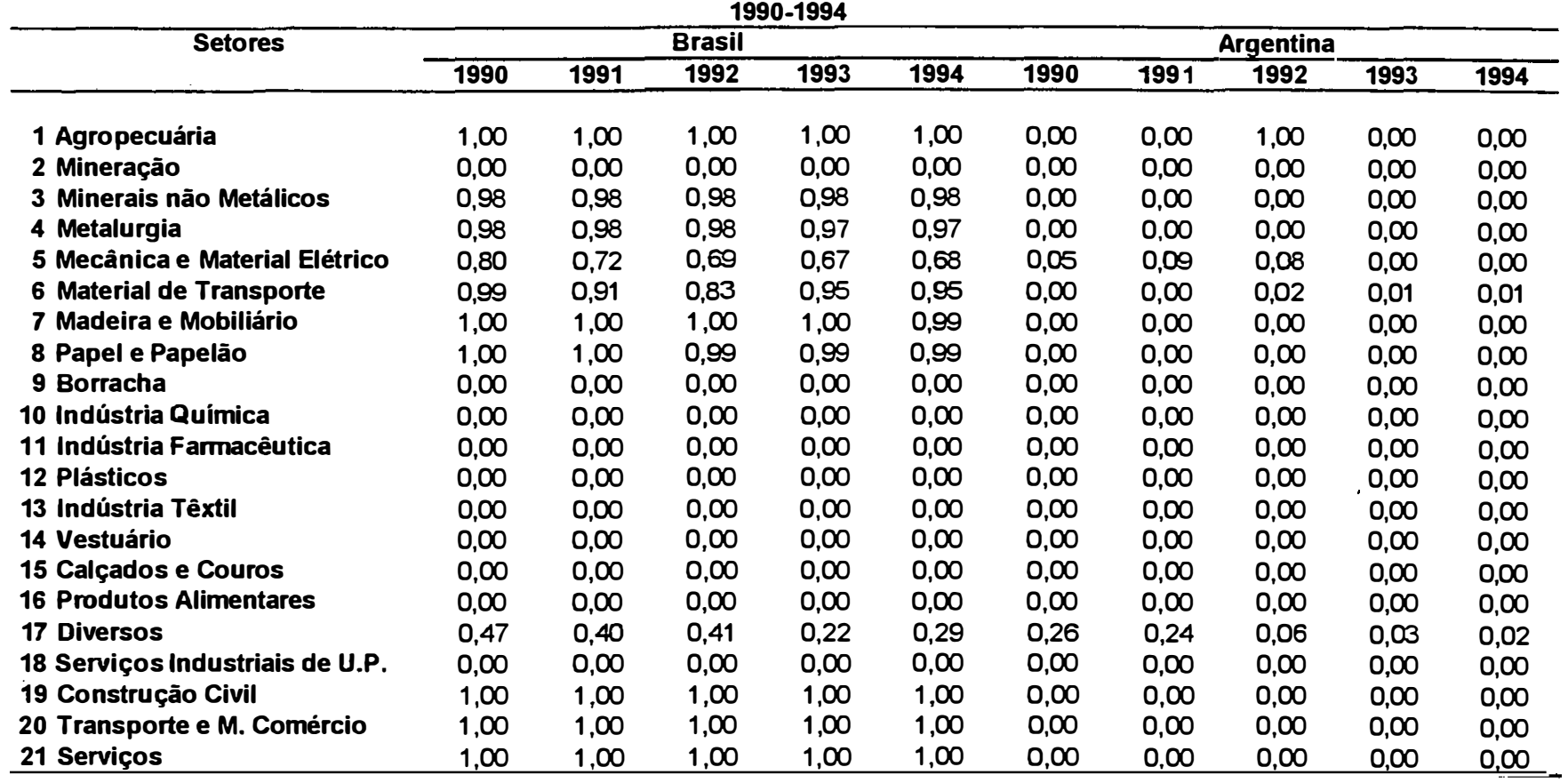




\section{3 Índices de ligações interindustriais}

A análise dos resultados obtidos através dos enfoques de setores-chave, ligações interindustriais e campo de influência foi realizada, procurando avaliar o comportamento dos vinte e um setores analisados ao longo do período 1990-1994. Foram utilizadas as matrizes de insumo-produto para o Brasil, construídas para 1990, 1991, 1992, 1993 e 1994. Os indices obtidos são apresentados nas tabelas 5.24 a 5.30, e, nos Gráficos 5.1 a 5.35, assim como a ordem de cada setor para um dado indice num dado ano.

\subsection{1 Índices de ligações para trás}

Os índices de ligações para trás, de Rasmussen (1956) e Hirschman (1958), para a economia brasileira em diferentes períodos são apresentados na Tabela $5.24 \mathrm{e}$ os respectivos índices de dispersão são apresentados na Tabela 5.26. Esses indices procuram avaliar a importância dos diferentes setores como demandantes de insumos dos demais setores da economia. Os resultados mostram que os setores 3 - Minerais não Mietálicos; 4 - Mietalurgia; 6 - Material de Transporte; 7 - Madeira e Miobiliário; 8 Papel e papelão; 9 - Borracha; 13 - Indústria Têxtil; 14 - Vestuário; 15 - Calçados e Couros e 16 - Produtos Alimentares, apresentam índices maiores do que 1, para o período 1990-1994, significando que são setores altamente dependentes do resto da economia (Tabela 5.24). Dentre esses setores, o setor 6 - Material de Transporte apresenta o maior valor desse índice apenas em 1990. Já o setor 13 - Indústria Têxtil apresenta o maior valor desse índice apenas em 1991. O setor 15 - Calçados e Couros apresenta o maior valor desse índice nos anos de 1992 e 1993. Em 1994, o setor 4 Mietalurgia apresenta o maior valor desse indice. 
Por sua vez os coeficientes de dispersão dos índices de ligação para trás mostram-se mais elevados para os segmentos do agregado serviços, ou seja: 18 Serviços Industriais de Utilidade Pública; 20 - Transporte e Margem de Comércio e 21 - Serviços. Os setores 1 - Agropecuária, 4 - Metalurgia e 13 - Indústria Têxtil apresentam, também, valores relativamente altos de dispersão para o período analisado. Assim, um impacto de uma variação na produção nestes setores estimularia os demais de maneira desigual se concentrando em poucos setores. 
Tabela 5.24 - Indice de ligaçōes para trás de Rasmussen/Hirschman - Brasil: 1990-1994.

\begin{tabular}{|c|c|c|c|c|c|c|c|c|c|c|}
\hline \multirow[t]{2}{*}{ Setores } & \multicolumn{2}{|c|}{1990} & \multicolumn{2}{|c|}{1991} & \multicolumn{2}{|c|}{1992} & \multicolumn{2}{|c|}{1993} & \multicolumn{2}{|l|}{1994} \\
\hline & Indice & Ordem & Indice & Ordem & Índice & Ordem & Índice & Ordem & Indice & Ordem \\
\hline 1 Agropecuária & 0,8363 & 17 & 0,8539 & 19 & 0,8752 & 18 & 0,873 & 19 & 0,8239 & 19 \\
\hline 2 Mineração & 0,886 & 16 & 0,8795 & 17 & 0,9036 & 16 & 0,9809 & 11 & 0,9978 & 12 \\
\hline 3 Minerais não Metálicos & 1,0229 & 10 & 1,0032 & 12 & 1,022 & 10 & 1,0314 & 10 & 1,0089 & 11 \\
\hline 4 Metalurgia & 1,1977 & 2 & 1,1548 & 4 & 1,1898 & 2 & 1,2032 & 2 & 1,1961 & 1 \\
\hline 5 Mecānica e Material Elétrico & 1,0194 & 11 & 0,9831 & 14 & 0,9586 & 13 & 0,9385 & 14 & 0,9456 & 14 \\
\hline 6 Material de Transporte & 1,2103 & 1 & 1,1743 & 3 & 1,1686 & 5 & 1,1628 & 5 & 1,1619 & 3 \\
\hline 7 Madeira e Mobiliário & 1,0464 & 9 & 1,0181 & 9 & 1,0595 & 9 & 1,0349 & 9 & 1,024 & 9 \\
\hline 8 Papel e Papelão & 1,1072 & 6 & 1,0677 & 8 & 1,1293 & 7 & 1,1694 & 4 & 1,1572 & 4 \\
\hline 9 Borracha & 1,103 & 8 & 1,0953 & 7 & 1,099 & 8 & 1,1039 & 8 & 1,106 & 7 \\
\hline 10 Indústria Quimica & 0,9803 & 12 & 1,0044 & 11 & 0,9712 & 12 & 0,8993 & 16 & 0,9422 & 15 \\
\hline 11 Indústria Farmacêutica & 0,9448 & 14 & 0,9873 & 13 & 0,9189 & 15 & 0,9005 & 15 & 0,8992 & 16 \\
\hline 12 Plásticos & 0,9751 & 13 & 1,0104 & 10 & 1,0137 & 11 & 0,9792 & 12 & 1,0092 & 10 \\
\hline 13 Indústria Têxtil & 1,1323 & 5 & 1,1798 & 1 & 1,1826 & 3 & 1,1156 & 7 & 1,1547 & 5 \\
\hline 14 Vestuário & 1,1031 & 7 & 1,1495 & 5 & 1,1401 & 6 & 1,1234 & 6 & 1,1282 & 6 \\
\hline 15 Calçados e Couros & 1,1656 & 4 & 1,1304 & 6 & 1,56 & 1 & 1,096 & 1 & 1,1049 & 8 \\
\hline 16 Produtos Alimentares & $1,17 \approx 3$ & 3 & 1,1774 & 2 & 1,1764 & 4 & 1,1892 & 3 & 1,1778 & 2 \\
\hline 17 Diversos & 0,9302 & 15 & 0,9236 & 15 & 0,9266 & 14 & 0,9632 & 13 & 0,9635 & 13 \\
\hline 18 Serviços Industriais de U.P. & 0,8317 & 18 & 0,8657 & 18 & 0,863 & 19 & 0,8854 & 17 & 0,8535 & 17 \\
\hline 19 Construção Civil & 0,8945 & 19 & 0,904 & 16 & 0,8913 & 17 & 0,8785 & 18 & 0,8415 & 18 \\
\hline 20 Transporte e M. Comércio & 0,7809 & 20 & 0,7732 & 20 & 0,8066 & 20 & 0,8385 & 20 & 0,8113 & 20 \\
\hline 21 Serviços & 0,6561 & 21 & 0,6644 & 21 & 0,648 & 21 & 0,6596 & 21 & $0, \circlearrowleft 26$ & 21 \\
\hline
\end{tabular}

Tabela 5.25 - Indice de ligaçōes para frente de Rasmussen/Hirschman - Brasil: 1990-1994

\begin{tabular}{|c|c|c|c|c|c|c|c|c|c|c|}
\hline \multirow[t]{2}{*}{ Setores } & \multicolumn{2}{|c|}{1990} & \multicolumn{2}{|c|}{1991} & \multicolumn{2}{|c|}{1992} & \multicolumn{2}{|c|}{1993} & \multicolumn{2}{|c|}{1994} \\
\hline & Índice & Ordem & Índice & Ordem & Índice & Ordem & Índice & Ordern & índice & Ordem \\
\hline 1 Agropecuária & 1,2229 & 6 & 1,2624 & 6 & 1,2562 & 5 & 1,2593 & 5 & 1,3968 & 5 \\
\hline 2 Mineraçāo & 0,853 & 10 & 0,8346 & 11 & 0,8245 & 11 & 0,7817 & 13 & 0,7811 & 13 \\
\hline 3 Minerais não Metálicos & 0,7839 & 13 & 0,7981 & 12 & 0,7849 & 12 & 0,7868 & 12 & 0,7975 & 12 \\
\hline 4 Metalurgia & 1,6871 & 3 & 1,6258 & 3 & 1,6485 & 3 & 1,6188 & 3 & 1,6171 & 3 \\
\hline 5 Mecânica e Material Elétrico & 1,1206 & 7 & 1,0528 & 8 & 1,1009 & 8 & 1,0929 & 8 & 1,0238 & 8 \\
\hline 6 Material de Transporte & 0,7612 & 14 & 0,7386 & 14 & 0,7383 & 14 & 0,7304 & 14 & 0,7296 & 14 \\
\hline 7 Madeira e Mobiliário & 0,6454 & 16 & 0,6434 & 16 & 0,6307 & 17 & 0,64 & 16 & 0,6462 & 16 \\
\hline 8 Papel e Papelão & 0,9234 & 9 & 0,9658 & 9 & 0,9182 & 9 & 0,8886 & 9 & 0,8856 & 9 \\
\hline 9 Borracha & 0,7862 & 12 & 0,7854 & 13 & 0,7837 & 13 & 0,8008 & 11 & 0,8043 & 11 \\
\hline 10 Indústria Química & 2,1986 & 1 & 2,2076 & 1 & $2,2 \Subset 33$ & 1 & 2,2039 & 1 & 2,206 & 1 \\
\hline 11 Indústria Farmacêutica & 0,5088 & 20 & 0,5091 & 20 & 0,5185 & 20 & 0,5258 & 20 & $0,51 \varpi$ & 20 \\
\hline 12 Plásticos & 0,7084 & 15 & 0,7108 & 15 & 0,6931 & 15 & 0,7015 & 15 & 0,6919 & 15 \\
\hline 13 Indústria Têxtil & 1,2797 & 5 & 1,2932 & 5 & 1,244 & 6 & 1,229 & 6 & 1,2283 & 6 \\
\hline 14 Vestuário & 0,4962 & 21 & 0,5074 & 21 & 0,5053 & 21 & 0,5087 & 21 & 0,5087 & 21 \\
\hline 15 Calçados e Couros & 0,616 & 18 & 0,6088 & 18 & 0,5793 & 18 & 0,5858 & 18 & 0,6032 & 18 \\
\hline 16 Produtos Alimentares & 0,8398 & 11 & 0,8792 & 10 & 0,8676 & 10 & 0,8522 & 10 & 0,8609 & 10 \\
\hline 17 Diversos & 0,6369 & 17 & 0,6391 & 17 & 0,6336 & 16 & 0,6159 & 17 & 0,6127 & 17 \\
\hline 18 Serviços Industriais de U.P. & 1,0276 & 8 & 1,0928 & 7 & 1,1399 & 7 & 1,1581 & 7 & 1,1481 & 7 \\
\hline 19 Construção Civil & 0,5573 & 19 & 0,5675 & 19 & 0,5613 & 19 & 0,568 & 19 & 0,5766 & 19 \\
\hline 20 Transporte e M. Comércio & 1,8469 & 2 & 1,7872 & 2 & 1,778 & 2 & 1,8771 & 2 & 1,7923 & 2 \\
\hline 21 Serviços & 1,5001 & 4 & 1,4904 & 4 & 1,53 & 4 & 1,5747 & 4 & 1,5663 & 4 \\
\hline
\end{tabular}


Tabela 5.26 - Dispersão do indice de ligaçōes para trás de Rasmussen/Hirschman - Brasil: 1990-1994

\begin{tabular}{|c|c|c|c|c|c|}
\hline Setores & 1990 & 1991 & 1992 & 1993 & 1994 \\
\hline 1 Agropecuária & 3,1117 & 3,1445 & 3,099 & 3,1682 & 3,3551 \\
\hline 2 Mineração & 2,5541 & 2,6404 & 2,5748 & 2,4386 & 2,4154 \\
\hline 3 Minerais não Metálicos & 2,6527 & 2,7539 & 2,6939 & 2,7286 & 2,8094 \\
\hline 4 Metalurgia & 3,0287 & 3,0985 & 3,0794 & 3,1366 & 3,1424 \\
\hline 5 Mecânica e Material Elétrico & 2,7114 & 2,7384 & 2,7818 & 2,8149 & 2,7761 \\
\hline 6 Material de Transporte & 2,4766 & 2,5263 & 2,516 & 2,5718 & 2,5828 \\
\hline 7 Madeira e Mobiliário & 2,4599 & 2,5399 & 2,425 & 2,5319 & 2,5739 \\
\hline 8 Papel e Papelão & 2,6738 & 2,8365 & 2,6759 & 2,6299 & 2,642 \\
\hline 9 Borracha & 2,6562 & 2,6963 & 2,6889 & 2,7563 & 2,7578 \\
\hline 10 Indústria Quimica & 2,924 & 2,9499 & 2,9868 & 3,1646 & 3,1167 \\
\hline 11 Indústria Farmacèutica & 2,3484 & 2,2635 & 2,4569 & 2,5601 & 2,5263 \\
\hline 12 Plásticos & 2,4804 & 2,4638 & 2,4504 & 2,5705 & 2,5217 \\
\hline 13 Indústria Têxtil & 3,0366 & 2,9759 & 2,9054 & 3,0382 & 2,9685 \\
\hline 14 Vestuário & 2,3078 & 2,2777 & 2,2568 & 2,3468 & 2,326 \\
\hline 15 Calçados e Couros & 2,2825 & 2,3318 & 2,3842 & 2,4019 & 2,3912 \\
\hline 16 Produtos Alimentares & 2,4066 & 2,4746 & 2,4667 & 2,4984 & 2,5453 \\
\hline 17 Diversos & 2,3748 & 2,4472 & 2,4355 & 2,5067 & 2,5016 \\
\hline 18 Serviços Industriais de U.P. & 3,3759 & 3,0972 & 3,1628 & 3,7095 & 3,7715 \\
\hline 19 Construção Civil & 2,5283 & 2,5605 & 2,5809 & 2,6674 & 2,7908 \\
\hline 20 Transporte e M. Comércio & 3,1238 & 3,1826 & 3,0756 & 3,0779 & 3,133 \\
\hline 21 Serviços & 3,6933 & 3,7354 & 3,7852 & 3,8092 & 3,7049 \\
\hline
\end{tabular}

Tabela 5.27 -Dispersão do indice de ligaçōes para frente de Rasmussen/Hirschman - Brasil: 1990-94

\begin{tabular}{|c|c|c|c|c|c|}
\hline Setores & 1990 & 1991 & 1992 & 1993 & 1994 \\
\hline 1 Agropecuária & 2,2041 & 2,199 & 2,2256 & 2,2832 & 2,0687 \\
\hline 2 Mineração & 2,6208 & 2,7581 & 2,7929 & 3,018 & 3,049 \\
\hline 3 Minerais não Metálicos & 3,4862 & 3,4906 & 3,5356 & 3,5997 & 3,5739 \\
\hline 4 Metalurgia & 2,1481 & 2,1954 & 2,2135 & 2,3298 & 2,3267 \\
\hline 5 Mecánica e Material Elétrico & 2,3757 & 2,4731 & 2,3342 & 2,3299 & 2,4779 \\
\hline 6 Material de Transporte & 3,8947 & 3,9892 & 3,9495 & 4,0578 & 4,0765 \\
\hline 7 Madeira e Mobiliário & 4,0294 & 4,0668 & 4,1175 & 4,1289 & 4,0969 \\
\hline 8 Papel e Papelão & 3,1897 & 3,1184 & 3,2801 & 3,4461 & 3,4402 \\
\hline 9 Borracha & 3,7196 & 3,7526 & 3,7587 & 3,7878 & 3,783 \\
\hline 10 Indústria Química & 1,2238 & 1,2715 & 1,2093 & 1,2166 & 1,2664 \\
\hline 11 Indústria Farmacêutica & 4,4001 & 4,4271 & 4,4058 & 4,4301 & 4,4428 \\
\hline 12 Plásticos & 3,258 & 3,3268 & 3,3916 & 3,4109 & 3,4687 \\
\hline 13 Indústria Têxtil & 2,875 & 2,9152 & 2,954 & 2,9673 & 2,9909 \\
\hline 14 Vestuário & 4,434 & 4,4504 & 4,4566 & 4,5069 & 4,514 \\
\hline 15 Calçados e Couros & 4,4254 & 4,4354 & 4,4502 & 4,4795 & 4,4734 \\
\hline 16 Produtos Alimentares & 3,2042 & 3,1479 & 3,1856 & 3,3052 & 3,239 \\
\hline 17 Diversos & 3,4898 & 3,5637 & 3,5846 & 3,955 & 3,9761 \\
\hline 18 Serviços Industriais de U.P. & 2,6735 & 2,3764 & 2,3168 & 2,7778 & 2,7426 \\
\hline 19 Construção Civil & 4,107 & 4,1253 & 4,1464 & 4,175 & 4,1177 \\
\hline 20 Transporte e M. Comércio & 1,184 & 1,2418 & 1,2591 & 1,2351 & 1,2835 \\
\hline 21 Serviços & 1,5021 & 1,5559 & 1,4897 & 1,4898 & 1,5367 \\
\hline
\end{tabular}




\subsection{2 Índices de ligações para frente}

Os indices de ligações para frente de Rasmussen (1956) e Hirschman (1958) são apresentados na Tabela 5.25 e os respectivos índices de dispersão na Tabela 5.27. Segundo Rasmussen (1956) e Hirschman (1958), esses índices procuram medir a importância de determinados setores no fornecimento de insumos aos demais setores da economia (Guilhoto \& Picerno, 1995).

Considerando somente os cinco setores com maior índice vê-se que no período analisado os setores 10 - Indústria Química; 20 - Transporte e M. Comércio; 4 Metalurgia; e 21 - Serviços apresentam maiores índices de ligação para frente, respectivamente. Ocupando o quinto lugar, nos anos de 1991 e 1992 aparecem os setores 13 - Indústria Têxtil, sendo substituído pelo setor 1 - Agropecuário nos anos de 1992, 1993 e 1994.

Com relação aos coeficientes de dispersão dos índices de ligação para frente, observa-se que os setores 10 - Indústria Química, 20 - Transporte e Margem de Comércio e 21 - Serviços apresentam valores relativamente baixos de dispersão, significando que a demanda por estes setores ocorre de maneira uniforme.

\subsection{3 Índices puros de ligações}

Os índices puros de ligações para trás e para frente são apresentados nas Tabela 5.28 e 5.29. Do mesmo modo que os índices de ligações para trás, revelam melhor as diferenças entre os setores, por considerarem o nivel de produção e a estrutura interna da economia. Neste caso, os índices de ligações para trás e para 
frente são somados, gerando o indice total de ligações onde a agregação possibilita uma nova base para determinação de setores-chave na economia.

Os resultados obtidos para os indices puros de ligações para trás ( $P B L$ ), revelam os seguintes setores com maiores impactos na demanda de insumos de cada setor realizado pelo próprio setor na economia, em ordem decrescente, para o ano de 1990: 16 - Produtos Alimentares; 19 - Construção Civil; 21 - Serviços; 20 - Transporte e M. Comércio e 5 - Mecânica e Material Elétrico. Esses resultados praticamente não se alteraram após a criação do MERCOSUL.

Os resultados obtidos para os indices puros de ligações para frente (PFL), revelam os setores com maior impacto da produção total no resto da economia, em ordem decrescente, para o ano de 1990: 10 - Indústria Quimica; 20 - Transporte e M. Comércio; 1 - Agropecuária; 4 - Metalurgia e 21 - Serviços. A partir de 1991, verifica-se que não há mudanças significativas, a não ser, no ano de 1994, onde o setor 1 Agropecuária que ocupa nos anos analisados a terceira ordem, passa a ocupar a primeira ordem e o setor 20 - Transporte e M. Comércio passa a ocupar a terceira ordem. Os resultados obtidos para os indices puros totais de ligação são apresentados mais adiante, quando analisa-se os Setores-chave. 
Tabela 5.28 - Indice puro de ligaçōes para trás - Brasil - 1990-94

\begin{tabular}{|c|c|c|c|c|c|c|c|c|c|c|}
\hline \multirow[t]{2}{*}{ Setores } & \multicolumn{2}{|c|}{1990} & \multicolumn{2}{|c|}{1991} & \multicolumn{2}{|c|}{1992} & \multicolumn{2}{|c|}{1993} & \multicolumn{2}{|c|}{1994} \\
\hline & Indice & Ordem & Indice & Ordem & Indice & Ordem & Indlce & Ordem & Indice & Ordem \\
\hline 1 Agropecuária & 670.435 & 9 & 3.109 .948 & 9 & 35.813 .047 & 9 & 642.199 & 9 & 6.308 .141 & 8 \\
\hline 2 Mineraçăo & 146.710 & 18 & 837.732 & 18 & 9.739 .114 & 18 & 180.133 & 18 & 1.426 .767 & 18 \\
\hline 3 Minerais năo Metálicos & 59.819 & 19 & 325.657 & 19 & 3.568.๘6 & 19 & 74.489 & 19 & 512.879 & 19 \\
\hline 4 Metalurgia & 345.936 & 13 & 1.981 .670 & 11 & 25.122 .387 & 10 & 481.953 & 11 & 3.875 .364 & 11 \\
\hline 5 Mecánica e Material Elétrico & 1.246 .938 & 5 & 5.088 .095 & 5 & 50.046 .674 & 6 & 1.174 .216 & 6 & 12.110 .290 & 6 \\
\hline 6 Material de Transporte & 1.059 .864 & 6 & 4.745 .902 & 6 & 51.938 .246 & 5 & 1.330 .831 & 5 & 12.279 .010 & 5 \\
\hline 7 Madeira e Mobiliário & 379.828 & 11 & 1.530 .721 & 14 & 17.209 .921 & 13 & 406.604 & 12 & 3.423 .403 & 12 \\
\hline 8 Papel e Papetăo & 254.492 & 14 & 1.144 .657 & 17 & 13.285 .628 & 16 & 308.761 & 14 & 2.673 .033 & 17 \\
\hline 9 Borracha & 24.939 & 21 & 150.143 & 21 & 1.841 .886 & 21 & 47.195 & 21 & 432.759 & 20 \\
\hline 10 Indústria Química & 683.076 & 8 & 3.797 .296 & 7 & 44.039 .083 & 7 & 954.889 & 7 & 7.231 .519 & 7 \\
\hline 11 Indústria Farmacéutica & 427.096 & 10 & 2.131 .551 & 10 & 22.358 .685 & 11 & 504.956 & 10 & 4.238 .990 & 10 \\
\hline 12 Plásticos & 37.276 & 20 & 224.562 & 20 & 2.152 .378 & 20 & 52.252 & 20 & 429.578 & 21 \\
\hline 13 Indústria Têxtil & 233.680 & 16 & $1.215 . \widetilde{6} 6$ & 16 & 13.153 .918 & 17 & 243.855 & 15 & 2.183 .223 & 15 \\
\hline 14 Vestuário & 917.767 & 7 & 3.758 .114 & 8 & 36.644 .757 & 8 & 763.271 & 8 & 6.279 .945 & 9 \\
\hline 15 Calçados e Couros & 361.909 & 12 & 1.555 .973 & 13 & 16.587 .377 & 14 & 388.739 & 13 & 2.829 .851 & 13 \\
\hline 16 Produtos Alimentares & 3.569 .372 & 1 & 17.928.191 & 1 & 202.969 .208 & 1 & 4.497 .544 & 1 & 40.565 .920 & 1 \\
\hline 17 Diversos & 234.207 & 15 & 1.224 .980 & 15 & 13.740 .370 & 15 & 223.121 & 17 & 1.955 .650 & 16 \\
\hline 18 Serviços Industriais de U.P. & 208.583 & 17 & 1.592 .061 & 12 & 18.272 .034 & 12 & 240.393 & 16 & 1.753 .468 & 17 \\
\hline 19 Construçăo Civil & 3.430 .480 & 2 & 15.662 .928 & 3 & 166.610 .158 & 3 & 3.614 .879 & 2 & 29.971 .226 & 3 \\
\hline 20 Transporte e M. Comércio & 1.712 .384 & 4 & 7.331 .401 & 4 & 79.624 .696 & 4 & 2.015 .908 & 4 & 16.650 .667 & 4 \\
\hline 21 Serviços & 2.978 .389 & 3 & 16.582 .384 & 2 & 153.948 .064 & 2 & 3.191.231 & 3 & 33.249 .888 & 2 \\
\hline
\end{tabular}

Tabela 5.29 - Indice puro de ligaçỏes para frente - Brasil - 199094

\begin{tabular}{|c|c|c|c|c|c|c|c|c|c|c|}
\hline \multirow[t]{2}{*}{ Setores } & \multicolumn{2}{|c|}{1990} & \multicolumn{2}{|c|}{1991} & \multicolumn{2}{|c|}{1992} & \multicolumn{2}{|c|}{1993} & \multicolumn{2}{|c|}{1994} \\
\hline & indice & Ordem & indice & Ordem & indice & Ordem & Indice & Ordem & índice & Ordem \\
\hline 1 Agropecuária & 2.148 .013 & 3 & 11.330 .875 & 3 & 121.650 .685 & 3 & 2.806 .500 & 3 & 28.721 .070 & 1 \\
\hline 2 Mineraçào & 626.760 & 11 & 285.561 & 19 & 30.586 .010 & 12 & 580.094 & 12 & 4.736 .343 & 12 \\
\hline 3 Minerais năo Metálicos & 798.786 & 9 & 3.969 .636 & 8 & 40.795 .401 & 8 & 865.728 & 8 & 7.856 .578 & 8 \\
\hline 4 Metalurgia & 2.098 .636 & 4 & 9.573 .834 & 4 & 101.695 .385 & 4 & 2.240 .351 & 4 & 20.495 .284 & 4 \\
\hline 5 Mecanica e Material Elétrico & 1.011 .195 & 6 & 4.510233 & 7 & 52.989 .590 & 7 & 1.146 .334 & 6 & 8.805 .784 & 7 \\
\hline 6 Material de Transporte & 385.329 & 14 & 1.609 .955 & 13 & 17.558.592 & 14 & 337.390 & 14 & 3.171 .469 & 14 \\
\hline 7 Madeira e Mobiliário & 254.765 & 17 & 1.156 .031 & 17 & 10.783 .070 & 18 & 243.265 & 16 & 2.337 .851 & 17 \\
\hline 8 Papel e Papelăo & 693.227 & 10 & 3.861 .174 & 9 & 34.706 .085 & 9 & 661.819 & 11 & 6.134 .897 & 10 \\
\hline 9 Borracha & 300.477 & 15 & 1.434 .667 & 14 & 15.193.797 & 15 & 329.896 & 15 & 2.949 .128 & 15 \\
\hline 10 Indústria Química & 2.752 .631 & 1 & 12.926 .026 & 2 & 144.276 .483 & 1 & 3.239 .741 & 1 & 27.409 .280 & 2 \\
\hline 11 Indústria Farmacéutica & 78.779 & 19 & 326.130 & 18 & 4.079 .868 & 19 & 85.806 & 19 & 656.150 & 19 \\
\hline 12 Plásticos & 437.433 & 13 & 2.006 .316 & 12 & 19.788.075 & 13 & 441.866 & 13 & 3.629 .991 & 13 \\
\hline 13 Indústria Têxtil & 800.856 & 8 & 3.432 .581 & 10 & 32.592 .436 & 11 & 689.047 & 9 & 5.781 .450 & 11 \\
\hline 14 Vestuário & 26.729 & 21 & 122.579 & 21 & 1.239293 & 21 & 16.206 & 21 & 127.810 & 21 \\
\hline 15 Calçados e Couros & 34.828 & 20 & 153.431 & 20 & 1.360 .795 & 20 & 22.821 & 20 & 215.901 & 20 \\
\hline 16 Produtos Alimentares & 581.327 & 12 & 3.305 .631 & 11 & 33.137 .261 & 10 & 679.497 & 10 & 6.886 .470 & 9 \\
\hline 17 Diversos & 265.755 & 16 & 1.261 .705 & 15 & 13.012 .116 & 16 & 239.306 & 17 & 2.136 .554 & 18 \\
\hline 18 Serviços Industriais de U.P. & 856.095 & 7 & 5.098 .124 & 6 & 56.888 .448 & 6 & 1.054 .505 & 7 & 9.617 .801 & 6 \\
\hline 19 Construçāo Civil & 228.940 & 18 & 1.169 .960 & 16 & 10.984 .016 & 17 & 230.409 & 18 & 2.555 .936 & 16 \\
\hline 20 Transporte e M. Comércio & 2.707 .484 & 2 & 13.035.931 & 1 & 135.897 .784 & 2 & 3.136 .711 & 2 & 26.754 .537 & 3 \\
\hline 21 Serviços & 1.768 .160 & 5 & 8.251 .766 & 5 & 93.600 .200 & 5 & 2.168 .534 & 5 & 18.381.953 & 5 \\
\hline
\end{tabular}


Tabela 5.30 - Indice puro total de ligaçỏes - Brasil - 199094

\begin{tabular}{|c|c|c|c|c|c|c|c|c|c|c|}
\hline \multirow[t]{2}{*}{ Setores } & \multicolumn{2}{|c|}{1990} & \multicolumn{2}{|c|}{1991} & \multicolumn{2}{|c|}{1992} & \multicolumn{2}{|c|}{1903} & \multicolumn{2}{|c|}{1994} \\
\hline & indice & Ordem & Indice & Ordem & indice & Ordem & Índice & Ondern & indice & Ordem \\
\hline 1 Agropecuária & 2.818 .448 & 6 & 14.440 .823 & 6 & 157.463 .732 & 6 & 3.448.699 & 6 & 35.029 .211 & 4 \\
\hline 2 Mineraçăo & 773.470 & 15 & 3.693 .294 & 15 & 40.325 .124 & 14 & 760.227 & 15 & 6.163 .109 & 15 \\
\hline 3 Minerais não Metálicos & 858.604 & 14 & 4.295 .293 & 13 & 44.364 .037 & 13 & 940.217 & 12 & 8.369.456 & 12 \\
\hline 4 Metalurgia & 2.444 .572 & 7 & 11.555 .504 & 7 & 126.817.772 & 7 & 2.722 .304 & 7 & 24.370 .648 & 7 \\
\hline 5 Mecánica e Material Elétrico & 2.258 .133 & 8 & 9.598 .328 & 8 & 103.036.264 & 8 & 2.320 .550 & 8 & 20.916.074 & 8 \\
\hline 6 Material de Transporte & 1.445 .193 & 9 & 6.355 .857 & 10 & 69.496 .838 & 10 & 1.668 .220 & 9 & 15.450 .478 & 9 \\
\hline 7 Madeira e Mobiliário & 634.593 & 16 & 2.686 .752 & 16 & 27.992.991 & 16 & 649.869 & 16 & 5.761 .254 & 16 \\
\hline 8 Papel e Papelâo & 947.718 & 12 & 5.005 .831 & 11 & 47.991 .713 & 11 & 970.580 & 11 & 8.807 .930 & 11 \\
\hline 9 Borracha & 325.416 & 21 & 1.584 .810 & 21 & 17.035 .683 & 21 & 377.091 & 21 & 3.381 .887 & 20 \\
\hline 10 Indústria Quimica & 3.435.707 & 5 & 16.723 .322 & 5 & 188.315 .566 & 4 & 4.194.630 & 4 & 34.640 .799 & 5 \\
\hline 11 Indústria Farmacéutica & 505.874 & 17 & 2.457 .681 & 18 & 26.438 .554 & 18 & 590.761 & 17 & 4.895 .140 & 17 \\
\hline 12 Plásticos & 474.709 & 19 & 2.230 .878 & 19 & 21.940 .453 & 19 & 494.118 & 18 & 4.059 .569 & 18 \\
\hline 13 Indústria Téxtil & 1.034 .536 & 11 & 4.648 .217 & 12 & 45.746 .354 & 12 & 932.902 & 13 & 7.964 .674 & 13 \\
\hline 14 Vestuário & 944.496 & 13 & 3.880 .693 & 14 & 37.884 .050 & 15 & 779.477 & 14 & 6.407 .754 & 14 \\
\hline 15 Calçados e Couros & 396.737 & 20 & 1.709 .405 & 20 & 17.948.172 & 20 & 411.560 & 20 & 3.045 .752 & 21 \\
\hline 16 Produtos Alimentores & 4.150 .699 & 3 & 21.233 .821 & 2 & 236.106 .469 & 2 & 5.177 .040 & 2 & 47.452 .391 & 2 \\
\hline 17 Diversos & 499.962 & 18 & 2.486 .685 & 17 & 26.752 .486 & 17 & 462.427 & 19 & 4.092 .203 & 19 \\
\hline 18 Serviços Industriais de U.P. & 1.064 .678 & 10 & 6.690 .185 & 9 & 75.160 .482 & 9 & 1.294.899 & 10 & 11.371 .268 & 10 \\
\hline 19 Construçăo Civil & 3.659 .420 & 4 & 16.832 .888 & 4 & 177.594.174 & 5 & 3.845 .288 & 5 & 32.527 .162 & 6 \\
\hline 20 Transporte e M. Comércio & 4.419 .868 & 2 & 20.367.332 & 3 & 215.522 .480 & 3 & 5.152 .619 & 3 & 43.405 .203 & 3 \\
\hline 21 Serviços & 4.746 .549 & 1 & 24.834 .150 & 1 & 247.548.264 & 1 & 5.359.765 & 1 & 51.631 .841 & 1 \\
\hline
\end{tabular}




\subsection{Setores-chave}

De acordo com Mc Gilvray, 1977 (in Guilhoto et al., 1994), dentro de um conceito mais restrito, os setores-chave são aqueles que apresentam tanto $o$ indice de ligações para trás como para frente com valores maiores do que 1. De acordo com esse conceito, pode-se observar que, em 1990 , os setores 4 - Metalurgia; 5 - Mecânica e Material Elétrico; 13 - Indústria Têxtil; satisfazem essa condição. Já em 1991, os setores 4 - Metalurgia e 13 - Indústria Têxtil continuam satisfazendo essa condição e o setor 10 - Indústria Quimica ocupa a posição substituindo o setor 5 - Mecânica e Material Elétrico. A partir de 1992 apenas os dois setores 4 - Metalurgia e 13 - Indústria Têxtil atendem à condição mencionada. Por ser este conceito restrito como já foi dito, deixa de lado setores que apresentam altos valores em apenas um dos indices.

Se esse conceito for menos limitado e considerando-se como setor-chave aquele que apresentar um indice de ligações para trás ou um indice de ligações para frente com valores maiores do que 1 aumenta o universo de setores, de modo que um critério intermediário se faz necessário.

Guilhoto \& Picerno (1995) sugerem verificar os maiores indices de ligações para frente e para trás e aqueles que satisfazem o conceito mais restrito de setor-chave, para a obtenção de um critério intermediário. Utilizando-se esse critério para selecionar os principais setores da economia, outros setores-chave seriam 6 - Material de Transporte, 16 - Produtos Alimentares, 15 - Calçados e Couros, 14 - Vestuário, 8 Papel e Papelão, 20 - Transporte e M. Comércio, 21 - Serviços e 1 - Agropecuário, considerando-se o periodo analisado. Tal definição de setor-chave levou em consideração apenas a estrutura da demanda por insumos setoriais.

Os indices puros totais de ligação encontram-se na Tabela 5.30. Nesse caso, os indices de ligação para frente e para trás são somados, sendo considerados setoreschave na economia aqueles que apresentarem os maiores valores para esse indice. $\dot{E}$ 
importante chamar a atenção para o fato de que o enfoque do índice puro mostra a importância dos setores para a economia brasileira, importância derivada do volume de produção nesses setores.

Os resultados dos índices puros de ligações totais (PTL), revelam os setores com maior impacto com o setor "j" demandando da economia e a economia demandando do setor “j”, em ordem decrescente de importância, em 1990: 21 Serviços; 20 - Transporte e M. Comércio; 16 - Produtos Alimentares; 19 - Construção Civil e 10 - Indústria Química. A partir da consolidação do MERCOSUL, em 1991, os setores com maior impacto continuam sendo os cinco já apresentados, apenas mudando a ordem. Nota-se que, em 1994, o setor 1 - Agropecuária passa a ocupar posição entre os cinco, substituindo o setor 19 - Construção Civil.

Em síntese, após compararmos os resultados obtidos a partir dos índices puros de ligações, combinado com os padrões de ligações fortes expressos pelos índices de Rasmussen/Hirschman e os coeficientes setoriais com maior campo de influência, conclui-se que os setores estratégicos da economia para o período analisado, são: 1 Agropecuária; 4 - Metalurgia; 5 - Mecânica e M. Elétrico; 6 - Material de Transporte; 8 - Papel e Papelão; 10 - Indústria Química; 13 - Indústria Têxtil; 16 - Produtos Alimentares; 19 - Construção Civil; 20 - Transporte e M. Comércio e 21 - Serviços. 


\subsection{Campo de influência}

De acordo com Guilhoto et al., 1994, o enfoque de campo de influência está relacionado com os resultados agregados dos índices de Rasmussen - Hirschman, ou seja, os setores que possuem simultaneamente os valores dos índices de ligações para trás e para frente maiores do que 1.

$\mathrm{Na}$ abordagem introduzida por Hewings et al. (1989), através da análise a partir do enfoque de campo de influência, os resultados mostram que as relações na economia são dominadas basicamente pelos setores 4 - Metalurgia e 13 - Indústria Têxtil ao longo do período analisado. Cabe salientar que, em 1992, os setores 6 Material de Transporte, 8 - Papel e Papelão, 9 - Borracha, 10 - Indústria Química e 16 - Produtos Alimentares, também apresentaram resultados conforme a abordagem introduzida por Hewings et al. (1989).

A análise dos indices de ligações de Rasmussen/Hirschman aponta Produtos Alimentares, Construção Civil, Serviços, Transporte e M. Comércio e Mecânica e Material Elétrico como setores-chave da economia brasileira, para o período analisado.

O enfoque de campo de influência complementa a análise das ligações de Rasmussen e Hirschman permitindo visualizar as ligações mais fortes entre os setores, onde os resultados mostram que as relações da economia são dominadas pelos setores Metalurgia e Têxtil (ver Figuras 5.36 a 5.40).

Em suma, as análises realizadas fornecem algumas conclusões a respeito dos impactos da integração MERCOSUL sobre a economia brasileira, no período analisado. O MERCOSUL não apresentou alterações latentes na estrutura produtiva, mas alterou em parte a composição da demanda final, ou seja, o consumo das famílias. 


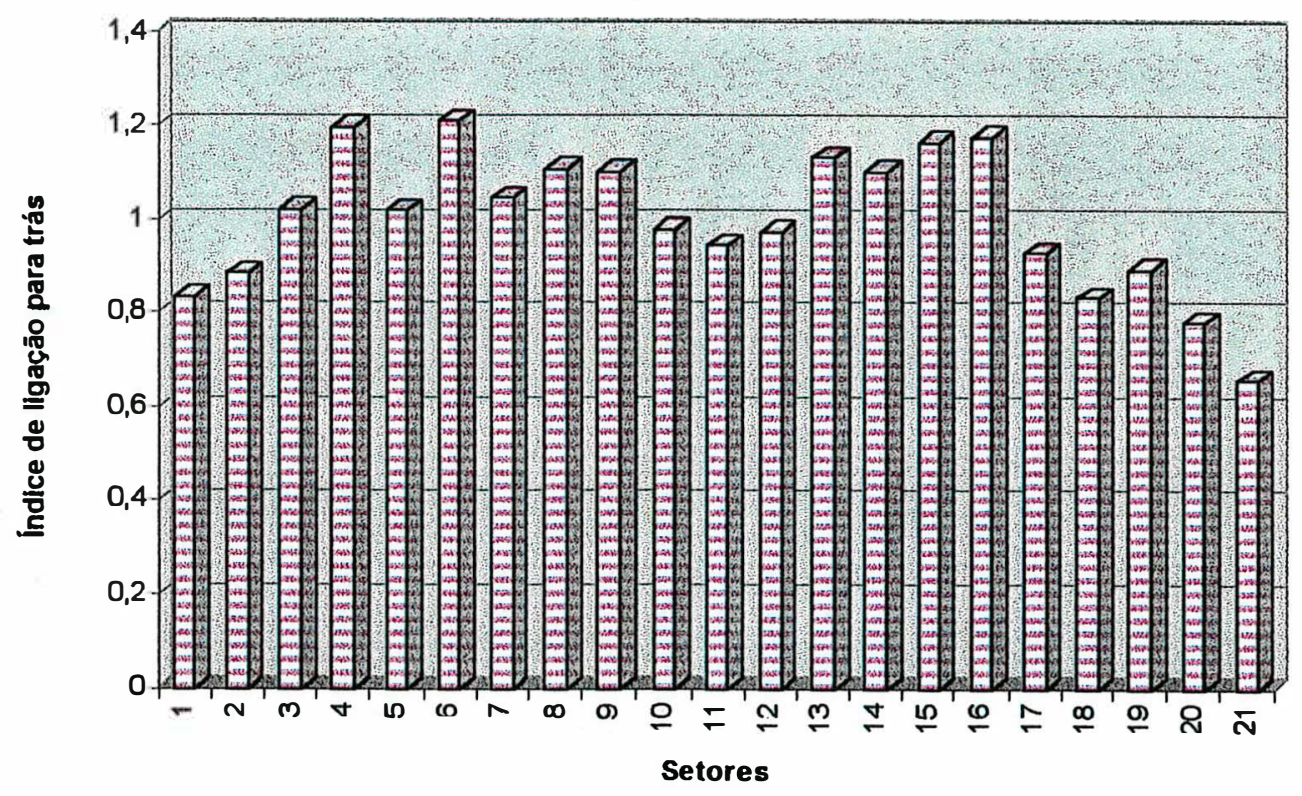

Figura 5.1 - Rasmussen/ Hirshman - 1990

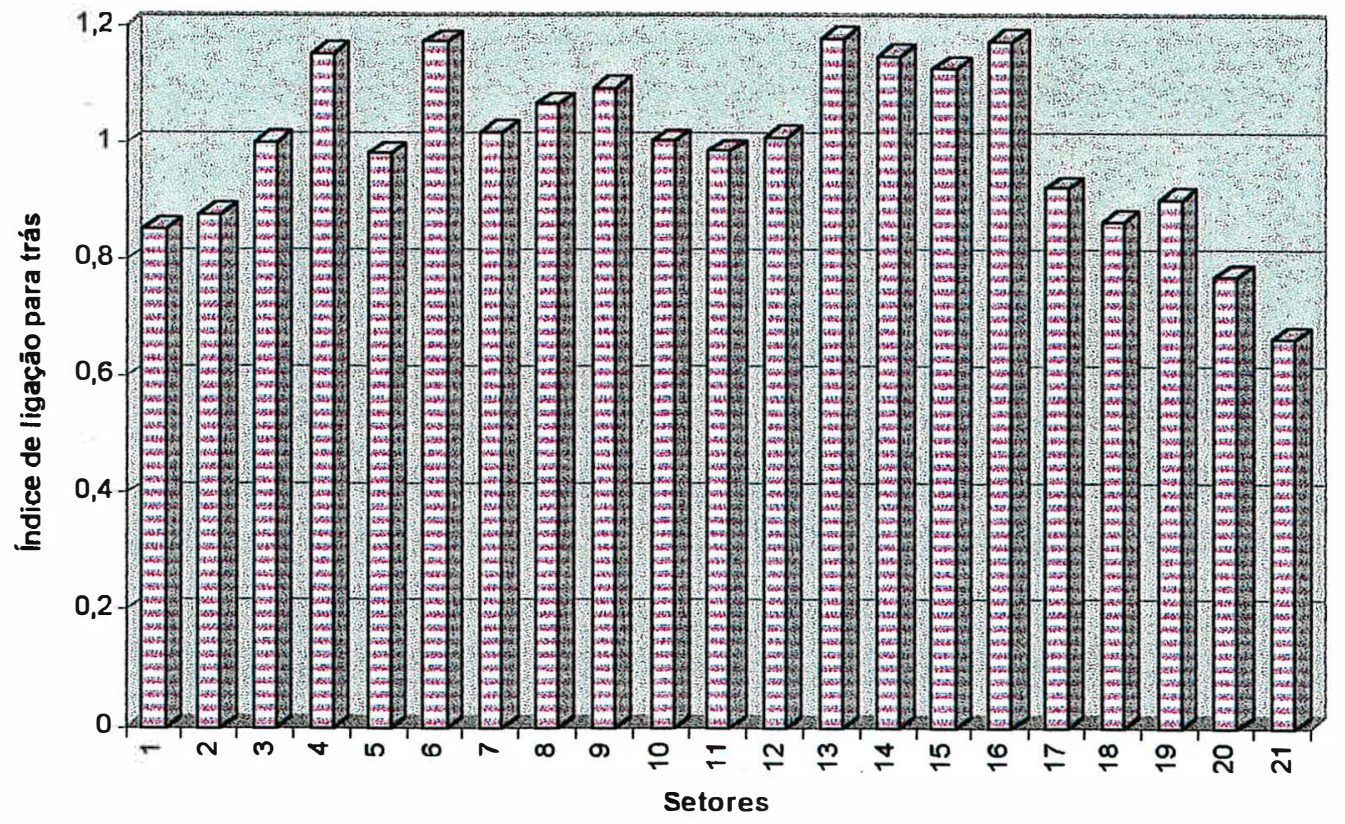

Figura 5.2 - Rasmussen/ Hirschman - 1991 


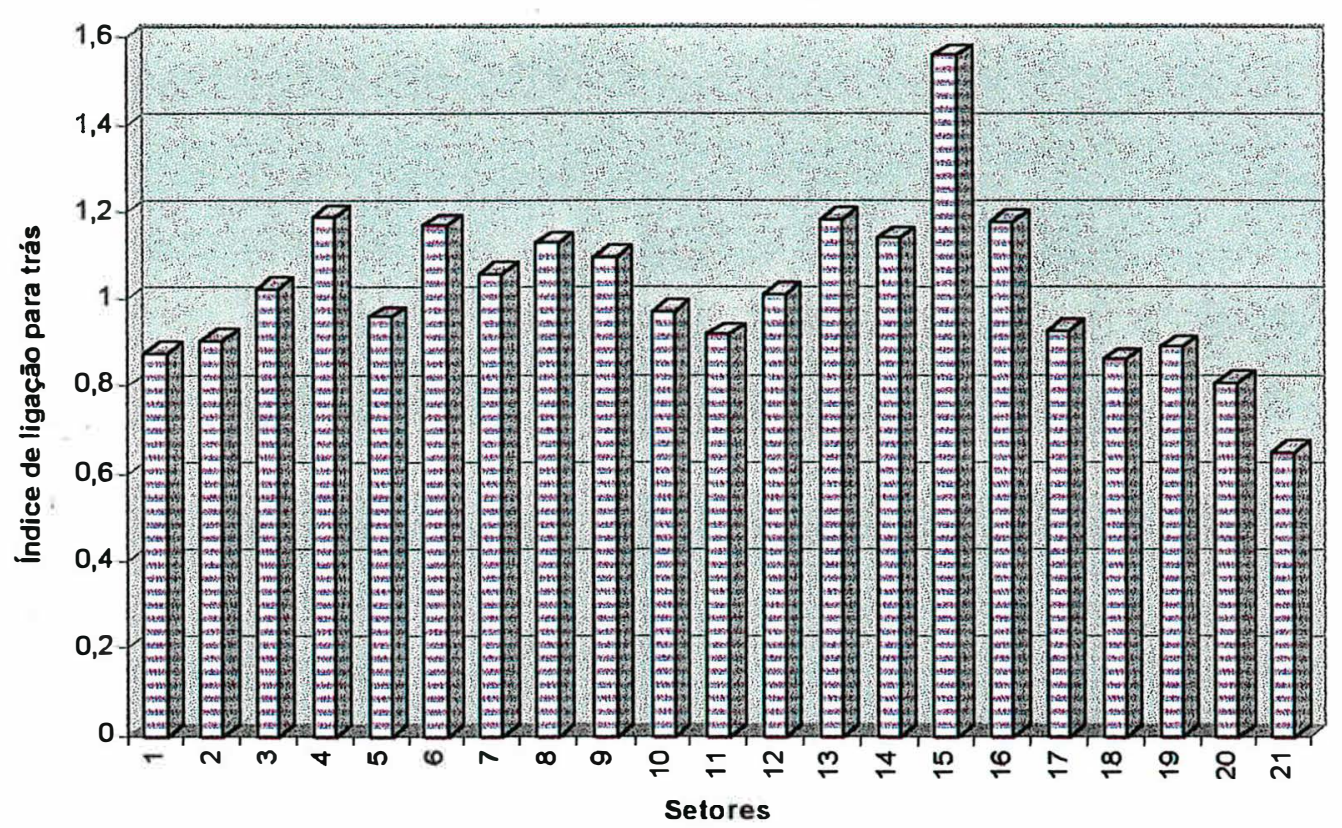

Figura 5.3 - Rasmussen/ Hirschman - 1992

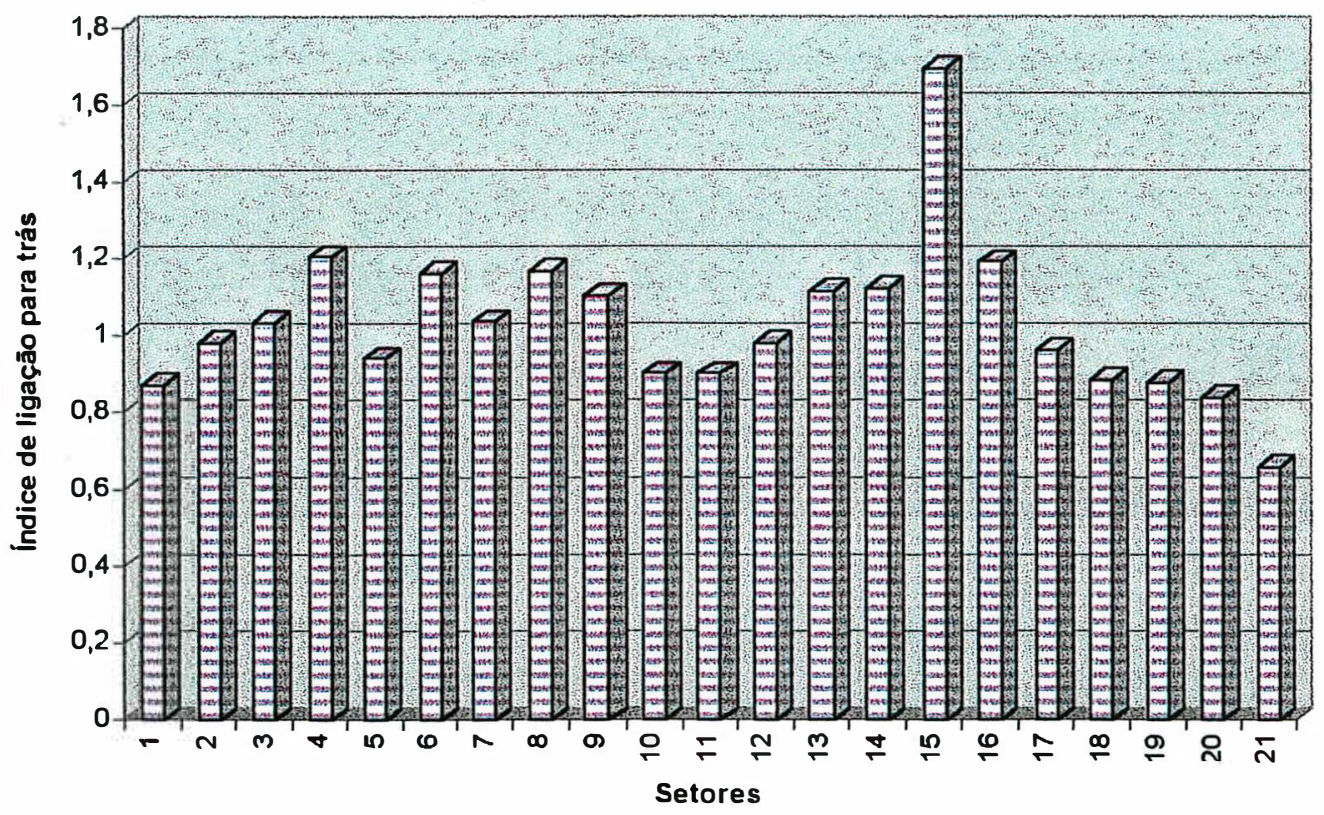

Figura 5.4 - Rasmussen/ Hirschman - 1993 


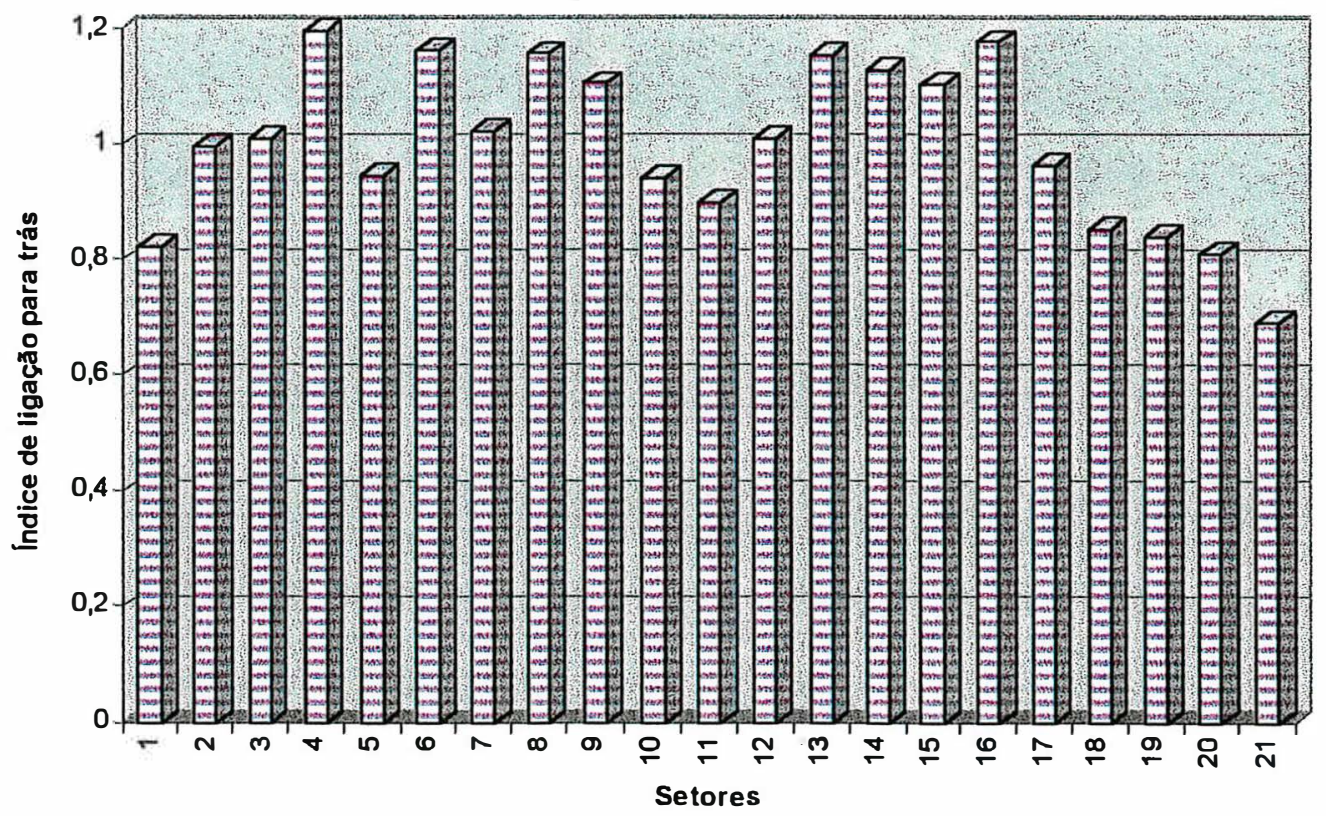

Figura 5.5 - Rasmussen/ Hirschman - 1994

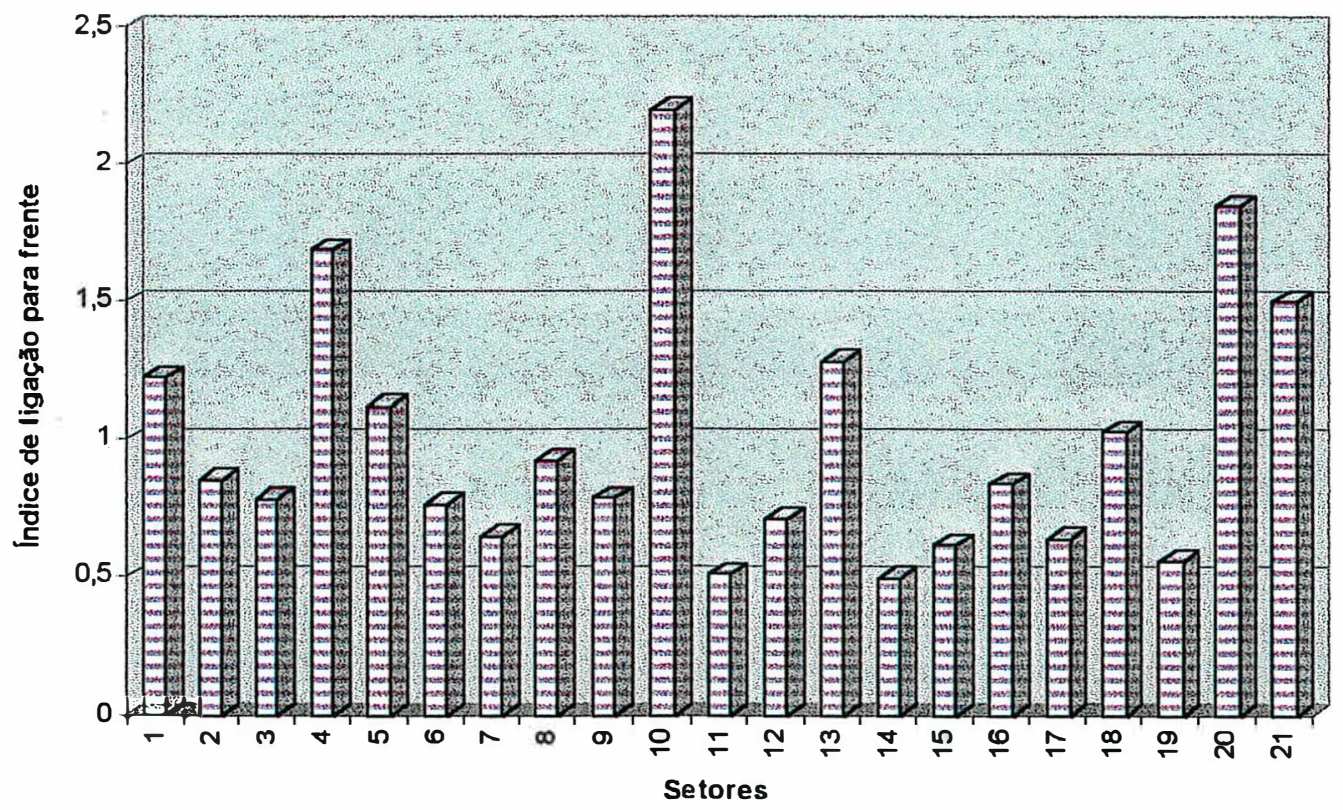

Figura 5.6 - Rasmussen/ Hirschman - 1990 


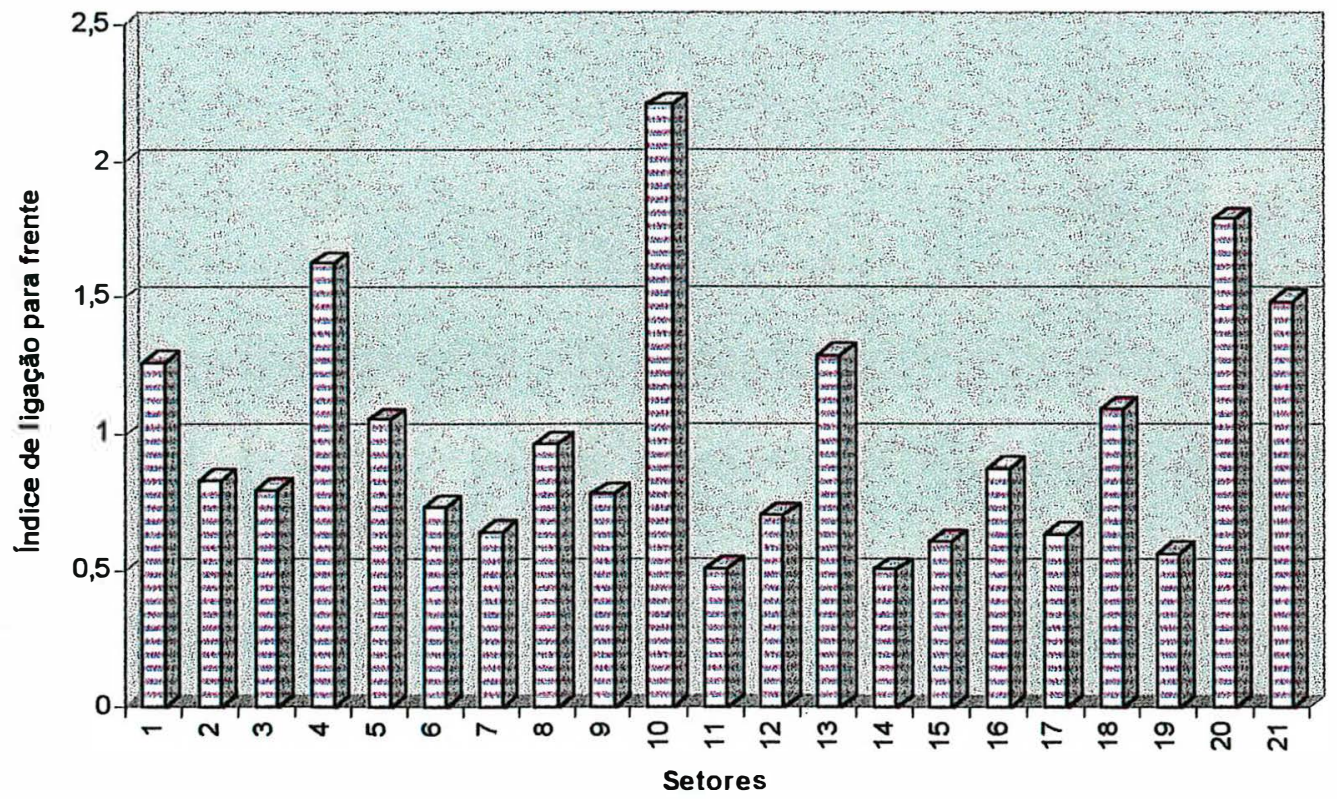

Figura 5.7 - Rasmussen/ Hirschman - 1991

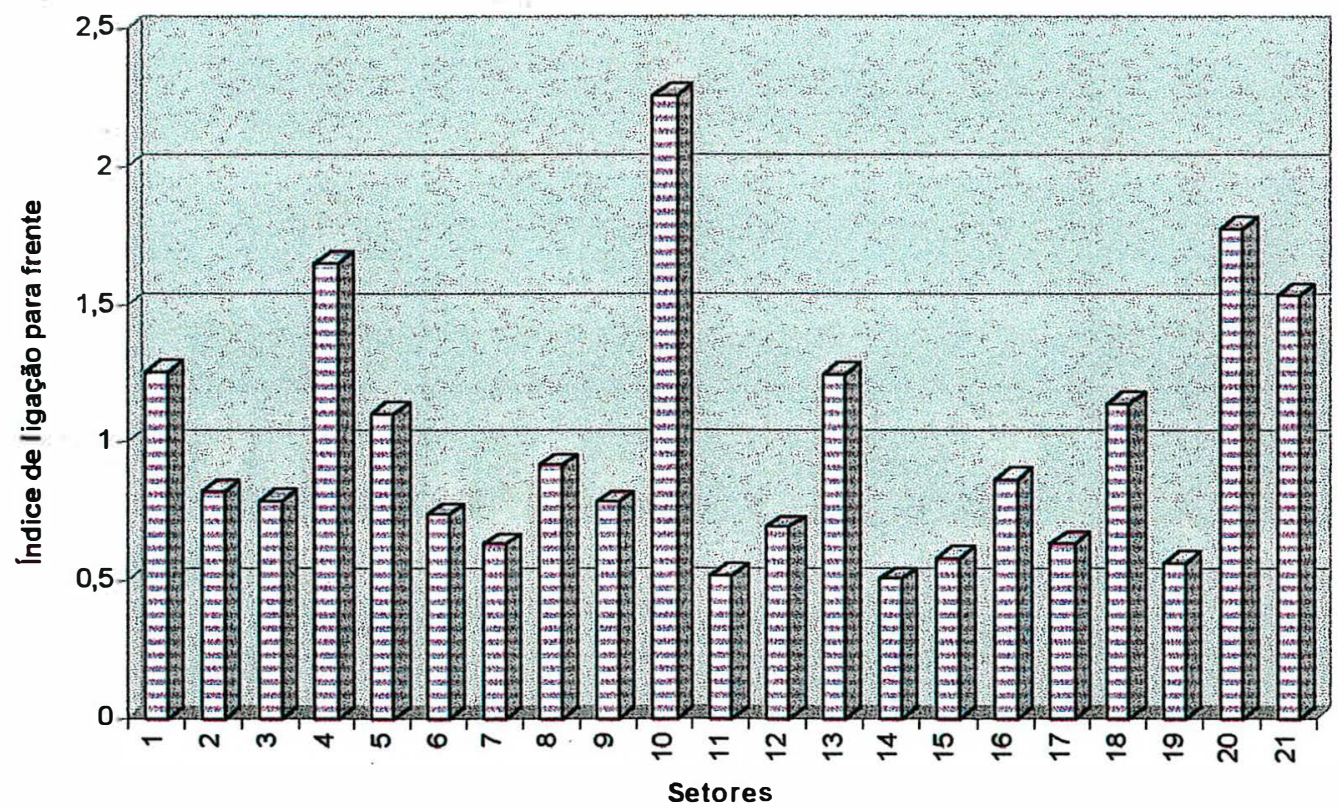

Figura 5.8 - Rasmussen/ Hirschman - 1992 


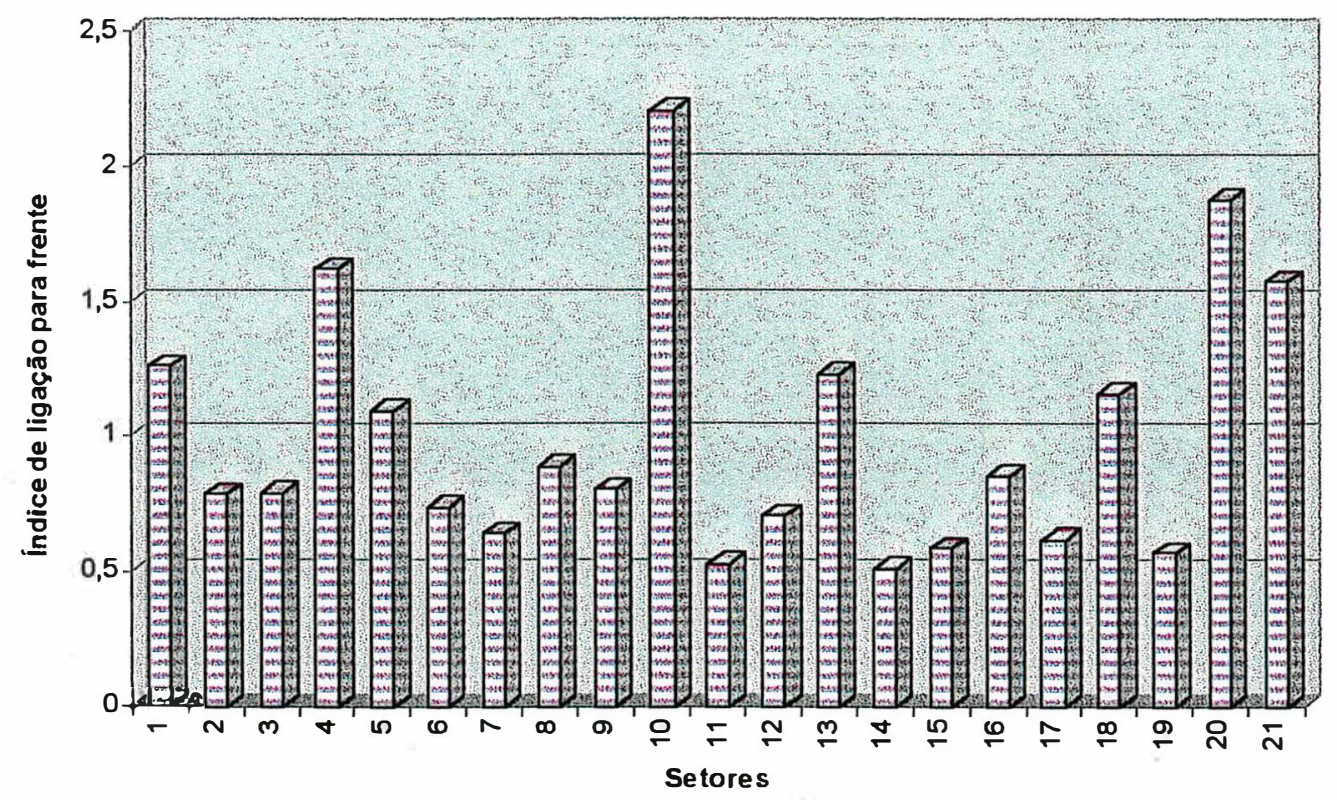

Figura 5.9 - Rasmussen/ Hirschman - 1993

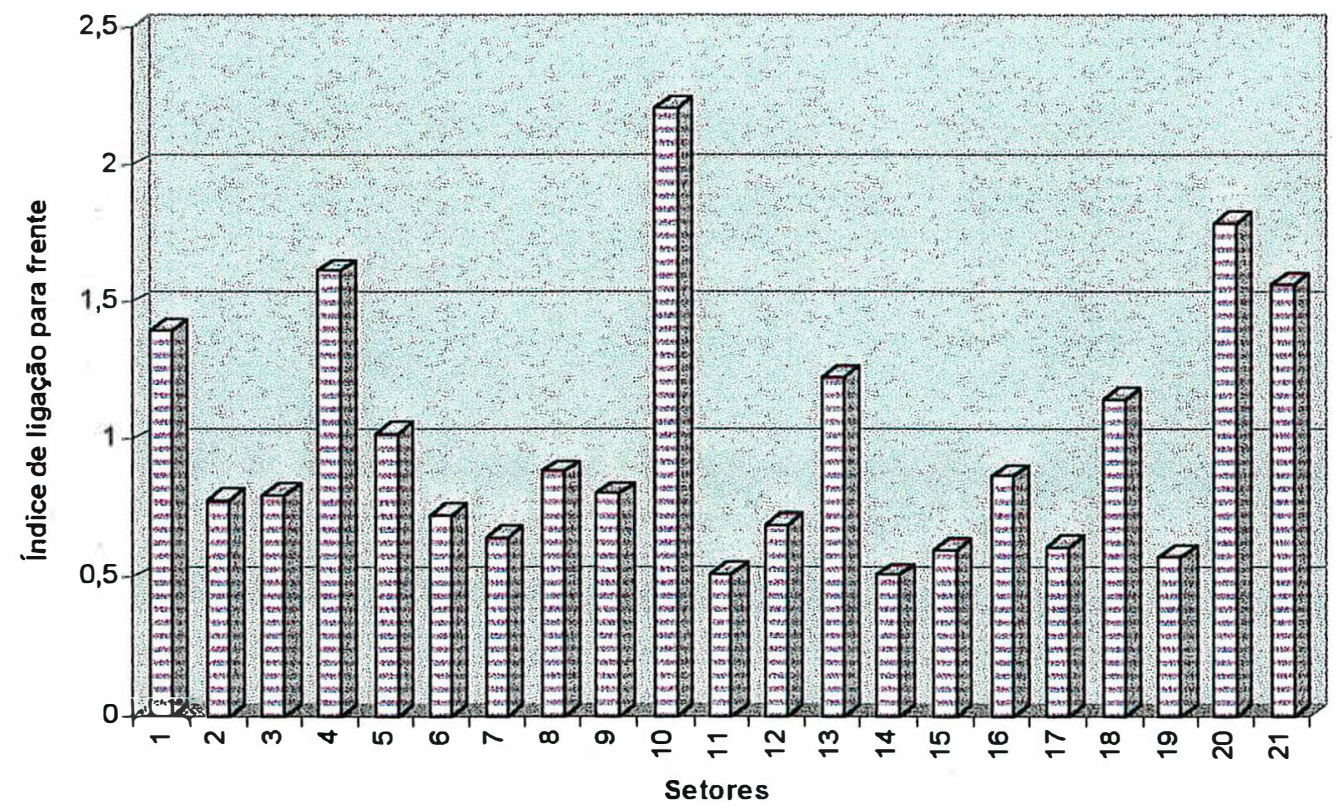

Figura 5.10 - Rasmussen/ Hirschman - 1994 


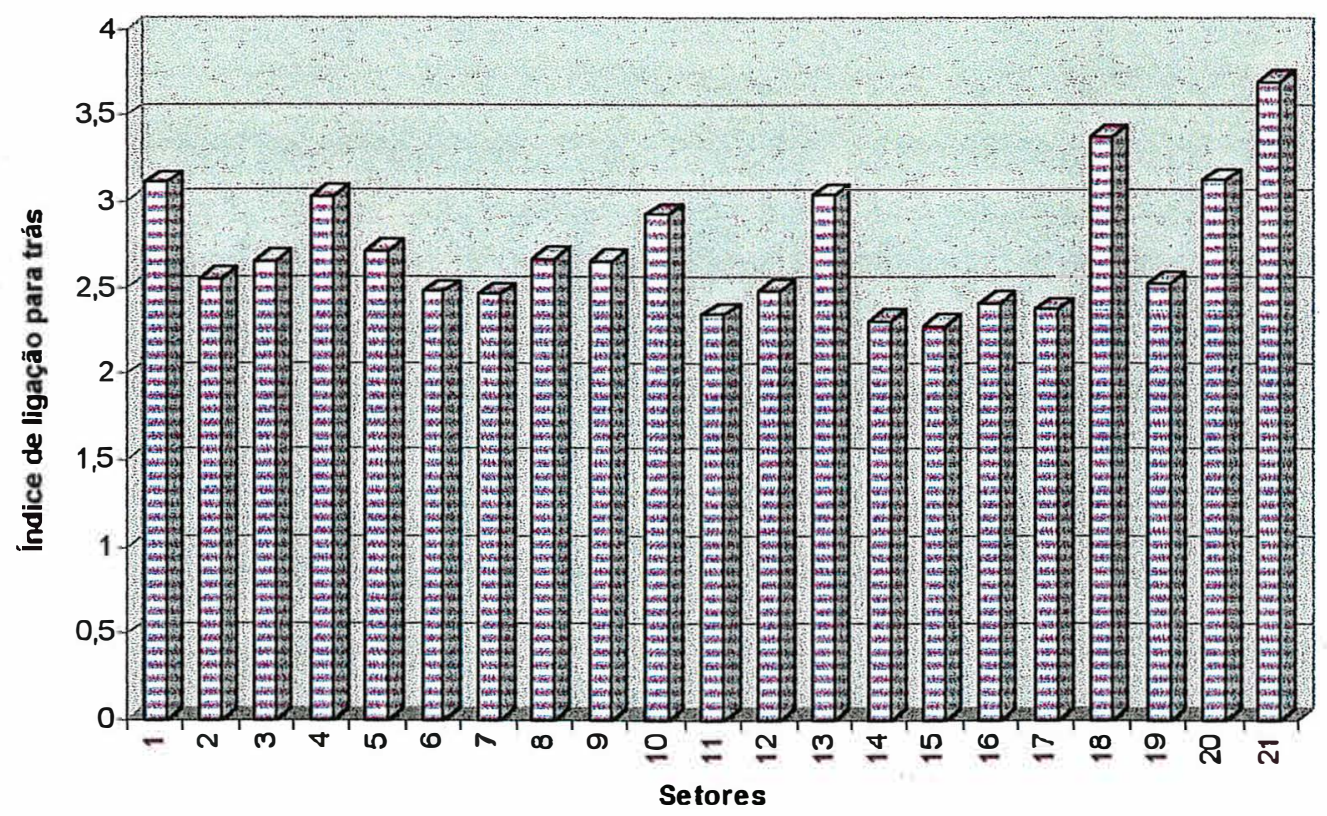

Figura 5.11 - Dispersāo -Rasmussen/ Hirschman - 1990

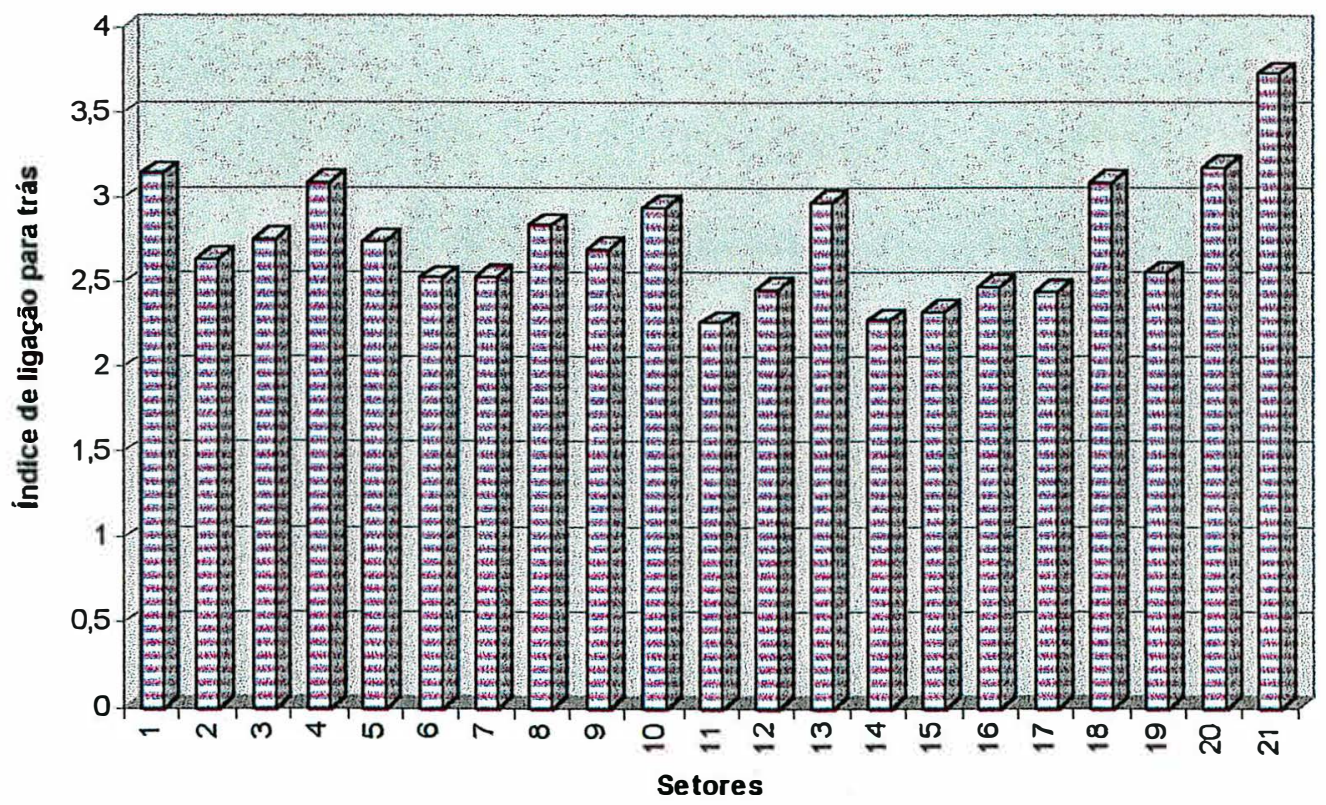

Figura 5.12 - Dispersāo - Rasmussen/ Hirschman - 1991 


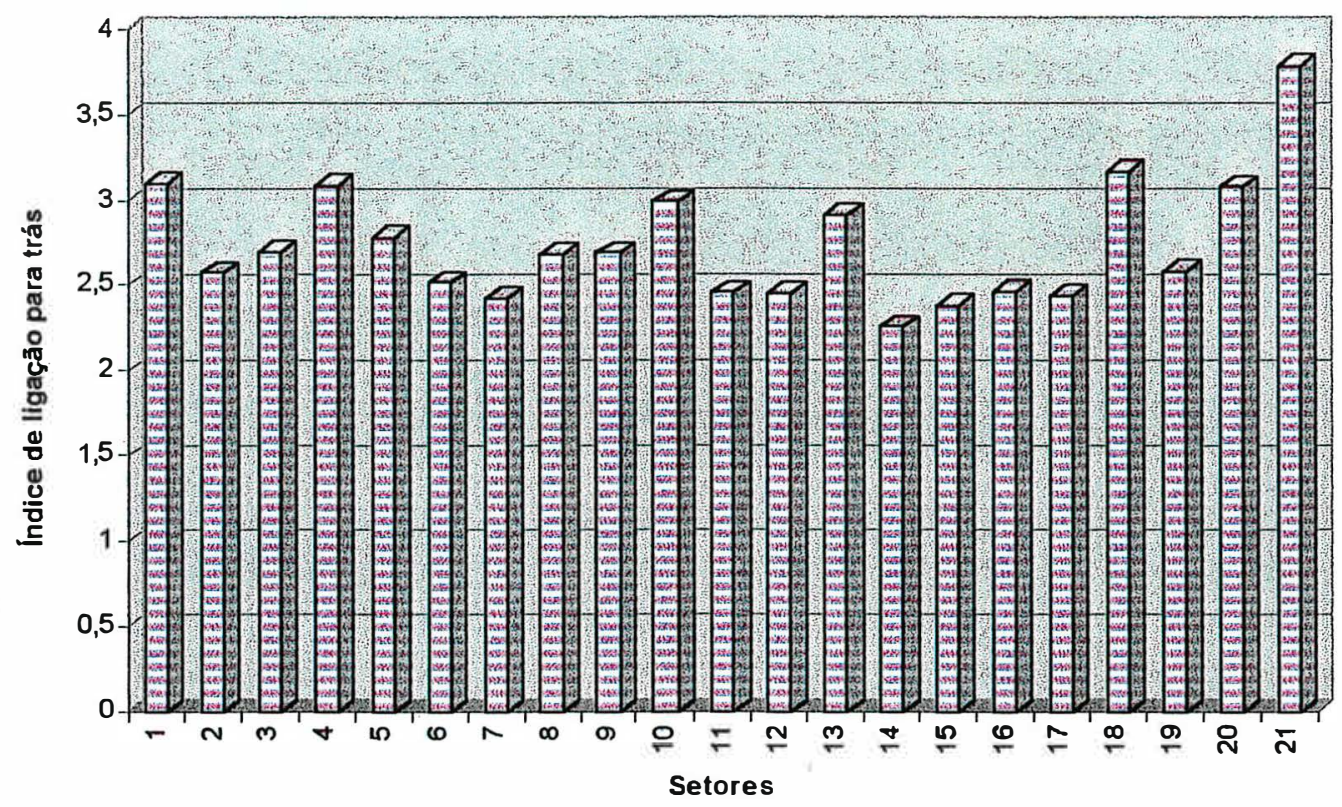

Figura 5.13 - Dispersāo - Rasmussen/ Hirschman - 1992

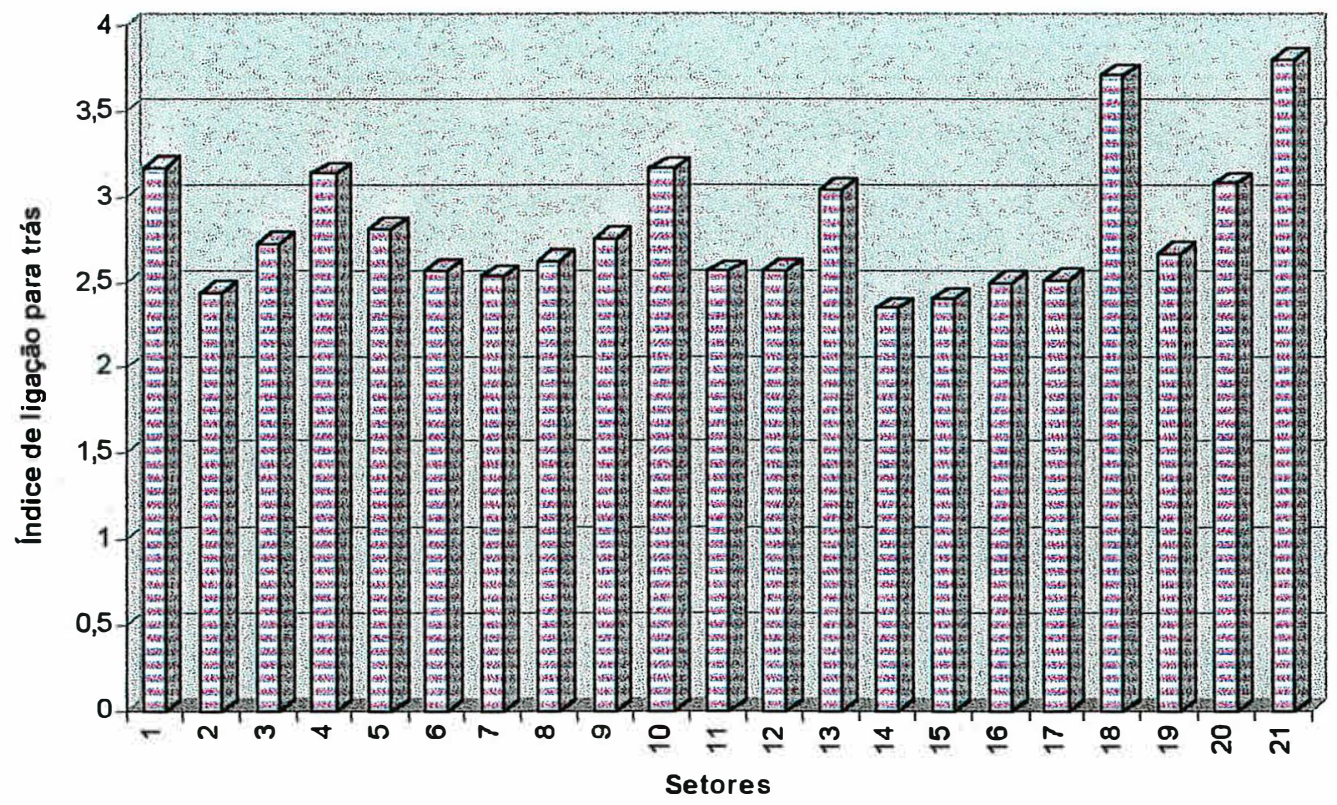

Figura 5.14 - Dispersāo - Rasmussen/ Hirschman - 1993 


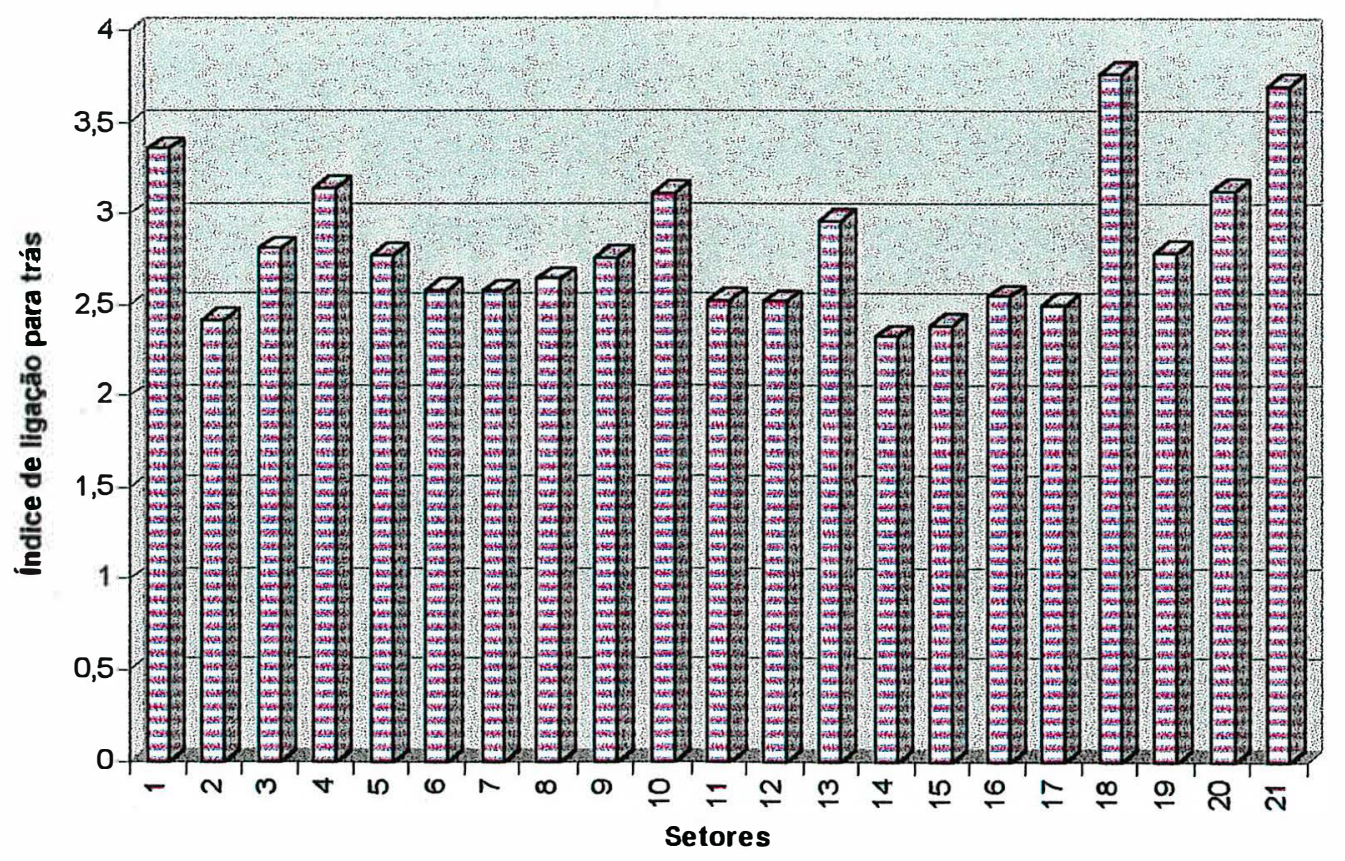

Figura 5.15 - Dispersão - Rasmussen/ Hirschman - 1994

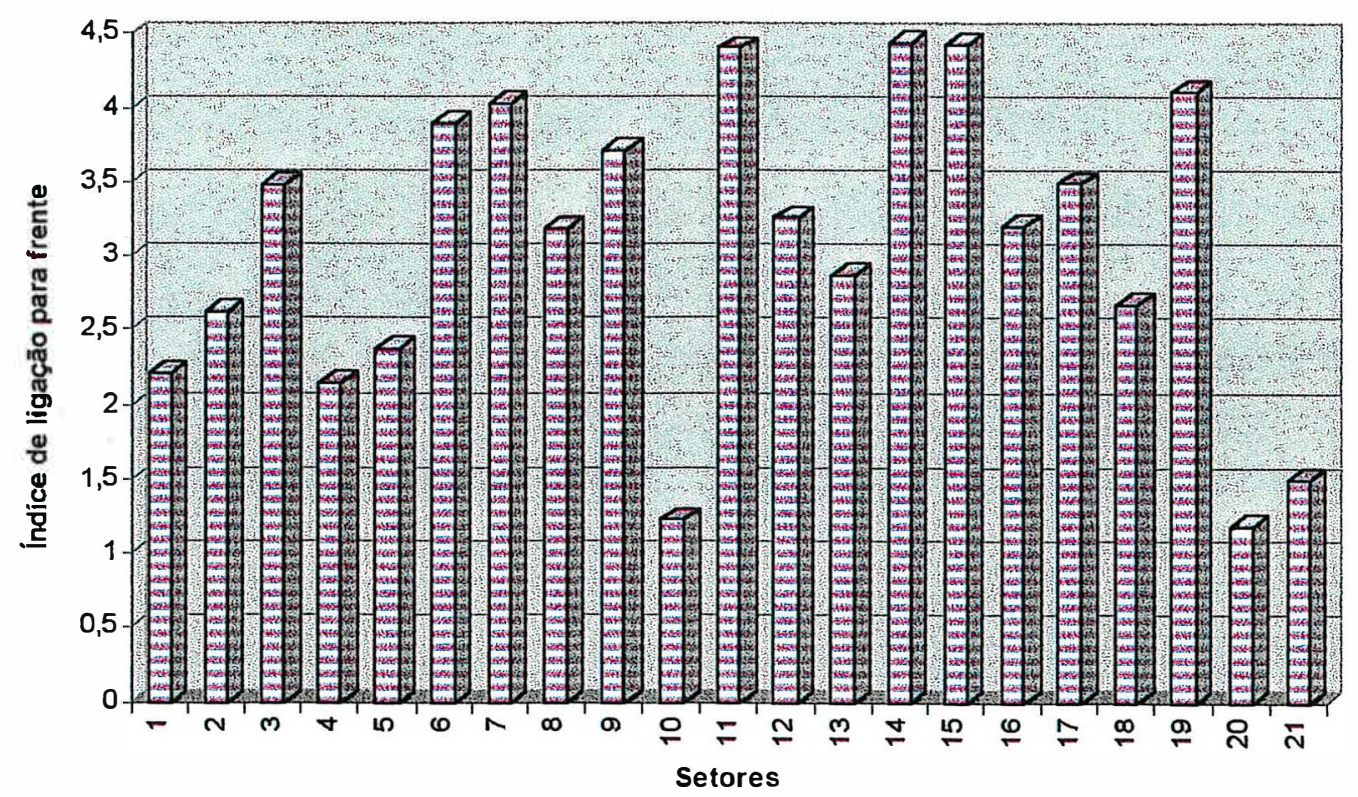

Figura 5.16 - Dispersão - Rasmussen/ Hirschman - 1990 


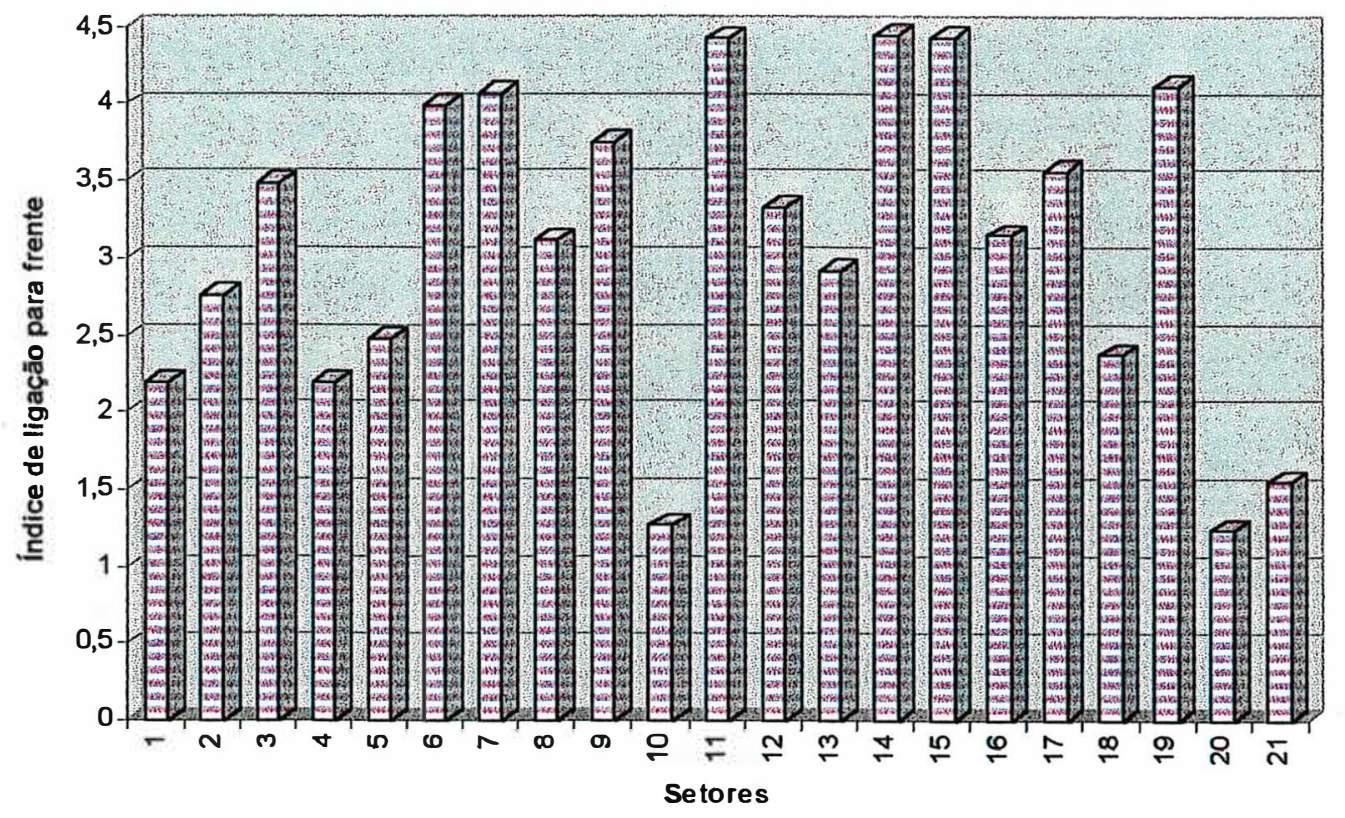

Figura 5.17 - Dispersāo - Rasmussen/ Hirschman - 1991

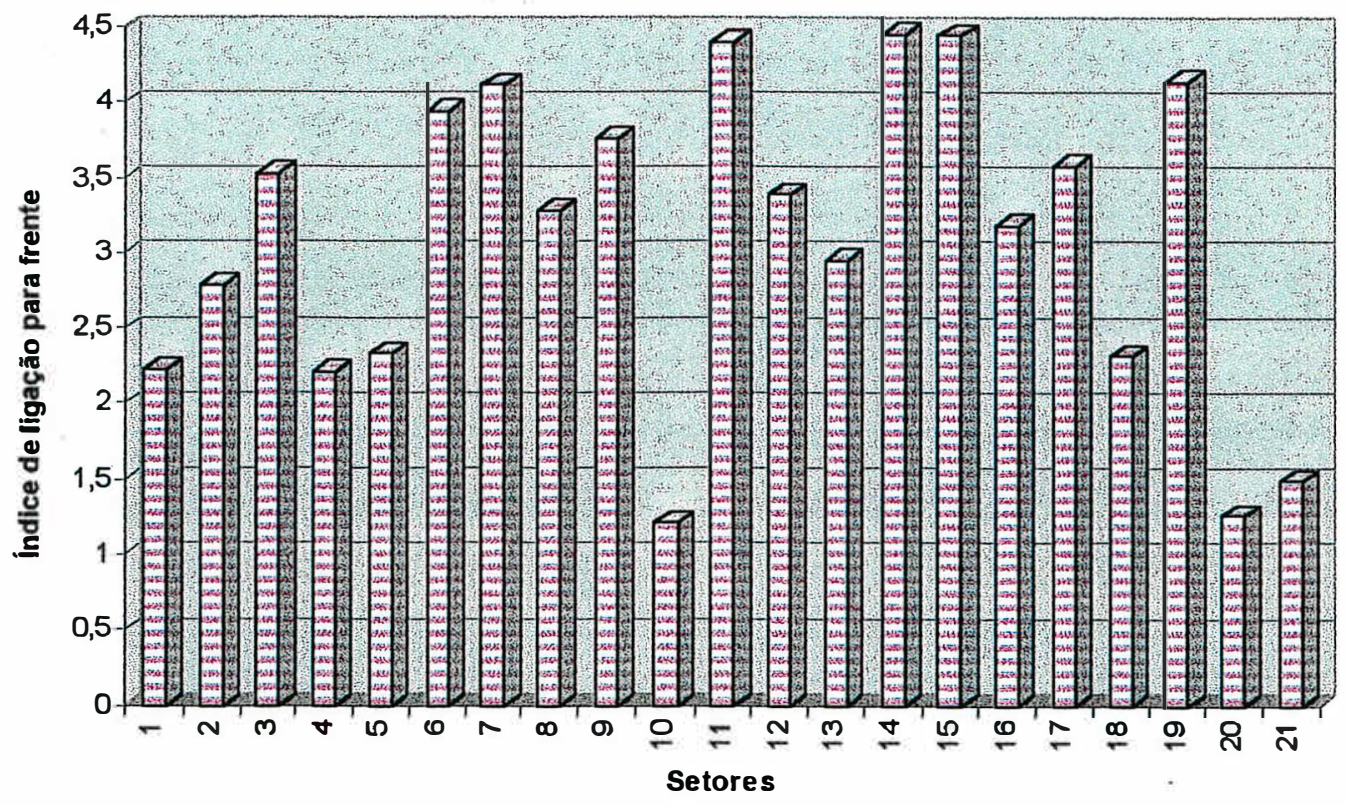

Figura 5.18 - Dispersāo - Rasmussen/ Hirschman - 1992 


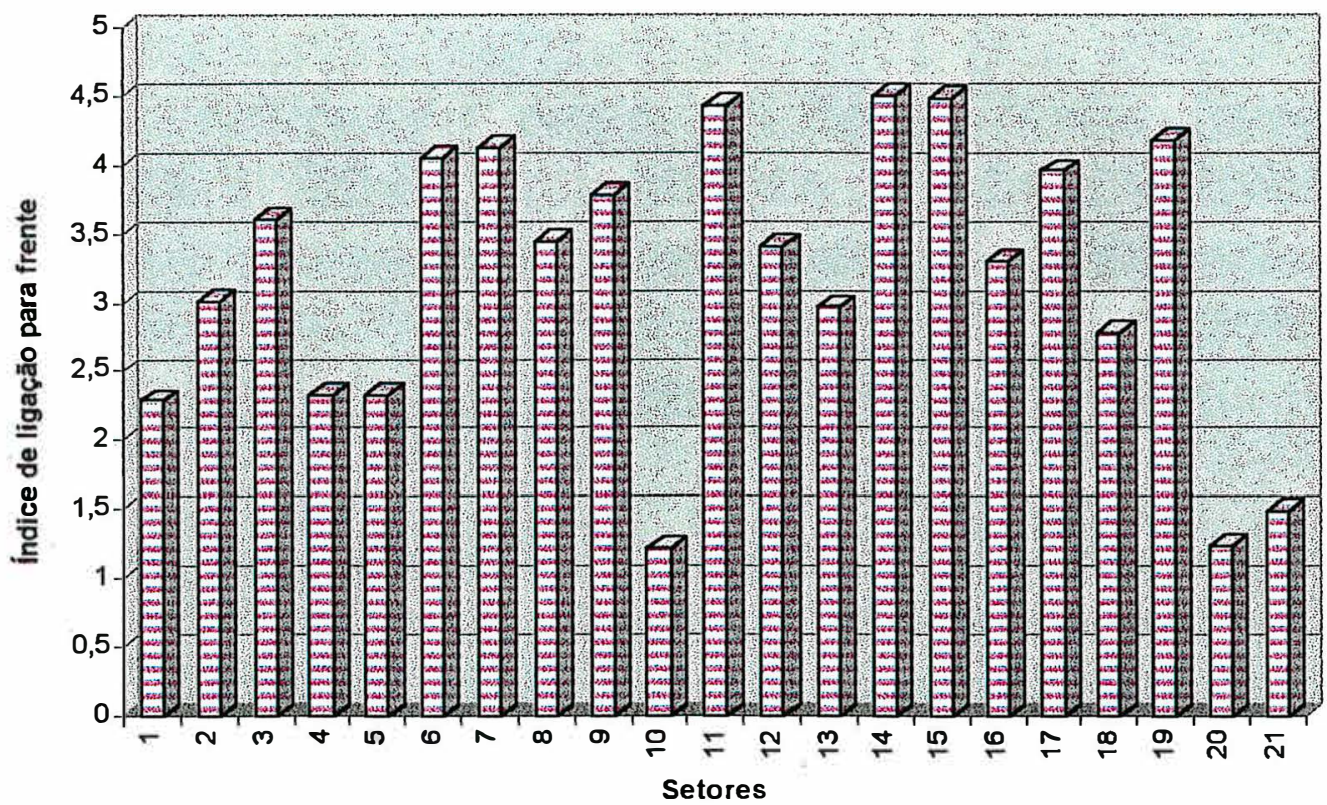

Figura 5.19 - Dispersāo - Rasmussen/ Hirschman - 1993

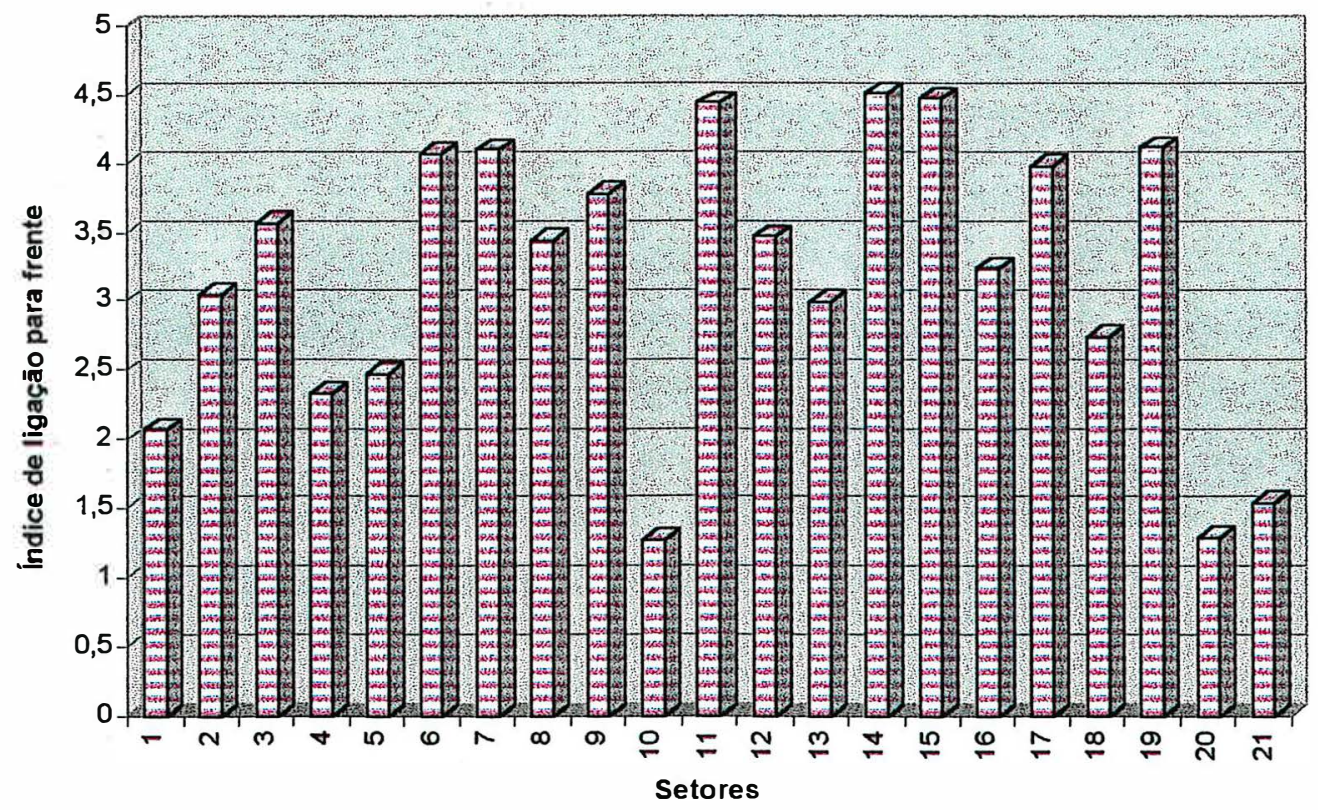

Figura 5.20 - Dispersāo - Rasmussen/ Hirschman - 1994 

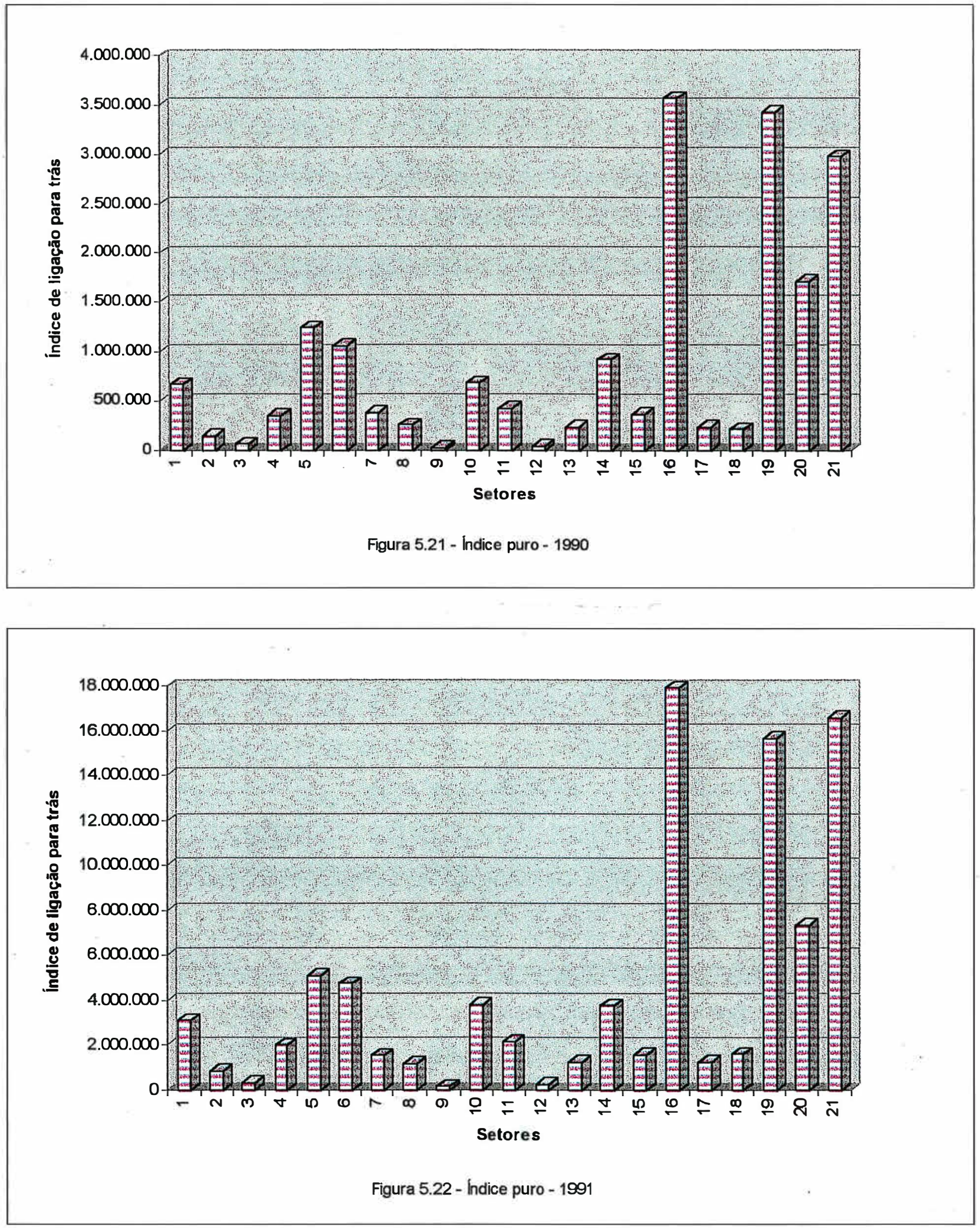

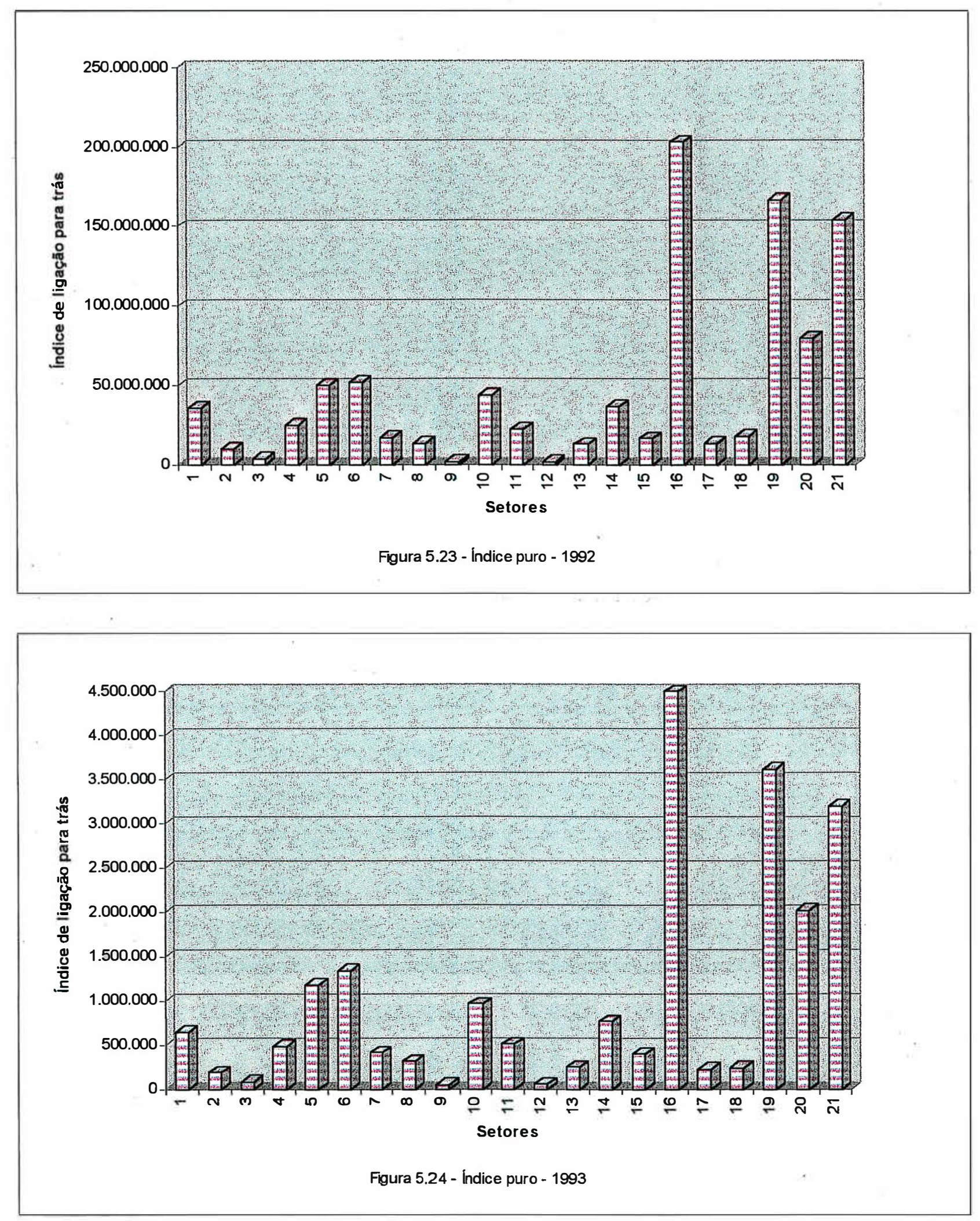

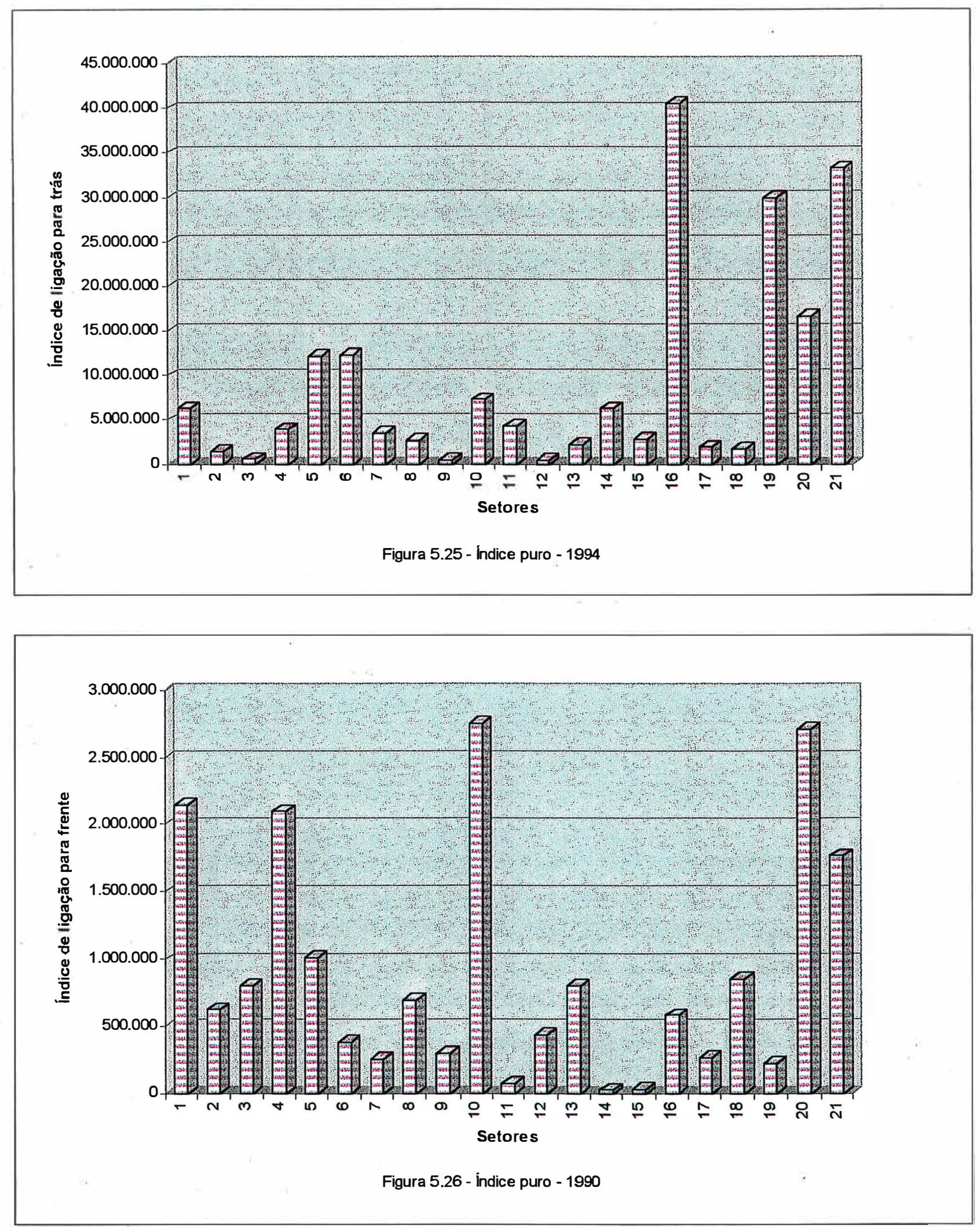

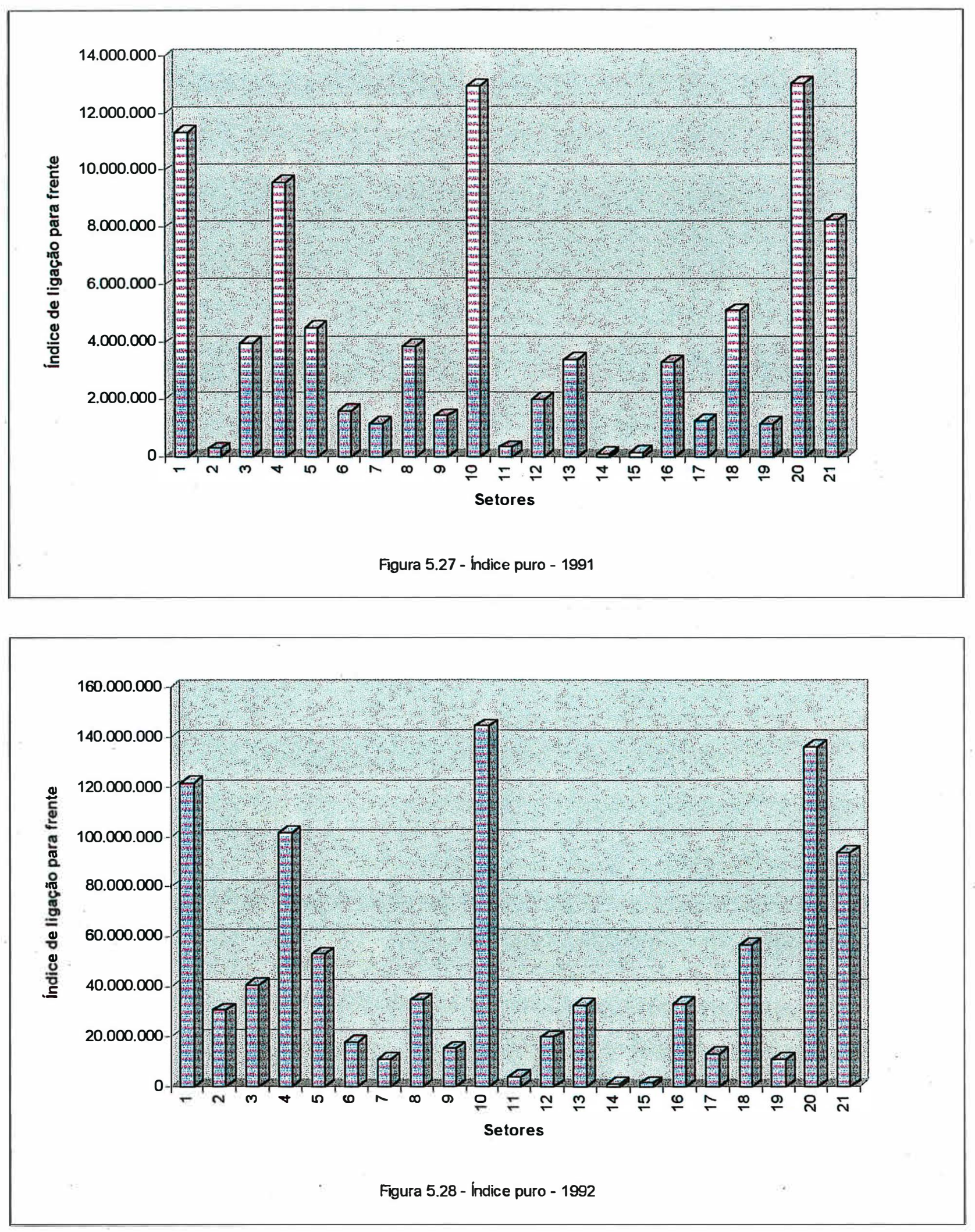


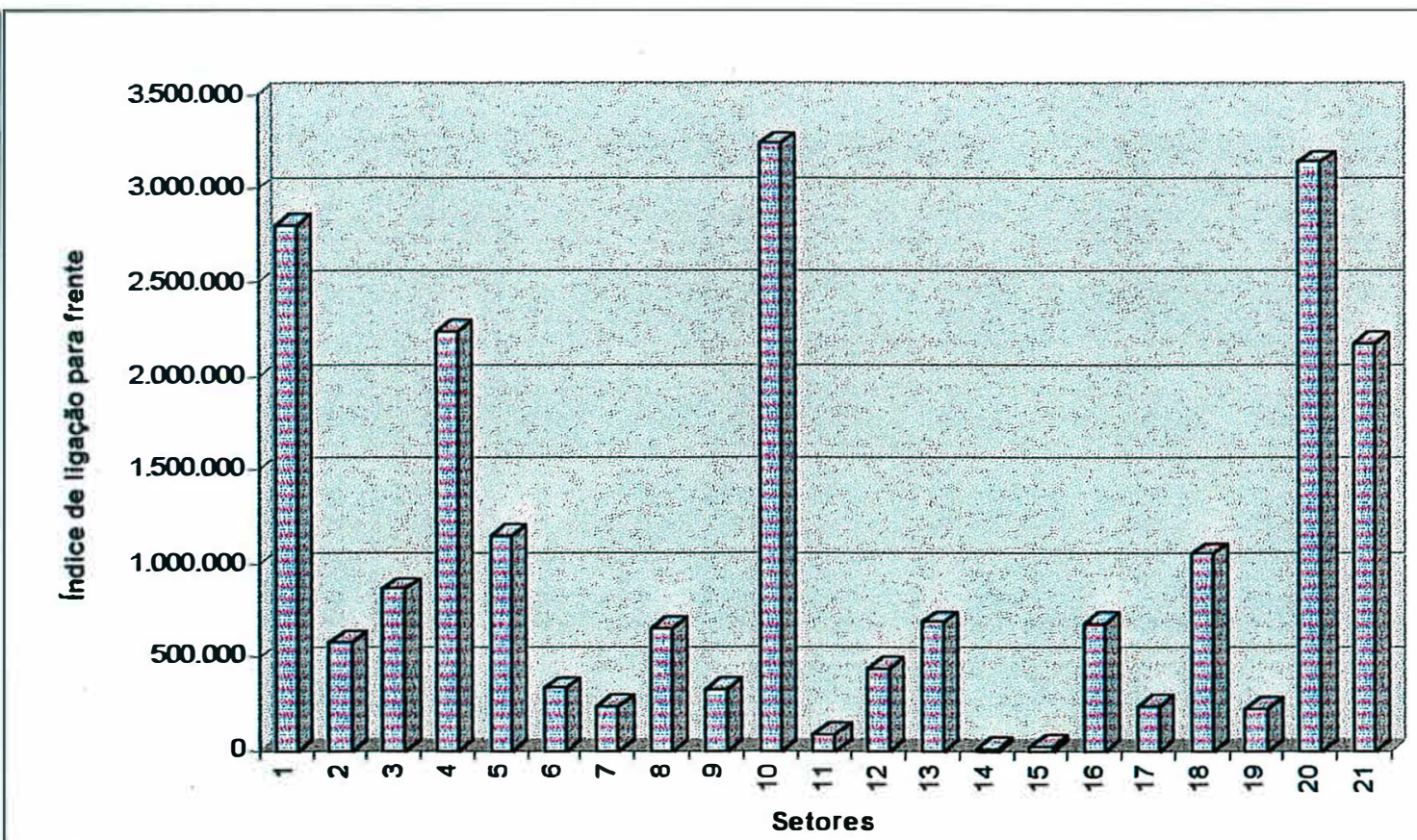

Figura 5.29 - hdice puro - 1993

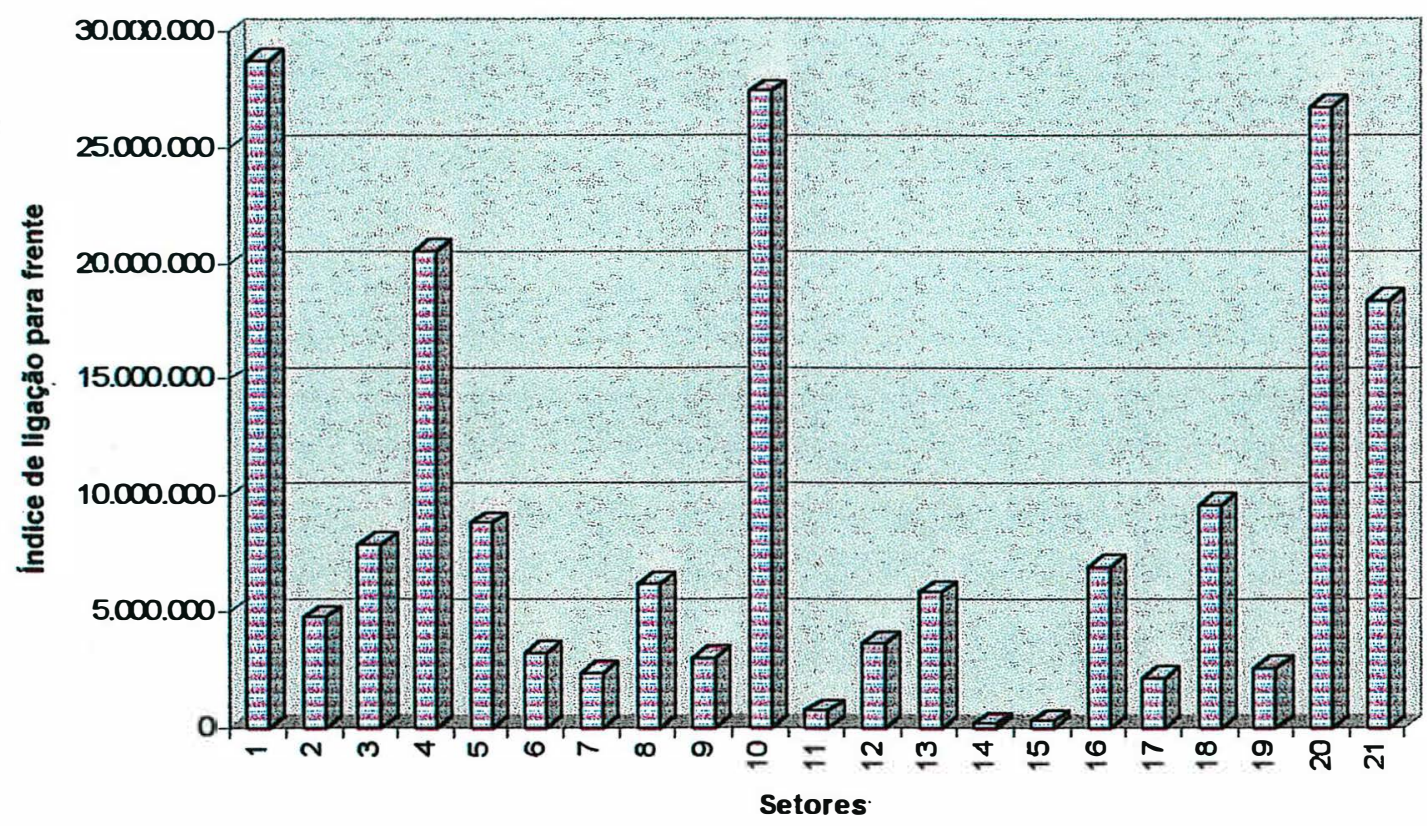

Figura 5.30 - hdice puro - 1994 

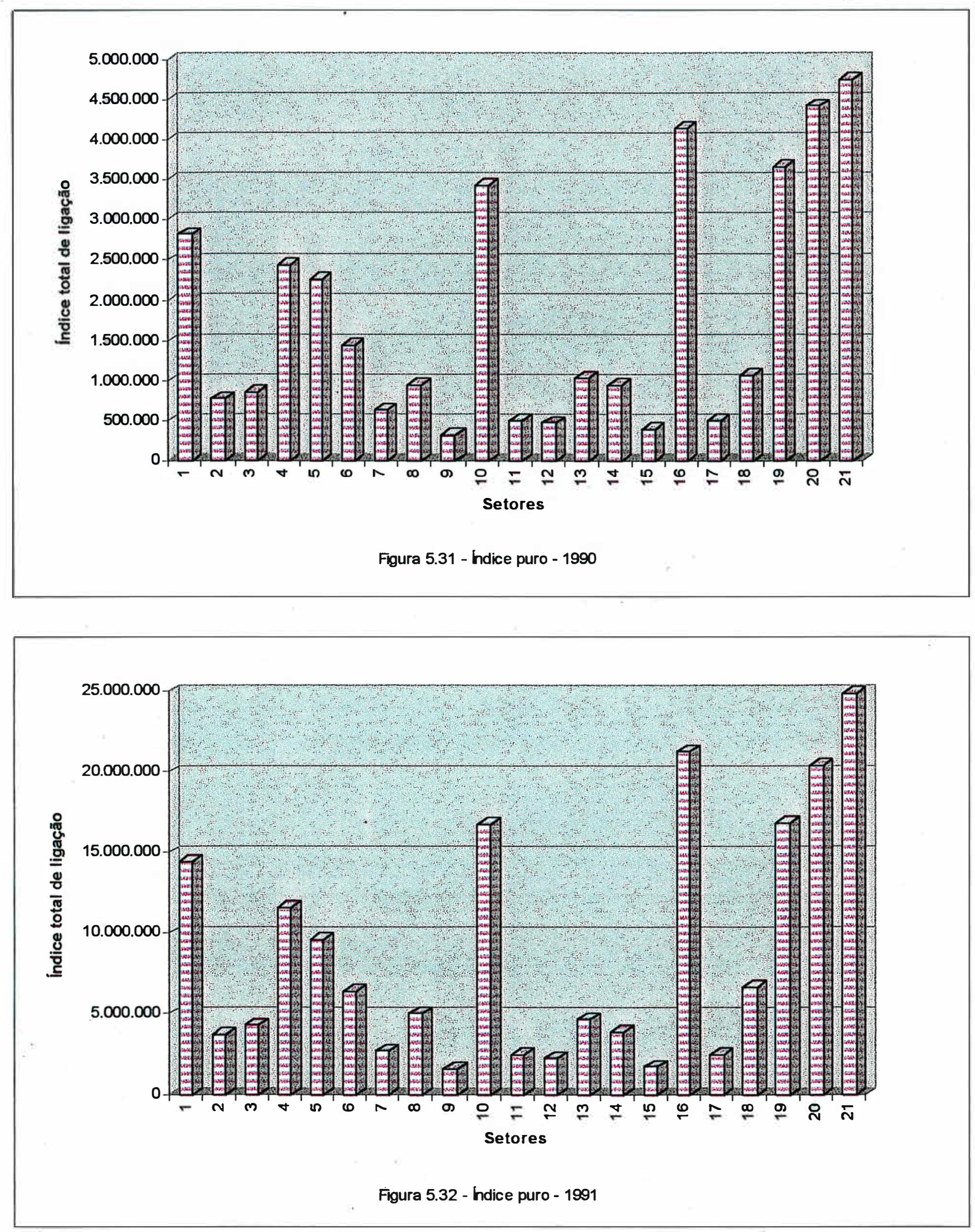


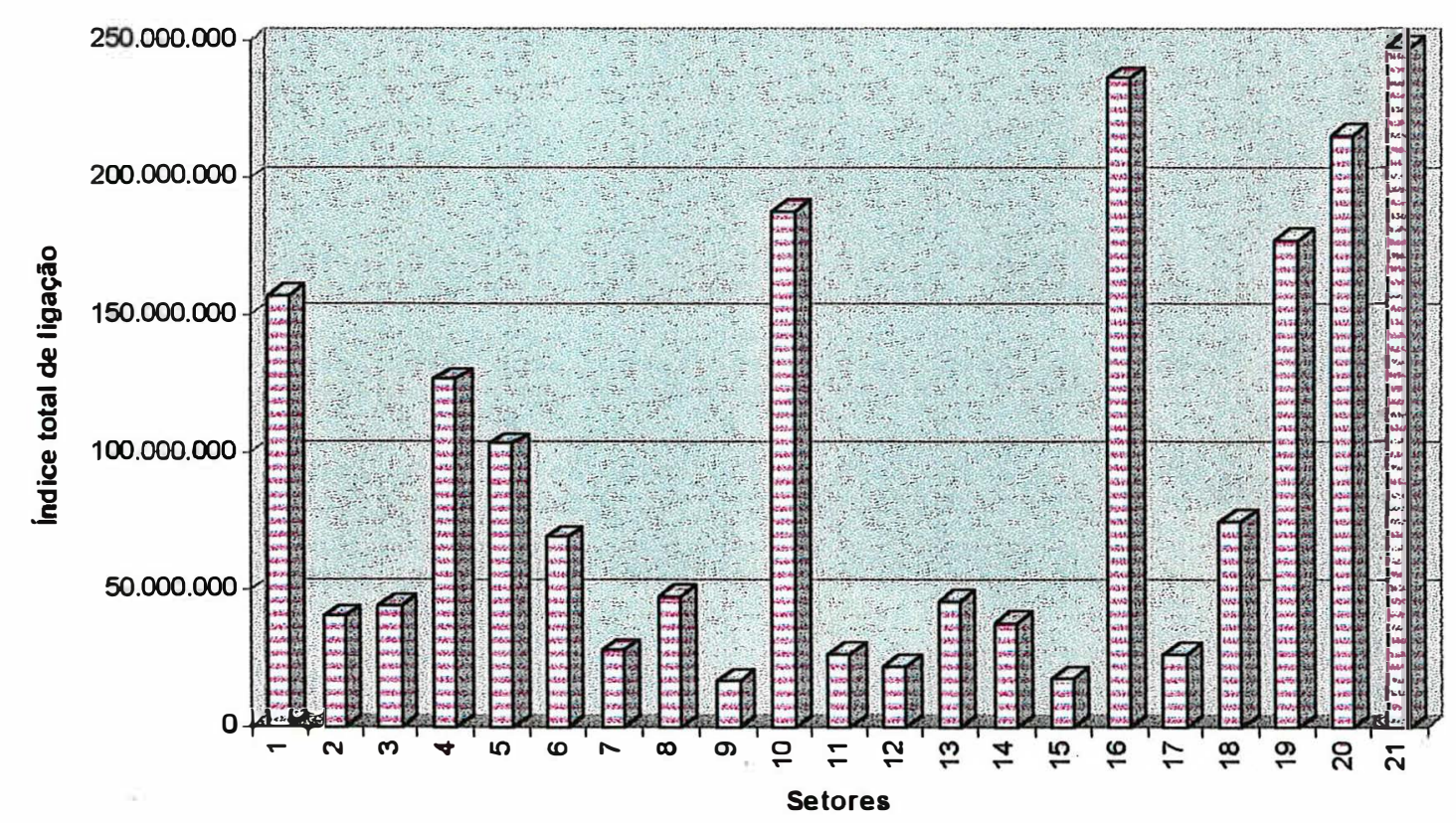

Figura 5.33 - Índice puro - 1992

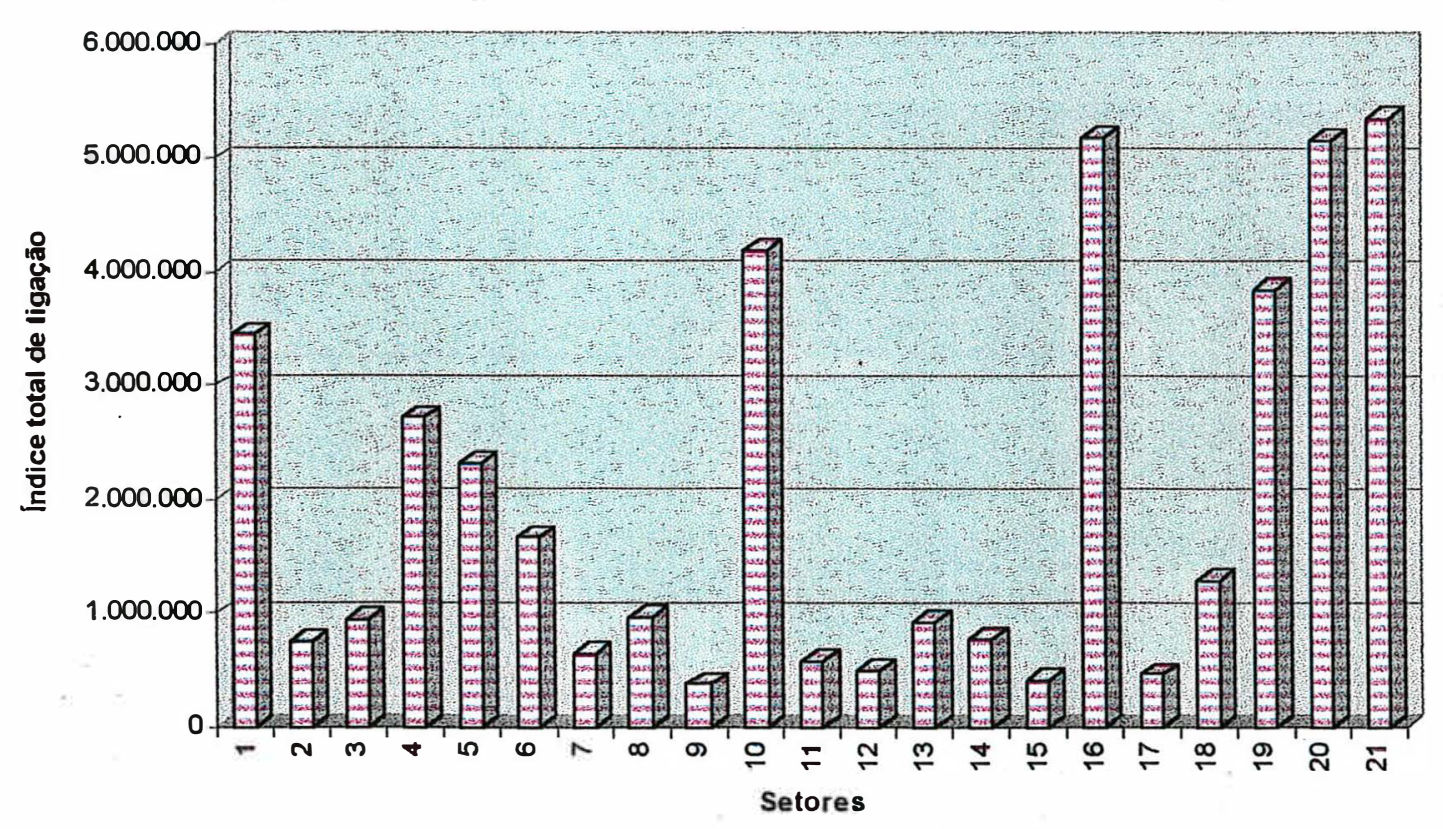

Figura 5.34 - Indice puro - 1993 


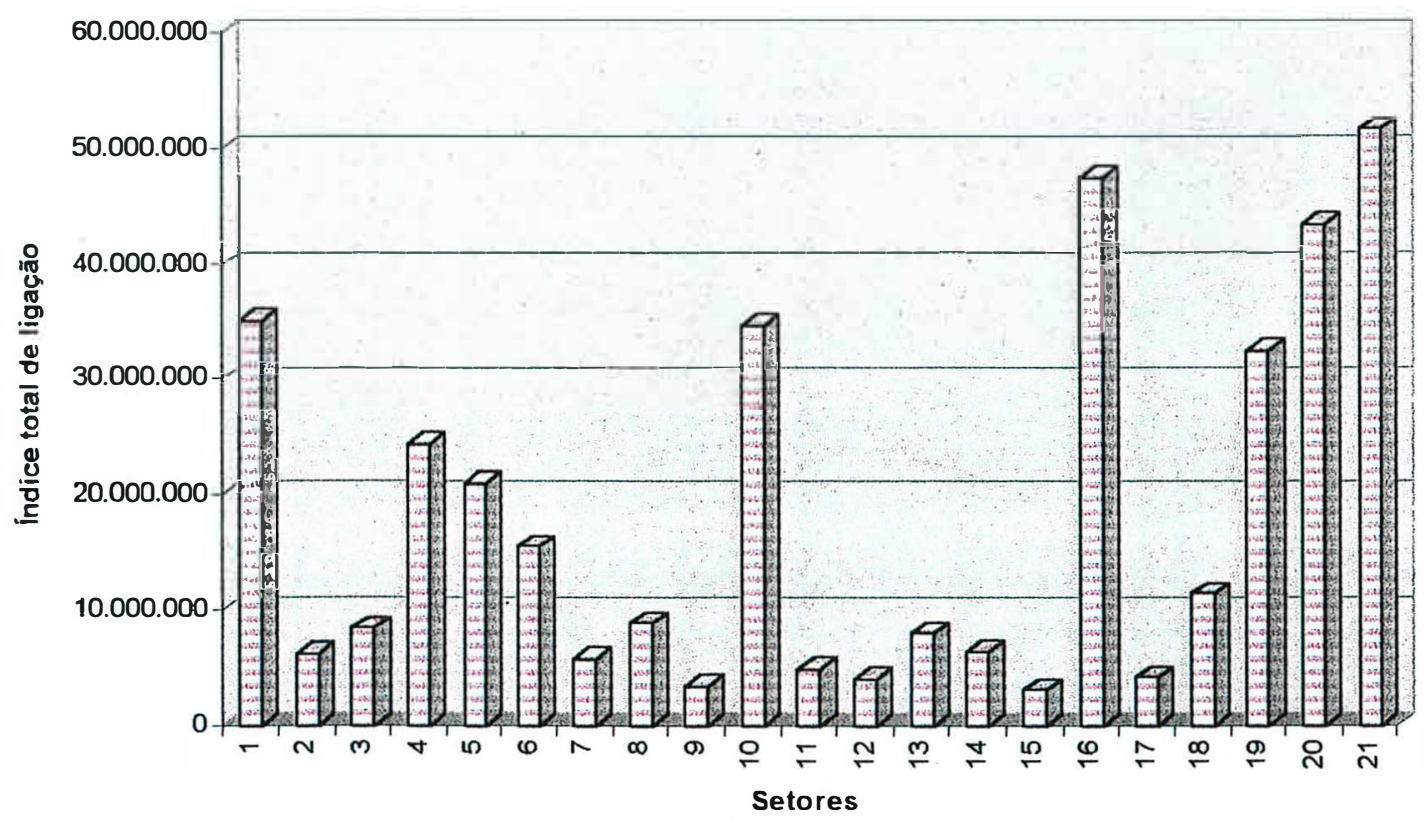

Figura 5.35 - Índice puro - 1994 


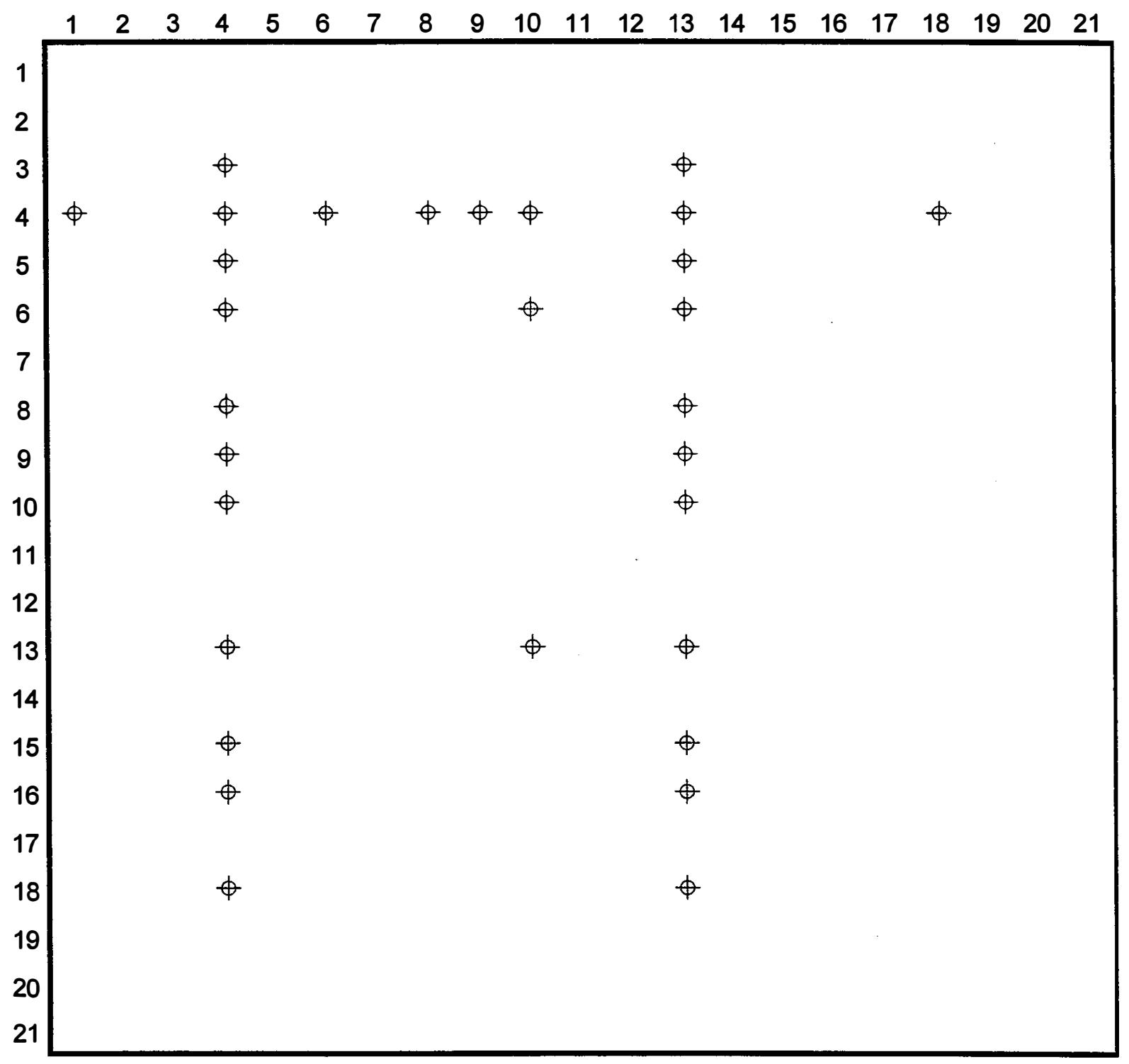

Figura 5.36 - Coeficientes com o maior Campo de Influência - 1990 


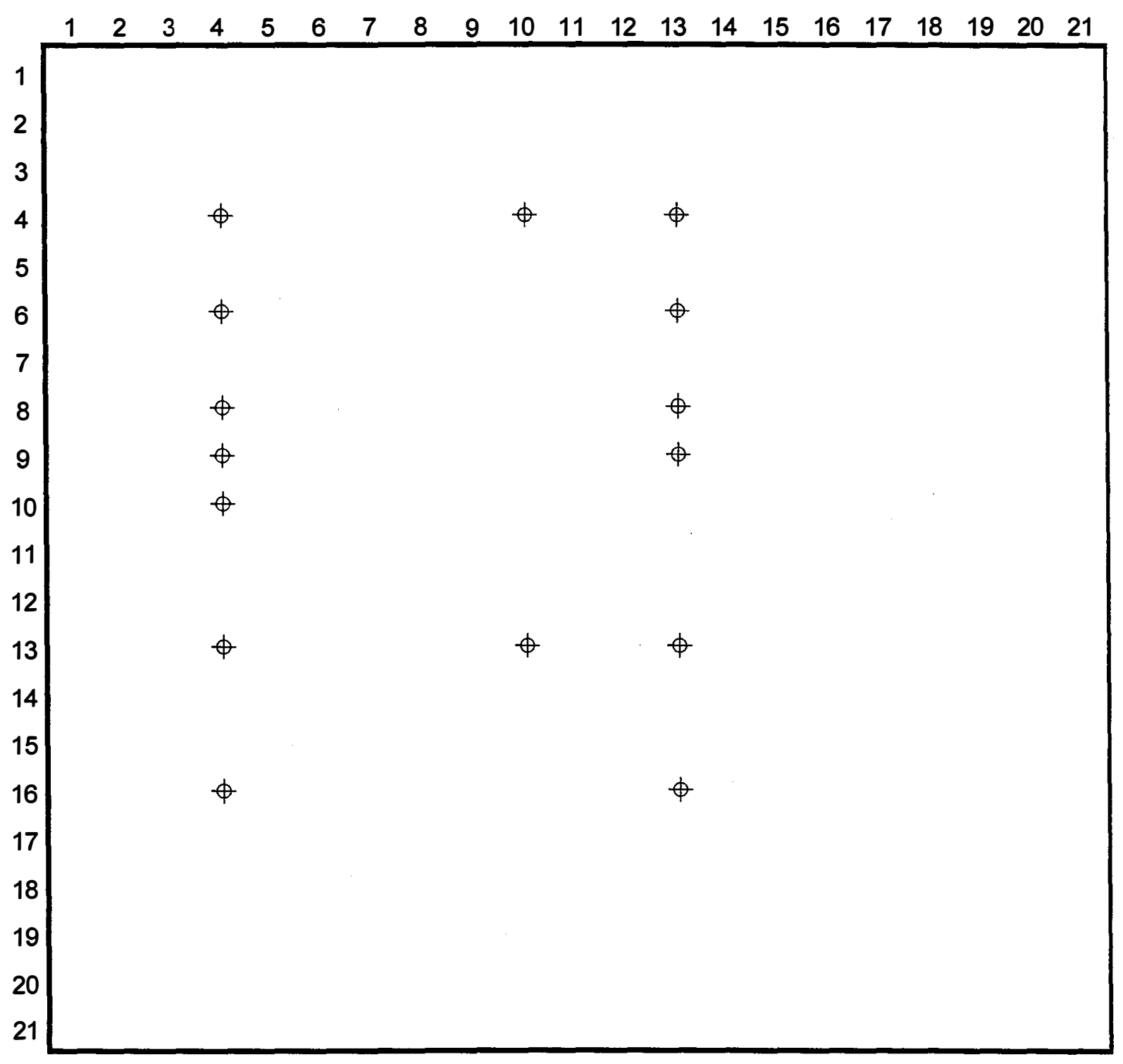

Figura 5.37 - Coeficientes com o maior Campo de Influência - 1991 


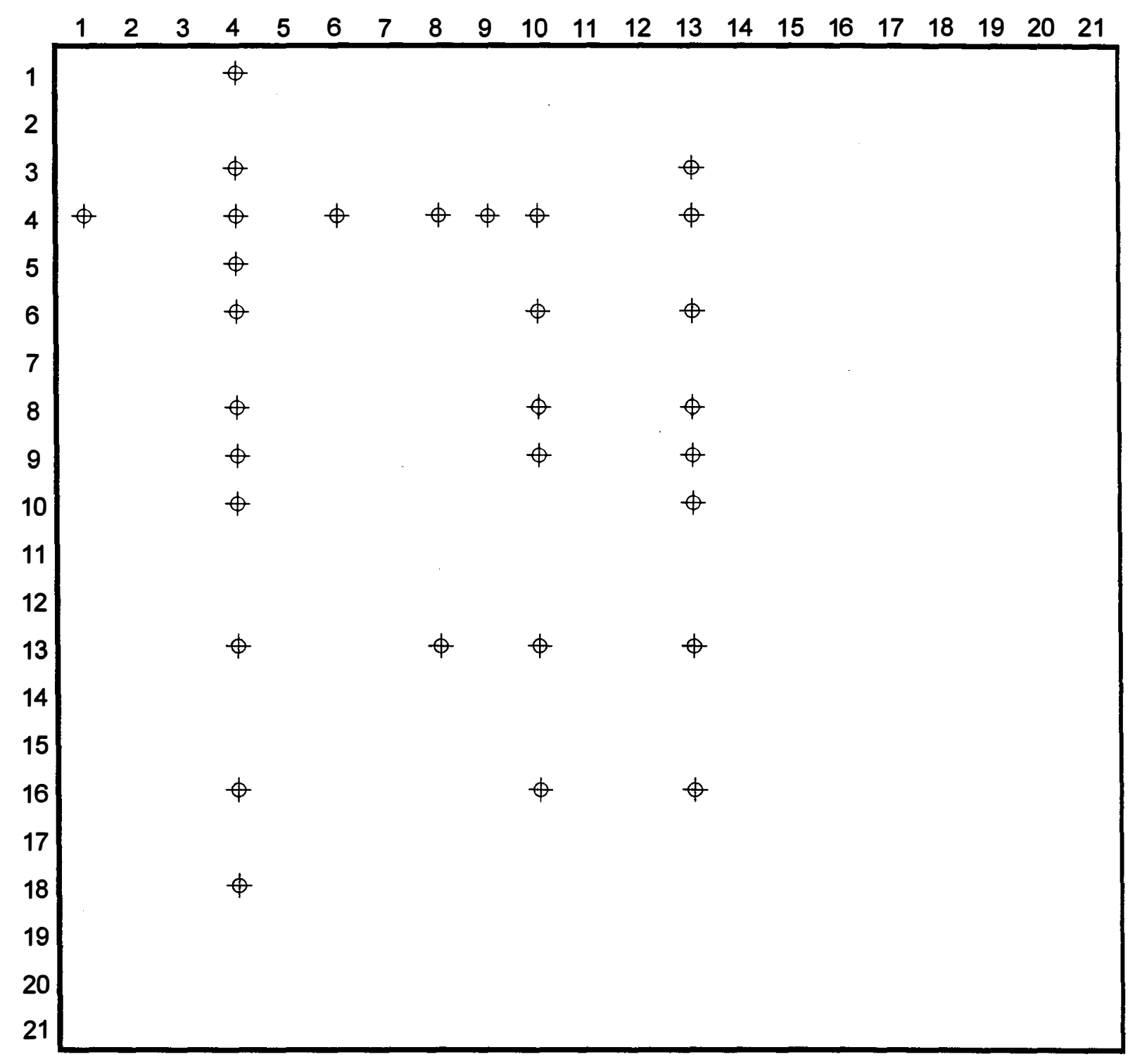

Figura 5.38 - Coeficientes com o maior Campo de Influência - 1992 


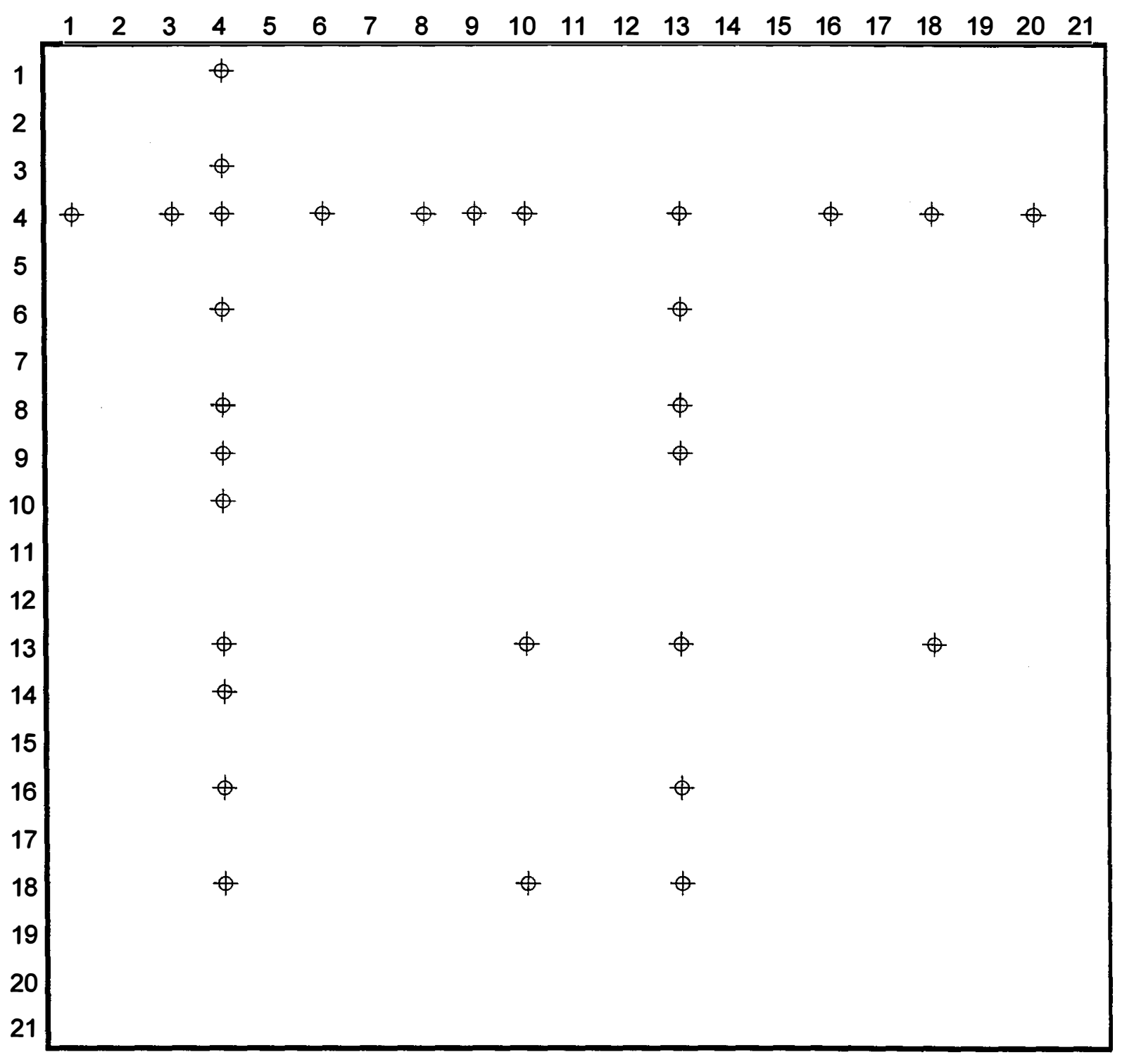

Figura 5.39 - Coeficientes com o maior Campo de Influência - 1993 


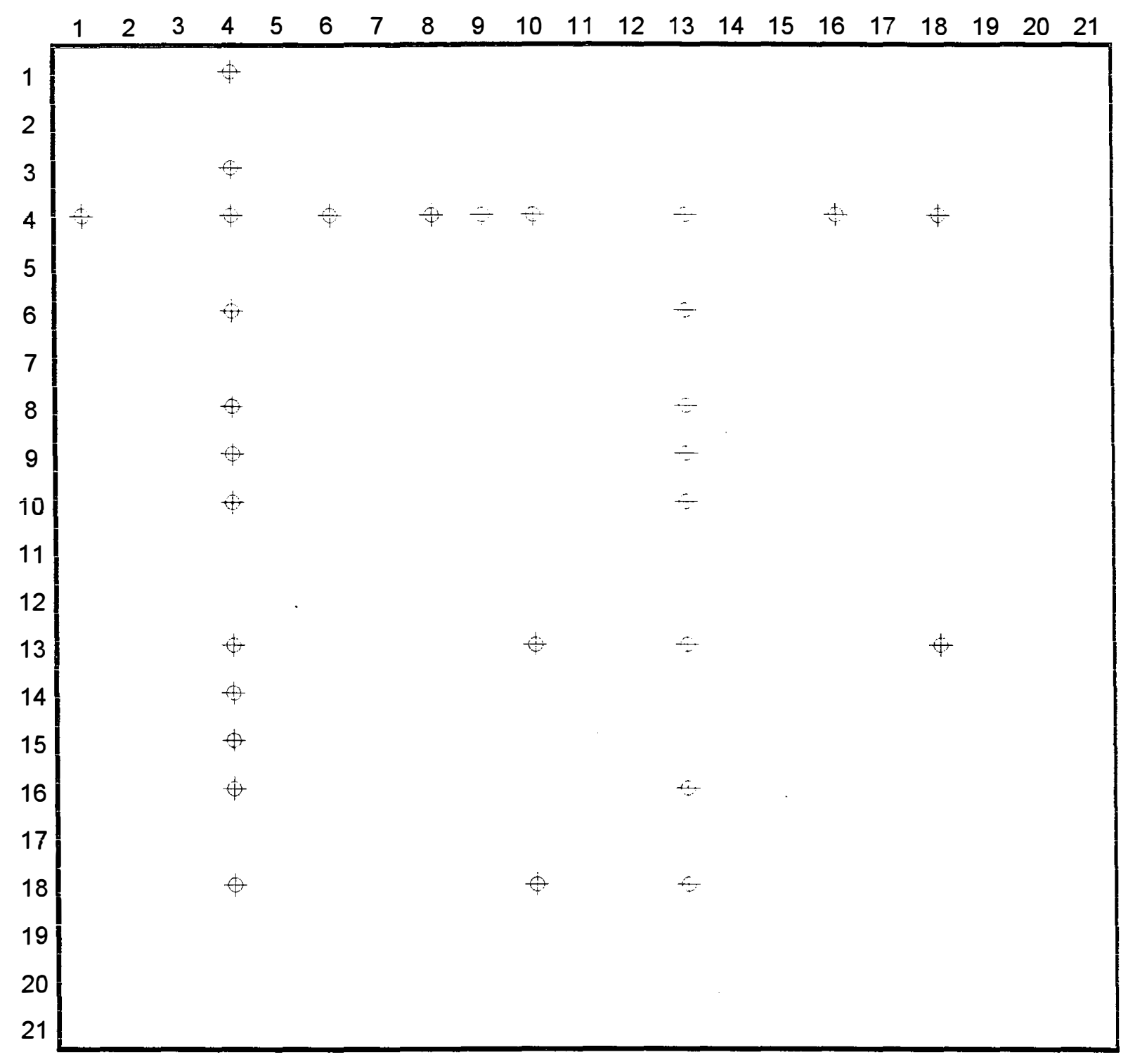

Figura 5.40 - Coeficientes com o maior Campo de Influência - 1994 


\section{CONCLUSÕES}

Uma das tendências mais marcantes do cenário internacional contemporâneo é a formação e consolidação de blocos econômicos, onde os vinculos econômicos de caráter regional acentuam-se. A proliferação e consolidação de blocos econômicos configura, assim, uma nova realidade no cenário das relações internacionais.

Âs relações entre as diversas nações do mundo vão, paulatinamente, cedendo lugar às negociações multilaterais, que substitui a concorrência entre Estados por aquela entre regiões. Nesse contexto, o MERCOSUL não foge a este espirito, assumindo importante papel para os paises participantes desse processo integracionista.

Este trabalho preocupa-se em fazer uma análise da economia brasileira no periodo de transição (1990-1994) para a formação do MERCOSUL. Á relevância da análise numa perspectiva intersetorial è dada pelo crescimento do fluxo de comércio a partir da assinatura do Tratado de Assunção.

No que tange à união aduaneira, quanto mais elevada a tarifa externa comum, maior será o nivel de proteção à produção interna da região integrada e maior a probabilidade de que, num primeiro momento, os preços domésticos sejam mais elevados que os preços internacionais e, portanto, mais elevado o custo para os consumidores e os produtores dentro da região.

Todo o processo de liberalização comercial, intrínseco nos esquemas de integração multinacional de mercados, modifica as condições de competitividade dos produtores nacionais dos paises sócios produzindo alterações nos preços relativos. 
Assim, é que os produtores locais em cada pais podem manifestar-se contrários à integração, temerosos da maior concorrência ou da perda de privilégios que a integração pode significar.

O MERCOSUL è um bloco relativamente pequeno na economia mundial. Desde janeiro de 1995, Argentina, Brasil, Paraguai e Uruguai formam uma união aduaneira imperfeita, com uma série de exceções à tarifa externa comum e mesmo no comércio intra-regional.

A análise dos fluxos de exportação e importação dos paises do MERCOSUL, Chile, Bolivia e Resto do Mundo mostra claramente a elevação do comércio entre os paises do bloco, a partir de 1991, revelando oportunidades de mercado antes ignoradas pelos paises do grupo. O comércio total entre o Brasil e os demais paises do MERCOSUL atingiu o valor de US\$10.579,9 milhões em 1994, o que representa $14 \%$ do comércio total do Brasil. Em 1980, quando o comércio total atingiu o pico da década de 70 , esse valor representava 7\% do comércio total do Brasil. Em termos percentuais, o comércio de 1989 se iguala ao de 1980. Portanto, o resultado de 1994 pode ser entendido como uma mudança na estrutura do comércio exterior brasileiro.

Apesar desse incremento importante do comércio, ainda não estão dadas as condições para uma maior coordenação das politicas cambiais. Contrariamente ao ocorrido na Comunidade Européia e no Acordo de Livre Comércio entre os EUA e o Canadá, o MERCOSUL não é o produto de pressões empresariais para aprofundar vinculos pré-estabelecidos. A vontade política antecede as interdependências no MERCOSUL.

No que se refere aos reflexos do processo integracionista sobre o setor agricola, industrial e de serviços avaliou-se sobre três aspectos: a) estrutura produtiva; b) estrutura da demanda final e c) insumos importados, onde constatou-se que o periodo analisado não mostrou mudanças estruturais relevantes, confirmando a expectativa apresentada nesse trabalho. 
Apesar da implementação do processo integracionista ter provocado um crescimento dos fluxos de comércio entre o Brasil e os demais paises do MERCOSUL, os impactos sobre a estrutura produtiva brasileira e sobre os componentes da demanda final foram pequenos. Os resultados dos multiplicadores setoriais de produção calculados nesta pesquisa evidenciam a importância dos setores 6 - Material de Transporte; 4 - Metalurgia; 16 - Produtos Alimentares para a economia brasileira antes e depois da formação do MERCOSUL. Em 1994 o setor 8 - Papel e Papelão aparece entre os mais importantes.

Levando-se em consideração os resultados dos multiplicadores setoriais de produtos importados da Argentina, Paraguai e Uruguai, esses evidenciam que a partir do MERCOSUL, a economia brasileira diminuiu gradativamente a sua dependência com os paises-membros desse processo de integração. Por outro lado, a demanda final apresentou mudanças significativas, ou seja, o consumo das familias ao longo do periodo analisado se alterou em alguns setores, com a formação do MERCOSUL. Pode-se afirmar que a integração dos paises-membros do MERCOSUL, no periodo analisado, está mais voltada para o comércio de produtos para a demanda final do que para a integração produtiva.

A análise dos indices de ligações formuladas por Rasmussen e Hirschman, revela o grau de integração setorial da economia para um determinado periodo, identificando os setores-chave que a dinamizam tanto pelo grau de demanda por produtos de outros setores, como através do grau de oferta de produtos à outros setores.

A análise dos indices de encadeamento da economia brasileira, para os anos de 1990-1994, através de diferentes técnicas, mostra a predominância dos setores Metalurgia, Material de Transporte, Têxtil e Produtos Alimentares, para o enfoque de Rasmussen e Hirschman, como setores-chave da economia brasileira. Os Produtos Alimentares assumem papel importante no encadeamento para trás. 
O enfoque do campo de influência complementa a análise das ligações de Rasmussen e Hirschman e permite a visualização dos elos mais fortes entre os setores da economia brasileira. O destaque fica para os setores Nietalurgia e Indústria Têxtil, ao longo do periodo analisado. A influência dos setores como Indústria Quimica e Agropecuária é captada pelo enfoque dos indices puros de ligações, análise alternativa que considera o vaior da produção. Os resultados apontam para o crescimento do setor serviços dentro da economia brasileira, seguindo a tendência deste setor em economias desenvolvidas.

De acordo com os resultados obtidos através dos Índices de ligação para trás e para frente. dos índices puros, dos Setores-chave e Campo de influência pode-se reafirmar que a estrutura produtiva apresentou pouca variação a partir de 1991.

Os resultados obtidos evidenciam a necessidade de pesquisar mais sobre os reflexos do MERCOSUL no periodo de transição, pois esses resultados começam a evidenciar pequenas mudanças em 1994. Além disso, considerando ainda as limitações explicitadas no decorrer deste trabalho em relação a utilização do modelo de insumo-produto, cabe ressaltar que as matrizes do IBGE usadas na elaboração do presente estudo no periodo 1990-1994 são matrizes resultantes de atualizações da matriz elaborada pelo IBGE para o ano de 1985.

A presente pesquisa tem contribuições e limitações, mas, constitui o primeiro estudo desta natureza para o Brasil, devendo ser objeto de outros trabalhos no futuro próximo. Á título de sugestões, seriam úteis investigações mais detalhadas sobre os impactos dinâmicos da integração, como os efeitos de economias de escala. Ainda, o trabalho desenvolvido revelou possibilidades de outras análises, entre elas investigações sobre os efeitos diretos na demanda final. A título de sugestão, a análise para identificar que as economias do MERCOSUL passaram a ter uma integração maior na esfera produtiva só após a implantação do Plano Real, enriqueceria as conclusões desta pesquisa. Além disso, pesquisas vindas de outros campos do conhecimento, analisando variáveis politicas, sociais e outras, poderiam ser úteis no sentido de avaliar melhor o projeto de integração MERCOSUL. 


\section{REFERÊNCIAS BIBLIOGRÁFICAS}

BALASSA, B. Teoria da Integração Econômica. Livraria Clássica Editora, Lisboa, 1961.

BAUMANN, R. e LERDA. J.C. Brasil-Argentina-Uruguai. A Integração em Debate. Editora Marco Zero, São Paulo, 1987.

BOLETIM DO DIEESE. Programa de Integração Brasil-Argentina: Reflexos na Agricultura e Agroindústria. São Paulo, DIEESE, v. 9, $n^{\circ} 112$, p. $17-$ 20, julho, 1990.

BOLETIM DO DIEESE. A Economia dos Países do MERCOSUL. Estudos e Pesquisas, número 155, Ano XI - junho de 1992.

BRANCO, A.M. Transporte terrestre e transporte maritimo. In: MERCOSUL: Impasses e Alternativas. Instituto de Estudos Avançados - USP. Série Assuntos Internacionais. São Paulo, 1991.

BRASIL. Câmara dos Deputados. Projeto de Decreto Legislativo n. 87-A de 1991 (da Comissão de Relações Exteriores). Brasilia. 92 p. (mimeo). 1991.

BULMER-THOMAS, V. Input-output analysis in development countries: source, methods and applications. New York, Wiley, 1982, 197 p.

CASTRO, A.B. e Souza, F. E. P. de. A Tarifa Externa Comum e o Setor de Informática. Boletim de Integração Latino-Americana n. 10 - MRE. Setembro de 1993.

CATANIA, M. EI Sector Agropecuário y Agroindustrial en Argentina. Argentina, Centro de Estudios y Promocion Agraria, 1990, $70 \mathrm{p}$.

CELLA, G. The input-output measurement of interindustry linkages. Oxford Bulletin of Economics and Statstics, v. 46, p. 73-84, 1984.

CEPAL -El Tratado de Assunción del Mercado Comum del Cone Sur (MERCOSUR): algumas considerações - LC/R. 1118, enero.

CEPAL. Significación del Mercado Comum en el Desarrollo Económico de América Latina. In: SALGADO, P. Economia de la Integración Latino-americana. Lecturas Seleccionadas. BID. p. 139-154, 1990. 
CEPAL - El tratado de Asunción del Mercado Comum del Cone Sul (Mercosul): algunas consideraciones - LC/R. 1118, enero.

(1992).

CLEMENTS, B.J., ROSSI, J.W. Interindustry linkages and economic development: the case of Brazil reconsidered. The Developing Economies, v.29, p. 166-187, 1991.

DORNBUSCH, R. Los Costos y Benefícios de la Integración Económica Regional. Estudios, ano IV, número 19, Integración Latinoamericana, junho, 1986.

EL-AGRAA, A. International Economic Integration. In: David Guenaway (ed), Current Issues in International Trade, Londres, MacMillan, 1985.

EZCURRA, A. La Nación de Repúblicas: Proyecto Latino-americano del Libertador. Ed. Mist. Relações Exteriores de Venezuela. Caracas, p. $75,1988$.

FONTENELE E SILVA, P. Aspectos Tecnológicos da Estrutura Industrial Brasileira: Uma Análise de Insumo-Produto. Rio de Janeiro, BNDES, 1980. $120 \mathrm{p}$.

FFRENCH - DAVIS, R. "Veinte años de Integración Económica en América Latina: Exitos y Fracassos" In: Integración y Cooperación en América Latina, ed. por Jorge, Antonio y Carrilo, Jorge Salazar, 1982.

FUNDAÇÃO INSTITUTO BRASILEIRO DE GEOGRAFIA E ESTATÍSTICA FIBGE. Matriz de Relações Interindustriais - Brasil, 1975. Rio de Janeiro, 1987. $568 p$.

GUILHOTO, J.J.M. Mudanças Estuturais e Setores-Chaves na Economia Brasileira, 1960-1990. Anais do XIV Encontro Brasileiro de Econometria, Campos do Jordão, v.1, p. 293-310, 1992.

GUILHOTO J.J.M. \& PICERNO, A. E. Estrutura Produtiva, setores-chave e multiplicadores setoriais. Brasil e Uruguai comparados. Revista Brasileira de Economia, Rio de Janeiro, v. 49, n.1, p. 35-61, jan-mar. 1995.

SONIS, M., HEWINGS, G.I.D., MARTINS, E.B. Índices de Ligações e Setores-Chaves na Economia Brasileira: 1959/90. Pesquisa e Planejamento Econômico, Rio de Janeiro, v. 24, n. 2, p. 287-314, ago. de 1994.

HADDAD, P.R. Contabilidade Social e Economia Regional. Rio de Janeiro, Zahar, 1976. $236 \mathrm{p}$. 
HEWINGS, G. J. D. The empirical identification of key sectors in na economy: a regional perspective. The Developing Economies. V. 20, p. 173-195, 1982.

HEWINGS, G. J. D. et al. Key sectors and structural change approaches and their policy implications. Journal of Policy Modeling, v. 11, p. 67-90, 1989.

HIRSCHAMN, A.O. The strategy of economic development. New Haven, Yale University Press, 1958.

HIRST, M. Integração latino-americana: impulso associativo, orientação seletiva. Revista de Comércio Exterior. Rio de Janeiro, 08(30): 17-24, 1992.

IBARRA, D. Nota sobre la Integración Latinoamericana. In EI Trimestre Economico, 58(229), 1991.

JANK, M.S. A importância do setor agroindustrial na integração do cone sul: as cadeias sensiveis. São Paulo: Instituto de Estudos Avançados: 1992. $17 \mathrm{p}$.

LEONTIEF, W. A Economia do Insumo-Produto. São Paulo, Nova Cultura, 1986.

LOPES, M.R. Prioridades para a integração das políticas agrícolas no MERCOSUL: uma avaliação brasileira para servir de referências nas discussões. São Paulo: Instituto de Estudos Avançados, 1992. 37 p.

MACADAR, B. e BELLO, T.S. O Rio Grande do Sul e a integração latinoamericana. A economia gaúcha e os anos 80: uma trajetória regional no contexto da crise brasileira. Coordenador Pedro F.C. de Almeida. Porto Alegre: FEE, 1990, p.646-718.

MACHADO, J.B.M. Integración Económica y Arancel Aduanero Común en el Cono Sur. Integración Latinoamericana, Buenos Aires, INTAL, v. 16, $\mathrm{n}^{\circ}$ 167, p.18-35, 1991.

MACHADO, L.B.M. Harmonização Comercial, Convergência Cambial e Política Industrial no MERCOSUL. Boletim de Integração LatinoAmericana número 11, outubro-dezembro. 1993.

MARQUES, R.L.R. MERCOSUL: origem, evolução e desafios. Conjuntura Econômica, outubro, p.104-107, 1991.

McGILVRAY, J. Linkages, key sectors and development strategy. In: Leontief, W. (ed.). Structure, system and economic policy. Cambridge: Cambridge University Press. 1977. 
MILLER, R.E. \& BLAIR, P.D. Input-Output Analysis: Foundations and Extensions. Englewood Cliffs: Prentice-Hall, 1985.

MONTOYA, M. A. A Distribuição dos Custos e Benefícios da Integração Econômica Regional. In: Análise Econômica, FCE, UFRGS, março, 1993.

PEREIRA, L. V. Tratado de Assunção: Resultados e Perspectivas. In: MERCOSUL: Perspectivas da Integração. Rio de Janeiro. Ed. FGV, 1996. $308 \mathrm{p}$.

PEREZ, J.E.G. A integração Brasil Argentina: um estudo da competitividade na produção de grãos. Porto Alegre: UFRGS, 1988. 122 p. Dissertação (Mestrado) - Universidade Federal do Rio Grande do Sul, 1988.

QUIJANO, J.M. Uruguay en el mercado comum. Que Hacer? Integración Latinoamericana, número 167, Buenos Aires: INTAL, maio de 1991, p. 4656.

RASMUSSEN, P. Studies Intersectorial (relations - Amsterdam, North Holland, 1956).

REGO, E. C. L. O processo de constituição do MERCOSUL. Rio de Janeiro: BNDES, 1995. 28 p.

RICARDO, D. Princípios de Economia Política e Tributação. São Paulo: Nova Cultural, 1985 (Série Os Economistas). (1ª edição inglesa, 1817).

RODRIGUEZ, O. Teoria do Subdesenvolvimento da CEPAL. Editora Forense Universitária, Rio de Janeiro, 1981.

SALGADO, G. El mercado regional latinoamericano: el proyecto y la realidad. Revista de la CEPAL. Santiago do Chile, n. 7, p. 87-133. Abr. 1979.

SALGADO, G. Los padrones de uma integración viable y sus Modalidades. In: Salgado, G. Economia de la integración Latino Americana. INTAL, p. 159-184, 1990.

SALGADO, G. Motivaciones y Requisitos de la Integración Económia entre Paises en desarrollo, particularmente Latino Americanos. In: SALGADO, P. Económia de la Integración Latino Americana: Lecturas seleccionadas. BID, p. 115-121, 1990.

SILVA, G.J. - Antecedentes históricos do processo de integração americana: ALALC, MCCA, Pacto Andino. Tema de integração latino latino-americana. Coordenador Seintenfus e Boni, Rio de Janeiro, Vozes, 1990. p.32-8I. 
SMITH, A. An Inquiry into the Nature and Causes of the Wealth of Nations. London, 1776.

SONIS, M., HEWINGS, G.I.D. Fields of Influence in Input-Output Systems. Manuscrito não-publicado. Regional Economics Application Laboratory University of Illinois al Urbana, Champaign, 1994.

STULP, V.J. Tecnologia, custos e competitividade no Mercosul: caso do trigo, soja, milho e arroz. São Paulo: Instituto de Estudos Avançados, 1992. $23 \mathrm{p}$.

TEIXEIRA, S.M. Cenários no mercado agrícola internacional. Revista de Economia e Sociologia Rural. Brasília, volume 31, número 1, p. 45-64, 1991.

THORSTENSEN et allii. O Brasil Frente a um Mundo Dividido em Blocos. Livraria Nobel. São Paulo, 1994.

THOUMI, F.E. "Bilateral Trade Flows and Economic Integration in Latin America and the Caribbean". World Develop, March, 17(3), p. 421-29, 1989.

VEIGA, P.M. Cone Sul: a economia política da integração. Rio de Janeiro: Fundação Centro de Estudos do Comércio Exterior, 1991. 209 p.

VEIGA, P.M. Abertura Externa e Integração do MERCOSUL: cenários para o período de transição. Revista Brasileira de Comércio Exterior, número 32, julho/agosto/setembro, 1992.

VERSIANI, F.R. A Experiência Latino-Americana de Integração e os Novos Acordos Brasil-Argentina-Uruguai. In: Baumann e Lerda, 1987.

VINER, J. “The Customs Union Theory". N.Y. Carnegie Endowment for International Peace. 1950.

WILLIANSON, J. A Economia Aberta e a Economia Mundial. Um Texto de Economia Internacional. Editora Campus. Rio de Janeiro, 1989.

WONNACOTT, P. e Wonnacott, R. Is Unilateral Tariff Reduction Preferable to a Custons Union? The Curious Case of the Missing Foreign Tariff. American Economic Review, septembre, 1981. In: Dornbusch, 1986. 
APÊNDICES 


\section{APÊNDICE A}

\section{SIGLAS}

CEPAL - Comissão Econômica para a América Latina.

ALALC - Associação Latino-Americana de Livre Comércio.

MCCA - Mercado Comum Centro-Americano.

PMDR - Países de Menor Desenvolvimento Relativo.

GATT - General Agreement on Tariffs and trade.

ALADI - Associação Latino-Americana de Integração.

FMI - Fundo Monetário Internacional.

CECLA - Comissão Especial de Coordenação Latino-Americana.

INTAL - Instituto para Integração da América Latina.

GRULA - Grupo de Embaixadores Latino-Americanos.

SELA - Sistema Econômico Latino-Americano.

CARIFTA - Caribbean Free Trade Association.

CARICOM - Mercado Comum do Caribe.

CAUCE - Acordo de Cooperação Técnica.

PEC - Protocolo de Expansão Comercial.

PAR - Preferência Alfandegária Regional.

MERCOSUL - Mercado Comum do Sul

ACE - Acordos de Complementação Econômica.

NAFTA - Acordo de Livre Comércio da América do Norte.

TEC - Tarifa Externa Comum.

ALCA - Área de Livre Comércio da América do Norte.

ALCSA - Área de Livre Comércio Sul-Americana.

OMC - Organização Mundial do Comércio. 


\section{APÊNDICE B}

\section{BLOCOS ECONÔMICOS}

a) Bloco Europeu: UE - União Européia (Alemanha, França, Reino Unido, Itália, Bélgica, Holanda, Luxemburgo, Dinamarca, Irlanda, Grécia, Espanha e Portugal) e EFTA - Europen Free Trade Association (Noruega, Suécia, Finlândia, Islândia, Austria "Liechtenstein" e Suiça);

b) Bloco da América do Norte: EUA, Canadá e México;

c) Bloco Asiático: Japão, China, NICs (Coréia do Sul, Formosa, Cingapura e Hongcong), ASEAN (Tailândia, Indonésia, Malásia e Filipinas);

d) Bloco América do Sul: países da América do Sul (todos da América do Sul excluindo o MERCOSUL);

e) Bloco MERCOSUL: Brasil, Argentina, Uruguai e Paraguai;

f) Bloco Resto do Mundo: demais países. 


\section{APÊNDICE C}

Procedimentos metodológicos para a compatibilização e agregação dos dados do IBGE e da SECEX - MICT. 
Tabela C1 - Agregação IBGE (1990-1995) pela Matriz IBGE de 1985

\begin{tabular}{|l|l|}
\hline \multicolumn{1}{|c|}{ Setor } & \multicolumn{1}{|c|}{ Classificação } \\
\hline 1. Agropecuária & 01 \\
\hline 2. Mineração & 02 e 03 \\
\hline 3. Minerais n-Metálicos & 04 \\
\hline 4. Metalurgia & $05,06,07$ \\
\hline 5. Mecânica e M.Elétrico & 08,10 e 11 \\
\hline 6. Mat. de Transporte & 12 e 13 \\
\hline 7. Madeira e Mobiliário & 14 \\
\hline 8. Papel e Papelão & 15 \\
\hline 9. Borracha & 16 \\
\hline 10.Ind.Química & 17,18 e 19 \\
\hline 11.Ind.Farmacêutica & 20 \\
\hline 12.Plásticos & 21 \\
\hline 13. Ind. Têxtil & 22 \\
\hline 14. Vestuário & 23 \\
\hline 15. Calçados e Couros & 24 \\
\hline 16. Prod. Alimentares & $25,26,27,28,29,30$ e 31 \\
\hline 17. Diversos & 32 \\
\hline 18. Ser.Ind. de U.P. & 33 \\
\hline 19. Construção Civil & 34 \\
\hline 20. Transp. e M.Com. & 35 e 36 \\
\hline 21. Serviços & $37,38,39,40,41,42$ e 43 \\
\hline
\end{tabular}


Tabela C2 - Secretaria do Comércio Exterior (dados agregados)

\begin{tabular}{|l|l|}
\hline \multicolumn{1}{|c|}{ Setor } & \multicolumn{1}{c|}{ CLASSIFICAÇÃO - NBM (CAPÍTULO) } \\
\hline 1. Agropecuária & $01-14$ \\
\hline 2. Mineração & 27 \\
\hline 3. Minerais n-Metálicos & $26,68,69$ e 70 \\
\hline 4. Metalurgia & $71-83$ \\
\hline 5. Mecânica e M.Elétrico & 84,85 e $90-92$ \\
\hline 6. Mat. de Transporte & $86-89$ \\
\hline 7. Madeira e Mobiliário & $44-49$ e 94 \\
\hline 8. Papel e Papelão & 48 e 49 \\
\hline 9. Borracha & 40 \\
\hline 10.Ind.Química & $28-38$ \\
\hline 11.Ind. Farmacêutica & 30 e 33 \\
\hline 12.Plásticos & 39 \\
\hline 13. Ind. Têxtil & $50-60$ \\
\hline 14. Vestuário & $61-63$ e $65-67$ \\
\hline 15. Calçados e Couros & $41-43$ e 64 \\
\hline 16. Prod. Alimentares & $15-25$ \\
\hline 17. Diversos & $93,95-98$ \\
\hline
\end{tabular}




\section{- Agregação dos setores e produtos nas tabelas básicas}

A partir das tabelas básicas (matriz de produção - Brasil 1990-1994 e matriz de insumo das atividades e demanda final - Brasil 1990-1994) do IBGE, com base na nomenclatura de Miller e Blair (1985), procedemos as agregações, resultando em duas matrizes, "V" e "U", denominadas de matriz de produção e de uso, respectivamente, ambas com dimensão $21 \times 21$. Utilizamos a notação " $m$ " para produtos e " $n$ " para setores da economia.

A matriz $V=\left[v_{i j}\right]$ é a matriz de produção e $v_{i j}$ representa a quantia do produto "i" produzida pelo setor "j", sendo que $V$ tem dimensão $n \times m$.

A matriz $U=\left[u_{i j}\right]$ é a matriz de uso e $u_{i j}$ representa a quantia de produto "i" usada pelo setor "j", onde $U$ tem dimensão $m \times n$.

\section{- Construção das matrizes "U" e "V"}

A agregação dos setores se deu em duas etapas em cada uma das tabelas básicas, com dimensão $42 \times 80$ e $80 \times 42$, respectivamente.

etapa 1 - procedemos a agregação nas tabelas básicas das linhas, criando alguns setores, originando desta forma das matrizes " $V$ " e " $U$ ", ambas com dimensão $21 \times 80$.

etapa 2 - em seguida, a partir das matrizes "V" e "U", ambas com dimensão 21 x 80 , agregamos as colunas, construindo finalmente as matrizes " $\mathrm{V}$ " e " $U$ ", ambas com dimensão $21 \times 21$.

Obtivemos, na verdade, agregação de setores e produtos. 


\section{APÊNDICE D}

Tabelas apresentando dados de exportações por países no período 1990-1996 em US\$ milhões FOB.

Tabelas apresentando dados de importações por países no período 1990-1996 em US\$ milhões FOB.

Tabelas de participações e distribuições setoriais. 
D1

Exportaçōes Brasileiras para o Mercosul, Chile e Bolivia - 1990 - US\$ milhōes (FOB)

\begin{tabular}{|c|c|c|c|c|c|c|c|c|}
\hline & Argentina & Paraguai & Uruguai & Chile & Bolivia & Total & R. Mundo & Total \\
\hline 1 Agropecuária & 26.872 & 1.036 & 24.938 & 9.494 & 1.012 & 63.352 & 420.016 & 483.368 \\
\hline 2 Mineração & 7.607 & 20.772 & 3.062 & 246 & 117 & 31.804 & 596.477 & 628.28 \\
\hline 3 Minerais não Metälicos & 111.419 & 20.731 & 3.770 & 9.408 & 9.035 & 154.363 & 2.501 .847 & 2.656 .210 \\
\hline 4 Metalurgia & 155.056 & 72.809 & 56.178 & 154.878 & 49.447 & 488.368 & 5.743 .126 & 6.231 .494 \\
\hline 5 Mecânica e Material Elétrico & 39.465 & 25.376 & 31.933 & 49.766 & 19.615 & 166.155 & 856.832 & 1.022 .987 \\
\hline 6 Material de Transporte & 65.497 & 35.780 & 62.076 & 341 & 14.799 & 178.493 & 1.433 .000 & 1.611 .49 \\
\hline 7 Madeira e Mobiliário & 3.737 & 1.539 & 5.183 & 1.184 & 1.625 & 13.268 & 49.560 & 62.828 \\
\hline 8 Papel e Papelão & 16.053 & 11.648 & 7.131 & 21.530 & 7.672 & 64.034 & 549.408 & 613.442 \\
\hline 9 Borracha & 13.568 & 33.602 & 5.593 & 15.296 & 4.743 & 72.802 & 233.772 & 306.574 \\
\hline 10 Indústria Quimica & 134.782 & 26.765 & 30.433 & 34.147 & 11.919 & 238.046 & 769.906 & 1.007 .952 \\
\hline 11 Indústria Farmacêutica & 1.765 & 10.935 & 6.792 & 1.581 & 491 & 21.564 & 543.889 & 565.453 \\
\hline 12 Plásticos & 25.934 & 13.638 & 31.684 & 25.330 & 9.283 & 105.869 & 391.952 & 497.821 \\
\hline 13 Indústria Têxtil & 11.642 & 20.903 & 10.563 & 21.086 & 9.416 & 73.610 & 5.580 .922 & 5.654 .532 \\
\hline 14 Vestuário & 322 & 28.870 & 1.033 & 4.942 & 11.235 & 46.402 & 2.766 .723 & 2.813.125 \\
\hline 15 Calçados e Couros & 161 & 9.665 & 5.519 & 513 & 13.229 & 29.087 & 420.949 & 450.03 \\
\hline 16 Produtos Alimentares & 28.269 & 43.544 & 7.075 & 14.505 & 13.033 & 106.426 & 6.576.388 & 6.682 .814 \\
\hline 17 Diversos & 3.007 & 2.883 & 1.673 & 5.650 & 5.595 & 18.808 & 106.848 & 125.656 \\
\hline 18 Serviços Industriais de U.P. & 0 & 0 & 0 & 0 & 0 & 0 & 0 & \\
\hline 19 Construção Civil & 0 & 0 & 0 & 0 & 0 & 0 & 0 & \\
\hline 20 Transporte e M. Comércio & 0 & 0 & 0 & 0 & 0 & 0 & 0 & \\
\hline 21 Serviços & 0 & 0 & 0 & 0 & 0 & 0 & 0 & \\
\hline Total & 646.248 & 384.700 & 299.094 & 369.568 & 179.309 & 1.878 .919 & 29.535.149 & 31.414 .068 \\
\hline
\end{tabular}

D2

Exportações Brasileiras para o Mercosul, Chile e Bolivia - 1991 - US\$ milhōes (FOB)

\begin{tabular}{|c|c|c|c|c|c|c|c|c|}
\hline & Argentina & Paraguai & Uruguai & Chile & Bolivia & Total & R. Mundo & Total \\
\hline 1 Agropecuária & 68.903 & 2.556 & 27.385 & 14.023 & 1.774 & 114.641 & 531.262 & 645.903 \\
\hline 2 Mineraçāo & 7.975 & 20.599 & 351 & 5.559 & 402 & 34.886 & $\mathbf{5 9 7 . 5 1 4}$ & 632.400 \\
\hline 3 Minerais não Metálicos & 111.419 & 20.731 & 3.770 & 9.408 & 9.035 & 154.363 & 2.501 .847 & 2.656.210 \\
\hline 4 Metalurgia & 372.973 & 106.444 & 65.893 & 203.587 & 81.040 & 829.937 & 6.083 .785 & 6.913 .722 \\
\hline 5 Mecânica e Material Elétrico & 90.776 & 31.645 & 20.195 & 39.961 & 20.525 & 203.102 & 811.734 & 1.014 .836 \\
\hline 6 Material de Transporte & 261.059 & 34.505 & 77.894 & 187.468 & 23.539 & 584.465 & 1.040 .505 & 1.624 .970 \\
\hline 7 Madeira e Mobiliário & 15.043 & 1.388 & 6.479 & 1.216 & 2.069 & 26.195 & 263.561 & 289.756 \\
\hline 8 Papel e Papelāo & 79.619 & 14.080 & 13.949 & 30.531 & 11.834 & 150.013 & 507.458 & 657.471 \\
\hline 9 Borracha & 56.584 & 37.624 & 7.899 & 19.100 & 6.460 & 127.667 & 232.638 & 360.305 \\
\hline 10 Indústria Química & 164.512 & 37.908 & 33.016 & 45.108 & 19.261 & 299.805 & 658.057 & 957.862 \\
\hline 11 Indústria Farmacêutica & 3.935 & 13.593 & 9.764 & 3.224 & 866 & 31.382 & 63.478 & 94.860 \\
\hline 12 Plásticos & 75.160 & 17.323 & 31.458 & 33.009 & 9.897 & 166.847 & 363.952 & 530.799 \\
\hline 13 Indústria Têxtil & 50.625 & 20.285 & 15.649 & 35.761 & 14.461 & 136.781 & 5.554 .819 & 5.091 .600 \\
\hline 14 Vestuário & 17.277 & 41.834 & 4.254 & 7.210 & 14.419 & 84.994 & 2.444 .606 & 2.529 .600 \\
\hline 15 Calçados e Couros & 3.373 & 15.114 & 6.707 & 2.178 & 10.580 & 37.952 & 657.688 & 695.640 \\
\hline 16 Produtos Alimentares & 61.294 & 74.595 & 11.198 & 29.262 & 20.035 & 196.384 & 6.127.751 & 6.091 .390 \\
\hline 17 Diversos & 35.643 & 5.890 & 1.207 & 10.648 & 9.758 & 63.146 & 169.599 & 232.745 \\
\hline 18 Serviços Industriais de U.P. & 0 & 0 & 0 & 0 & 0 & 0 & 0 & 0 \\
\hline 19 Construçāo Civil & 0 & 0 & 0 & 0 & 0 & 0 & 0 & 0 \\
\hline 20 Transporte e M. Comércio & 0 & 0 & 0 & 0 & 0 & 0 & 0 & 0 \\
\hline 21 Serviços & 0 & 0 & 0 & 0 & 0 & 0 & 0 & 0 \\
\hline Total & 1.452 .779 & 499.256 & 338.476 & 674.021 & 249.870 & 3.214 .402 & 28.405 .667 & 31.020 .069 \\
\hline
\end{tabular}


D3

Exportações Brasileiras para o Mercosul, Chile e Bolívia - 1992 - US\$ milhões (FOB)

\begin{tabular}{|c|c|c|c|c|c|c|c|c|}
\hline & Argentina & Paraguai & Uruguai & Chile & Bolivia & Total & R. Mundo & Total \\
\hline 1 Agropecuária & 158.625 & 4.301 & 39.175 & 14.735 & 1.865 & 218.701 & 3.076.859 & 3.295 .560 \\
\hline 2 Mineração & 20.873 & 23.387 & 9.258 & 1.799 & 702 & 56.019 & 471.962 & 527.981 \\
\hline 3 Minerais não Metálicos & 123.025 & 24.294 & 6.923 & 21.030 & 12.666 & 187.938 & 2.742 .948 & 2.930 .886 \\
\hline 4 Metalurgia & 791.328 & 116.990 & 105.087 & 275.813 & 111.542 & 1.400 .760 & 7.820 .658 & 9.221 .418 \\
\hline 5 Mecânica e Material Elétrico & 166.813 & 30.121 & 27.333 & 46.850 & 24.427 & 295.544 & 1.067 .869 & 1.363 .413 \\
\hline 6 Material de Transporte & 882.995 & 35.355 & 172 & 286.242 & 33.507 & 1.238.271 & 2.201 .869 & 3.440 .140 \\
\hline 7 Madeira e Mobiliário & 40.072 & 2.082 & 11.565 & 1.863 & 2.605 & 58.187 & 1.392 .361 & 1.450 .548 \\
\hline 8 Papel e Papelāo & 125.898 & 16.076 & 19.084 & 35.726 & 13.479 & 210.263 & 526.854 & 737.117 \\
\hline 9 Borracha & 84.876 & 39.912 & 10.939 & 26.152 & 9.469 & 171.348 & 300.224 & 471.572 \\
\hline 10 Indústria Química & 231.342 & 44.403 & 34.622 & 57.164 & 23.625 & 391.156 & 1.159 .827 & 1.550 .983 \\
\hline 11 Indústria Farmacêutica & 12.098 & 9.124 & 3.129 & 3.419 & 6.051 & 33.821 & 112.948 & 146.769 \\
\hline 12 Plásticos & 117.543 & 18.112 & 33.665 & 43.535 & 11.970 & 224.825 & 375.704 & 600.529 \\
\hline 13 Indústria Têxtil & 92.497 & 18.848 & 20.794 & 50.632 & 22.075 & 204.846 & 687.397 & 892.243 \\
\hline 14 Vestuário & 52.004 & 39.957 & 10.064 & 11.456 & 17.975 & 131.456 & 445.671 & 577.127 \\
\hline 15 Calçados e Couros & 14.143 & 14.453 & 6.690 & 9.493 & 10.354 & 55.133 & 1.857.223 & 1.912 .356 \\
\hline 16 Produtos Alimentares & 106.679 & 97.627 & 16.065 & 29.638 & 26.422 & 276.431 & 5.824 .949 & 6.101 .380 \\
\hline 17 Diversos & 19.167 & 8.267 & 3.863 & 7.968 & 3.896 & 43.161 & 529.793 & 572.954 \\
\hline 18 Serviços Industriais de U.P. & 0 & 0 & 0 & 0 & 0 & 0 & 0 & 0 \\
\hline 19 Construção Civil & 0 & 0 & 0 & 0 & 0 & 0 & 0 & 0 \\
\hline 20 Transporte e M. Comércio & 0 & 0 & 0 & 0 & 0 & 0 & 0 & 0 \\
\hline 21 Serviços & 0 & 0 & 0 & 0 & 0 & 0 & 0 & 0 \\
\hline Total & 3.039 .978 & 543.309 & 358.428 & 923.515 & 332.630 & 5.197 .860 & 30.595 .116 & 35.792 .976 \\
\hline
\end{tabular}

D4

Exportaçōes Brasileiras para o Mercosul, Chile e Bolívia - 1993 - US\$ milhões (FOB)

\begin{tabular}{|c|c|c|c|c|c|c|c|c|}
\hline & Argentina & Paraguai & Unuguai & Chile & Bolivia & Total & R. Mundo & Total \\
\hline 1 Agropecuária & 182.974 & 5.279 & 53.486 & 17.161 & 1.860 & 260.760 & 3.457 .458 & 3.718 .218 \\
\hline 2 Mineração & 75.180 & 31.401 & 62.898 & 1.000 & 3.221 & 173.700 & 472.181 & 645.881 \\
\hline 3 Minerais não Metálicos & 161.306 & 37.103 & 12.875 & 28.325 & 17.268 & 256.877 & 2.748 .440 & 3.005.317 \\
\hline 4 Metalurgia & 911.936 & 199.636 & 148.782 & 378.686 & 135.837 & 1.774 .877 & 8.060 .312 & 9.835 .189 \\
\hline 5 Mecânica e Material Elétrico & 226.470 & 52.382 & 43.362 & 58.642 & 29.942 & 410.798 & 1.158 .122 & 1.568 .920 \\
\hline 6 Material de Transporte & 910.311 & 66.999 & 198.454 & 312.753 & 32.095 & 1.520 .612 & 1.912.079 & 3.432 .691 \\
\hline 7 Madeira e Mobiliário & 68.779 & 3.778 & 24.449 & 4.457 & 3.897 & 105.360 & 1.720 .864 & 1.826 .224 \\
\hline 8 Papel e Papelão & 193.876 & 30.966 & 26.082 & 38.011 & 15.574 & 304.509 & 538.586 & 843.095 \\
\hline 9 Borracha & 80.831 & 77.710 & 11.853 & 34.817 & 15.218 & 220.429 & 313.063 & 533.492 \\
\hline 10 Indústria Química & 306.094 & 92.190 & 41.292 & 53.476 & 29.314 & 522.366 & 1.187 .012 & 1.709 .378 \\
\hline 11 Indústria Farmacêutica & 17.752 & 15.145 & 3.861 & 5.701 & 8.616 & 51.075 & 117.393 & 168.468 \\
\hline 12 Plásticos & 176.814 & 29.671 & 42.681 & 50.832 & 19.403 & 319.401 & 386.710 & 706.111 \\
\hline 13 Indústria Têxtil & 110.077 & 34.351 & 30.240 & 52.050 & 31.796 & 258.514 & 454.510 & 713.024 \\
\hline 14 Vestuário & 48.506 & 60.135 & 26.823 & 14.024 & 30.349 & 179.837 & 497.741 & 677.578 \\
\hline 15 Calçados e Couros & 11.900 & 32.812 & 8.581 & 13.837 & 14.130 & 81.260 & 2.302 .423 & 2.383 .683 \\
\hline 16 Produtos Alimentares & 144.929 & 167.772 & 34.360 & 30.514 & 35.539 & 413.114 & 5.951 .935 & 6.365 .049 \\
\hline 17 Diversos & 31.038 & 14.984 & 5.727 & 14.045 & 6.589 & 72.383 & 350.067 & 422.450 \\
\hline 18 Serviços Industriais de U.P. & 0 & 0 & 0 & 0 & 0 & 0 & 0 & 0 \\
\hline 19 Construção Civil & 0 & 0 & 0 & 0 & 0 & 0 & 0 & 0 \\
\hline 20 Transporte e M. Comércio & 0 & 0 & 0 & 0 & 0 & 0 & 0 & 0 \\
\hline 21 Serviços & 0 & 0 & 0 & 0 & 0 & 0 & 0 & 0 \\
\hline Total & 3.658 .773 & 952.314 & 775.806 & 1.108 .331 & 430.648 & 6.925 .872 & 31.628 .896 & 38.554 .768 \\
\hline
\end{tabular}


D5

Exportações Brasileiras para o Mercosul, Chile e Bolivia - 1994 - US\$ milhōes (FOB)

\begin{tabular}{|c|c|c|c|c|c|c|c|c|}
\hline & Argentina & Paraguai & Uruguai & Chile & Bolivia & Total & R. Mundo & Total \\
\hline $1 \mathrm{Ag}$ & 168 & 9.216 & 54.815 & 27.368 & 3.536 & 202 & .777 & 5.226 .979 \\
\hline 2 Min & 92.152 & 33.417 & 87.190 & 1.058 & 1.666 & 215.483 & 576.500 & 791.983 \\
\hline ais não Metálicos & 164.244 & 35.141 & 15.991 & 21.466 & 18.290 & 255.132 & 2.816 .534 & 3.071 .666 \\
\hline 4 Met & 1.066 .756 & 217.055 & 122.104 & 303.983 & 141.668 & 1.851 .566 & 313 & 10.433 .879 \\
\hline 5 Mec & 244.255 & 60.007 & 54.391 & 53.823 & 29.187 & 441.663 & 1.241 .263 & 1.682 .926 \\
\hline 6 Mat & 1.00 & 91.757 & 142.184 & 260.528 & 45.577 & 1.540 .271 & 719 & 3.805 .990 \\
\hline $7 M$ & 85.519 & 4.805 & 29.619 & 3.673 & 4.765 & 128.381 & 566 & 2.211 .947 \\
\hline $8 F$ & 170.327 & 28.168 & 25.300 & 44.920 & 19.026 & .741 & 384 & 974.425 \\
\hline $9 \mathrm{~B}$ & 131 & 97.944 & 12 & 25.998 & 21.823 & 252.812 & 554 & 602.866 \\
\hline $10 \mathrm{Ir}$ & 383.605 & 102.778 & 37.029 & 58.626 & 33.817 & 615.855 & 296 & 1.862 .151 \\
\hline 11 I & 596 & 12.993 & 5.355 & 9.021 & 8.827 & 61.792 & 957 & 191.749 \\
\hline $12 F$ & 205.047 & 36.024 & 50.917 & 55.322 & 27.036 & 374.346 & 210 & 556 \\
\hline 13 & 32 & & & 43.786 & 32.622 & 341 & 19 & \\
\hline $14 \mathrm{~V}$ & 65.444 & 41.016 & 17.115 & 12.236 & 27.060 & 162.871 & 453.130 & 616.001 \\
\hline $15 \mathrm{C}$ & 18.927 & 28.965 & 7.683 & 16.253 & 15.588 & 87.416 & 859 & 2.133 .275 \\
\hline tos Alimentares & 211.918 & 200.138 & 37.292 & 50.443 & 33.857 & 533.648 & .816 & 7.721 .464 \\
\hline 17 [ & 28.211 & 18.057 & 6.309 & 10.309 & 5.747 & 68.633 & 573.204 & 641.837 \\
\hline os Industriais de $\mathbf{U}$. & 0 & 0 & 0 & 0 & 0 & 0 & 0 & \\
\hline 19 & 0 & 0 & 0 & 0 & 0 & 0 & 0 & \\
\hline orte e M. Comércio & 0 & 0 & 0 & 0 & 0 & 0 & 0 & \\
\hline $21 \mathrm{Se}$ & 0 & 0 & 0 & 0 & 0 & 0 & 0 & \\
\hline Total & 4.135.856 & 1.056 .620 & 731.772 & 998.813 & 470.092 & 7.393 .153 & 36.158 .001 & 43.551 .154 \\
\hline
\end{tabular}

D6

Exportações Brasileiras para o Mercosul, Chile e Bolivia - 1995 - US\$ milhões (FOB)

\begin{tabular}{|c|c|c|c|c|c|c|c|c|}
\hline & Argentina & Paraguai & Uruguai & Chile & Bolivia & Total & R. Mundo & Total \\
\hline 1 Agropecuária & 170.307 & 16.815 & 69.177 & 28.159 & 5.181 & 289.639 & 4.152 .215 & 4.441 .854 \\
\hline 2 Mineração & 39.002 & 38.404 & 30.895 & 1.001 & 770 & 110.072 & 300.744 & 410.816 \\
\hline 3 Minerais não Metálicos & 179.681 & 46.642 & 15.976 & 29.788 & 19.431 & 291.518 & 3.082 .600 & 3.374.118 \\
\hline 4 Metalurgia & 1.016 .442 & 250.587 & 142.488 & 376.322 & 150.288 & 1.936 .127 & 9.429 .846 & 11.365 .973 \\
\hline 5 Mecânica e Material Elétrico & 250.086 & 82.199 & 46.786 & 74.200 & 36.935 & 490.206 & 1.250 .746 & 1.740 .952 \\
\hline 6 Material de Transporte & 781.094 & 130.000 & 206.254 & 262.831 & 42.319 & 1.422 .498 & 1.913 .673 & 3.336 .171 \\
\hline 7 Madeira e Mobiliário & 66.136 & 7.289 & 27.705 & 8.793 & 4.218 & 114.141 & 2.835 .457 & 2.949 .598 \\
\hline 8 Papel e Papelão & 206.848 & 41.271 & 32.274 & 72.357 & 28.778 & 381.528 & 874.518 & 1.256 .046 \\
\hline 9 Borracha & 93.231 & 92.476 & 16.204 & 38.551 & 27.779 & 268.241 & 426.613 & 694.854 \\
\hline 10 Indústria Química & 515.331 & 129.195 & 40.601 & 84.950 & 37.782 & 807.859 & 1.478 .109 & 2.285 .968 \\
\hline 11 Indústria Farmacêutica & 46.446 & 14.470 & 9.997 & 12.714 & 12.983 & 96.610 & 156.159 & 252.769 \\
\hline 12 Plásticos & 239.429 & 46.522 & 51.258 & 56.292 & 24.796 & 418.297 & 391.094 & 809.391 \\
\hline 13 Indústria Têxtil & 119.422 & 41.908 & 40.546 & 43.300 & 42.743 & 287.919 & 626.611 & 914.530 \\
\hline 14 Vestuário & 58.403 & 31.674 & 18.289 & 13.039 & 26.524 & 147.929 & 384.286 & 532.215 \\
\hline 15 Calçados e Couros & 21.934 & 29.171 & 8.087 & 20.746 & 24.595 & 104.533 & 2.019.716 & 2.124.249 \\
\hline 16 Produtos Alimentares & 204.526 & 280.528 & 49.490 & 54.759 & 38.573 & 627.876 & 8.591 .902 & 9.219 .778 \\
\hline 17 Diversos & 32.810 & 21.579 & 5.868 & 32.669 & 6.378 & 99.304 & 701.693 & 800.997 \\
\hline 18 Serviços Industriais de U.P. & 0 & 0 & 0 & 0 & 0 & 0 & 0 & 0 \\
\hline 19 Construção Civil & 0 & 0 & 0 & 0 & 0 & 0 & 0 & 0 \\
\hline 20 Transporte e $\mathrm{M}$. Comércio & 0 & 0 & 0 & 0 & 0 & 0 & 0 & 0 \\
\hline 21 Serviços & 0 & 0 & 0 & 0 & 0 & 0 & 0 & 0 \\
\hline Total & 4.041 .128 & 1.300 .730 & 811.895 & 1.210 .471 & 530.073 & 7.894.297 & 38.615 .982 & 46.510 .279 \\
\hline
\end{tabular}


D7

Exportaçōes Brasileiras para o Mercosul, Chile e Bolívia - 1996 - US\$ milhōes (FOB)

\begin{tabular}{|c|c|c|c|c|c|c|c|c|}
\hline & Argentina & Paraguai & Uruguai & Chile & Bolivia & Total & R. Mundo & Total \\
\hline 1 Agro & 220.881 & 22.991 & 72.497 & 30.762 & 5.355 & 352.486 & 4.423 .574 & 4.776 .060 \\
\hline 2 Mineração & 35.224 & 40.599 & 11.019 & 1.161 & 1.634 & 89.637 & 331.320 & 420.957 \\
\hline 3 Minerais não Metálicos & 222.728 & 50.816 & 15.181 & 29.166 & 15.513 & 333.404 & 3.230 .579 & 3.563 .983 \\
\hline 4 Metalurgia & 1.280 .804 & 255.655 & 144.894 & 166.476 & 137.161 & 1.984 .990 & 9.468 .694 & 11.453 .684 \\
\hline 5 Mecânica e Material Elétrico & 295.766 & 109.913 & 42.090 & 67.488 & 58.009 & 573.266 & 1.232 .105 & 1.805 .371 \\
\hline 6 Materia & 1.260 .832 & 102.351 & 142.715 & 254.805 & 42.325 & 1.803 .028 & 1.917 .817 & 3.720 .845 \\
\hline obiliário & 80.805 & 7.607 & 24.403 & 7.929 & 3.260 & 124.004 & 2.338 .418 & 2.462.422 \\
\hline 8 Papel e Pa & 240.098 & 38.942 & 32.412 & 38.009 & 17.437 & 366.898 & 590.657 & 957.555 \\
\hline 9 Bort & 128.114 & 114.779 & 471 & 35.213 & 34.567 & 328.144 & 396.241 & 724.385 \\
\hline 10 Ind & 527.829 & 151.455 & 59.399 & 68.873 & 44.850 & 852.406 & 1.597 .125 & 2.449 .531 \\
\hline $11 \mathrm{Ir}$ & 63.556 & 15.813 & 11.391 & 13.072 & 12.802 & 116.634 & 163.181 & 279.815 \\
\hline $12 P$ & 250.872 & 44.815 & 62.684 & 58.144 & 23.353 & 439.868 & 294.625 & 734.493 \\
\hline Têxtil & 199.450 & 39.022 & 33.931 & 43.072 & 44.836 & 360.311 & 456.788 & 817.099 \\
\hline $14 V$ & 80.240 & 33.523 & 22.335 & 16.306 & 21.720 & 174.124 & 305.076 & 479.200 \\
\hline $15 \mathrm{C}$ & 38.357 & 26.093 & 11.429 & 23.753 & 26.879 & 126.511 & 2.263 .673 & 2.390 .184 \\
\hline 16 Produtos Al & 220.807 & 249.489 & 103.258 & 59.273 & 35.300 & 668.127 & 9.223 .224 & 9.891 .351 \\
\hline 17 Dive & 18.188 & 20.363 & 4.865 & 8.277 & 6.126 & 57.819 & 124.514 & 182.333 \\
\hline $18 \mathrm{Se}$ & 0 & 0 & 0 & 0 & 0 & 0 & 0 & 0 \\
\hline 19 Construção Civil & 0 & 0 & 0 & 0 & 0 & 0 & 0 & 0 \\
\hline orte e M. Comércio & 0 & 0 & 0 & 0 & 0 & 0 & 0 & 0 \\
\hline 21 Serviços & 0 & 0 & 0 & 0 & 0 & 0 & 0 & 0 \\
\hline Total & 5.164 .551 & 1.324 .226 & 809.974 & 921.779 & 531.127 & 8.751 .657 & 38.357 .611 & 47.109 .268 \\
\hline
\end{tabular}

D8

Importações Brasileiras do Mercosul, Chile e Bolivia - 1990 - US\$ milhões(FOB)

\begin{tabular}{|c|c|c|c|c|c|c|c|c|}
\hline & Argentina & Paraquai & Uruguai & Chile & Bolivia & Total & R. Mundo & Total \\
\hline 1 Agropecuária & 648.660 & 142.314 & 262.573 & 110.201 & 13.469 & 1.177.217 & 521.155 & 1.698 .372 \\
\hline 2 Mineraçāo & 13.462 & 0 & 0 & 0 & 0 & 13.462 & 4.924 .626 & 4.938 .088 \\
\hline 3 Minerais não Metálicos & 111.419 & 20.731 & 3.770 & 9.408 & 9.035 & 154.363 & 289.859 & 444.222 \\
\hline 4 Metalurgia & 152.349 & 480 & 12.660 & 216.815 & 376 & 382.680 & 5.461 .173 & 5.839 .752 \\
\hline 5 Mecânica e Material Eétrico & 20.540 & 182 & 5.324 & 1.548 & 0 & 27.594 & 48.853 & 76.447 \\
\hline 6 Material de Transporte & 59.739 & 642 & 1.219 & 3 & 0 & 61.63 & 2.066 .527 & 2.128.130 \\
\hline 7 Madejra e Mobiliário & 16.676 & 30.813 & 1.788 & 19.101 & 4.384 & 72.762 & 9.885 & 82.647 \\
\hline 8 Papel e Papeläo & 36.198 & 269 & 2.915 & 28.511 & 0 & 67.893 & 227.566 & 295.459 \\
\hline 9 Borracha & 7.727 & 30 & 24.058 & 850 & 1.287 & 33.952 & 247.044 & 280.996 \\
\hline 10 Indústria Quimica & 91.916 & 4.310 & 70.995 & 51.867 & 404 & 219.492 & 2.666 .914 & 2.886 .406 \\
\hline 11 Indústria Farmacếrtica & 2.190 & 12 & 6.983 & 16.877 & 0 & 26.062 & 186.751 & 212.813 \\
\hline 12 Plásticos & 28.744 & 7 & 17.948 & 144 & 0 & 46.843 & 420.106 & 466.949 \\
\hline 13 Indústria Têxtil & 48.414 & 124.989 & 28.605 & 8.537 & 2.732 & 213.277 & 290.859 & 504.136 \\
\hline 14 Vestuário & 2.150 & 5.055 & 28.667 & 18 & 314 & 36.204 & 7.185 & 43.389 \\
\hline 15 Calçados e Couros & 36.338 & 1.051 & 100.445 & 1.436 & 2.258 & 141.538 & 52.680 & 194.218 \\
\hline 16 Produtos Alimentares & 87.312 & 1.891 & 16.944 & 20.719 & 1.079 & 127.945 & 367.930 & 495.875 \\
\hline 17 Diversos & 35.643 & 0 & 3.332 & 10 & 0 & 38.985 & 34.572 & 73.557 \\
\hline 18 Serviços Industriais de U.P. & 0 & 0 & 0 & 0 & 0 & 0 & 0 & 0 \\
\hline 19 Construçāo Civil & 0 & 0 & 0 & 0 & 0 & 0 & 0 & 0 \\
\hline 20 Transporte e M. Comércio & 0 & 0 & 0 & 0 & 0 & 0 & 0 & 0 \\
\hline 21 Serviços & 0 & 0 & 0 & 0 & 0 & 0 & 0 & 0 \\
\hline Total & 1.518.171 & 339.509 & 592.620 & 349.298 & 38.173 & 2.837.771 & 17.823 .685 & 20.661 .456 \\
\hline
\end{tabular}


D9

Importaçōes Brasileiras do Mercosul, Chile e Bolivia - 1991 - US\$ milhōes (FOB)

\begin{tabular}{|c|c|c|c|c|c|c|c|c|}
\hline & Argentina & Paraguai & Uruguai & Chile & Bolivia & Total & R. Mundo & Total \\
\hline 1 Agropecuá ria & 668.236 & 38.476 & 223.705 & 75.612 & 4.054 & $\begin{array}{r}668.236 \\
53131\end{array}$ & $\begin{array}{r}719.514 \\
975733\end{array}$ & 1.729 .597 \\
\hline $\begin{array}{l}2 \text { Miner } \\
3 \text { Miner }\end{array}$ & $\begin{array}{r}53.131 \\
111.419\end{array}$ & $\begin{array}{r}0 \\
20.731\end{array}$ & $\begin{array}{r}12 \\
3.770\end{array}$ & $\begin{array}{r}0 \\
9.408\end{array}$ & $\begin{array}{r}0 \\
7.035\end{array}$ & $\begin{array}{r}53.131 \\
111.419\end{array}$ & $\begin{array}{r}4.975 .733 \\
300.025\end{array}$ & $\begin{array}{r}5.028 .876 \\
452.388\end{array}$ \\
\hline 4 Metalurgia & 172.486 & 207 & 10.463 & 211.144 & 187 & 172.486 & 5.474 .942 & 5.931 .420 \\
\hline Material EI & 26.466 & 127 & 4.748 & 940 & 34 & 26.466 & 45.539 & 77.854 \\
\hline 6 Mat & 108.939 & 207 & 1.441 & 77 & 24 & 108.939 & 2.056 .568 & 2.167 .256 \\
\hline 7 Madeira e Mobiliário & 7.862 & 20.143 & 899 & 23.975 & 2.143 & 7.862 & 29.143 & 84.165 \\
\hline apelão & 15.665 & 351 & 3.166 & 42.558 & 2 & 15.665 & 239.149 & 300.891 \\
\hline 9 Borr & 7.091 & 7 & 13.027 & 335 & 418 & 7.091 & 265.284 & 286.162 \\
\hline 10 Ind & 126.665 & 1.533 & 45.930 & 47.081 & 134 & 126.665 & 2.718 .130 & 2.939 .473 \\
\hline Imacéutici & 1.462 & 0 & 12.400 & 15.867 & 2 & 1.462 & 186.995 & 216.726 \\
\hline 12 Plá & 41.440 & 3 & 16.059 & 224 & 0 & 41.440 & 417.808 & 475.534 \\
\hline Téxtil & 51.897 & 122.084 & 26.195 & 4.049 & 5.479 & 51.897 & 303.704 & 513.408 \\
\hline 14 Vest & 2.061 & 5.244 & 28.685 & 398 & 0 & 2.061 & 7.799 & 44.187 \\
\hline $15 \mathrm{Cz}$ & 107.724 & 632 & 30.679 & 4.277 & 939 & 107.724 & 53.537 & 197.788 \\
\hline $16 \mathrm{Pr}$ & 82 & 9.814 & 11.499 & 21.653 & 1.402 & 78.482 & 382.142 & 504.992 \\
\hline $17 \mathrm{Di}$ & 35.643 & 27 & 1.422 & 39 & 0 & 35.643 & 53.475 & 90.606 \\
\hline 18 Serviços Industriais d & 0 & 0 & 0 & 0 & 0 & 0 & 0 & 0 \\
\hline 19 Construção Civil & 0 & 0 & 0 & 0 & 0 & 0 & 0 & 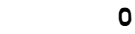 \\
\hline e M. Comé & 0 & 0 & 0 & 0 & 0 & 0 & 0 & 0 \\
\hline $21 \mathrm{Se}$ & 0 & 0 & 0 & 0 & 0 & 0 & 0 & 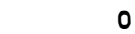 \\
\hline To & 43.678 & 232.828 & 436.797 & 370.222 & 28.311 & 743.678 & \#\#\#\#立 & \#\#\# \\
\hline
\end{tabular}

D10

Importaçőes Brasileiras do Mercosul, Chile e Bollvia - 1992 (US\$ milhỏes/FOB)

\begin{tabular}{|c|c|c|c|c|c|c|c|c|}
\hline & Argentina & Paraguai & Uruguai & Chile & Bolivia & Total & R. Mundo & Total \\
\hline 1 Agropecuária & 803.061 & 18.155 & 142.005 & 41.359 & 4.583 & 1.009 .163 & 662.534 & 1.671 .697 \\
\hline 2 Mineraçăo & 109.994 & 0 & 110 & 0 & 0 & 110.104 & 4.750 .232 & 4.860 .336 \\
\hline 3 Minerais não Metálicos & 9.590 & 0 & 3.695 & 153.844 & 3.080 & 170.209 & 267.263 & 437.472 \\
\hline 4 Metalurgia & 156.299 & 271 & 6.901 & 169.304 & 114 & 332.889 & 5.471 .882 & 5.804 .771 \\
\hline 5 Mecannica e Mater & 19.461 & 29 & 2.338 & 105 & 10 & 21.943 & 53.402 & 75.345 \\
\hline 6 Material de Transporte & 222.060 & 8 & 2.856 & 115 & 12 & 225.051 & 1.869 .851 & 2.094 .902 \\
\hline 7 Madeira e Mobiliário & 3.137 & 23.067 & 410 & 14.359 & 2.422 & 43.395 & 37.840 & 81.235 \\
\hline Papelão & 8.386 & 432 & 5.466 & 12.634 & 98 & 27.016 & 263.453 & 290.469 \\
\hline 9 Borracha & 7.221 & 4 & 13.441 & 897 & 56 & 21.619 & 255.245 & 276.864 \\
\hline 10 Indústria Química & 120.665 & 1.004 & 28.539 & 38.474 & 502 & 189.184 & 2.652 .106 & 2.841 .290 \\
\hline 11 Indústria Farmacéutica & 3.481 & 4.661 & 7.805 & 1.329 & 0 & 17.276 & 191.656 & 208.932 \\
\hline 12 Plásticos & 50.676 & 0 & 20.964 & 300 & 25 & 71.965 & 387.973 & 459.938 \\
\hline 13 Indústria Téxtil & 60.503 & 112.664 & 25.096 & 1.637 & 1.387 & 201.287 & 295.035 & 496.322 \\
\hline $14 \mathrm{Ve}$ & 1.289 & 1.274 & 12.681 & 34 & 192 & 15.470 & 28.053 & 43.523 \\
\hline Jos e Couros & 92.974 & 1.769 & 15.990 & 831 & 0 & 111.564 & 78.937 & 190.501 \\
\hline 16 Produtos Alimentares & 61.392 & 31.639 & 12.115 & 42.695 & 3.038 & 150.879 & 337.695 & 488.574 \\
\hline 17 Diversos & 1.432 & 17 & 1.523 & 3 & 0 & 2.972 & 10.483 & 13.455 \\
\hline is de U.I & 0 & 0 & 0 & b & 0 & 0 & 0 & 0 \\
\hline 19 Construção Civil & 0 & 0 & 0 & 0 & 0 & 0 & 0 & 0 \\
\hline 20 Transporte e M. Comércio & 0 & 0 & 0 & 0 & 0 & 0 & 0 & 0 \\
\hline 21 Serviços & 0 & 0 & 0 & 0 & 0 & 0 & 0 & 0 \\
\hline Total & 1.731 .621 & 194.994 & 301.935 & 477.917 & 15.519 & 2.721 .986 & 17.613 .640 & 20.335 .626 \\
\hline
\end{tabular}


D11

Importaçōes Brasileiras do Mercosul, Chile e Bolivia - 1993 (US\$ milhōes/FOB)

\begin{tabular}{|c|c|c|c|c|c|c|c|c|}
\hline & Argentina & Paraguai & Uruguai & Chile & Bolivia & Total & R. Mundo & Total \\
\hline 1 Agropecuária & 1.010 .877 & 18.971 & 211.757 & 59.560 & 805 & 1.301 .970 & 740.791 & 761 \\
\hline 2 Miner & 525.447 & 0 & 30 & 0 & 0 & 525.477 & 4.546 .893 & 5.072 .370 \\
\hline não Metálicos & 11.716 & 11 & 6.4921 & 135.559 & 7.057 & 160.835 & 262.783 & 423.618 \\
\hline 4 Metalurgia & 211.090 & 788 & 8.400 & 120.371 & 312 & 340.961 & 4.155 .268 & 4.496.229 \\
\hline 5 Mecânica e Material Elétric & 25.681 & 1 & 2.117 & 489 & 0 & 28.288 & 3.430 .729 & 3.459 .017 \\
\hline 6 Material de Transporte & 476.344 & 31 & 7.632 & 912 & 0 & 484.919 & 1.617.987 & 2.102 .906 \\
\hline 7 Madeira e Mobiliário & 3.245 & 31.456 & 488 & 18.762 & 1.624 & 55.575 & 74.424 & 129.999 \\
\hline 8 Papel e Papelão & 7.556 & 426 & 887 & 18.849 & 102 & 27.820 & 328.715 & 356.535 \\
\hline 9 Bo & 17.386 & 8 & 20.501 & 90 & 12 & 37.997 & 320.517 & 358.514 \\
\hline Química & 110.573 & 875 & 23.468 & 37.964 & 629 & 173.509 & 3.213.071 & 3.386 .580 \\
\hline tria Farmacêutica & 8.095 & 21.542 & 5.419 & 1.732 & 0 & 36.788 & 048 & 297.836 \\
\hline $12 \mathrm{PI}$ & 45.585 & 5 & 21.771 & 1.367 & 0 & 68.728 & 584.139 & 652.867 \\
\hline ia Têxtil & 79.617 & 157.665 & 28.023 & 3.651 & 824 & 269.780 & 861.686 & 1.131 .466 \\
\hline $14 \mathrm{Ve}$ & 913 & 1.053 & 12.443 & 67 & 815 & 15.291 & 37.417 & 52.708 \\
\hline $15 \mathrm{C}$ & 94.080 & 11.085 & 22.385 & 904 & 2.586 & 131.040 & 124.832 & 255.872 \\
\hline tos Alimentares & 86.722 & 31.672 & 11.952 & 35.305 & 4.032 & 169.683 & 496.819 & 666.502 \\
\hline $17 \mathrm{D}$ & 2.330 & 15 & 1.601 & 14 & 4 & 3.964 & 54.393 & 58.357 \\
\hline iais de U.I & 0 & 0 & 0 & 0 & 0 & 0 & 0 & 0 \\
\hline $19 c$ & 0 & 0 & 0 & 0 & 0 & 0 & 0 & 0 \\
\hline $20 \mathrm{~T}$ & 0 & 0 & 0 & 0 & 0 & 0 & 0 & 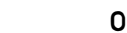 \\
\hline $21 \mathrm{Se}$ & 0 & 0 & 0 & 0 & 0 & 0 & 0 & 0 \\
\hline Total & 2.717.257 & 275.604 & 385.366 & 435.596 & 18.802 & 3.832 .625 & 21.111.512 & \#\#\#\#\#\# \\
\hline
\end{tabular}

D12

Importaçōes Brasileiras do Mercosul, Chile e Bolivia - 1994 (US\$ milhões/FOB)

\begin{tabular}{|c|c|c|c|c|c|c|c|c|}
\hline & Argentina & Paraguai & Uruguai & Chile & Bolivia & Total & R. Mundo & Total \\
\hline 1 Agro & 1.271.694 & 110.437 & 24.742 & 1.689 & 3.750 & 1.782 .312 & 1.124 .013 & 2.906 .325 \\
\hline $2 M$ & 10.159 & 0 & & 0 & 0 & 610.159 & 4.156 .246 & 4.766 .405 \\
\hline nāo Metálicos & 16.818 & 417 & 7.513 & 144.207 & 8.874 & 177.829 & 353.264 & 531.093 \\
\hline $4 M$ & 232.113 & 8.928 & 11.354 & 152.888 & 45 & 405.328 & 6.411 .552 & 6.816 .880 \\
\hline e Material Elétric & 55.916 & 69 & 5.038 & 551 & 3 & 61.577 & 4.812.477 & 4.874 .054 \\
\hline 6 Mate & 669.072 & 0 & 25.984 & 447 & 0 & 695.503 & 2.700 .799 & 3.396 .302 \\
\hline $7 \mathrm{~N}$ & 7.853 & 29.630 & 7.167 & 24.363 & 1.828 & 70.841 & 97.752 & 593 \\
\hline $8 P$ & 10.511 & 604 & 546 & 25.728 & 70 & 37.459 & 446.585 & 044 \\
\hline $9 \mathrm{~B}$ & 35 & 1 & 27.724 & 1.147 & 44 & 64.382 & .783 & 530.165 \\
\hline 10 I & 148.136 & 862 & 22.163 & 114.692 & 100 & 285.953 & 3.991 .390 & 4.277 .343 \\
\hline acêutica & 74 & 2.844 & 8.414 & 1.787 & 0 & 31.619 & 461.269 & 492.888 \\
\hline $12 P$ & 65.351 & 23 & 25.927 & 1.091 & 0 & 92.392 & 711.433 & 803.825 \\
\hline Têxtil & 192.081 & 139.417 & 35.767 & 5.324 & 1.720 & 374.309 & 848.505 & 1.222 .814 \\
\hline $14 \mathrm{~V}$ & 2.460 & 2.099 & 19.394 & 22 & 956 & 25.132 & 90.807 & 115.939 \\
\hline 15 & 103.607 & 9.897 & 15.851 & 678 & 923 & 130.956 & 170.142 & 301.098 \\
\hline $16 P$ & 21 & 47.221 & 28.809 & 46.556 & 5.007 & 345.627 & 891.702 & 1.237 .329 \\
\hline $17 \mathrm{D}$ & 4.115 & 2 & 2.449 & 265 & 8 & 6.839 & 146.746 & 153.585 \\
\hline 18 & 0 & 0 & 0 & 0 & 0 & 0 & 0 & \\
\hline 19 & 0 & 0 & 0 & 0 & 0 & 0 & 0 & \\
\hline h. Comérc & 0 & 0 & 0 & 0 & 0 & 0 & 0 & \\
\hline 21 Serviç & 0 & 0 & 0 & 0 & 0 & 0 & 0 & \\
\hline Total & 3.661 .960 & 352.451 & 568.842 & 591.636 & 23.328 & 5.198 .217 & 27.880 .465 & 33.078 .682 \\
\hline
\end{tabular}


D13

Importaçōes Brasileiras do Mercosul, Chile e Bolivia - 1995 - US\$ milhões (FOB)

\begin{tabular}{|c|c|c|c|c|c|c|c|c|}
\hline & Argentina & Paraguai & Uruguai & Chile & Bolivia & Total & R. Mundo & Total \\
\hline Agropecuária & 1.731 .904 & 219.293 & 372.502 & 153.817 & 3.750 & 2.481 .903 & 1.573 .806 & 4.055.709 \\
\hline 2 Min & 823.552 & 0 & 2.104 & 858 & 0 & 826.514 & 4.754.926 & 5.581 .440 \\
\hline 3 Minerais nāo Metálicos & 31.609 & 171 & 8.803 & 265.832 & 8.874 & 317.366 & 512.829 & 830.195 \\
\hline 4 Metalurgia & 426.395 & 2.804 & 19.188 & 318.503 & 45 & 767.238 & 9.498 .050 & 10.265 .288 \\
\hline 5 Mecânica e Material Elétric & 127.310 & 386 & 8.339 & 1.982 & 3 & 138.022 & 7.599.762 & 7.737.784 \\
\hline de Transporte & 1.026.227 & 49 & 21.439 & 1.145 & 0 & 1.048 .868 & 4.991.970 & 6.040 .838 \\
\hline 7 Madeira e Mobiliário & 28.614 & 32.314 & 15.489 & 49.110 & 1.828 & 127.144 & 244.189 & 371.333 \\
\hline 8 Papel e Papelāo & 81.605 & 1.759 & 4.596 & 91.610 & 70 & 179.590 & 1.017.177 & 1.196 .767 \\
\hline 9 Bor & 61.007 & 128 & 32.133 & 4.167 & 44 & 97.454 & 710.541 & 807.995 \\
\hline Química & 199.264 & 2.873 & 24.580 & 117.852 & 100 & 344.688 & 5.298.283 & 5.642 .971 \\
\hline 11 Indústria Farmac & 35.514 & 2.149 & 18.305 & 2.386 & 0 & 58.354 & 602.306 & 660.660 \\
\hline 12 Plásticos & 132.408 & 62 & 56.038 & 1.928 & 0 & 190.436 & 1.412 .345 & 1.602 .781 \\
\hline 13 Indústria Têxtil & 279.017 & 171.749 & 51.037 & 13.585 & 1.720 & 515.546 & 1.423 .338 & 1.938 .884 \\
\hline $14 \mathrm{Ve}$ & 15.733 & 4.051 & 39.878 & 1.771 & 956 & 63.940 & 321.740 & 385.680 \\
\hline $15 \mathrm{Ce}$ & 150.530 & 4.302 & 17.202 & 475 & 923 & 173.064 & 284.456 & 457.520 \\
\hline 16 Produtos Alimentares & 315.000 & 72.541 & 43.846 & 68.467 & 5.007 & 507.136 & 1.482 .877 & 1.990 .013 \\
\hline 17 Diversos & 15.699 & 14 & 2.398 & 362 & 8 & 18.512 & 387.571 & 406.083 \\
\hline 18 Serviços Industriais de U.I & 0 & 0 & 0 & 0 & 0 & 0 & 0 & 0 \\
\hline $19 \mathrm{C}$ & 0 & 0 & 0 & 0 & 0 & 0 & 0 & 0 \\
\hline 20 Transporte e M. Comércio & 0 & 0 & 0 & 0 & 0 & 0 & 0 & 0 \\
\hline 21 Serviços & 0 & 0 & 0 & 0 & 0 & 0 & 0 & 0 \\
\hline Total & 5.481 .388 & 514.645 & 737.877 & 1.093 .850 & 23.328 & 7.855 .775 & 42.116 .166 & 49.971 .941 \\
\hline
\end{tabular}

D14

Importações Brasileiras do Mercosul, Chile e Bolivia - 1996 - US\$ milhões (FOB)

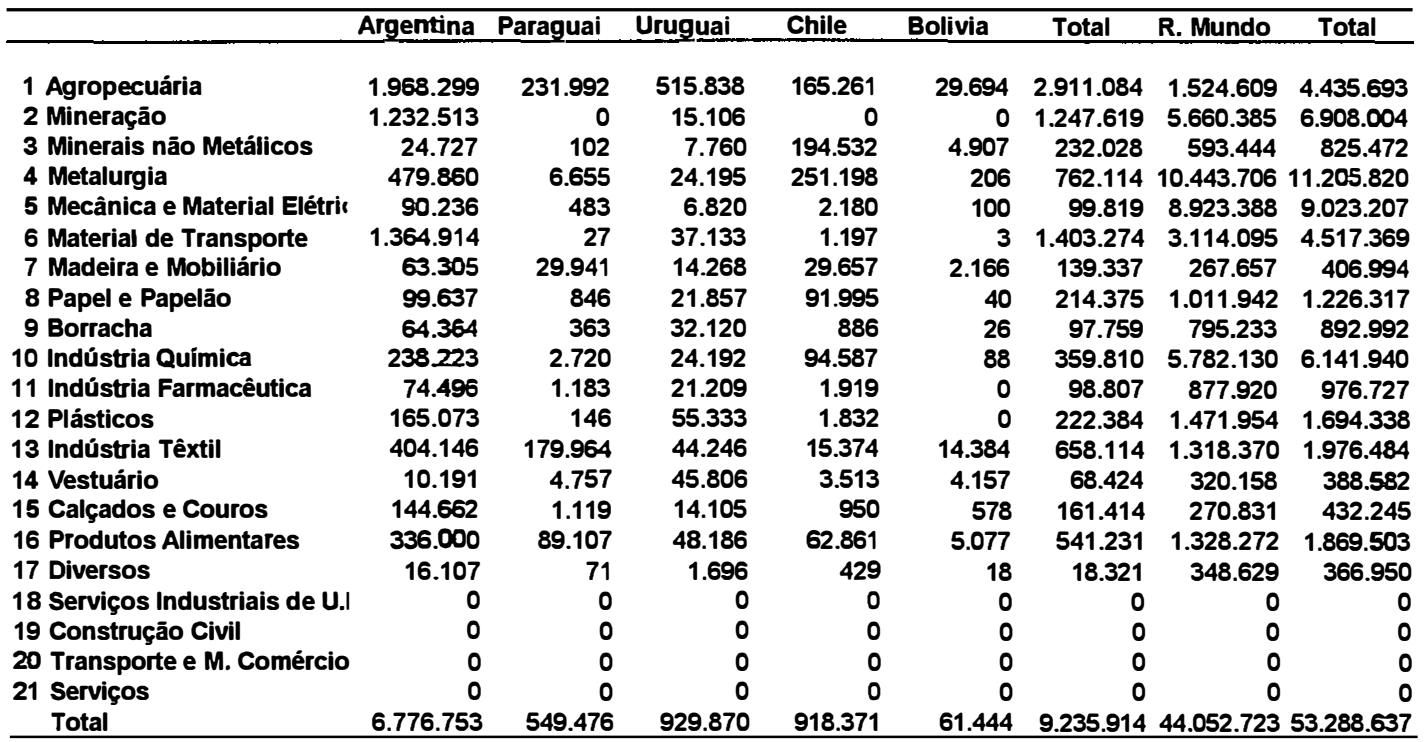


D15

Participação das Exportações para a Argentina nas exportações totais brasileiras - 1990 - 96

\begin{tabular}{|c|c|c|c|c|c|c|c|}
\hline Produtos & 1990 & 1991 & 1992 & 1993 & 1994 & 1995 & 1996 \\
\hline 1 Agropecuária & 5,56 & 10,67 & 4,81 & 4,92 & 3,22 & 3,83 & 4,62 \\
\hline 2 Mineração & 1,21 & 1,26 & 3,95 & 11,64 & 11,64 & 9,49 & 8,37 \\
\hline 3 Minerais não Metálicos & 4,19 & 4,19 & 4,20 & 5,37 & 5,35 & 5,33 & 6,25 \\
\hline 4 Metalurgia & 2,49 & 5,39 & 8,58 & 9,27 & 10,22 & 8,94 & 11,18 \\
\hline 5 Mecânica e Material Elétriı & 3,86 & 8,94 & 12,23 & 14,43 & 14,51 & 14,36 & 16,38 \\
\hline 6 Material de Transporte & 4,06 & 16,07 & 25,67 & 26,52 & 26,28 & 23,41 & 33,89 \\
\hline 7 Madeira e Mobiliário & 5,95 & 5,19 & 2,76 & 3,77 & 3,87 & 2,24 & 3,28 \\
\hline 8 Papel e Papelão & 2,62 & 12,11 & 17,08 & 23,00 & 17,48 & 16,47 & 25,07 \\
\hline 9 Borracha & 4,43 & 15,70 & 18,00 & 15,15 & 15,61 & 13,42 & 17,69 \\
\hline 10 Indústria Química & 13,37 & 17,17 & 14,92 & 17,91 & $20, \infty 0$ & 22,54 & 21,55 \\
\hline 11 Indústria Farmacêutica & 0,31 & 4,15 & 8,24 & 10,54 & 13,35 & 18,37 & 22,71 \\
\hline 12 Plásticos & 5,21 & 14,16 & 19,57 & 25,04 & 26,07 & 29,58 & 34,16 \\
\hline 13 Indústria Têxtil & 0,21 & 0,89 & 10,37 & 15,44 & 13,98 & 13,06 & 24,41 \\
\hline 14 Vestuário & 0,01 & 0,68 & 9,01 & 7,16 & 10,62 & 10,97 & 16,74 \\
\hline 15 Calçados e Couros & 0,04 & 0,48 & 0,74 & 0,50 & 0,89 & $1, \infty 3$ & 1,60 \\
\hline 16 Produtos Alimentares & 0,42 & 1,01 & 1,75 & 2,28 & 2,74 & 2,22 & 2,23 \\
\hline 17 Diversos & 2,39 & 15,31 & 3,35 & 7,35 & 4,40 & 4,10 & 9,98 \\
\hline 18 Serviços Industriais de U. & $0, \infty$ & 0,00 & 0,00 & 0,00 & $0, \infty 0$ & 0,00 & $0, \infty 0$ \\
\hline 19 Construçāo Civil & 0,00 & 0,00 & $0, \infty$ & 0,00 & 0,00 & $0, \infty$ & 0,00 \\
\hline 20 Transporte e M. Comércio & 0,00 & 0,00 & 0,00 & 0,00 & 0,00 & 0,00 & $0, \infty$ \\
\hline 21 Serviços & 0,00 & $0, \infty$ & 0,00 & $0, \infty$ & $0, \infty$ & 0,00 & 0,00 \\
\hline Total & 56,33 & 133,40 & 165,23 & 200,27 & 200,83 & 199,38 & 260,12 \\
\hline
\end{tabular}

D16

Participação das Exportações para o Paraguai nas exportações totais brasileiras - 1990 - 96

\begin{tabular}{|c|c|c|c|c|c|c|c|}
\hline Produtos & 1990 & 1991 & 1992 & 1993 & 1994 & 1995 & 1996 \\
\hline 1 Agropecuária & 0,21 & 0,40 & 0,13 & 0,14 & 0,18 & 0,38 & 0,48 \\
\hline 2 Mineração & 3,31 & 3,26 & 4,43 & 4,86 & 4,22 & 9,35 & 9,64 \\
\hline 3 Minerais não Metálicos & 0,78 & 0,78 & 0,83 & 1,23 & 1,14 & 1,38 & 1,43 \\
\hline 4 Metalurgia & 1,17 & 1,54 & 1,27 & 2,03 & 2,08 & 2,20 & 2,23 \\
\hline 5 Mecânica e Material Elétriı & 2,48 & 3,12 & 2,21 & 3,34 & 3,57 & 4,72 & $6, \infty$ \\
\hline 6 Material de Transporte & 2,22 & 2,12 & $1, \infty 3$ & 1,95 & 2,41 & 3,90 & 2,75 \\
\hline 7 Madeira e Mobiliário & 2,45 & 0,48 & 0,14 & 0,21 & 0,22 & 0,25 & 0,31 \\
\hline 8 Papel e Papelão & 1,90 & 2,14 & 2,18 & 3,67 & 2,89 & 3,29 & 4,07 \\
\hline 9 Borracha & 10,96 & 10,44 & 8,46 & 14,57 & 16,25 & 13,31 & 15,85 \\
\hline 10 Indústria Química & 2,66 & 3,96 & 2,86 & 5,39 & 5,52 & 5,ळ & 6,18 \\
\hline 11 Indústria Farmacêutica & 1,93 & 14,33 & 6,22 & 8,99 & 6,78 & 5,72 & 5,65 \\
\hline 12 Plásticos & 2,74 & 3,26 & 3,02 & 4,20 & 4,58 & 5,75 & 6,10 \\
\hline 13 Indústria Têxtil & 0,37 & 0,36 & 2,11 & 4,82 & 4,92 & 4,58 & 4,78 \\
\hline 14 Vestuário & $1, \infty 3$ & 1,ळ5 & 6,92 & 8,87 & 6,66 & 5,95 & 7,00 \\
\hline 15 Calçados e Couros & 2,15 & 2,17 & 0,76 & 1,38 & 1,36 & 1,37 & $1, \infty$ \\
\hline 16 Produtos Alimentares & 0,65 & 1,22 & 1,60 & 2,64 & 2,59 & 3,04 & 2,52 \\
\hline 17 Diversos & 2,29 & 2,53 & 1,44 & 3,55 & 2,81 & 2,69 & 11,17 \\
\hline 18 Serviços Industriais de U.I & $0, \infty$ & 0,00 & 0,00 & 0,00 & 0,00 & 0,00 & 0,00 \\
\hline 19 Construção Civil & 0,00 & 0,00 & $0, \infty$ & $0, \infty$ & 0,00 & 0,00 & 0,00 \\
\hline 20 Transporte e M. Comércio & 0,00 & 0,00 & 0,00 & 0,00 & 0,00 & 0,00 & $0, \infty$ \\
\hline 21 Serviços & $0, \infty$ & 0,00 & 0,00 & 0,00 & 0,00 & 0,00 & 0,00 \\
\hline Total & 39,30 & 53,77 & 45,61 & 71,84 & 68,17 & 73,54 & 87,33 \\
\hline
\end{tabular}


D17

Participação das Exportações para o Uruguai nas exportações totais brasileiras - 1990 - 96

\begin{tabular}{|c|c|c|c|c|c|c|c|}
\hline Produtos & 1990 & 1991 & 1992 & 1993 & 1994 & 1995 & 1996 \\
\hline 1 Agropecuária & 5,16 & 4,24 & 1,19 & 1,44 & 1,05 & 1,56 & 1,52 \\
\hline 2 Mineração & 0.49 & 0,06 & 1,75 & 9,74 & 11,01 & 7,52 & 2,62 \\
\hline 3 Minerais não Metálicos & 0,14 & 0,14 & 0,24 & 0,43 & 0,52 & 0,47 & 0,43 \\
\hline 4 Metalurgia & 0.90 & 0,95 & 1,14 & 1,51 & 1,17 & 1,25 & 1,27 \\
\hline 5 Mecânica e Material Elétrir & 3,12 & 1,99 & 2,00 & 2,76 & 3,23 & 2,69 & 2,33 \\
\hline 6 Materlal de Transporte & 3,85 & 4,79 & 0,00 & 5,78 & 3,74 & 6,18 & 3,84 \\
\hline 7 Madeira e Mobiliário & 8,25 & 2,24 & 0,80 & 1,34 & 1,34 & 0,94 & 0,99 \\
\hline 8 Papel e Papelão & 1,16 & 2,12 & 2,59 & 3,09 & $2, \infty$ & 2,57 & 3,38 \\
\hline 9 Borracha & 1,82 & 2,19 & 2,32 & 2,22 & 2,14 & 2,33 & 2,14 \\
\hline 10 Indústria Química & 3,02 & 3,45 & 2,23 & 2,42 & 1,99 & 1,78 & 2,42 \\
\hline 11 Indústria Farmacêutica & 1,20 & 10,29 & 2,13 & 2,29 & 2,79 & 3,95 & 4,07 \\
\hline 12 Plásticos & 6.36 & 5,93 & 5,61 & 6,04 & 6,47 & 6,33 & 8,53 \\
\hline 13 Indústria Têxtil & 0,19 & 0,27 & 2,33 & 4,24 & 3,21 & 4,43 & 4.15 \\
\hline 14 Vestuário & 0.04 & 0,17 & 1,74 & 3,96 & 2,78 & 3,44 & 4,66 \\
\hline 15 Calçados e Couros & 1.23 & 0,96 & 0,35 & 0,36 & 0,36 & 0,38 & 0,48 \\
\hline 16 Produtos Alimentares & 0.11 & 0,18 & 0,26 & 0,54 & 0,48 & 0,54 & 1,04 \\
\hline 17 Diversos & 1.33 & 0,52 & 0,67 & 1,36 & 0,98 & 0,73 & 2,67 \\
\hline 18 Serviços Industriais de U.I & 0.00 & 0,00 & 0,00 & 0,00 & 0,00 & 0,00 & 0,00 \\
\hline 19 Construção Civil & 0.00 & 0,00 & 0,00 & 0,00 & 0,00 & 0,00 & 0,00 \\
\hline 20 Transporte e M. Comércio & 0,00 & 0,00 & 0,00 & 0,00 & 0,00 & 0,00 & 0,00 \\
\hline 21 Serviços & 0.00 & 0,00 & 0,00 & 0,00 & 0,00 & 0,00 & 0,00 \\
\hline Total & 38,37 & 40,50 & 27,37 & 49,52 & 45,87 & 47,10 & 46,54 \\
\hline
\end{tabular}

D18

Participação das Exportações para o Chile nas exportações totais brasileiras - 1990 - 96

\begin{tabular}{|c|c|c|c|c|c|c|c|}
\hline Produtos & 1990 & 1991 & 1992 & 1993 & 1994 & 1995 & 1996 \\
\hline 1 Agropecuária & 1,96 & 2,17 & 0,45 & 0,46 & 0,52 & 0,63 & 0,64 \\
\hline 2 Mineração & 0,04 & 0,88 & 0,34 & 0,15 & 0,13 & 0,24 & 0,28 \\
\hline 3 Minerais não Metálicos & 0,35 & 0,35 & 0,72 & 0,94 & 0,70 & 0,88 & 0,82 \\
\hline 4 Metalurgia & 2,49 & 2,94 & 2,99 & 3,85 & 2,91 & 3,31 & 1,45 \\
\hline 5 Mecânica e Material Elétriı & 4,86 & 3,94 & 3,44 & 3,74 & 3,20 & 4,26 & 3,74 \\
\hline 6 Material de Transporte & 0,02 & 11,54 & 8,32 & 9,11 & 6,85 & 7,88 & 6,85 \\
\hline 7 Madeira e Mobiliário & 1,88 & 0,42 & 0,13 & 0,24 & 0,17 & 0,30 & 0,32 \\
\hline 8 Papel e Papelão & 3,51 & 4,64 & 4,85 & 4,51 & 4,61 & 5,76 & 3,97 \\
\hline 9 Borracha & 4,99 & 5,30 & 5,55 & 6,53 & 4,31 & 5,55 & 4,86 \\
\hline 10 Indústria Química & 3,39 & 4,71 & 3,ఝ & 3,13 & 3,15 & 3,72 & 2,81 \\
\hline 11 Indústria Farmacêutica & 0,28 & 3,40 & 2,33 & 3,38 & 4,70 & 5,03 & 4,67 \\
\hline 12 Plásticos & 5,09 & 6,22 & 7,25 & 7,20 & 7,03 & 6,95 & 7,92 \\
\hline 13 Indústria Têxtil & 0,37 & $0, \widetilde{3}$ & 5,67 & 7,30 & 5,50 & 4,73 & 5,27 \\
\hline 14 Vestuário & 0,18 & 0,29 & 1,99 & 2,07 & 1,99 & 2,45 & 3,40 \\
\hline 15 Calçados e Couros & 0,11 & 0,31 & 0,50 & 0,58 & 0,76 & 0,98 & 0,99 \\
\hline 16 Produtos Alimentares & 0.22 & 0,48 & 0,49 & 0,48 & 0,65 & 0,59 & $0, \infty$ \\
\hline 17 Diversos & 4,50 & 4,57 & 1,39 & 3,32 & 1,61 & 4,08 & 4,54 \\
\hline 18 Serviços Industriais de U.! & 0,00 & 0,00 & 0,00 & 0,00 & 0,00 & 0,00 & 0,00 \\
\hline 19 Construção Civil & 0,00 & 0,00 & 0,00 & 0,00 & 0,00 & 0,00 & 0,00 \\
\hline 20 Transporte e $\mathrm{M}$. Comércio & 0.00 & 0,00 & 0,00 & 0,00 & 0,00 & 0,00 & 0,00 \\
\hline 21 Serviços & 0,00 & 0,00 & 0,00 & 0,00 & 0,00 & 0,00 & 0,00 \\
\hline Total & 34.24 & 52,80 & 50,07 & 57,00 & 48,80 & 57,35 & 53,14 \\
\hline
\end{tabular}


D19

Participação das Exportaçōes para a Bolivia nas exportaçōes totais brasileiras - 1990 - 96

\begin{tabular}{|c|c|c|c|c|c|c|c|}
\hline Produtos & 1990 & 1991 & 1992 & 1993 & 1994 & 1995 & 1996 \\
\hline 1 Agropecuária & $\overline{0,21}$ & 0,27 & 0,06 & 0,05 & 0,07 & 0,12 & 0,11 \\
\hline 2 Mineração & 0,02 & 0,06 & 0,13 & 0,50 & 0,21 & 0,19 & 0,39 \\
\hline 3 Minerais não Metálicos & 0,34 & 0,34 & 0,43 & 0,57 & 0,60 & 0,58 & 0,44 \\
\hline 4 Metalurgia & 0,79 & 1,17 & 1,21 & 1,38 & 1,36 & 1,32 & 1,20 \\
\hline 5 Mecânica e Material Elétriı & 1,92 & 2,02 & 1,79 & 1,91 & 1,73 & 2,12 & 3,21 \\
\hline 6 Material de Transporte & 0,92 & 1,45 & 0,97 & 0.93 & 1,20 & 1,27 & 1,14 \\
\hline 7 Madeira e Mobiliário & 2,59 & 0,71 & 0,18 & 0,21 & 0,22 & 0,14 & 0,13 \\
\hline 8 Papel e Papelão & 1,25 & 1,80 & 1,83 & 1,85 & 1,95 & 2,29 & 1,82 \\
\hline 9 Borracha & 1,55 & 1,79 & 2,01 & 2,85 & 3,62 & 4,00 & 4,77 \\
\hline 10 Indústria Química & 1,18 & 2,01 & 1,52 & 1,71 & 1,82 & 1,65 & 1,83 \\
\hline 11 Indústria Farmacêutica & 0,09 & 0,91 & 4,12 & 5,11 & 4,6 & 5,14 & 4,58 \\
\hline 12 Plásticos & 1,86 & 1,86 & 1,99 & 2,75 & 3,44 & 3,06 & 3,18 \\
\hline 13 Indústria Têxtil & 0,17 & 0,25 & 2,47 & 4,46 & 4,10 & 4,67 & 5,49 \\
\hline 14 Vestuário & 0,40 & 0,57 & 3,11 & 4,48 & 4,39 & 4,98 & 4,53 \\
\hline 15 Calçados e Couros & 2,94 & 1,52 & 0,54 & 0,59 & 0,73 & 1,16 & 1,12 \\
\hline 16 Produtos Alimentares & 0,20 & 0,33 & 0,43 & 0,56 & 0,44 & 0,42 & 0,36 \\
\hline 17 Diversos & 4,45 & 4,19 & 0,68 & 1,56 & 0,90 & 0,80 & 3,36 \\
\hline 18 Serviços Industriais de U.I & 0,00 & 0,00 & 0,00 & 0,00 & 0,00 & 0,00 & 0,00 \\
\hline 19 Construção Civil & 0,00 & 0,00 & 0,00 & 0,00 & 0,00 & 0,00 & 0,00 \\
\hline 20 Transporte e $M$. Comércio & 0,00 & 0,00 & 0,00 & 0,00 & 0,00 & 0,00 & 0,00 \\
\hline 21 Serviços & 0,00 & 0,00 & 0,00 & 0,00 & 0,00 & 0,00 & 0,00 \\
\hline Total & 20,87 & 21,28 & 23,50 & 31,49 & 31,37 & 33,91 & 37,66 \\
\hline
\end{tabular}

D20

Participação das Exportaçōes para o Resto do Mundo nas exportaçōes totais brasileiras - 1990 - 96

\begin{tabular}{|c|c|c|c|c|c|c|c|}
\hline Produtos & 1990 & 1991 & 1992 & 1993 & 1994 & 1995 & 1996 \\
\hline 1 Agropecuária & 86,89 & 82,25 & 93,36 & 92,99 & 94,96 & 93,48 & 92,62 \\
\hline 2 Mineração & 94,94 & 94,48 & 89,39 & 73,11 & 72,79 & 73,21 & 78,71 \\
\hline 3 Minerais não Metálicos & 94,19 & 94,19 & 93,59 & 91,45 & $91, \infty 9$ & 91,36 & 90,65 \\
\hline 4 Metalurgia & 92,16 & 88,00 & 84,81 & 81,95 & 82,25 & 82,97 & 82,67 \\
\hline 5 Mecânica e Material Elétriı & 83,76 & 79,99 & 78,32 & 73,82 & 73,76 & 71,84 & 68,25 \\
\hline 6 Material de Transporte & 88,92 & 64,03 & 64,01 & 55,70 & 59,53 & 57,36 & 51,54 \\
\hline 7 Madeira e Mobiliário & 78,88 & 90,96 & 95,99 & 94,23 & 94,20 & 96,13 & 94,96 \\
\hline 8 Papel e Papelão & 89,56 & 77,18 & 71,47 & $\mathfrak{3 , 8 8}$ & 70,47 & $\varpi, 62$ & 61,68 \\
\hline 9 Borracha & 76,25 & 64,57 & జ3,66 & 58,68 & 58,06 & 61,40 & 54,70 \\
\hline 10 Indústria Química & 76,38 & $\wp, 70$ & 74,78 & $๗, 44$ & 66,93 & 64,66 & 65,20 \\
\hline 11 Indústria Famnacêutica & 96,19 & 66,92 & 76,96 & $\varpi 9,68$ & 67,77 & 61,78 & 58,32 \\
\hline 12 Plásticos & 78,73 & $\circledast 8,57$ & 62,56 & 54,77 & 52,41 & 48,32 & 40,11 \\
\hline 13 Indústria Têxtil & 98,70 & 97,60 & 77,04 & $\mathfrak{3 , 7 4}$ & 68,28 & 68,52 & 55,90 \\
\hline 14 Vestuário & 98,35 & 96,64 & 77,22 & 73,46 & 73,56 & 72,21 & $\widetilde{63,66}$ \\
\hline 15 Calçados e Couros & 93,54 & 94,54 & 97,12 & 96,59 & 95,90 & 95,08 & 94,71 \\
\hline 16 Produtos Alimentares & 98,41 & 100,60 & 95,47 & 93,51 & 93,09 & 93,19 & 93,25 \\
\hline 17 Diversos & 85,03 & 72,87 & 92,47 & 82,87 & 89,31 & 87,60 & 68,29 \\
\hline 18 Serviços Industriais de U.| & 0,00 & 0,00 & 0,00 & 0,00 & 0,00 & 0,00 & 0,00 \\
\hline 19 Construção Civil & 0,00 & 0,00 & 0,00 & 0,00 & 0,00 & 0,00 & 0,00 \\
\hline 20 Transporte e M. Comércio & 0,00 & 0,00 & 0,00 & 0,00 & 0,00 & 0,00 & 0,00 \\
\hline 21 Serviços & 0,00 & 0,00 & 0,00 & 0,00 & 0,00 & 0,00 & 0,00 \\
\hline Total & 1510,89 & 1402,08 & 1388,22 & 1289,87 & 1304,97 & 1288,72 & 1215,22 \\
\hline
\end{tabular}


D21

Participação das Importações para a Argentina nas importações totais brasileiras - 1990 - 96

\begin{tabular}{lccccccc}
\hline \multicolumn{1}{c}{ Setores } & 1990 & 1991 & 1992 & 1993 & 1994 & 1995 & 1996 \\
\hline 1 Agropecuária & 38,19 & 38,64 & 48,04 & 49,49 & 43,76 & 42,70 & 44,37 \\
2 Mineração & 0,27 & 1,06 & 2,26 & 10,36 & 12,80 & 14,76 & 17,84 \\
3 Minerais não Metálicos & 25,08 & 24,63 & 2,19 & 2,77 & 3,17 & 3,81 & 3,00 \\
4 Metalurgia & 2,61 & 2,91 & 2,69 & 4,69 & 3,40 & 4,15 & 4,28 \\
5 Mecânica e Material Elétric & 26,87 & 33,99 & 25,83 & 0,74 & 1,15 & 1,65 & 1,00 \\
6 Material de Transporte & 2,81 & 5,03 & 10,60 & 22,65 & 19,70 & 16,99 & 30,21 \\
7 Madeira e Mobiliário & 20,18 & 9,34 & 3,86 & 2,50 & 4,66 & 7,71 & 15,55 \\
8 Papel e Papelão & 12,25 & 5,21 & 2,89 & 2,12 & 2,17 & 6,82 & 8,12 \\
9 Borracha & 2,75 & 2,48 & 2,61 & 4,85 & 6,69 & 7,55 & 7,21 \\
10 Indústria Química & 3,18 & 4,31 & 4,25 & 3,27 & 3,46 & 3,53 & 3,88 \\
11 Indústria Farmacêutica & 1,03 & 0,67 & 1,67 & 2,72 & 3,77 & 5,38 & 7,63 \\
12 Plásticos & 6,16 & 8,71 & 11,02 & 6,98 & 8,13 & 8,26 & 9,74 \\
13 Indústria Têxtil & 9,60 & 10,11 & 12,19 & 7,04 & 15,71 & 14,39 & 20,45 \\
14 Vestuário & 4,96 & 4,66 & 2,96 & 1,73 & 2,12 & 4,08 & 2,62 \\
15 Calçados e Couros & 18,71 & 54,46 & 48,80 & 36,77 & 34,41 & 32,90 & 33,47 \\
16 Produtos Alimentares & 17,61 & 15,54 & 12,57 & 13,01 & 17,62 & 15,83 & 17,97 \\
17 Diversos & 48,46 & 39,34 & 10,64 & 3,99 & 2,68 & 3,87 & 4,39 \\
18 Serviços Industriais de U.I & 0,00 & 0,00 & 0,00 & 0,00 & 0,00 & 0,00 & 0,00 \\
19 Construção Civil & 0,00 & 0,00 & 0,00 & 0,00 & 0,00 & 0,00 & 0,00 \\
20 Transporte e M. Comércio & 0,00 & 0,00 & 0,00 & 0,00 & 0,00 & 0,00 & 0,00 \\
21 Serviços & 0,00 & 0,00 & 0,00 & 0,00 & 0,00 & 0,00 & 0,00 \\
Total & 7,35 & 8,29 & 8,52 & 10,89 & 11,07 & 10,97 & 12,72 \\
\hline
\end{tabular}

D22

Participação das Importações para o Paraguai nas importaçōes totais brasileiras - 1990 - 96

\begin{tabular}{|c|c|c|c|c|c|c|c|}
\hline Setores & 1990 & 1991 & 1992 & 1993 & 1994 & 1995 & 1996 \\
\hline 1 Agropecuária & 8,38 & 2,22 & 1,09 & 0,93 & 3,80 & 5,41 & 5,23 \\
\hline 2 Mineração & 0,00 & 0,00 & 0,00 & 0,00 & 0,00 & 0,00 & 0,00 \\
\hline 3 Minerais não Metálicos & 4,67 & 4,58 & 0,00 & 0,00 & 0,08 & 0,02 & 0,01 \\
\hline 4 Metalurgia & 0,01 & 0,00 & 0,00 & 0,02 & 0,13 & 0,03 & 0,06 \\
\hline 5 Mecânica e Material Elétric & 0,24 & 0,16 & 0,04 & 0,00 & 0,00 & 0,00 & 0,01 \\
\hline 6 Material de Transporte & 0,03 & 0,01 & 0,00 & 0,00 & 0,00 & 0,00 & 0,00 \\
\hline 7 Madeira e Mobiliário & 37,28 & 23,93 & 28,40 & 24,20 & 17,57 & 8,70 & 7,36 \\
\hline 8 Papel e Papelão & 0,09 & 0,12 & 0,15 & 0,12 & 0,12 & 0,15 & 0,07 \\
\hline 9 Borracha & 0,01 & 0,00 & 0,00 & 0,00 & 0,00 & 0,02 & 0,04 \\
\hline 10 Indústria Química & 0,15 & 0,05 & 0,04 & 0,03 & 0,02 & 0,05 & 0,04 \\
\hline 11 Indústria Farmacêutica & 0,01 & 0,00 & 2,23 & 7,23 & 0,58 & 0,33 & 0,12 \\
\hline 12 Plásticos & 0,00 & 0,00 & 0,00 & 0,00 & 0,00 & 0,00 & 0,01 \\
\hline 13 Indústria Têxtil & 24,79 & 23,78 & 22,70 & 13,93 & 11,40 & 8,86 & 9,11 \\
\hline 14 Vestuário & 11,65 & 11,87 & 2,93 & 2,00 & 1,81 & 1,05 & 1,22 \\
\hline 15 Calçados e Couros & 0,54 & 0,32 & 0,93 & 4,33 & 3,29 & 0,94 & 0,26 \\
\hline 16 Produtos Alimentares & 0,38 & 1,94 & 6,48 & 4,75 & 3,82 & 3,65 & 4,77 \\
\hline 17 Diversos & 0,00 & 0,03 & 0,13 & 0,03 & 0,00 & 0,00 & 0,02 \\
\hline 18 Serviços Industriais de U.I & 0,00 & 0,00 & 0,00 & 0,00 & 0,00 & 0,00 & 0,00 \\
\hline 19 Construcão Civil & 0,00 & 0,00 & 0,00 & 0,00 & 0,00 & 0,00 & 0,00 \\
\hline 20 Transporte e M. Comércio & 0,00 & 0,00 & 0,00 & 0,00 & 0,00 & 0,00 & 0,00 \\
\hline 21 Serviços & 0,00 & 0,00 & 0,00 & 0,00 & 0,00 & 0,00 & 0,00 \\
\hline Total & 1,64 & 1,11 & 0,96 & 1,10 & 1,07 & 1,03 & 1,03 \\
\hline
\end{tabular}


D23

Participação das Importaçōes para o Uruguai nas importaçōes totais brasileiras - 1990 - 96

\begin{tabular}{|c|c|c|c|c|c|c|c|}
\hline Setores & 1990 & 1991 & 1992 & 1993 & 1994 & 1995 & 1996 \\
\hline 1 Agropecuária & 15,46 & 12,93 & 8.49 & 10,37 & 11,17 & 9,18 & 11.63 \\
\hline 2 Mineração & 0,00 & 0,00 & 0.00 & 0,00 & 0,00 & 0,04 & 0,22 \\
\hline 3 Minerais nāo Metálicos & 0,85 & 0,83 & 0,84 & 1,53 & 1,41 & 1,06 & 0.94 \\
\hline 4 Metalurgia & 0,22 & 0,18 & 0,12 & 0,19 & 0,17 & 0,19 & 0,22 \\
\hline 5 Mecánica e Material Elétric & 6,96 & 6,10 & 3,10 & 0,06 & 0,10 & 0,11 & 0.08 \\
\hline 6 Material de Transporte & 0,06 & 0,07 & 0,14 & 0,36 & 0,77 & 0,35 & 0,82 \\
\hline 7 Madeira e Mobiliário & 2,16 & 1,07 & 0,50 & 0,38 & 4,25 & 4,17 & 3.51 \\
\hline 8 Papel e Papelão & 0,99 & 1,05 & 1,88 & 0,25 & 0,11 & 0,38 & 1,78 \\
\hline 9 Borracha & 8,56 & 4,55 & 4,85 & 5,72 & 5,23 & 3,98 & 3,60 \\
\hline 10 Indústria Química & 2,46 & 1,56 & 1.00 & 0,69 & 0,52 & 0,44 & 0,39 \\
\hline 11 Indú stria Farmacêutica & 3,28 & 5,72 & 3,74 & 1,82 & 1,71 & 2,77 & 2.17 \\
\hline 12 Plásticos & 3,84 & 3,38 & 4,56 & 3,33 & 3,23 & 3,50 & 3,27 \\
\hline 13 Indústria Têxtil & 5,67 & 5,10 & 5,06 & 2,48 & 2,92 & 2,63 & 2.24 \\
\hline 14 Vestuário & 66,07 & 64,92 & 29,14 & 23,61 & 16,73 & 10,34 & 11,79 \\
\hline 15 Calçados e Couros & 51,72 & 15,51 & 8.39 & 8,75 & 5,26 & 3,76 & 3.26 \\
\hline 16 Produtos Alimentares & 3,42 & 2,28 & 2.48 & 1,79 & 2,33 & 2,20 & 2,58 \\
\hline 17 Diversos & 4,53 & 1,57 & 11.32 & 2,74 & 1,59 & 0,59 & 0.46 \\
\hline 18 Serviços Industriais de U.I & 0,00 & 0,00 & 0,00 & 0,00 & 0,00 & 0,00 & 0.00 \\
\hline 19 Construção Civil & 0,00 & 0,00 & 0,00 & 0,00 & 0,00 & 0,00 & 0.00 \\
\hline 20 Transporte e M. Comércio & 0,00 & 0,00 & 0,00 & 0,00 & 0,00 & 0,00 & 0,00 \\
\hline 21 Serviços & 0,00 & 0,00 & 0,00 & 0,00 & 0,00 & 0,00 & 0,00 \\
\hline Total & 2,87 & 2,08 & 1.48 & 1,54 & 1,72 & 1,48 & 1,74 \\
\hline
\end{tabular}

D24

Participação das Importaçōes para o Chile nas importaçōes totais brasileiras - 1990 - 96

\begin{tabular}{|c|c|c|c|c|c|c|c|}
\hline Setores & 1990 & 1991 & 1992 & 1993 & 1994 & 1995 & 1996 \\
\hline 1 Agropecuária & 6,49 & 4,37 & 2,47 & 2,92 & 2,47 & 3,79 & 3,73 \\
\hline 2 Mineração & 0,00 & 0,00 & 0,00 & 0,00 & 0,00 & 0,02 & 0,00 \\
\hline 3 Minerais não Metálicos & 2,12 & 2,08 & 35,17 & 32,00 & 27,15 & 32,02 & 23,57 \\
\hline 4 Metalurgia & 3,71 & 3,56 & 2.92 & 2,68 & 2,24 & 3,10 & 2,24 \\
\hline 5 Mecânica e Material Elétric & 2,02 & 1,21 & 0,14 & 0,01 & 0,01 & 0,03 & 0,02 \\
\hline 6 Material de Transporte & 0,00 & 0,00 & 0,01 & 0,04 & 0,01 & 0,02 & 0.03 \\
\hline 7 Madeira e Mobiliário & 23,11 & 28,49 & 17,68 & 14,43 & 14,45 & 13,23 & 7,29 \\
\hline 8 Papel e Papelão & 9,65 & 14,14 & 4,35 & 5,29 & 5,32 & 7,65 & 7,50 \\
\hline 9 Borracha & 0,30 & 0,12 & 0,32 & 0,03 & 0,22 & 0,52 & 0,10 \\
\hline 10 Indústria Química & 1,80 & 1,60 & 1,35 & 1,12 & 2,68 & 2,09 & 1,54 \\
\hline 11 Indústria Farmacêutica & 7,93 & 7,32 & 0,64 & 0,58 & 0,36 & 0,36 & 0,20 \\
\hline 12 Plásticos & 0,03 & 0,05 & 0,07 & 0,21 & 0,14 & 0,12 & 0,11 \\
\hline 13 Indústria Têxtil & 1,69 & 0,79 & 0,33 & 0,32 & 0,44 & 0,70 & 0,78 \\
\hline 14 Vestuário & 0,04 & 0,90 & 0,08 & 0,13 & 0,19 & 0,46 & 0,90 \\
\hline 15 Calçados e Couros & 0,74 & 2,16 & 0,44 & 0,35 & 0,23 & 0,10 & 0,22 \\
\hline 16 Produtos Alimentares & 4,18 & 4,29 & 8,74 & 5,30 & 3,76 & 3,44 & 3,36 \\
\hline 17 Diversos & 0,01 & 0,04 & 0,00 & 0,02 & 0,17 & 0,09 & 0,12 \\
\hline 18 Serviços Industriais de U.I & 0,00 & 0,00 & 0,00 & 0,00 & 0,00 & 0,00 & 0,00 \\
\hline 19 Construção Civil & 0,00 & 0,00 & 0,00 & 0,00 & 0,00 & 0,00 & 0,00 \\
\hline 20 Transporte e M. Comércio & 0,00 & 0,00 & 0,00 & 0,00 & 0,00 & 0,00 & 0,00 \\
\hline 21 Serviços & 0,00 & 0,00 & 0,00 & 0,00 & 0,00 & 0,00 & 0.00 \\
\hline Total & 1,69 & 1,76 & 2,35 & 1,75 & 1,79 & 2,19 & 1.72 \\
\hline
\end{tabular}


D25

Participação das Importaçōes para a Bolívia nas importaçōes totais brasileiras - 1990 - 96

\begin{tabular}{llllllll}
\hline \multicolumn{1}{c}{ Setores } & 1990 & 1991 & 1992 & 1993 & 1994 & 1995 & 1996 \\
\hline 1 Agropecuáría & 0,79 & 0,23 & 0,27 & 0,04 & 0,13 & 0,09 & 0,67 \\
2 Mineração & 0,00 & 0,00 & 0,00 & 0,00 & 0,00 & 0,00 & 0,00 \\
3 Minerais não Metálicos & 2,03 & 1,56 & 0,70 & 1,67 & 1,67 & 1,07 & 0,59 \\
4 Metalurgia & 0,01 & 0,00 & 0,00 & 0,01 & 0,00 & 0,00 & 0,00 \\
5 Mecânica e Material Elétric & 0,00 & 0,04 & 0,01 & 0,00 & 0,00 & 0,00 & 0,00 \\
6 Material de Transporte & 0,00 & 0,00 & 0,00 & 0,00 & 0,00 & 0,00 & 0,00 \\
7 Madeira e Mobiliário & 5,30 & 2,55 & 2,98 & 1,25 & 1,08 & 0,49 & 0,53 \\
8 Papel e Papelão & 0,00 & 0,00 & 0,03 & 0,03 & 0,01 & 0,01 & 0,00 \\
9 Borracha & 0,46 & 0,15 & 0,02 & 0,00 & 0,01 & 0,01 & 0,00 \\
10 Indústria Quimica & 0,01 & 0,00 & 0,02 & 0,02 & 0,00 & 0,00 & 0,00 \\
11 Indústria Farmacêutica & 0,00 & 0,00 & 0,00 & 0,00 & 0,00 & 0,00 & 0,00 \\
12 Plásticos & 0,00 & 0,00 & 0,01 & 0,00 & 0,00 & 0,00 & 0,00 \\
13 Indústria Têxtil & 0,54 & 1,07 & 0,28 & 0,07 & 0,14 & 0,09 & 0,73 \\
14 Vestuário & 0,72 & 0,00 & 0,44 & 1,55 & 0,82 & 0,25 & 1,07 \\
15 Calçados e Couros & 1,17 & 0,47 & 0,00 & 1,01 & 0,31 & 0,20 & 0,13 \\
16 Produtos Alimentares & 0,22 & 0,28 & 0,62 & 0,60 & 0,40 & 0,25 & 0,27 \\
17 Diversos & 0,00 & 0,00 & 0,00 & 0,01 & 0,01 & 0,00 & 0,00 \\
18 Serviços Industriais de U.I & 0,00 & 0,00 & 0,00 & 0,00 & 0,00 & 0,00 & 0,00 \\
19 Construção Civil & 0,00 & 0,00 & 0,00 & 0,00 & 0,00 & 0,00 & 0,00 \\
20 Transporte e M. Comércio & 0,00 & 0,00 & 0,00 & 0,00 & 0,00 & 0,00 & 0,00 \\
21 Serviços & 0,00 & 0,00 & 0,00 & 0,00 & 0,00 & 0,00 & 0,00 \\
Total & 0,18 & 0,13 & 0,08 & 0,08 & 0,07 & 0,05 & 0,12 \\
\hline
\end{tabular}

D26

Participação das Importaçōes para o Resto do Mundo nas importaçōes totais brasileiras - 1990 - 96

\begin{tabular}{lccccccc}
\hline \multicolumn{1}{c}{ Setores } & 1990 & 1991 & 1992 & 1993 & 1994 & 1995 & 1996 \\
\hline 1 Agropecuária & 30,69 & 41,60 & 39,63 & 36,26 & 38,67 & 38,80 & 34,37 \\
2 Mineração & 99,73 & 98,94 & 97,73 & 89,64 & 87,20 & 85,19 & 81,94 \\
3 Minerais não Metálicos & 65,25 & 66,32 & 61,09 & 62,03 & 66,52 & 61,77 & 71,89 \\
4 Metalurgia & 93,52 & 92,30 & 94,27 & 92,42 & 94,05 & 92,53 & 93,20 \\
5 Mecânica e Material Elétric & 63,90 & 58,49 & 70,88 & 99,18 & 98,74 & 98,22 & 98,89 \\
6 Material de Transporte & 97,11 & 94,89 & 89,26 & 76,94 & 79,52 & 82,64 & 68,94 \\
7 Madeira e Mobiliário & 11,96 & 34,63 & 46,58 & 57,25 & 57,98 & 65,76 & 65,76 \\
8 Papel e Papelão & 77,02 & 79,48 & 90,70 & 92,20 & 92,26 & 84,99 & 82,52 \\
9 Borracha & 87,92 & 92,70 & 92,19 & 89,40 & 87,86 & 87,94 & 89,05 \\
10 Indústria Quimica & 92,40 & 92,47 & 93,34 & 94,88 & 93,31 & 93,89 & 94,14 \\
11 Indústria Farmacêutica & 87,75 & 86,28 & 91,73 & 87,65 & 93,58 & 91,17 & 89,88 \\
12 Plásticos & 89,97 & 87,86 & 84,35 & 89,47 & 88,51 & 88,12 & 86,87 \\
13 Indústria Têxtil & 57,69 & 59,15 & 59,44 & 76,16 & 69,39 & 73,41 & 66,70 \\
14 Vestuário & 16,56 & 17,65 & 64,46 & 70,99 & 78,32 & 83,42 & 82,39 \\
15 Calçados e Couros & 27,12 & 27,07 & 41,44 & 48,79 & 56,51 & 62,17 & 62,66 \\
16 Produtos Alimentares & 74,20 & 75,67 & 69,12 & 74,54 & 72,07 & 74,52 & 71,05 \\
17 Diversos & 47,00 & 59,02 & 77,91 & 93,21 & 95,55 & 95,44 & 95,01 \\
18 Serviços Industriais de U.I & 0,00 & 0,00 & 0,00 & 0,00 & 0,00 & 0,00 & 0,00 \\
19 Construção Civil & 0,00 & 0,00 & 0,00 & 0,00 & 0,00 & 0,00 & 0,00 \\
20 Transporte e M. Comércio & 0,00 & 0,00 & 0,00 & 0,00 & 0,00 & 0,00 & 0,00 \\
21 Serviços & 0,00 & 0,00 & 0,00 & 0,00 & 0,00 & 0,00 & 0,00 \\
Total & 86,27 & 86,64 & 86,61 & 84,64 & 84,29 & 84,28 & 82,67 \\
\hline
\end{tabular}

